
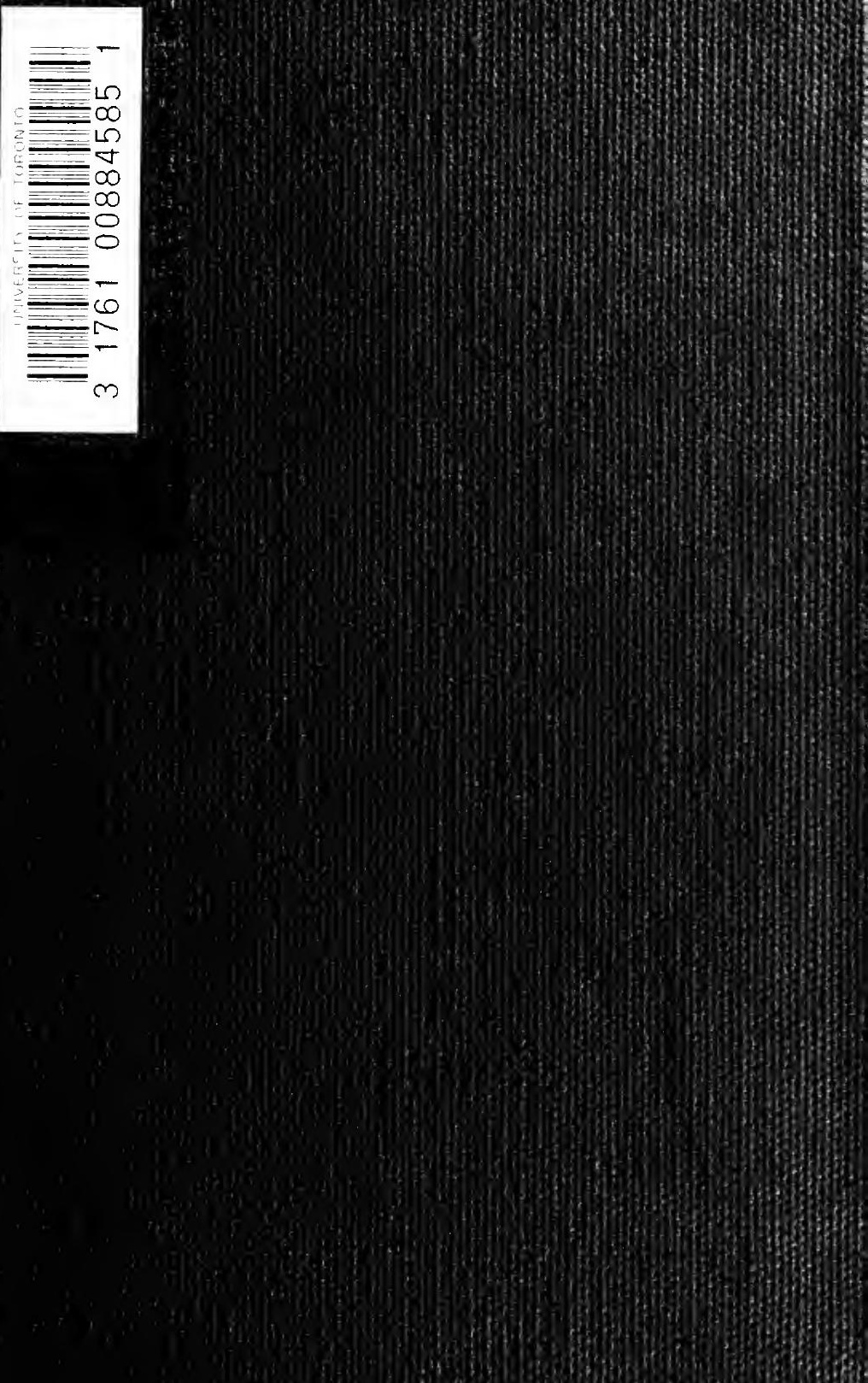
Digitized by the Internet Archive in 2007 with funding from Microsoft Corporation 


TRANSLATIONS OF CHRISTIAN LITERATURE SERIES $\mathrm{V}$

LIVES OF THE CELTIC SAINTS

EnTEE, BY ELEANOR IIULL

ST. MALACHY OF ARMAGH

(MÁEL MAEDǴC UA MORGAKR)

IIS LIFE IND (THER MOUMENTS RELATING TU IIM, COMHOSED IYY ST. ISENARL UF CLARVAUX 



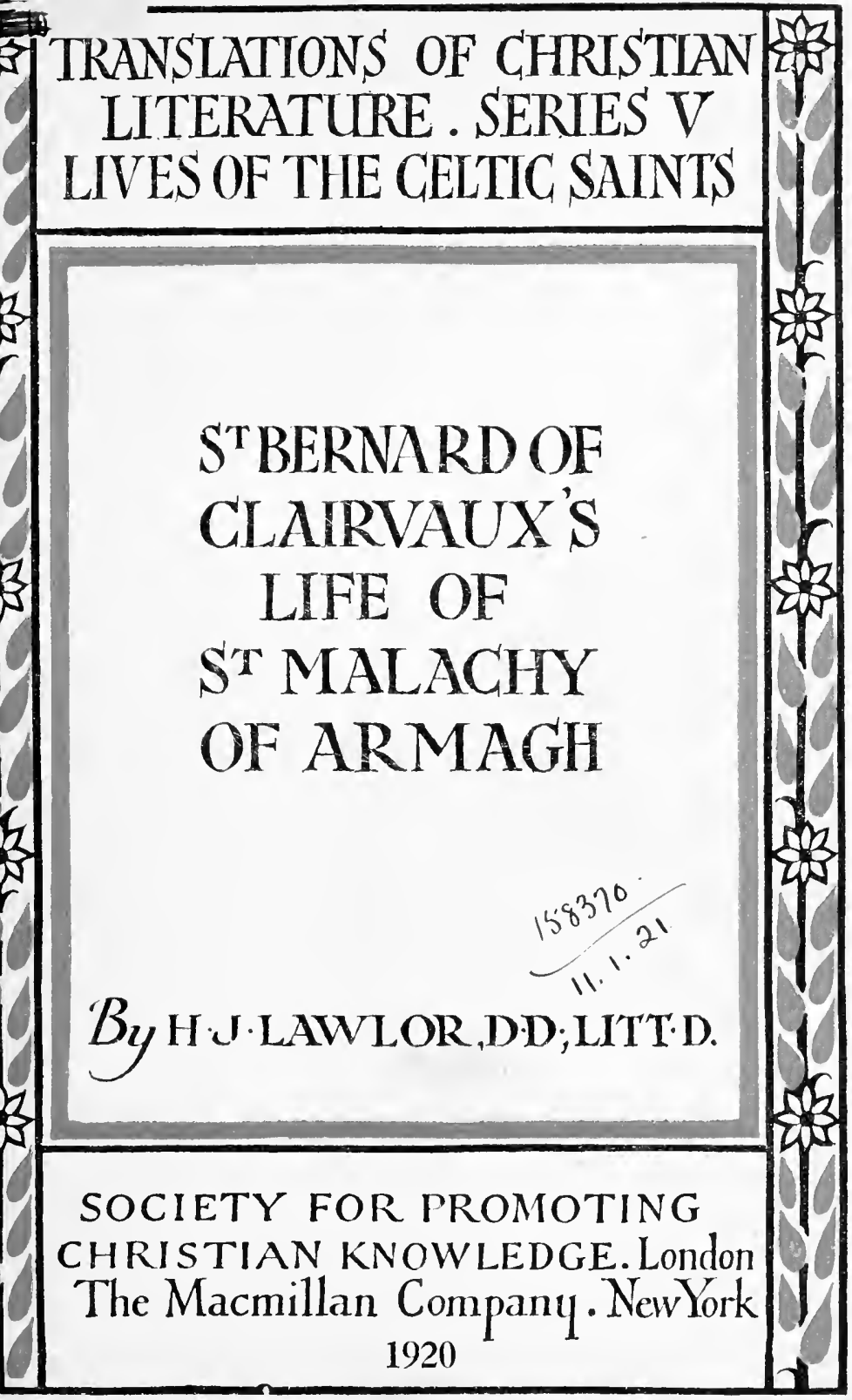




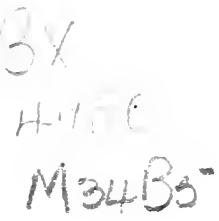

p'rinted in Great Britain by Richard Ciay \& Sons, limited, UKUNSWICK ST., STAMHORDST., S.k. I, AND BUNGAY, SUFFOLK. 


\section{CONTENTS}

PRINCIPAT AUTIORITIES REFERRED TO • • . vii

NAMES OF IRISH PERSONS AND PIACES . . . $\mathrm{x}$

INTRODUCTION . . . . . . . . . . .

IIFE OF ST. MALACHY . . . . . I

LETTERS OF ST. BERNARD . . . . I3I

SERMONS OF ST. TERNARD ON THE PASSING OF MALACHY . . . . . . . . I.fI

ADDITIONAL NOTES :-

A.-ST. DERNARD'S DESCRIPTION OF THE STATE OF THE IRISH CHURCH . . . . . I6I

B.-THE HEREDITARY SUCCESSION OF THE COARDS OF PATRICK . . . . . . . . I . . . . .

C.-MALACHY'S CONTEST With Nial, . . I67 APPENDIX . . . . . . .

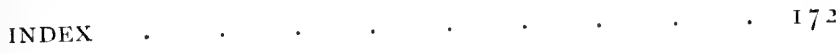





\section{PRINCIPAL AUTHORITIES REFERRED TO}

A. T.C.D. MS. F. 4,6, containing the Vita S. Malachiae and a portion of Sermo ii. imbedded therein. Cent. xiii.; copied from a much earlier exemplar.

A.SS. Acta Sanctormm.

A.F.M. Annals of the Kingtom of Ireland by the Four Masters, el. J: O'Donovan, I $85 \mathrm{I}$.

A.I. Annals of Inisfallen, in O'Conor, Rerum ITlurnicarmm

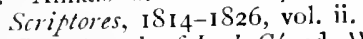

A.L.C. Annals of Loch $C e^{\prime}$, ed. W. M. I]ennessy (R.S.), i $S_{7}$ I.

A.T. Annals of Tigernach (so called: see J. MacNeill in Eriu, vii. 30), ed. W. Stokes, in hezue Celtique, xvi.-xvii.

A.U. Amnals of Ulster, otherwise Ammals of Senat, ed. W. M. llennessy and B. MacCarthy, I $\$ 87-1901$.

Adamnan. The Life of St. Columba, written by Adamnan, ed. WV. keeves (Irish Archeological and Celtic Society), $18_{57}$

Archdall. M. Arehdall, Monasticon Hibernicum, I 786 : the earlier part ed. ly P. F. Moran, I 873 .

C.M.A. Chartularies of St. Mary's Abbiy, Dublin, ed. J. T. Gilbert (R.S.), I $S S_{4}$.

Cant. S. Bernardi Sermones in Cantica, in P.L. clxxxiii. $779 \mathrm{ff}$. (I 879 ) : English Translation by $\mathrm{S}$. J. Eales, The Life am Horks of Si. Bernard, vol. iv., I 896.

Colgan, A.S.t1. J. Colgan, Acta Sanctorum Hiberniat, Lovanii, i645, tom. i.

D.A.I. The Dublin Annals of Inisfallen, Royal Irish Academy MS. 23, F. 9.

De Cons. S. Bernardi De Consideratione Libri $I^{\prime}$., in I.L. elxxxii. 727 ff. (IS79): English Translation by G. Lewis, y goS.

De Dil. S. Bermardi De Diligendo Deo in P.L. clxxxii. $973 \mathrm{ff}$. ( I 879). English Translations by M. C. and C. I'atmore, second exl., I $8 S_{4}$, and E. G. Gardner, I9I6.

Dugdale. W. Dugdale, Monasticon Anslicanum, cd. J. Caley, 1$].$ Ellis and B. Bandinel, $1817-30$.

Eadmer. Eadmeri ITistoria Novorm in Anslia, ed. M. Rule (I.S.), $18 S_{4}$.

Ef. S. Pernardi Epistola in I.L. elxxxii. $67 \mathrm{ff} .(1879)$ : English Translation in S. J. Eales, The Life and Horks of St. Bernard, vols. i.-iii. $\left.-1 S S_{9} 1896\right)$. 


\section{viii PRINCIPAL AUTHORITIES REFERRED TO}

Giraldus, Expus:; Gest.: Top. Giraldi Cambrensis Opera, ed. J.S. Brewer, J. I. Dimock and G. F. Warner (K.S.), 1S6I-IgoI. Expusmatio Hibernica, vol. v. 1. 207 ff. ; De líbus a se Gestis, vol. i. p. I ff.; Tofosmatia Hibernica, vol. v. p. I ff.

Gorman. The Martyrolosy of Gorman, cu. W. Stokes (Jlenry

Bradshaw Socicty), ISig5.

Gougand. L. Gougand, Les Chrétientís Celtivues, InI I.

(iwynn. 'The Book of Armagh, ed. J. Gwynn, igr3.

J.R.S.A.I. Jowmal of the Royal Society of Antiquries of Treland: references to volumes according to the consecutive numbering.

Jaffé. K'esesta Pontifucum Romanorum, cd. P. Jaffé, IS5I.

John of IJexham. Historia Johamis Prioris Magustaldensis Ealesiae, in Symeonis Monahi Dunelmensis Opera Omnia, cr. T. Amold (R.S.), ii. (1 $\left.S_{5}\right), 2 S_{4}$ ff.

k. Corlex Kilkenniensis; Marsh's Library, Dulılin, MS. Z. I.5, containing the lita $S$. Malachiat. Cent. xv.

Keating. G. Keating, Ifistory of Krland, er. D. Comyn and P. S.

Dinneen (Irish Texts Society), I902-I914.

1.A.J. County Louth Archaolesical Joumal.

I.. L. Lealhar Breac, Royal Irish Academy MS. (Facsimile ed. $S_{76 .)}$

Lanigan. J. Lanigan, An Ecclesiastical History of Ireland. . . to the Begiming of the Thintenth Century, IS29.

M.G.Il. Monumenta Germaniae Historia.

Mansi. Sarorm Conciliorm nova et amplissima Collectio, ed. J. D. Mansi, I $759^{-1} 798$.

O.C.C. The Siook of Obits and Martyology of the Cathedral Chwrh of the FHoly, Trinity, commonly called Christ Church, Dublin, ed. J. C. Crosthwaite and J. H. Todd (Irish Archeological Society), 1 S $_{4}$.

Oengus. The Martyrology of Oengus the Culdee, ed. W. Stokes (Henry lBradshaw Society), I905. ('Janlon. J. O'Ianlon, The' Life' of Saint Malachy O'Morgair,
IS59. O'Ilanlon, Saints. J. O'IJanlon, Lizes of the Trish Saints, vols.
i.-ix., IS75-I90I. I. L. Patrologive Cursus Completus, Series Latina, ed. J. P.
Migne.

Petrie. G. I'etrie, The Ecclesiastical Arshitccture of Ireland. . . comprising an Essay on the Origin and Uses of the Lounit
Towers of Irclind, $1 S_{45}$.

Plummer. Iritae Sanctormm Hiberniae, ed. C. Plummer, rgro. l'lummer, Bede. Fenterabilis Bacdac Opera Historica, ed. C.
Plummer, IS96.

R.I.A. Procedings of the Royal Irish Academy, Archeology, Linguistic and Literature. References to volumes according to the consecutive numbering.

R.I.A. Trans. Transactions of the Royal Trish Acalemy.

R.1 ..II. Revue des Questions Historiques. 
R.T.A. Kegisicr of the Abhy of St. Thomas, Iublin, ed. J. T. Gilbert (R.S.), I $\$ 89$.

Reeves. W. Reeves, Ecclesiastical Antiquities of Down, Conn." and Dromore, IS.47.

Reeves, Churches. W. Reeves, Ancient Churches of Armagh, i860.

Richard of I Iexham. Historia Ritarli frioris Mutgustaldensis, in Chronicles of Stephen, etc., ed. IIowlett (K.S.), iii. (ISS6), I $37 \mathrm{ff}$.

Theiner. A. Theiner, Vetera Monumenta Hibrmorum et Siotorum, 1216-15.47, Romae, IS64.

Todd. J. II. Todd, St. Patrick Apostle of Trelend, I864.

Trias. J. Colgan, Triadis Thaumaturgae seu divorum Patricii, Columbe et Brigidae Acta, Lovanii, 1647 (vol. ii. of his Acta Sanctornm Hiherniae).

Trip. W. Stokes, The Tripartite Life of Patrick wilh other Documents relating to that Saint, eil. W. Stokes (R.S.), ISS7.

Tundale. Visio Tnusdali lateinisch und alldeutsch, ed. A. Wagner, I $\$ S 2$.

Ussher. J. Ussher, Veterum Efistolarmm Hilinicarmm Sylloge, in Works, ed. C. K. Elrington, $1 S_{47}-1 S 6_{4}$, vol. iv., $\mathrm{PP} \cdot 3^{\mathrm{S}} 3 \mathrm{ft}$.

V.P. S. Firnardi Fita Prima, in P.I. clexxv., $225 \mathrm{ff}$.

Vacandard. Vie de Saint Bernard Abhé de Clairzaux par l'Abué E. Vacandard, 4e édition, I9ro. 


\section{NAMES OF IRISH PERSONS AND PLACES}

\begin{tabular}{|c|c|c|}
\hline $\begin{array}{l}\text { Form used in this } \\
\text { volume. }\end{array}$ & $\begin{array}{l}\text { Forn used by } \\
\text { St. Iiernard. }\end{array}$ & Irish Form. \\
\hline $\begin{array}{l}\text { Antrim } \\
\text { Armagh }\end{array}$ & $\begin{array}{l}\text { (Oenthrel, } \\
\text { Ardmacha }\end{array}$ & $\begin{array}{l}\text { Oentreb } \\
\text { Ard Macha }\end{array}$ \\
\hline liangor & Benchor & Bennchor \\
\hline $\begin{array}{l}\text { Cashel } \\
\text { Catholicus } \\
\text { Cellach } \\
\text { Christian } \\
\text { Coleraine } \\
\text { Colnmbanus } \\
\text { Comgall } \\
\text { Connor } \\
\text { Conor } \\
\text { Cork }\end{array}$ & $\begin{array}{l}\text { Caselensis } \\
\text { Calholicus } \\
\text { Celsus } \\
\text { Christianus } \\
\text { Culratim } \\
\text { Columbunus } \\
\text { Congellus } \\
\text { Connereth } \\
\text { Corcagia }\end{array}$ & $\begin{array}{l}\text { Caisel } \\
\text { Catlac } \\
\text { Cellach } \\
\text { Gilla Crist } \\
\text { Cúl Rathin } \\
\text { Collumbán } \\
\text { Comgall } \\
\text { Coindire } \\
\text { Conchobar } \\
\text { Corcach }\end{array}$ \\
\hline $\begin{array}{l}\text { Jermot } \\
\text { l Derry } \\
\text { l hesmond } \\
\text { Donnell } \\
\text { Donomgh } \\
\text { Down }\end{array}$ & $\begin{array}{l}\text { 1)iamicius } \\
\text { Mumonia australis }\end{array}$ & $\begin{array}{l}\text { Diarmait } \\
\text { Daire } \\
\text { Desmuma } \\
\text { Domnall } \\
\text { f Donnchad } \\
\text { t Donngus } \\
\text { Dón dit Lethglas }\end{array}$ \\
\hline Edan & Edanus & Aellh \\
\hline Faughart & Fochart & Fochart \\
\hline $\begin{array}{l}\text { Cielasius } \\
\text { Ciillert }\end{array}$ & $\begin{array}{l}\text { Gelasius } \\
\text { Gillelıertus }\end{array}$ & $\begin{array}{l}\text { Gilla meic Liag } \\
\text { Gilla espuig }\end{array}$ \\
\hline $\begin{array}{l}\text { Imar } \\
\text { Inispatriele } \\
\text { Iveragh }\end{array}$ & $\begin{array}{l}\text { Imaru } \\
\text { Ibracensis }\end{array}$ & $\begin{array}{l}\text { Imar } \\
\text { Inis l'átraic } \\
\text { Ui láthacl }\end{array}$ \\
\hline
\end{tabular}


NAMES OF IRISH PERSONS AND PLACES xi

Form used in this volume.

Leinster

Limerick

Lismore

Lugadh

NaeCarthy

Maclisa )

Malchus i

Nalachy

Noriarty

Munster

N urrough

Nurtough

Nehemiah

Niall

\section{O'Boyle \\ G'Brien \\ O'Carroll \\ $\mathrm{O}^{\circ}$ Conor \\ O'llagan \\ O'llanraty \\ O'Hanley \\ O'kiclly \\ O'Loughlin \\ Oriel \\ O'korke}

Patrick

Rory

Sanl

Shalvey

Teague

Thomond

Turlough

Ulaid

Usnagh

Waterford

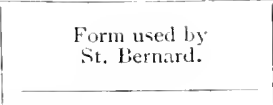

Laginia

Lesmore

Luanus

Malchus

Malachias

Mumonia

Nauricius

Nehemias

Nigrellus

l'atricias

$\left\{\begin{array}{l}\text { Saballum } \\ \text { Saballinum }\end{array}\right\}$

Ulyolia
Irish Form.

Laişin

Luimneach

Lis Mór

f Lugaid

(Molua

Mac (meic) Carthaig

Mael Ísa

Máel Máelóc

Ua Muirchertaig

II uma

Nurchadh

Muirchertach

Gilla na Naem

Niall

Ua liaigill

Ua litiain

Ua Cerlaill

Ua Conchobair

Ua hAedacain

Ua hIndrechtaig

Ua hingli

Ua Cellaig

$\mathrm{Ua}$ J ochlainn

Oirgialla

Ua liuarc

I'átraic

Ruaidhıi

Salıal I'hátraic

Ua Selbaigs

Tarling

Tuatlimuma

Toirclellach

Itlaicl

Uisnech

lort Láirge 


\section{INTRODUCTION}

THE main purpose of this Introduction is to give an account of a movement which changed the whole face of the Irish Church, and to the advancement of which St. Malachy devoted his life. In default of a better word we may call the movement a Reformation, though it might perhaps be more accurately described as an ecclesiastical revolution. Without some knowledge of its aims and progress it is impossible to assign to Malachy his true place in the history of his native country.

That such a movement actually took place in the twelfth century is beyond doubt. From about the year I 200 on it is certain that the organization of the Church of Ireland was similar to that of the other Churches of western Christendom. The country was divided into dioceses; and each diocese had a bishop as its ruler, and a Cathedral Church in which the bishop's stool was placed. The Cathedral Church, moreover, had a chapter of clergy, regular or secular, who performed important functions in the diocese. But up to the end of the eleventh century all these things were unknown among the Irish. The constitution of the Church was then of an entirely different type, one that had no exact parallel elsewhere. The passage from the older to the newer organization must have taken place in the twelfth century. During that century, therefore, there was a Reformation in the Irish Church, however little we may know of its causes or its process. But this Reformation xii 
was no mere re-modelling of the hierarchy. It can be shown that it imposed on the nembers of the Church a new standard of sexual morality; if we believe contemporary writers, it restored to their proper place such rites as Confession, Confirmation and Matrimony; it substituted for the offices of divine service previously in use those of the Roman Church; it introduced the custom of paying tithes; it established in Ireland the monastic orders of Latin Christendom ${ }^{1}$; and it may have produced changes in other directions. ${ }^{2}$ But I propose to confine myself to the change in the constitution of the Church, which was its most striking feature. The subject, even thus narrowed, will give us more than can be satisfactorily treated in a few pages.

First, I must emphasize the assertion made a moment ago that the constitution of the Irish Church in the eleventh century was sui seneris. Let us begin by reminding ourselves what it was from the sixth to the eighth century. It was then esscntially monastic in character. The rulers of the Church were the abbots of the monasteries, commonly known as the coarbs or successors of their founders. These abbots were sometimes bishops; but whether they were bishops or of lower rank in the ministry, their authority was inherent in their office of coarb. At this period bishops were numerous-more numerous than in later medieval or modern times; and certain functions were reserved for bishops, for example, ordination. No ecclesiastic, of whatever status, could perform such functions, unless be was of the episcopal order. But no bishop, as such, had jurisdiction. The bishops were often subordinate

1 See Life, $\$$ 6 (end), 7, 16, 17, 39 with notes, and Additional Note A.

${ }^{2} E . g$. in the doctrine of the Eucharist and of Baptism. Sce Lifi, $\$ 57$, and Lanfranc's letter to Donnell in Ussher, $495 ; P . L$, cl. 532 . 
officers in monasteries, reverenced because of their office, but executing their special functions at the command of the abbots. Somctimes a bishop was attached to a single tribe. Sometimes a group of bishops-often seven in number-dwelt together in one place. But in no case, I repeat, had they jurisdiction. Thus ecclesiastical authority was vested in the abbots. The episcopate was bestowed on certain individuals as a personal distinction. Thus the bishops, if they were not also abbots, had only such influence on the affairs of the Church as their sanctity, or their learning, might give them.

It may surprise some that so anomalous a system of government should have persisted as late as the eleventh century, in other words for a period of over 500 years. But we must take account of the Danish-or as we should rather call it, the Norse-invasion of Ireland. Ianish ships first appeared off the Irish coasts about the year soo. From that time for two centuries Ireland was to a large extent cut off from intercourse with the rest of Europe. The aim of the northern hordes, as it seems, was not mere pillage, but the extinction of Christianity. Ecclesiastical institutions were everywhere attacked, and ofien destroyed. And these institutions were centres of scholarship. Heretofore Ireland had been the special home of learning, and had attracted to itself large numbers of foreign students. But in those disastrous centuries its culture was reduced to the lowest point. In such circumstances it was not possible that the organization of the Church should be developed or strengthened. 'The Danish domination of the country must have tended to stereotype the old hierarchical system. It might, indeed, suffer from deterioration: it probably did. But it could not be assimilated to the system which then prevailed on the 
Continent. We should expect that the constitution of the Church in the eleventh century, whatever abuses may have crept into its administration, would in principle be identical with that of the pre-Danish period.

There can in fact be no doubt that it was. We have in our hands writings of Lanfranc, Anselm, St. Bernard and Giraldus Cambrensis which picture the state of the Irish Church at that time. They speak of it in terms which are by no means complimentary. But when they come to details we discover that the irregularities in its hierarchical arrangement which shocked them most went back to the days of St. Columba. Quotations cannot be given here. But the reader will probably find in the Life printed below, and the authorities referred to in the notes, sufficient proof that the constitution of the Irish Church in 1100 was in the main a following, though perhaps a corrupt following, of that of the sixth century. ${ }^{1}$

There was indeed one abuse in the Irish Church of the tenth and eleventh centuries of which few traces are found before the Danish invasion. IVe learn from St. Bernard that the abbots of Armagh were the representatives of a single family, and held office, as of right, by hereditary succession. ${ }^{2}$ There is reason to believe that this evil custom was not peculiar to Armagh. ${ }^{3}$ According to St. Bernard, it was the gravest departure from Catholic tradition of which the Irish Church was guilty, and the parent of many evils. We shall hear more of it in the sequel. For the moment it is sufficient to note that it existed.

1 See p. 46, note $\mathbf{I}$, and Additional Note B.

2 Life, \$ 19.

3 R. King, Memoir Introductory to the Early History of the Primacy of Armagh, 1854, P. 22. 


\section{The Beginnings of the Movement}

But before the eleventh century ended forces were at work in Ireland which prepared the way for the introduction of a new order. They were set free by the conversion of the Norsemen to Christianity, and by their final defeat at the battle of Clontarf. The date of the conversion cannot be fixed : it was probably a gradual process. And we do not know from what source the Danes derived their Christianity. The victory of Clontarf was won on Good Friday, Ior 4 .

Now a study of the Annals reveals the fact that in the seventh and eighth centuries there was a goodly, and on the whole an increasing, body of scholars in Ireland. Under the Norse domination, as we might expect, the number was greatly diminished. But already in the tenth century there was a notable increase: in the eleventh century the number was doubled. In the tenth century, moreover, and still more in the eleventh, scholars began to congregate at spécial centres, which became permanent homes of learning, the most prominent of these schools being at Armagh and Clonmacnoise. And during the same period we find frequent mention of an official, unknown before the arrival of the Norsemen, who is styled fer légind or professor. Between 925 and 1000 the obits of twenty-three professors are recorded; in the eleventh century of more than fifty. In the greater number of cases the fer legind is associated with one of those seats of learning which is known to have been most prolific of scholars.

Thus it appears that gradually, as the onslaughts of the Danes became less frequent, Irish men of learning tended more and more to become teachers rather than mere students, and to gravitate towards a few great centres of study. The climax of this movement towards 
organization and the eminence of special places was reached about the middle of the eleventh century (1030ro63), when mention is made of thirty-three persons who held the office of fer ligind, and when the principal schools seem to have been those of Clonmacnoise, Armagh, Kildare and Kells. ${ }^{1}$

The Reformation of the twelfth century, like that of the sixteenth, was prepared for by a revival of learning.

But further, the defeat of the Danes removed the barrier which had hindered communication between Ireland and the rest of Europe. Students once more came to Ireland from other lands to pursue their studies. The most remarkable of these was perhaps Sulien, the future bishop of St. Iavid's. Sulien the Wise was born shortly before the date of the battle of Clontarf in the district of Cardigan. In early youth he displayed much aptitude for learning, and in middle life, about ro $5 \mathrm{~s}$, "stirred by the example of the fathers," he paid a visit to the Irish schools in order to perfect his studies. He spent thirteen years in that country, and then established a famous school at Llanbadarn Fawr in Wales. In the library of Trinity College, Dublin, there is a precious relic of the work of this school. It is a beautiful manuscript of St. Jerome's Latin version of the I'salter according to the Hebrew, once the property of Bishop Bedell.2 The manuscript was written by a member of the school, a Welshman named Ithael. It is adorned with excellent illuminations by John, one of Sulien's sons, and was presented to Ricemarch, another son of Sulien. A valuable copy of the Hicronymian Martyrology prefixed to it gives sundry indications that it was transcribed

1 See Lawlor, I'salter and Martyrology of Ricemarch, vol. i., pp. ix-xii.

2 IIS. A. 4. 20. 
from an Irish exemplar. At the end of the volume are some verses composed by Ricemarch, and perhaps written there by his own hand. They display considerable Biblical and patristic learning. Another relic of the school is a copy of St. Augustine's De Trinitate in Corpus Christi College, Cambridge. ${ }^{1}$ It was written and illuminated by John, and contains excellent Latin verses from his pen. In the British Museum there is also a poem of Ricemarch describing the horrors of the Norman invasion of Wales. ${ }^{2}$ And finally we have a Life of St. David, by the same author. It relates many incidents culled from the lives of Irish saints who had in one way or another been brought into contact with David; all of them reminiscent of Sulien's studies in the Irish Schools. ${ }^{3}$

I have dwelt on these things because they illustrate in a striking way the revival of Irish learning in the eleventh century. But just at the time when Sulien, and doubtless many other foreigners, were coming to Ireland to study, Irish scholars were beginning to renew their ancient habit of travelling to other countries. By way of example I may mention two, both of whom were known by the same name, Marianus Scotus. One of these, a native of the north of Ireland, whose real name was Muiredach Mac Robartaich, founded the monastery of St. Peter at Ratisbon about 1070 ; and he was succeeded there by six abbots of north Irish birtl. $\mathrm{He}$ wrote a commentary on the Pauline Epistles, which is still preserved in the Imperial Library at Vienna. The other, Mael Brigte by name, left Ireland in 1056 , and after some wanderings established himself at Mainz in ro69. He compiled a chronicle, which is of consider-

\footnotetext{
1 MS. I 99.

2 Colton MS. Faustina, C. I, f. 66.

${ }^{3}$ Lawlor, of. cit., pp. xii.-xvii.
} 
able value. ${ }^{1}$ Hereafter I shall have to mention other Irish men of travel; and it will be seen that from some of them, who returned home, came the main impulse to the reform of the Irish Chureh.

The battle of Clontarf broke the power of the Danes in Ireland; but it did not secure their departure from the country. Those that remained were mainly settled in the four cities of Dublin, Wexford, Waterford and Limerick. In due time these four Danish colonies adopted the Christian Faith, and before long they became organized churches, each presided over by a bishop. In Dublin this took place a quarter of a century after the battle of Clontarf, the first bishop being Dunan, in whose episcopate the Danish king, Sitric, founded the Cathedral of the Holy Trinity about ro4o. Of the early ecclesiastical history of Wexford practically nothing is known; but the first bishop of Waterford was consecrated in $r \circ 96,2$ and the first bishop of Limerick eight or ten years later. ${ }^{3}$ These were the first churches in Ireland ruled by bishops who were not abbots; and it seems that each of the bishops had a defined diocese. The dioceses of Iublin, IVaterford, and perhaps Wexford, were very small, extending only a little way, if at all, beyond the walls of the Cathedral city. The diocese of Limerick, on the other hand, was extensive; rather larger than the present diocese of the same name. But whether large or small each of these dioceses presented to the eyes of the Irish a model of Church government similar to that in vogue on the Continent, and utterly different from that to which they were accustomed.

1 Lanigan, vol. iii. p. 446 ; vol. iv. pp. 2 -S ; Reeves, On Mturi. anus Scotus, extracted from the Natural History lieziew and Cuarterly' Journal of Science, July, I 860. B. NacCarthy, The Codex Palatino-Vaticanus, No. 330 , is92, 1p. 4 ff,

2 Below, p. I\$, nole 6.

3 See below, P. 47, note 3 . 
from an Irish exemplar. At the end of the volume are some verses composed by Ricemarch, and perhaps written there by his own hand. They display considerable Biblical and patristic learning. Another relic of the school is a copy of St. Augustine's De Trinitate in Corpus Christi College, Cambridge. ${ }^{1}$ It was written and illuminated by John, and contains excellent Latin verses from his pen. In the British Museum there is also a poem of Ricemarch describing the horrors of the Norman invasion of IVales. ${ }^{2}$ And finally we have a Life of St. David, by the same author. It relates many incidents culled from the lives of Irish saints who had in one way or another been brought into contact with l)avid; all of them reminiscent of Sulien's studies in the Irish Schools. ${ }^{3}$

I have dwelt on these things because they illustrate in a striking way the revival of Irish learning in the eleventh century. But just at the time when Sulien, and doubtless many other foreigners, were coming to Ireland to study, Irish scholars were beginning to renew their ancient habit of travelling to other countries. By way of example I may mention two, both of whom were known by the same name, Marianus Scotus. One of these, a native of the north of Ireland, whose real name was Muiredach Mac Robartaich, founded the monastery of St. Peter at Ratisbon about 1070 ; and he was succeeded there by six abbots of north Irish birth. He wrote a commentary on the Pauline Epistles, which is still preserved in the Imperial Library at Vienna. The other, Mael Brigte by name, left Ireland in 1056 , and after some wanderings established himself at Mainz in ro69. He compiled a chronicle, which is of consider-

1 MS. I 99.

2 Colton MS. Faustina, C. I, f. 66.

3 Lawlor, of. cit., pp. xii.-xvii. 
able value. ${ }^{1}$ Hereafter I shall have to mention other Irish men of travel; and it will be seen that from some of them, who returned home, came the main impulse to the reform of the Irish Church.

The battle of Clontarf broke the power of the Danes in Ireland; but it did not secure their departure from the country. Those that remained were mininly settled in the four cities of Dublin, Wexford, Waterford and Limerick. In due time these four Danish colonies adopted the Christian Faith, and before long they became organized churches, each presided over by a bishop. In Dublin this took place a quarter of a century after the battle of Clontarf, the first bishop being IJunan, in whose episcopate the Danish king, Sitric, founded the Cathedral of the Holy Trinity about ro4o. Of the early ecclesiastical history of Wexford practically nothing is known; but the first bishop of Waterford was consecrated in 1096,2 and the first bishop of Limerick eight or ten years later. ${ }^{3}$ These were the first churches in Ireland ruled by bishops who were not abbots; and it seems that each of the bishops had a defined diocese. The dioceses of Dublin, Waterford, and perhaps Wexford, were very small, extending only a little way, if at all, beyond the walls of the Cathedral city. The diocese of Limerick, on the other hand, was extensive; rather larger than the present diocese of the same name. But whether large or small each of these dioceses presented to the eyes of the Irish a model of Church government similar to that in vogue on the Continent, and utterly different from that to which they were accustomed.

1 Lanigan, vol. iii. p. 446 ; vol. iv. pp. $2-8$; Reeves, On Murianus Scotus, extracted from the Natural History keariew and Cuarterly Joumal of Science, July, I860. B. NacCarthy, The Codix l'alatino-Vaticanus, No. S3o, $1 S_{92}$, I'p. 4 ff,

2 Below, p. Is, note 6 .

${ }^{3}$ See below, p. 47, note 3 . 
'This might prove a potent factor in the Reformation, once a tendency developed among the Irish to bring their ecclesiastical machinery into conformity with that of the rest of the world. But it is manifest that by itself it would not induce them to re-model their hierarchy. It was not to be expected that they would cast aside the tradition of centuries, moved merely by a desire to imitate their late enemies. If, as is commonly held, the Danish dioceses, without exception, held themselves aloof from, or were hostile to, Irish Christianity, such a result could hardly have been attained, at any rate until the coming of the Anglo-Normans. These later invaders would doubtless have forced diocesan episcopacy on the Irish Church. But that it was established in Ireland before the country came, even in part, under English rule, is certain. So we must ask the question: What was the connecting link which bound the Church of the Danish colonists to that of Celtic Ireland? By way of answer $I$ point to the remarkable fact, often overlooked, that all the earliest bishops of the Danish dioceses were of Irish birth. Why Danish Christians should have elected Irishmen as their bishops I do not attempt to explain. But the evidence for the fact is clear.

The first two bishops of I)ublin, Dunan and Patrick (Gilla P'itraic), had unmistakably Irish names. So too had their immediate successors Donough O'Hanley and his nephew Samuel U'Hanley; and of these two the latter is stated by the English chronicler Eadmer' to have been "natione Hibernensis." The next bishop, Gregory - the first archbishop of Dublin-was likewise "natione Hibernensis" according to the continuator of Florence of Worcester. $^{2} \mathrm{He}$ was followed by St.

1 1. 73 .

2 Chronicle of John of Itorcestir, ed. J. K. H. Weaver, 19os, p. IU. 
Laurence O Toole, of whose nationality it is umnecessary to give proof.

Malchus, the earliest bishop of Waterford, was an Irishman; ${ }^{1}$ so also was Gilbert, the first bishop of Limerick. And when Gilbert resigned his see, after an episcopate of thirty-five years, he was succeeded by Patrick, whose name tells its own tale. ${ }^{2}$

Most of the Irish rulers of Danish dioceses whom 1 have mentioned were men of travel. Patrick of Dublin, to whose learning Lanfranc bears testimony, "was nourished in monastic institutions from his boyhood," 3 and certainly not in an Irish religious house. I)onough O'Hanley, before his consecration, was a monk of Canterbury; Samuel O'Hanley was a monk of St. Albans ; ${ }^{4}$ Malchus was called to Waterford from Walkelin's monastery at Winchester ${ }^{5}{ }^{5}$ Gilbert of Limerick had visited Normandy, ${ }^{6}$ and at a later date we find him assisting at the consecration of a bishop in Westminster Abbey. ${ }^{7}$ Such men had had training which

1 p. IS, note 6.

2 p. 47 , note 3, p. 73 , note 1 . I can name only three lishops of Danish sees who were apparently of I anish extraclion; and they all lived at a time when the Reformation was far advanced. They are Erolbh (Erulf?), bishop of Limerick, who died in I 5 I, and Tostius of Waterford and Turgesius of Limerick, who were in office in 1152 . A.F.M. 1151 , and Annals of Cloninagh quoled in Keating, iii. 317 .

${ }^{3}$ Ussher, $49 \mathrm{I}$.

1 Ware, hishops, cd. Ilarris, p. 309 ; Eadmar, p. 73.

5 Ussher, $5 \mathrm{IS}$; and below, Life, $\$ \mathrm{~S}$.

6 See P. 47, note 3 .

7 III 5. Eadmer, p. 236. Gougaud (p. 358) infers from this passage that Limerick was at that time a suffragan see of Canterbury. But this seems impossible in view of Gilberl's share in the proceedings of the Synod of Rathbreasal five years earlier. Eadmer is not a very good witness in such matters, and his language is hardly decisive for two reasons. (1) It is not clear that he includes Gillsert among the suffragans who co-operated in the consecration : "Hluic consecralioni interfuerunt el cooperatores extiterunt suffraganei ecclesine Cantuariensis, episcopi villelicet hi, Willelmus Wintoniensis, Robert us Lincoliensis, Rogerus Serberiensis, Johannes 
familiarized them with Roman methods of Church Government. 'They were well fitted to organize and rtile their dioceses. And if they desired to imbue the Celtic Church with the principles which they had learnt, and on which they acted, their nationality gave them a ground of appeal which no lane could have had. It is of course not to be assumed that all of them were so disposed. The Danish Christians of Dublin not only stood aside from the Celtic Church; for reasons which will appear later they were inimical to it, and it to them. Their bishops, with the possible exception of the first, made profession of canonical obedience to the English Primates. Not only so: they gloried in their subjection to Canterbury. "We have always been willing subjects of your predecessors," wrote the burgesses and clergy of Dublin to Ralph, archbishop of Canterbury, when

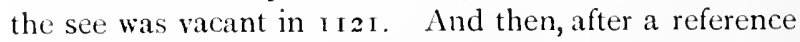
to the great jealousy of Cellach of Armagh against them, they proceed to declare, "We will not obey his command, but desire to be always under your rule. Therefore we beseech you to promote Gregory to the episcopate if you wish to retain any longer the parish which we have kept for you so long." I It was clearly impossible that this diocese could directly influence the Irish in the direction of reform. But no such obstacle barred the path of the first bishops of Limerick and Waterford. Gilbert owed no allegiance to Canterbury; Malchus was consecrated at Canterbury, but he soon escaped his profession of obedience to Anselm. ${ }^{2}$

Bathoniensis, Urbanus Glamorgatensis, Gislebertus Lumniensis de Hilernia." (2) The word "suffragan" is often usect as meaning merely an assistant bishop. Thus in the fifteenth cenlury several bishops of Dromore were "suffragans" of the archbishop of York; but Dromore was cerlainly not regarded as one of his suffragan sees.

1 Ussher, 532.

2 See p. xxxvi. 
Both became leaders of the romanizing movement in Ireland.

But the influence of the Danish dioceses on the Irish Church was not limited to the personal action of their bishops. Indirectly all of them, including I ublin, had a share in promoting the Reformation. Archbishop Lanfranc, as early as 1072 , claimed that his primacy included Ireland as well as England. ${ }^{1}$ The claim, curiously enough, was based on liede's History, in which there is not a single word which supports it. But the arrival two years later of Patrick, elect of Dublin, seeking consecration at his hands, gave him his opportunity to enforce it. When Patrick returned to take possession of his see he carried with him two letters from Lanfranc. One was addressed to (iothric, the Manx prince who for the moment was king of Dublin. Lanfranc, with tactful exaggeration, dubs him "glorious king of Ireland," and tells him that in consecrating Patrick he had followed the custom of his predecessors in the chair of St. Augustine. 'The other letter was more important. It was directed to Turlough O'Brien, grandson of Brian Boroimhe, who is also styled, inconsistently, and not altogether truly, "magnificent king of Ireland ": he was doubtless king of Ireland in hope, but in fact he never extended his sway beyond the southern half of the island. Turlouglis attention is called to the irregularities of the Irish Church. He is urged to call a council of bishops and religious men for the extirpation of those evil customs, and to be present at it in person. This letter evidently produced an impression, and not only on Turlough O'Brien. For a few years later Lanfranc wrote another letter, this time to a bishop named Donnell and others, who had

1 Ussher, 567; Riati Lanfranci Ofera, ed. J. A. Giles, Oxon., IS 44 , vol. i. p. 24 . 
sought his advice on a difficult question concerning the sacrament of baptism. ${ }^{1}$

Anselm followed in the footsteps of Lanfranc. Not long after his consccration (ro9.3) he wrote to Donnell, Donough O'Hanley and the rest of the bishops of Ireland, begging the aid of their prayers, and urging them to consult him in all cases of difficulty. Almost immediately afterwards came the election of Malchus, bishop of Waterford, in 1096 . Among those who signed the petition for his consecration were Bishop Donnell, Samuel O'Hanley, whom Anselm had consecrated for Dublin earlier in the same year, and O'Dunan, bishop of Meath (Idunan episcopus Midiae), whose name we shall do well to remember. But most notable of all were Murtough O'Brien, son of Turlough, then the strongest of Irish kings, soon to be ardri, and his brother Dermot O'Brien. $^{2}$ It is clear that Lanfranc had won the O'Briens to the Romanizing side; and Anselm was determined to hold them fast. Within the next few years there was a fairly regular correspondence between him and Murtough, of which some letters have been preserved. $^{3}$ The relation between the two men was evidently most friendly. And the archbishop fully exploited his opportunity. Again and again he reminded the king of his duty to repress abuses, the most important of which in his eyes were lax sexual morality, and the consecration of bishops by single bishops, without fixed sees or defined dioceses.

So Lanfranc and Anselm schooled the O'Briens in the principles of Rome. And from one point of view their efforts were completely successful. The O'Briens

1 See Ussher, 490-497; I':L. cl. 532, 535, 536. This Donnell was probal,ly Donnell O'Heney (Ua bEnna), a Niunster bishop who died in 1095 (A.U.).

2 Ussher, 515-519. The letter to Donnell is also in P.L. clix. 262.

${ }^{2}$ Ussher, $520-527 ;$ r.L. clix. 173, 178,243 . 
became staunch friends of the Reform movement in Ireland. But from another point of view they failed. We must remember that their aim was not only to purify the Irish Church, but to bring it into subjection to Canterbury. That they did not succeed in doing. The Reformation, which they taught the O'Briens to support, meant, in the end, a repudiation of the pretensions of the English primates.

I have mentioned among those who were concerned in the election of Malchus of Waterford, O'Dunan, bishop of Meath. He is unquestionably Míel Muire Ua Dunáin, whom the anmalists describe as "learned bishop of the Goidhil, and head of the clergy of Ireland, and steward of the almsdeeds of the world," and who died on Christmas Eve, i 17 , at the age of seventy-six. $\mathrm{He}$ is mentioned in a charter in the Book of Kells, the date of which is apparently about 1100 , as Senior of Leath Chuinn (i.e. the north of Ireland). ${ }^{1} \mathrm{He}$ was fifty-five when Malchus was elected, and had probably already attained the eminence throughout Ireland which is attested by the high-flown phrases of the Annals. That he was then bishop of Meath in the modern sense is impossible; the title at that period would mean no more than that he was a bishop who lived within the borders of the Kingdom of Meath. But the Annals of Tigernach tell us that he died at Clonard, from which it may perhaps be inferred that his see was at that place. His importance for us just now is that he is the only adherent of the Reform movement whom we have yet discovered in the north of Ireland.

1 Miscellany of Irish Archaological Socicty, vol. i. (IS4fi), p. $13^{6}$. 


\section{II.-The First Stage}

Before proceeding further in our investigation of the origin and course of the Reformation, it may be well to recall how far we have already advanced. We started from the fact that a Reformation of the Irish Church was actually accomplished in the twelfth century, and we proceeded to look for the causes which may have brought it about. We have found that the first of these was the revival of learning consequent on the cessation of the ravages of the Norsemen. We have noted also the restoration at the same period of communication between Ireland and the rest of Europethe coming of students to the Irish schools, and the wanderings of Irish scholars in other lands. We have seen that the establishment of the Danish dioceses gave to the Irish a model of diocesan episcopacy, and that among the Irish-born bishops of those dioceses there were men capable of leading a Reform movement. And we have learned that Lanfranc and Anselm, through their relation with the Danish dioceses, found means to induce the more conspicuous civil and religious leaders of the Celtic population to undertake the work of reconstituting the Church. Finally, we have been able to name some persons who might be expected to take a prominent place in the early stages of the Reformation. They are Gilbert of Limerick, Malchus of Waterford, O'Dunan of Meath, and the princes of the O'Brien family. The best proof that we have rightly conceived the origin of the movement will come before us when we study the share which these persons severally had in promoting it.

We must now trace, as far as it can be done, the first steps in the process by which, under the influences 
which I have indicated, the Church of Ireland passed from its older to its later hierarchical system.

The earliest attempt to give concrete form to the principles of the Reformers seems to have been made in the Kingdom of Meath, about the year r roo. But the primary evidence for the fact is of much later date. There are extant some constitutions of Simon Rochfort, bishop of Meath, put forth at a synod of his diocese held at the monastery of SS. Peter and Paul at Newtown, near Trim, in I 2 I 6 . The first of them recites an ordinance of the papal legate, Cardinal John laparo, at the Council of Kells in $15_{52}$, which is of great importance.

Paparo ordered that as the bishops of the weaker sees died off, arch-priests, or, as we call them, nural deans, should succeed to their place, and take charge of the clergy and people within their borders. ${ }^{1}$

The inference which this enactment suggests is that the weaker sees to which it refers were the centres of small dioceses, which Paparo desired to be converted into rural deaneries. In accordance with the ordinance of Paparo, Rochfort's synod enjoined that rural deans should be placed in the five sees of Trim, Kells, Slane, Skreen and Dunshaughlin, each of whom should supervise the churches in his own deanery. These, with Clonard, which had long been the see of Rochfort's diocese, are six of the twelve rural deaneries into which the present diocese of Meath is divided. ${ }^{2}$ I conclude that they, and probably the remaining six, coincided

1 Wilkins, Concilia, i. 547. In the form in which Rochfort quotes it the ordinance applies to the whole of Ireland. But we have no evidence of the transformation of dioceses into deaneries outside Meath; and it is quite prohable that a synod held in Neath would have in view, in such a decree, only the conditions which prevailed in that district.

"The deanery of Dunshaughlin is now named Ratoath. The deanery of Kells has been divided into Upper and Lower Kells. 
more or less closely with dioceses ruled by bishops in the first half of the twelfth century. ${ }^{\text {] }}$

Let us now call to our aid a much earlier witness. The annalists inform us that in the year 1 I I I there was an assembly at Usnagh in Meath. It decreed that "the parishes" of Meath" should be equally divided

1 The cogency of this argument is enhanced when we olserve that there is strong independent evidence for the existence in the twelfth century of one of the six dioceses - the diocese of Kells. (a) Up to the latter part of the sixteenth century $\left({ }_{5} \delta_{3}\right)$ there was an archdeacon of Kells, as well as an archdeacon of Meat $l_{1}$; the jurisdiction of an archdeacon (at any rate in Ireland) seems to have been always originally co-extensive with a diocese. The first known archdeacon of Kells was Adam I'etit who was in office in 1230 (K.T.A.279; C.IKA. i. IOI); but it is unlikely that he had nopredecessors. (b) Among the prelates who greeted Ilenry II. at Inblin in 1171 was Thadlaens, hishop of Kells (Benedict of P'eterborough (K. S.), i. 26). (c) In the time of Imocent III. (IIgS-1216) the question was raised in the papal euria whether the lishop of Kells was subject to the archlishop of Armagh or the archbishop of Tuam (Theiner, p. 2). (d) The bishop of Kells is mentioned in a document of the year I202 (Cal. of Docts. Ireland, i. I6S). (c) A contemporary note records the suppression of the bishopric: "When a Cistercian monk. . . had been elected and consecrated bishop of Kells by the common consent of the clergy and people, and had been confirmed by the Pope, the impudent bishop of Meath cast him ont with violence and clared to [add] lis lishopric to his own" (C.M.A. ii. 22). This statement implies that the dispossessed bishop ruled over a diocese. Moreover, when we remember that the see was certainly suppressed before Kochfort's Synod of 1216 , that Rochfort " as the first person who assumed the litle "bishop of Meath" in the modern sense, and that a bishop of Kells died in 12I I (A.L.C.), we need not hesitate to conclude that the "impudent bishop" was Rochfort himself, and that the suppression was accomplished about 1213 .

${ }^{2}$ I.e. dioceses. This synod is mentioned in A.T., A.I. and the Annals of Boyle. Particulars of its Acts and of the persons present at it are given in C.S. and D.A.I. C.S. has "parish" in the singular. But this does not seem to yield good sense; for the whole extent of the kinglom of Meath could scarcely have been called a "parish" in the twelfth century. I therefore read "parishes," The singular may have been substituted for the plural at a later time, when the kingtom (or the greater part of it) included unly the dioceses of Meall and Clommacnoise, and their earlier history was forgotten. CP. the unhistorical statement of St. Bernard about Down and Connor in Life, $\$ 3 \mathrm{I}$. D.A.I. have an anomalons form (faircheadh), which may have come from either 
between the bishops of Clonmacnoise and Clonard. We may infer that Clonmacnoise and Clonard, two of the present rural deaneries, were then dioceses. It is not likely that the dioceses of Meath would have been formed into two groups, each to constitute the diocese of a bishop who had already no diocese of his own. But however that may be, we have here proof that before i II I Neath had been parted into a number of small dioceses ruled by bishops.

If the question be asked, By whose authority or influence this division of Meath into dioceses was made? I can suggest no one more likely than Máel Muire Ua Duníin, the "bishop of Meath" to whom reference has already been made. ${ }^{3}$ He was a Meath man, and probably bishop of Clonard: he was an ecclesiastic of great repute, especially in the north; and he was a devoted adherent of the Reform movement. His action, if indeed it was his, was premature and ill-advised. As we shall see, his work had to be slowly undone. But it is remarkable, as the first attempt known to us to establish diocesan episcopacy among the Irish. I shall have more to say about it hereafter; but now I must follow the main stream of events.

Gilbert," the first bishop of Limerick, as has already been noted, was an Irishman. Indeed, we may venture to describe him as one of the most remarkable Irishmen of his time, in spite of the fact that the Amnals pass him by in almost complete silence. He was at any rate a staunch supporter, or, as we should rather say, the leader of the Reformation movement in its carliest course. In a letter written in I I07 Anselm exhorted him, in virtue of their mutual friendship, to make good

the singular (fairihe) or the plural (faircheadha) in the exemplar, but more probably from the latter.

$$
1 \text { p. xxiv. f. } 2 \text { See } 1 \text { ' } 47 \text {, note } 3 .
$$


use of his episcopal office by correcting that which was amiss, and planting and sowing good customs, calling to aid him in the work his king (Murtough O'Brien), the other Irish bishops, and all whom he could persuade. ${ }^{1}$ That, assuredly, Gilbert was forward to do.

No sooner had he taken possession of his see than he began to organize a diocese. Its boundaries seem to have been fixed with care. It was exactly co-extensive with the modern diocese of Limerick, except on the north, where it stretched across the Shannon and included part of the present diocese of Killaloe. ${ }^{2}$ Moreover he made the Church of St. Mary his Cathedral Church; indeed it is not unlikely that he built it to serve that purpose.

A few years later he was appointed Legate of the Holy See. It is manifest that his new office gave him a unicpue opportunity of moulding the fortunes of the Irish Church. In Ireland Gilbert was now virtually the chief prelate and head of the Church. He was the representative and embodiment of the authority of the Holy See. 'The whole Romanizing party would naturally circle round him as their leader, and many waverers would be attracted to the new movement in the Irish Church, by the claim which he could make to speak in the name of the head of the Church Catholic.

It was after he became legate, and no doubt in virtue of his legatine commission, that he issued a treatise which may be regarded as the programme of the Reformation. It is entitled De Statu Ecclesiae. Of this a fragment, including its earlier chapters, is still in our hands. ${ }^{3}$

1 Ussher, 513.

2 A small portion of the present diocese of Limcrick lies north of the Shannon.

3 Ussher, 501 ff. ; I'.L. clix. 995. 
Before giving a slight summary of its contents I must mention that it is addressed "to the bishops and presbyters of the whole of Ireland," and that Gilbert declares that he wrote it at the urgent request of many" of them. In this statement there may lurk an element of exaggeration. But behind it there lies at least so much truth as this. A considerable body of the clergy had approached the newly made legate, and requested his instruction regarding the proper constitution of the Church-for such is the subject of his tract; and that implies that the Romanizing movement was no longer in its infancy. There were many bishops and presbyters who had become dissatisfied with the old Irish method of Church government. They desired to bring it into conformity with that of the Roman Church. But they were in some uncertainty as to the nature of the changes that should be made, and so they asked Gilbert to give them authoritative counsel.

In reply to their petition, with the aid of an elaborate diagram, he sketched as follows the organization of a properly ordered Church.

'The bishops, he tells us, and others of higher rank in the ministry belong to the general Church, as distinct from particular churches. The priest is the highest officer in a particular church. It is the primary duty of every priest to serve and obey his bishop with all humility. For by the bishops particular churches are ruled. 'To each bishop are subject all the churches within his jurisdiction. And this applies as well to monastic establishments as to parishes. The head of each parish is a priest, the head of each monastery is an abbot, who is himself a priest. The bishop has a pontifical church, in which is his see (sedes), and of which he is the head. From it he governs the inferior churches. A bishop can perform all the offices of a 
priest, but he has seven functions peculiar to himself: to confirm, to bless, to absolve, to hold synods, to dedicate churches and altars, to consecrate the ornaments of ehurches, to ordain abbots and abbesses and the secular clergy. Gilbert's diagram represented the bishop as ruling two churches; but he explains that this is to be interpreted figuratively. A bishop may have as many as a thousand churches within his jurisdiction: he must have at least ten.

A bishop is himself subject to authority. His immediate superior is the archbishop. An archbishop has a sphere of immediate jurisdiction, like any other bishop, but he also rules a number of subject bishops. Of these there must be at least three; but an archbishop is not permitted to have more than twenty subject bishopsan inportant point, as we shall see. Above the archbishop is the primate. It is the special privilege of the primate to ordain and crown the king. He too has his sphere of immediate jurisdiction, and he must have at least one subject archbishop, but not more than six.

Primates and archbishops must be consecrated at kome by the Pope, or at least must receive the pall ' from him. Without the pall they are not raised above their fellow-bishops.

Finally, the primates are subject to the Pope, and the Pope to Christ.

The higher members of the hierarchy have their analogues in the civil order. The Pope corresponds to the emperor, the primate to the king, an archbishop to a duke, a bishop to an earl, a priest to a knight. But all these are merely grades of the order of priests. There are but seven orders of the ministry-priests, deacons, sub-deacons, acolytes, exorcists, readers and door-keepers.

1 Sec p. 65, note 1 . 
Of the laity Gilbert says little. 'They are of two classes: husbandmen and soldiers. Their duties are to attend church, to pay first-fruits, tithes and oblations, to avoid evil and do good, and to obey their pastors.

There is nothing original in all this; and some parts of it must have been very puzzling to stay-at-home 1rishmen. For example, what were they to make of Gilbert's comparison of primates, archbishops, bishops and priests to kings, dukes, earis and knights? They knew as little of dukes and earls in the civil order as they did of prinates and archbishops in the ecclesiastical ; and they had far more kings than suited (iilbert's scheme. But the tract is important, both as a summary of the teaching which Gilbert had no doubt been inculcating far and wide for years, and as a permanent record, for future use, of the aims of the Reformers.

However unintelligible the treatise may have been in parts, it brought out with startling clearness one or two essential points. First the Church must be ruled by bishops. Even the monasteries are subject to them. How amazing such a statement must have sounded to men who had inherited the tradition, many centuries old, that the abbots of monasteries were the true ecclesiastical rulers, bishops their subordinate officials.

Moreover, hishoprics and dioceses could not be set up at random. The number of bishops and by consequence the size of dioceses must be carefully considered. The puny bishoprics of Meath, for example, could form no part of a scheme such as Gilbert adumbrated.

It was manifest that if his guidance were to be followed. no mere modification of existing arrangements would suffice. The old hierarchy must be torn up by the roots, and a new hierarchy planted in its place.

We shall meet Gilbert again in the course of our story. But we may now turn aside from him to make the C 
acquaintance of a new actor in the drama of the Reformation. Like O'Dunan he was a Northern.

Cellach was born in Ioso. He was an Armagh man, sprung from the family which for centuries past had provided abbots for the monastery of that city, the grandson of a former abbot. He first appears on the scene in I I05, when on the death of Abbot Donnell he became coarb of Patrick and abbot of Armagh. He was elected, we may assume, in the customary way. He was then under twenty-six years of age, and was apparently still a layman. But his subsequent action shows that he was already a convinced disciple of the new movement. Doubtless he had fallen under the spell of Gilbert of Limerick. Six weeks after his election he abandoned the tradition of a century and a half, and received holy orders. But in other respects he trod in the footsteps of his predecessors. In the following year he went on a circuit of the Cenél Eoghain, and "took away his full demand: namely, a cow for every six, or an in-calf heifer for every three, or a half ounce of silver for every four, besides many donations also." Next he proceeded to Munster, with similar results. But his circuit of Munster is important for other reasons. There he had opportunities of intercourse with his Munster friends, Gilbert of Limerick and Malchus of Waterford. And with that circuit we may connect two incidents of of the lighest significance. In 1106 , apparently in the latter part of the year, Caincomrac Ua Baigill, bishop of Armagh, died. The news of his death probably reached Cellach while he was in the south. Certainly in Munster Cellach was consecrated bishop. It is impossible not to connect the latter event with the former. He was consecrated to fill the vacancy created by the death of O'Boyle. 'Thus he was now bishop of Armagh as well as coarb of Patrick. In his own person he united the 
two lines of coarbial and episcopal succession, which had parted asunder in 957 , when the first of a series of lay coarbs had been elected, and the first of the six contemporary bishops had been consecrated. ${ }^{1}$ This was a great gain for the Reformers. The old anomaly of a ruler of the Church who was not a bishop had, so far as Armagh was concerned, disappeared for the time. And Armagh was the principal ecclesiastical centre in Ireland. Cellach might now call himself archbishop of Armagh, though he had not fulfilled the condition laid down by Gilbert, that an archbishop must receive the pall at the hands of the Pope. The title was actually accorded to him by so rigid a papalist as St. Bernard. ${ }^{2}$

But there was more to come. In the year IIor there had been held at Cashel a great assembly of the clergy and people of Ireland. Bishop O'Dunan, whom we already know, was at their head. 'To it came also Murtough O'Brien, who earlier in the year, after an expedition in force through Connaught and Ulster, had entered Tara as ardri of Ireland. ${ }^{3}$ In the presence of the assembly he surrendered Cashel, the royal city of the kings of Munster, to the Church, as an offering to God and St. Patrick. When we consider the persons who were concerned in this transaction we find good ground for the suspicion that the gift was intended in some way to benefit the movement for reform. Now St. Bernard informs us that Cellach created a second archiepiscopal see in Ireland in subordination to Armagh. ${ }^{\mathbf{5}}$ After his manner he does not tell us where it was situated.

1 See Additional Note B, pp. 164, I66. The events of Cellach'; life are gathered from $A . U$.

2 Life, \$ 19.

${ }^{3}$ See MacCarthy's Note in $A$. U. I Ior.

4.F.M., Keating, iii. 297. Keating scems to confuse the erents of IIOI with those of I IO6.

5 Life, \$ 33 . 
It is certain, however, that it was at Cashel, which was the seat of an archbishop in I I Io. It was probably surrendered for this very purpose by O'Brien. And if it be asked when Cellach erected it into an archbishopric the answer is scarcely doubtful. Only once, so far as we know, did Cellach enter Munster before I I 10 . It was on the occasion of his circuit. In the year of the circuit, therefore, I 106 , the archbishopric of Cashel was founded. In that same year, or shortly afterwards, Malchus of Waterford was translated to the new see, and became its first archbishop. There is no evidence that a new bishop was consecrated for Waterford in succession to Malchus: this indeed is unlikely. But it should be noted that by his acceptance of an archbishopric subject to Armagh, Malchus was released from the profession of obedience which he had made to Anselm ten years earlier. He was now a bishop of the Church of Ireland, with undivided allegiance.

The reason for the creation of a second archbishopric is not difficult to guess. By this time the plans of the Reformers must have been in some degree matured: before long, as we shall see, they were set forth in minute detail. Already Cellach was archbishop of Arniagh. His suffragan sees, indeed, apart from those formed by O'Dunan, if their bishops acknowledged themselves as his suffragans, were in nubibus. But suffragan sees he must have, according to the theory of Gilbert, each with a diocese attached to it. 'They nust be at least three in number, but not more than tzerenty. Now it was a foregone conclusion that if the Reformers had their way there would be more than twenty dioceses in Ireland. Hence, by Gilbert's rule, there must be a second archbishop. Moreover, by making the archbishopric of Cashel subject to Armagh,

1 See p. IS, note 6 . 
Cellach secured for himself and his successors a title yet more imposing than that of archbishop. He was now Primate of Ireland ; for it sufficed, if Gilbert spoke truly, that a primate should have one subject archbishop. As coarb of Patrick Cellach's authority ranged over the whole country; as primate his sway would be no less extensive. He actually claimed the title, if not then, at least a few years later. ${ }^{1}$

We may now for a while leave Gilbert and Cellach and Malchus and O'Dunan. With Gilbert as legate, and Cellach and Malchus as archbishops; with dioceses already formed at Limerick and Waterford and in Meath, probably also at Armagh and Cashel and IVexford; with the great extension of the movement, and its spread from Munster to Meath and Ulster, all was ready for the meeting of the Synod whose ordinances should give definite shape to the policy to be pursued in the future.

\section{III. - The Synod of Rathbreasail}

Geoffrey Keating quotes from the lost Annals of Clonenag $h$ an account of a national Synod or Council held at Rathbreasail in the year Ir I0. ${ }^{2}$ 'The existing Annals record that a national Council met at Fiadh meic Oengusa in II II. With the exception of the Annals of Inisfallen, none of them mention Rathbreasail ; but the Inisfallen annalist tells us that it is another name for Fiadh meic Oengusa. ${ }^{3}$ I shall assume therefore that there were not two national Synods in successive years,

3 See next page.

2 Keating, iii. $299 \mathrm{ft}$. The date is there misprinted 1100.

3 I formerly disputed this identification, on the ground that the archbishop of Cashel who was present at Fialh meic Oengusa was O'Dunan (G. T. Stokes, Ireland and the Celtic Church, ed. 6, I907, p. 372). I ain now convinced that he was not archbishop of Cashel. I was not then aware that all MSS. of Keating date the Synod of Rathbreasail in I I ro. 
but one; and, following the Annals of Clonenash, I shall call it the Synod of Rathbreasail, and date it in 1 I 10.

The Synod of Rathbreasail marks the beginning of the second stage of the Reformation movement. It was convened by the papal legate; its purpose was the Romanizing of the Irish Church, and, in particular, the establishment in it of diocesan episcopacy. Fortunately Keating's excerpts from its Acts give us ample information concerning the canons which dealt with this matter.

The annalists, as I have said, describe the council as a national assembly. But we can hardly claim so much for it. It is much more probable that it was in reality a meeting of the Reforming party. 'The first signature appended to its canons was that of Gilbert, who presided as legate of the Holy See. He was followed by Cellach, "coarb of Patrick and Prinate of Ireland," and Malchus, "archbishop of Cashel," whom we have known as bishop of Waterford. 'The signatures of many bishops followed, but they have not been preserved. We know, lowever, that Bishop O'Dunan was present, as was also Murtough O'Brien, king of Ireland. 'These were all leaders of the Reforming party; and it is evident that they guided the deliberations of the Council. Moreover there were no representatives of the provinces of Connaught and Leinster, in which as yet, it appears, the Reform movement had not established itself. That is made clear by notes apjended to canons which specially concerned those provinces. One of them begins thus: "If the Connaught clergy agree to this . . . we desire it, and if they do not"-in that case they may do as they please, with certain limitations. The clergy of Leinster are accorded a similar liberty. It is obvious that if aniong the members of the Council there had been men who could speak with authority 
for the provinces mentioned such notes need not, and therefore could not, have been written. The Council represented Munster, Ulster and Meath. It was national, not because it could speak for all Ireland, but because it made laws for all Ireland.

I must now give an account of those laws, so far as they relate to the organization of the Church. I follow the Annals of Clonenagh, as reported by Keating: but in two or three places I have been obliged to amend his text. ${ }^{1}$

The fathers began by appealing to English precedent. "Just as twelve bishops were fixed under Canterbury in the south of England, and twelve bishops in the north under the city of York," so it was ordained that there should be twelve bishops in the south of Ireland, and twelve in the north. The constitution of the Irish Church was henceforth, it would seem, to be a copy of that of the English Church. But, as it happens, neither in I I IO nor in any other year of its history, had the Church of England twelve sees under Canterbury and twelve under York. How then can we explain the statement of the Synod? The answer is simple. Bede ${ }^{2}$ preserves a letter of Pope Gregory the Great, written in 6or, in which St. Augustine of Canterbury was directed to consecrate twelve bishops as his own suffragans. He was also ordered to consecrate a bishop for York, who, if his mission proved successful, was likewise to consecrate twelve suffragans, and to be promoted to the dignity of a metropolitan. It is clear that the Synod found its precedent in this letter, not observing that

1 On p. 298 read no (or) for is (and) before Dun da Leathghlas; and on p. 306 chathar for chuigear ar fhichid (i. e. twenty-four for twonty-five). On p. 306 a portion of the note on the Leinster diocese has evidently dropped out, which should be restored to bring it into conformity with the corresponding passage on p. 302 .

\% H.E. i. 29. 
Pope Gregory's ordinance was never carried into effect. But they made another mistake. For Gregory intended that there should be twelve bishops in the north of England, and twetve in the south, exclusive of the archbishops, twenty-six in all; while it is evident that the Council of Rathbreasail intended that there should be twelve bishops in the north of Ireland, and twelve in the south, including the archbishops, twenty-four in all. Some one whose lead the Synod followed-probably the papal legate-had read his Bede with little care. But that is not surprising. Lanfranc had misread Bede, when on his authority he claimed to be l'rimate of Ireland; why should not Gilbert have gone astray in like fashion? 'The point to be noticed and emphasized is that the first act of the Synod was to fix the number of the Irish sees, on the curious principle that what the wisdom of Pope Gregory held to be good for England would suit Ireland also.

Apparently the next step in the procedure was to determine the distribution of the dioceses among the provinces, and to fix the see of each prospective diocese. Ireland was divided into two portions by a line running, approximately, from Dublin to Galway. The part to the north of that line was known as Leath Chuinn, the part to the south as Leath Mogha. In Leath Chuinn were the provinces of Ulster and Connaught and the kingdom of Meath; in Leath Mogha were the provinces of Munster and Leinster. The Synod decreed that there should be five sees in Ulster, five in Connaught, and two in Meath, making twelve bishoprics for Leath Chuinn; there were to be seven in Munster and five in Leinster-twelve bishoprics for Leath Mogha. The names of all these sees were given in the Acts of the synod.

Finally the Synod defined the boundaries of the 
dioceses to which the sees severally belonged. It is not my purpose to give a minute description of these boundaries. That would involve an excursus on Irish topography, which would be, to say the least, out of place. It will suffice to indicate roughly those of the five dioceses of Ulster. To the west was what was called the "parish" ( fairche) ${ }^{1}$ of Derry or Raphoe. It was nearly identical with our diocese of Raphoe. The only important difference is that it included Inishowen, the district between Lough Swilly and Lough Foyle, which now belongs to the diocese of Derry. Next to the parish of Derry or Raphoe the Synod placed the parish of Ardstraw. ${ }^{2}$ Ardstraw never became the see, and the diocese was subsequently known as "of Derry." It extended eastward to the Carntougher Mountains, and coincides pretty closely with the present diocese. It subsequently gained Inishowen from its western neighbour, and the strip between the Carntougher Mountains and the Bann from its eastern neighbour. But otherwise it remains much as the Synod of Rathbreasail determined. Next to it was to be the parish of Connor or Down. When the portion of it to the west of the Bann was transferred to Derry, it coincided almost exactly with the modem Down, Connor and Dromore. On the other hand the parish of Armagh seems originally to have included the modern county of Monaghan: it has shrunk to little more than half its size. The parish of Clogher, at first very small, has extended east and west, and is three times as large as it was intended to be. On the whole the work of the Synod has stood well the test of many centuries of history.

It is indeed wonderful that it should have done so.

1 I.e. diocese.

2 The parish (using the word in its modern sense) in which is Newtown Stewart, co. Derry. 
For the method of the Synod--fixing the number of the dioceses before their boundaries were discussed-was unstatesmanlike. Always, and necessarily, ecclesiastical divisions have coincided with civil divisions. We may find the germ of the rule in the Acts of the Apostles. ${ }^{I}$ If this was inevitable in other lands it was even more inevitable in Ireland in pre-Norman days. 'The Irish people was a collection of clans, having, it is true, certain common institutions, but bound together by no sort of national constitution, and often at war with each other.' If ecclesiastical divisions were to be permanent in Ireland, they must take account of the tribal divisions of the country. The primary ecclesiastical unit must be the territory of a tribe, just as it was the primary civil unit. $^{2}$ But to base the limits of dioceses, consistently and in every case, on tribal boundaries was impossible when the number of dioceses was arbitrarily fixed beforehand. It could not be that exactly the same number of dioceses would suit Ulster as suited Leinster and Connaught. In one province the tribes would be more or less numerous, and more or less mutually antagonistic, than in another. By reason of its method, therefore, the Synod was doomed to fall short of complete success in its work.

We have instances in Ulster of the soundness of the principle that I have stated. Take the diocese of Raphoe. It was designed to include Inishowen. But from a tribal point of view Inishowen (Inis Eoghain) belonged to the next diocese, which included the tribeland of Tír Eoghain. Its inhabitants were of the same

1 Ramsay, Paul the Traveller (1907), p. 173.

2 Some changes of phraseology might have been made here and elsewhere if I'rofessor MacNeill's Phases of Irish History (1919) harl come into my hands before this volume went to press. But they would not have affected the argument. 
stock as the Cenél Eoghain, and were known as the Cenél Eoghain of the Island. So the natural result followed. Inishowen broke off from the diocese of Raphoe and became part of the diocese of Derry. When this happened the diocese of Raphoe was stabilized. It consisted of the land of a single tribe, the Cenćl Conaill ; and so henceforth its limits were never altered.

We can easily understand, therefore, that the disregard of tribal boundaries, forced on it in many cases by its method, was an element of weakness in the Rathbreasail scheme. And yet it was natural that special stress should be laid on the arbitrary limitation of sees which was its main cause. Ireland was overrun with bishops. It is said that over fifty of them attended the Synod of Rathbreasail; and they represented only part of the country. But Gilbert had laid down the rule that an archbishop could not have more than twenty suffragans. On this principle, if all the existing bishops had been provided with dioceses, or all the larger tribes had been given bishops, Ireland would have had not two, but six or seven archbishops: and this would have been a travesty of Catholic Church order, as it was then understood. It was essential that the number should be ruthlessly cut down.

But the legislators of Rathbreasail did not entirely ignore tribal boundaries. On the contrary, so far as the numerical basis of their scheme permitted, they took them into account. And here we find that the Synod was confronted with another difficulty. The territories of tribes were fluctuating quantities. Hence, even if a diocese was the district of a single tribe, with very definite boundaries, no one could be sure that in the course of years its limits would not change. Again I take an example from Ulster. The Synod selected the Carntougher Mountains as the boundary between the 
dioceses of Derry and Connor. And wisely. For between those mountains and the Bann there dwelt it sept-the Fir $\mathrm{Li}$-whose affinities were altogether with the people to the east of the river. But only a few years after the Synod that territory was overrun by the O'Kanes of the Roe Valley, and the Fir Li retreated across the Bann, never to return. The result followed which might have been expected. Their territory was transferred from Connor to Derry, and the Bann to this day is the boundary of the two dioceses. ${ }^{1}$

It may be well, before I pass to another subject, to call attention to some special features of the Rathbreasail canons.

First, let us note the prominence which is given to Limerick, the diocese of Gilbert, the president of the Synod. Usually a diocese is somewhat vaguely defined by four places on its borders. But here no less than thirteen are named. So full are the indications that a fairly exact map of the diocese could be drawn. Further, in this diocese alone mention is made of a Cathedral Church: "The Church of Mary in Limerick is its principal church." 2 Note the present tense: "The Church of Mary is"-not shall be-"its principal church." We remember that Gilbert insisted in the De Statu Ecclesiae that a diocese should have a "pontifical church." Again, the boundaries of this one diocese are protected by a clause which has no parallel elsewhere: "Whosoever shall go against these boundaries goes against the Lord, and against Peter the Apostle, and St. Patrick and his coarb and the Christian Church." Who but the legate of the Pope would have thus invoked St. Peter?

Surely this portion of the ordinances of the Synod

1 See Irish Church Cuarterly, vol. x. p. 234.

- Agus is é teampull Muire i Luimneach a príomheaglais. 
must have been penned by Gilbert himself. And the whole passage- - by the minuteness of its description of the diocese, by the strength of the terms in which it is expressed, by the reference to the Cathedral Church as already existing--suggests that the diocese was formed and organized before the Synod met, as I have already assumed. We may even suspect that an attempt had been made to invade it, which Gilbert stoutly resisted, relying on his legatine authority.

In the list of dioceses there is an omission which demands cxplanation. No mention whatever is made of Dublin, the oldest diocese in Ireland. Not only so; the northern limit of the diocese of Glendalough is marked by Lambay Island and Greenogue, which lies due west of it in the County Meath. Thus the diocese of Glendalough, as contemplated by the Synod-and, it may be added, as it was in fact forty years later ${ }^{1}$-included the whole of the actually existing diocese of Dublin. The Danish Christians of Dublin and their Irish bishop are treated as interlopers; they are absolutely ignored. It may be said that this was due to the mutual hostility which divided the diocese of Dublin from the native Church, and to the fact that the bishops of Iublin had always been subject to Canterbury. liut it is not enough to say this; for the estrangement of Dublin from the Irish is the very thing that has to be accounted for.

It had its root in the growing prosperity of the Danish city. The Irish had no towns. Town life was introduced among them by the Norsemen. And of their towns Dublin was always the chief. By this time it had become so important that it had good right to be called

1 When Cardinal Paparo came to Ireland in I 15 I he found " a see constituted at Dublin in the diocese of Glendalough."-- Crite Mihi (ed. Gilbert), p. I I. 
the metropolis of the country. And its citizens were thoroughly aware of this. As early as 1074 the burgesses of Dublin and their bishop, Patrick, claimed for it that title. ${ }^{1}$ Now in all reason a metropolis should have a metropolitan as its bishop; and no doubt the bishops of Dublin thought themselves de facto, if not de jure, superior to the other bishops of Ireland. In fact we find one of them playing the archbishop. We have two interesting letters of Anselm, written apparently about I 100 . One of them is addressed to Malchus, bishop of Waterford, directing him to rebuke Samuel O'Hanley, bishop of Dublin, for various irregularities, in particular for having his cross carried before him like an archbishop : the other is addressed to Samuel himself, and complains of the same actions. ${ }^{2}$ These proceedings are not likely to have been brought to an end by Anselm's letters; and we may assume that they were continued as long as Samuel held the see of Dublin. It was but natural that Cellach should strongly resent them, for they were disrespectful both to himself and to the archbishop of Cashel. IVe are not surprised, therefore, to find that on the death of Samuel in I I 2 , eleven years after Rathbreasail, Cellach tried to get possession of the Church of Dublin, ${ }^{3}$ most probably with the intention of bringing it under the jurisdiction of the bishop of Glendalough. Nor are we surprised that the men of 1 Jublin at once replied by electing another bishop and bidding Ralph of Canterbury to consecrate him if he desired to retain the suffragan see which they had so long preserved for him. ${ }^{4}$ We shall see hereafter how the bishops of Dublin were at length induced to

1 Ussher, 488 (P.L. cl. 534), 564.

2 litid. 528, 530 ; P.L. clix. 109, 2 I6.

3 See p. 2o, note 3 .

4 See p. xxii. 
look with favour on the Irish Church. Meanwhile we learn that they were not very obedient suffragans of Canterbury; and we cease to wonder that they were ignored in the Rathbreasail decrees.

Another feature of the canons of the Synod is worth noting. In several instances the see of a diocese was not absolutely fixed. Two places were named, and it was apparently left to the bishop of the future to select that one of the two which he preferred to be his city. Thus we have a diocese of Derry or Raphoe, a diocese of Connor or Down, another of Wexford or Ferns, and so forth. The meaning of this is best seen by taking a single example. To one of the dioceses of Munster was assigned the area now occupied by the two dioceses of Waterford and Lismore. It consisted of the original I anish diocese of Waterford, together with a much more extensive non-1)anish area. Alternative sees were named; it was described as the parish of Lismore or Waterford. Now Lismore was the most sacred spot in the enlarged diocese. It was the site of a monastery founded by St. Nochuta. It was an icleal place for a bishop's see. But it was doubtless ruled at the moment by an abbot, the coarb of Mochuta. Unless he was prevailed on to accept episcopal orders, or was deprived of his authority, a diocesan bishop could not be established there. On the other hand, Waterford had no sacred traditions; but it was already the see of a diocese. In default of Lismore it would be a convenient place for the see. Between Lismore and Waterford the circumstances of the future must decide. Ultimately, it appears, Malchus retired from the archbishopric of Cashel, and became bishop of his older diocese, now so much greater than it had been. He placed his stool, however, not at Waterford but at Lismore. ${ }^{1}$ A similar, 
but not always identical course Lwas followed in other such cases.

What the Synod of Rathbreasail actually accomplished was this. It gave to Ireland a paper constitution of the approved Roman and Catholic type. But by doing this it had not achieved the purpose of its existence. In the years that followed, its enactments had to be carried into effect. And here was the real crux. Before the Church came to be ruled by diocesan bishops, the existing rulers - the coarbs of church founders-must be dispossessed of their authority; the numerous bishops of the old Irish type must be got rid of ; the jurisdiction of the new bishops must be fixed by common consent, or enforced without it; and revenues must be provided for them. A mere synodal decree could not accomplish all this. The diocesan system could become a fact throughout the whole Church, and the last vestiges of the ancient constitution be made to disappcar, only after determined effort, and probably bitter contention. And when all was done it would certainly be found that the scheme of dioceses arranged at Rathbreasail had heen largely departed from.

I can best illustrate the nature of the difficulties which had to be encountered, and the length of time which might be required to overcome them, by giving a short outline of the history of the forming of the dioceses of the kingdom of Meath.

In Meath, as we have seen, there were dioceses ruled by bishops before Rathbreasail. But these dioceses were of small size. It may be doubted whether most of them fulfilled the condition laid down by Gilbert, that a bishop should have not less than ten churches within his jurisdiction. They had therefore to be grouped under a smaller number of prelates. What had to be accomplished in this case was not so much the clipping of the 
wings of the abbots, as the extirpation of the more recently appointed diocesan bishops. The Synod determined that the kingdom should be divided into two dioceses, one in the west, the other in the east. 'The western see was to be at Clonard, at the moment, as it seems, the see of O'Inunan, and famed as the site of the great monastery of St. Finnian, founded in the sixth century; the eastern see was to be at Duleek, near Drogheda. Now a few months after the Synod of Rathbreasail there was held at Usnagh a local synod of the men of Meath, at which the king and many notable persons were present. ${ }^{1}$ This synod ordained that the parishes of Meath should be equally divided between the bishops of Clonmacnoise and Clonard. It will be observed that the principle of the Rathbreasail decree was accepted, that there should be two, and only two, dioceses in Meath. Put the change made in the sees is signifieant. The Synod of Rathbreasail intended that Clonard should be the see of the western diocese, which would include Clonmacnoise. The Synod of Usnagh demanded that Clonmacnoise, founded by one of the most noted of Irish saints, St. Ciaran, should be one of the surviving sees, and that Clonard should be the see, not of the western, but of the eastern half of the kingdom. Thus the Synod of Rathbreasail was at once met with strenuous and, as it proved, successful opposition in Meath.

And here I may mention another fact. A few years after the Synod we have proof of the existence of a diocese in the north of the kingdom, which has not hitherto been mentioned, and which is not named in the Rathbreasail canons. We know it as the diocese of Kilmore. ${ }^{2}$ It may have been one of O'Dunan's

1 Sec alove, p. xxviii.

2 There was a bishop of breifne (i. c. Kilmore) in 136 (A.T.). 
dioceses, or it may have been founded later. One thing is certain. The diocese formed the territory of a strong tribe. Consequently it had in it the element of stability. It was never suppressed : it exists to this day. So far as it was concerned the canons of Rathbreasail were a dead letter from the beginning.

But let us return to Clonard. It was the business of its successive bishops, in accordance with the decrees of Usnagh, to annex the small neighbouring bishoprics of east Meath. They had considerable success. IVe possess a list of churches granted by Eugenius, the last Irish bishop of Clonard, to the monastery of St. Thomas the Martyr, Dublin. ${ }^{1}$ They are scattered over the three deaneries of Dunshaughlin, Skreen and Trim. Thus Eugenius had absorbed into his diocese the bishoprics of those three places. Another document tells us that this same Eugenius consecrated the church of Duleek ; ${ }^{2}$ which implies that the diocese of Dulcek was also suppressed. 'Thus by Ir9I, the year of Eugenius's death -within eighty years of the Synod of Rathbreasail, and before the Anglo-Normans had captured the ecclesiastical domination of Meath-the diocese of Clonard had expanded to four times its original size. Its bishop ruled the whole area of the modern county of Meath which lies south of the Boyne and Blackwater.

Simon Rochfort, the first English bishop, stretched his arm further. We have a charter of his, which may be dated before I 202, confirming to St. Thomas's Abbey a number of churches in his diocese. ${ }^{3}$ It includes most, if not all, of the churches granted by his predecessor, but adds others. Among these are some in the deanery of Slane. The bishopric of Slane had been absorbed.

The rapid extension of his diocese towards the north

J R.T.A. p. 269 .

2 Ibid. p. 259.

${ }^{3}$ Ilid. p. 24 I. 
suggested to Rochfort the desirability of having for his healquarters a more central place than Clonard. So in I 202 he translated the see to Newtown, near 'Trim, ${ }^{1}$ and began to call himself Bishop of Meath. Ten years later, as we know, this "impudent bishop" captured the diocese of Kells." The bishop of Meath (no longer of Clonard) from his see at Newtown had the oversight of nearly the whole of the modern county. Within the confines of his diocese were the seven older dioceses of Clonard, Dunshaughlin, Skreen, Trim, I)uleek, Slane and Kells. This was probably the whole of the castern diocese as designed by the Synod of Usnagh.

But the policy of amnexation still went forward apace. Another document enables us to measure the progress of half a century. It is a concordat concerning metropolitical visitations, between the archbishop of Armagh and Rochfort's third successor, Ingh de Tachmon. It is dated $9^{\text {th }} A$ pril, $1265 .^{3}$ The tenor of the concordat does not concern us: it is important for our purpose because it proves that in $\mathrm{I}_{2} \mathrm{C}_{1} 5$ there were eleven rural deaneries in the diocese of Meath. Four more petty dioceses had been suppressed, Mullingar, Loxewdy, Ardnurcher and Fore. The diocese was co-extensive with that of the present day, except that the diocese of Clonmacnoise-as small in 1265 as it had been in I 100 -was not yet brought in.

Clonmacnoise preserved its independence three centuries longer. It was incorporated with Meath in 1569 . Thus at length the dream of the fathers of Rathbreasail was fulfilled. There were two dioceses in the ancient kingdom of Meath-Meath and Kilmore. But neither 1 Cal. of Papal Letters, v. 75. For date see Cal. of Documents,
1reland, i. I6S.

2 See 1). xxviii, note $I$.

3 K. A. p. 7 I. 
Duleek nor Clonard nor Clonmacnoise was a see. From that day to this, in fact, the diocese of Meath has had no see. And the boundary which parts Meath from Kilmore is very different from the line which the fathers of Rathbreasail drew between the dioceses of Clonard and Duleek, or that which the assembly of Usnagh drew between Clonmacnoise and Clonard.

\section{IV.-St. Malachy's Part in The Reformation}

It is not possible, within the limits of this Introduction, to follow the later stages of the Reformation movement in detail. In the present section I confine myself to the part which St. Malachy played in its development.

Malachy was born at Armagh in 1095. He was therefore a mere boy when the Synod of Rathbreasail met. At the dawn of his manhood he became the disciple of the recluse Imar O'Hagan. Imar was in sympathy with the aims of the reformers, and it was probably through his influence that Malachy became imbued with their principles. He soon attracted the notice of Cellach, and was by him ordained deacon. He was advanced to the priesthood about i i ig. Shortly afterwards Cellach made the young priest his vicar. For the next year or two it was Malachy's duty to administer the diocese of Armagh; and he did so in the most effective-indeed revolutionary-fashion. He evidently let no man despise his youth. His purpose, as his biographer tells us, was "to root out barbarous rites, to plant the rites of the Church." "He established in all the churches the apostolic sanctions and the decrees of the holy fathers, and especially the customs of the Holy Roman Church." He introduced the Roman method of chanting the services of the canonical hours. "He instituted anew Confession, Confirmation, the Marriage contract, of all 
of which those over whom he was placed were either ignorant or negligent." In a word, Malachy showed himself an ardent reformer. ${ }^{1}$

One wonders how, even with the assistance of Cellach and Imar, a young man who had never left Armagh could have already become sufficiently acquainted with the usages of other churches to carry out these sweeping measures. Perhaps his zeal was not always according to knowledge. But he soon became aware of his limitations, and determined to seek instruction. With the consent of Cellach and Imar he betook himself to Malchus, who had by this time retired from the archbishopric of Cashel and was settled at Lismore. There Malachy spent three years. During that period he doubtless increased his knowledge of Roman customs and principles. But he did more. Cormac MacCarthy, son of the king of Desmond, was then a refugee in the monastery of Malchus. Between Cormac and Malachy there grew up a friendship, which proved in later years of much advantage to the reforming cause. ${ }^{2}$

But at length Malachy's presence was urgently needed in the north, and he was recalled by Cellach and Imar. What had happened was this. The coarb of St. Comgall at Bangor, the principal religious site in the north-east of Ireland, had lately died. Since he ended his days at Lismore, it may be assumed that he was a friend of Malchus, and of the movement with which he was identified. At any rate his successor, who was Malachy's uncle, expressed his willingness to surrender his office and the site of the monastery to his nephew. ${ }^{3}$ Here was an opportunity to carry into effect one of the canons of Rathbreasail, which had hitherto

1 Life, $\$ \$ 4-7$.

2 life, s\$ 8 f., and p. $2 \mathrm{I}$, note $\mathrm{I}$.

3 See Life, §I 2 , and p. 27, note 1. 
been a dead letter, by establishing the diocese of Connor. Cellach, duly elected coarb of Patrick, and consecrated bishop, had no doubt been able to organize the diocese of Armagh in accordance with the Rathbreasail scheme. In like manner such a man as Malachy, enjoying the prestige which belonged to the coarb of Comgall, if consecrated bishop, would probably succeed in organizing the diocese of Connor. So in I I24 Malachy journeyed to Bangor, was installed as abbot, and was made bishop by Cellach. ${ }^{1}$ He administered his diocese with the same vigour which had already characterized his work at Armagh. But it is interesting to observe how closely he conformed to the old Irish type of bishop, in spite of his Roman proclivities. At heart he was far less bishop of Connor than coarb of Comgall, abbot of Bangor. Indeed, in strictness, he had no right to the title "bishop of Connor"; for Connor was not his see. He made Bangor his headquarters. ${ }^{2}$ Doubtless Malachy preferred Bangor to the nominal see, because it was consecrated by centuries of sacred memories, and because as yet he could not place the office of bishop above that of abbot. He ruled his great newly formed diocese, or as much of it as he succeeded in ruling, from its remotest corner on the sea shore, as Aidan ruled Northumbria from Holy Island. There he lived among his brethren, of whom he gathered a great company. There was no provision for his mensa, for he was "a lover of poverty." He practised austere asceticism. Yet he was an active missionary. He travelled incessantly through the diocese, but always on foot, visiting the towns, and roaming about the country parts, surrounded by his disciples. He preached to the people whom he met on his way. ${ }^{3}$ Nothing could be

1 Sie Lifi, \$16, and notes.

${ }^{3}$ Life, $\$ \$ 16,17$.

${ }^{2}$ p. 33 , note 1. 
more unlike a medieval bishop of the ordinary kind. At every point we are reminded of the labours of Aidan and Ceadd and Cedd as they are described by Bede. But we may be sure that it was precisely because Malachy was coarb of Bangor, because he lived according to the ancient Irish ideal of sainthood, that he secured the obedience of the people of his diocese.

In such work as I have mentioned Malachy was engaged from in 24 to I 127 . In the latter year he was driven out of Bangor by Conor O'Loughlin, king of the north of Ireland, and a second time betook himself to Lismore. There he again met Cormac MacCarthy, for that unfortunate prince was once more taking sanctuary with Malchus. He had succeeded a little while before to the throne of Desmond, but had been driven out by 'Turlough O'Conor, who made his brother king in his stead. But after a few months, persuaded by the entreaties of Malchus and Malachy, and aided by the arms of Conor O'Brien, king of Thomond, a nephew of Murtough, Anselm's correspondent, he made a successful attempt to regain his kingdom. ${ }^{1}$ Then Malachy moved on to Iveragh in the County Kerry, and there, under Cormac's patronage, he founded a new monastery for his community. ${ }^{2}$ Once again Cormac has friendly intercourse with Malachy, and another O'Brien is on good terms with the reformers.

It was at Iveragh, two years later, that Malachy received news of the death of Archbishop Cellach. ${ }^{3}$ It was an announcement which must have caused great anxiety to him and his friends. Who was to succeed to the primacy?

The importance of the question will become manifest if we recall the progress which had already been made

1 See Life, \$ 9, and notes.

2 Life, ${ }_{1}$ S.

\footnotetext{
3 llid. \$ 19.
} 
at Armagh, and what still remained to be done. When Cellach was elected abbot in 1105 , and in the following year was consecrated bishop, a great point had been gained. For the first time for $5_{5}$ o years the church of Armagh had a bishop as its ruler. We may suppose that Cellach soon organized the diocese, the limits of which were fixed at Rathbreasail. But whatever Gilbert or Malchus might hold as to the source of his authority, we cannot imagine that the members of the Church in the diocese based their allegiance to him on any other ground than the fact that he was their abbot and the coarb of Patrick. That he was a bishop added nothing, in their view, to his claims. Moreover Cellach belonged to the family which had long supplied Armagh with abbots. The abuse of hereditary succession had not disappeared with his appointment. ${ }^{1}$ If his successor was chosen in the time-honoured way, a member of the coarbial family would certainly be selected, and in all probability he would be a layman, who would not accejt episcopal orders. In a word, all that had been achieved by the reformers at the most important ecclesiastical centre in Ireland would be undone.

Cellach had foreseen this, and accordingly he determined to nominate Malachy as his successor. "With the authority of Patrick" he laid upon the nobles, and especially upon "the two kings of Munster," the obligation of securing that his wish should be carried into effect. The two kings who were thus charged with a difficult duty were Conor O'Brien, king of 'Thomond, the principal representative of the O'Briens, and Cormac MacCarthy, king of Desmond, Malachy's friend.

From Cellach's point of view the choice of a successor which he had made was a wise one. Malachy was as zealous a reformer as himself. He was a man of unusual

1 See p. $\mathrm{xv}$, and Additional Note 13. 
ability and force of character. Besides, he was possessed of a personal charm which might in time disarm opposition. He was already a bishop; therefore, if he were once seated in the chair of Patrick, the question whether the new coarb should be consecrated would not arise. More important still, he was not of the coarbial stock; with his entry into the see the scandal of hereditary succession would come to an end.

But it was not to be expected that the appointment would be accepted without strong protest; and at the moment there seemed little prospect that the scheme of Cellach would attain fruition. There is no need to enter into the details of the fierce struggle that ensued. It is dealt with elsewhere. ${ }^{1}$ Suffice it to say that by 1137 , with the aid of O'Brien and MacCarthy, and apparently with assistance also from Donough O'Carroll, king of Oriel, he was undisputed coarb of Patrick and archbishop of Armagh. The victory was won, and an immense stride had been made in the Reformation movement.

But Malachy had no mind to spend the rest of his life at Armagh. Five years before, as the condition of his entry into the fray, he had stipulated that as soon as he had been accepted as archbishop he should resign the see and return to his beloved Bangor. So in II 37 he nominated and consecrated Gelasius as his successor in the primacy, and "returned to his former parish, but not to Connor." Let me explain this enigmatical statement. Malachy had had some years' experience of the people of the diocese of Connor, whom St. Bernard gently describes as "not men but beasts." $\mathrm{He}$ had doubtless discovered that the district which it included could not be ruled by a single bishop. In fact it consisted of two tribal territories, Dál Araide in the north,

1 Life, \$§ 20-3r, with notes, and Additimal Note C. 
and Ulaid in the south; and the two tribes which inhabited them were usually engaged in mutual war. He decided that it should be divided into two dioceses. He consecrated a bishop for Dál Araide, with his see at Connor, and himself resumed the oversight of Ulaid, with his see at Bangor. ${ }^{1}$ 'Thus originated the present dioceses of Down and Connor. In Malachy's time the boundary between them seems to have run west from Larne. In the course of centuries it has shifted further south.

This division was a direct violation of the letter of the ordinance of Rathbreasail ; but it did not contravene its spirit. In the letter, which ignored the civil divisions of the country, the ordinance could not be obeyed. Malachy adopted a scheme which secured the permanent rule of diocesan bishops in the district.

Malachy was now, and continued to be till his death, bishop of Down, or more strictly of Bangor; in the current Irish phrase bishop of Ulaid. But his activities already extended beyond his diocese. Within the next two years he succeeded in establishing in actual fact another diocese which till now had existed only on paper. It was that which the Synod of Rathbreasail had called the diocese of Clogher, and which we know by the same name; but which for sixty years or more bore the name of the diocese of Oriel.

That we may understand his action let us return for a moment to the five Ulster dioceses as plarmed at Rathbreasail. In four of them regard was paid to tribal boundaries. The diocese of Raphoe corresponded to Tír Conaill, Derry to Tír Eoghain, Armagh to Oriel, while Connor comprehended the two territories of Dál Araide and Ulaid. The diocese of Clogher was of necessity the remainder of the province. If it 
coincided with a tribal district, that could only happen by chance. In fact it did not. It was much smaller than the other dioceses. It embraced only the present barony of Clogher in the county of Tyrone, and the portion of Fermanagh lying between it and the Erne waterway. It had within it no element of cohesion. It was most unlikely that it could ever constitute an ecclesiastical unit, governed by a bishop.

Nevertheless an attempt seems to have been made to consolidate it as a diocese a few years after Rathbreasail ; as might have been expected, without success. A bishop of Clogher, who apparently had no diocese, died in 1I35. He was succeeded by Christian O'Morgair, brother of Malachy. He was probably nominated and consecrated by his brother, who was then titular archbishop of Armagh. Now about this time Donough O'Carroll, king of Oriel, joined the ranks of the reformers, as we may suppose under the influence of Malachy. His kingdom included the little diocese of Clogher; but the main part of it consisted of the present counties of Monaghan and Louth. Accordingly a bold stroke of policy was conceived and carried out. The diocese of Clogher was enlarged so as to cover the greater part of O'Carroll's kingdom. For this purpose the archbishop of Armagh surrendered a large part of his diocese - the whole of Monaghan and Louth. Then Christian moved his see from Clogher to the spot now occupied by the village of Louth. Thus there was constituted a new diocese, which included the Rathbreasail diocese of Clogher, but was four times its size, and had its see at Louth. It was known as the diocese of Oriel. In all this we see plainly the hand of Malachy. Not long after the removal of the see Christian died, and Malachy selected and consecrated his successor, one Edan O'Kelly. O'Kelly had a long episcopate, from I 139 to 
1182 ; and with the help of O'Carroll he organized his diocese, and gave it a cathedral at Louth with a chapter of Augustinian canons. ${ }^{1}$ Once again Malachy was the maker of a diocese; and once again, in the interest of stability, he transgressed the letter of the Rathbreasail canons, while fulfilling their spirit. It was not till after the coming of the Anglo-Normans that the see was brought back to Clogher. Subsequently the county of Louth reverted to Armagh, and the diocese extended to the west. About the year r 250 its boundaries cause to be what they now are. ${ }^{2}$

In 1139 , after settling the affairs of the diocese of Oriel, Malachy left Ireland on an important mission. It will be rentembered that Gilbert had declared that no archbishop could exereise his functions till the lope had sent him the pall. 'That was the current doctrine of the agre. Now neither Cellach, nor Malachy, nor Gelasius, nor Malchus, nor his successor at Cashel, had received that ornament. They had therefore, in the strict sense, no right to the title of archbishop. Malachy resolved to make request to the Pope in person for palls for the two Irish metropolitans. So he set out from Bangor for Rome. ${ }^{3}$ Of his journey it is unnecessary to say anything here. ${ }^{4}$

At Rome Malachy was received by Pope Innocent II.

1 See Lifi, \$ $3 t$ and notes.

2 for a fuller account of the beginnings of the diocese of Clogher see L..t./. vol. iv. pp. I29-159. To the reasons there given for letieving that Christian translerred the see from Clogher to Louth should be added the fact that in Tundale (p. 5+4) he is called Lustamensis episcopus.

3 Life, \$\$ 33,34 .

4 Ibir. $\$ 35-41$. The reader may be reminded, however, that the two visits of Malachy to Clairvaus, in the course of this journey, producerl the friendship between him and St. Ijernard, wlich had its twofold issue in the composition of the important documents included in this volume, and the introduction of the Cistercian Order into lreland. 
with great honour. He confirmed the erection of the metropolitan see of Cashel. But he politely declined to grant the palls. They must be demanded, he said, by a council of the bishops, clergy and magnates; and then they would be given.

But if the Pope refused Malachy's request, he bestowed on him an office, the securing of which we may conjecture to have been one of the purposes of his visit to Rome, though St. Bernard does not say so. Gilbert, now old and infirm, had resigned the see of Limerick, and with it his legatine commission. Innocent made Malachy papal legate in his stead. ${ }^{1}$

Thus Malachy returned to Ireland, still bishop of Down indeed, but virtually chief prelate of the Irish Church. For the following eight years he laboured with zeal and vigour. St. Bernard unfortunately gives little information concerning the details of his administrative work as legate. But he relates one incident which suggests that in this period Malachy was instrumental in founding another diocese. He nominated and consecrated the first known bishop of Cork, ${ }^{2}$ not improbably with the intention that he should unite in his own person the two offices of coarb of Barre, founder of Cork, and diocesan bishop.

And in this connexion it is worth noticing that he was evidently on friendly terms with Nehemiah, the first known bishop of the neighbouring diocese of Cloync. ${ }^{3}$ If that diocese was also founded by him he once again violated the letter of the Rathbreasail canons, for by them Cloyne was included in the diocese of Enly.

In $\mathrm{I}_{4} 8$ Malachy convened a synod at Inispatrick, an island opposite Skerries, Co. Dublin. This synod clemanded the palls in due form, and scnt Malachy to

1 Life, $\$ 3$ s.

$2 \$ 5 \mathrm{I}$.

$3 \$ 47$. 
obtain them. But he got no further on his journey than Clairvaux. There, after celebrating Mass on St. Luke's Day, he was taken ill of a fever; and there a fortnight later he died in the arms of St. Bernard, on All Souls' Day, end November, I $4.8 .{ }^{1}$

Nevertheless the palls came. They were brought to Ireland by a legate specially commissioned by Pope Eugenius III., John Paparo, cardinal priest of St. Laurence. A synod was held at Kells to receive them in March 1152,2 of which the joint presidents were Paparo, as legatus a latere, and Christian, first abbot of Mellifont, and now bishop of Lismore, who had lately succeeded Malachy as legatus natus.

Of this synod Keating gives a short account, abridged from the Annals of Clonenagrh, ${ }^{3}$ from which he had also derived his knowledge of the proceedings at Rathbreasail. He preserves a list of the bishops who attended. It includes twenty-two names, if we count two vicars who represented absent bishops. There were besides, as Keating informs us, five bishops-elect. And there was certainly one bishop of a diocese who was neither present nor represented, Edan O'Kelly, bishop of Oriel. So it appears that in 1152 there were at least twentyeight clioceses in Ireland-a number considerably larger than was contemplated at Rathbreasail. The increase in number is partly accounted for by the presence of the bishop of the recently formed diocese of Kilmore, the division of the diocese of Connor into Connor and Down,

\section{Life, $\$ \$ 67-75$.}

2 There was no unnecessary delay on the part of the Pope in sending the palls. After the death of Malachy a deputation was sent from Ireland to Rome to demanil them. Paparo set out to confer them, and reached England in 1150 ; but King Stephen would not allow him to proceed to Ireland except on terms which he could not accept. (John of Hexham, p. 326 ; Historia Pontificalis in M.G.H. xx. 539 f.)

${ }^{3}$ Vol. iii. p. $313 \mathrm{ff}$. 
and, a most striking addition, the inclusion of Gregory, bishop of Dublin, among the assembled prelates. It is remarkable that the bishop of Kells is not mentioned, though the synod was held in his own city. How was the bishop of Dublin induced to throw in his lot with the Irish Church? We shall see in a moment.

Much business was transacted at this Synod. But that which concerns us most nearly is the giving of the palls. Cardinal Paparo brought the Irish bishops more than they had asked for ; more indeed than they desired. He presented, not two palls but four, Dublin and Tuam, as well as Armagh and Cashel, being recognized as archiepiscopal sees. This excessive generosity caused much displeasure among the Irish bishops. "For Ireland," says Keating, apparently paraphrasing the Annals of Clonenagh, "thought it enough to have a pall in the church of Armagh and a pall in Cashel; and particularly it was in spite of the church of Armagh and the church of Down that the other palls were given." The cause of this discontent is not far to seek. The chief gravamen no doubt was that Dublin was included among the four. The constant friction which had subsisted for many years between the diocese of I)ublin and the Irish Church sufficiently explains the indignation of the archbishop of Armagh, aggravated by the fact that the creation of new archbishops imposed a limit upon his authority. It also enables us to understand why his displeasure was shared by the Irish generally. That a see whose bishops had behaved so haughtily in the past should, at the very moment of its entrance into the Irish Church, receive so signal an honour, long denied to Armagh and Cashel, and that in the person of its bishop it should be given jurisdiction over bishops whom till now it had treated with contempt, could not but be regarded as unreasonable, or even insulting. 
But on the other hand, recalling the early history of the Church in Dublin, we can comprehend why, in spite of all this, special favour was bestowed upon it. Dublin, as we have seen, was a not too submissive suffragan of Canterbury. Its ambition was that its bishop should have the status of a metropolitan. The opportunity had come for gratifying its desire, and at the same time bringing it under the Irish ecclesiastical régime. The pall at once separated it from Canterbury and united it with Ireland. It was the price paid for its submission to the Primacy of Armagh. Gregory therefore became archbishop of Dublin, and had the right-which his predeccssor had long before illegally assumed-to have the cross carried before him. With the gift of the pall Paparo bestowed upon him "the principal part of the bishopric of Glendalough as his diocese," promising hin the remainder on the death of the bishop who then ruled it. All this was done, we are told, because it was fitting that the place "in which from ancient time had been the royal seat and head of Ireland," should be made a metropolitan see. ${ }^{1}$

There was at last one Church in Ireland, which embraced within it not only the Celtic parts of the island, but all the Danish dioceses as well. And the whole Church was ruled by the bishops. The Reformation may not have been complete in every detail-there was indeed much left for the Anglo-Normans to do-but the Synod of Kells had set the crown on the work of the Irish reformers. And this consummation was mainly due to the wisdom and the untiring zeal of st. Malachy of Armagh.

A few words more will suffice to complete this too

1 Sice Letter of Pope Innocent III. to IJenry of London, 6 Oct. 1216, in Crode Milii (erl. (iillert), P. I I. 
lengthy introduction. The Life of Mandhy was certininly written before the Synod of Kells met in March i I52; for Christian, who attended the synod as bishop of Lismore, is spoken of in the Lifi as abbot of Mellifont.: Its carliest possible date is a couple of months after Malachy's death. The ignorance displayed in $\$ 69^{2}$ of - the movements of the l'ope in 11.48 is so inexplicable on the assumption of a later date that it may be assigned to January $149 .^{3}$ In the following translation the text printed by de Backer ${ }^{4}$ is used, with the exception of a few sentences which have been emended. It does not differ to any great extent from that of Mabillon.5 Following de Backer I have divided the text into chapters, in accordance with the MSS.; but Mabillon's sections have been retained, as more convenient for reference, the numbers of de Backer's sections being added within brackets.

By way of illustration four letters of St. Bermard and his two sermons on St. Malachy have been added. 'They are translated from Mabillon's edition," with some corrections. The dates of these documents are discussed below. ${ }^{7}$

1 กร 14,52 .

2 See p. I22, mote I.

${ }^{3}$ Cp. K.I.K. xxxv. $259 \mathrm{ff}$. This conchusion is comolora'cel hy Tundale's Vision, which seems to have been written early in II 49 (see Fiedel and lieyer, La l'ision de Tindth, Im, pl. vi-xii; Rev. Celt. xxviii. 4II). The writer speaks of the Life of Matachy as already written, and in course of transcription (Tundale, p. 5 , 'cuins uitam ... Bernhardus . . transscrilit'). He may have derived his erronenus statement (itial.) that Pope Eugenius went to Rome in the year of Nalachy's death from St. Bernard: sce p. $\mathbf{3 2 2}$, note $\mathbf{I}$.

4 AA. S.S., Nov., xii. I , $143^{-1} 46$.

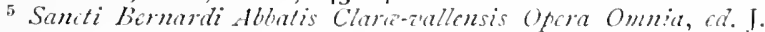
Mabillon, I 89 , vol. i. 2, cols. I465-1524. Keprinte l I. L. (Ixxxii. J073-11 I 8.

"Op.cit. i. 2, 222 I $223 \mathrm{I}$; i. I, 31I, 356, 357, 37.1 ; reprinterl in J.L. clxxxiii. is I 490 ; clxxxii. 515 f., 558 f., 579 f.

7 see notes in PI) I 3 I, I 33 f., I 37 . 14I, I 57 . 
St. Bernard's numerous quotations from the Bible and other sources are printed in italics, so far as I have recognized them. 'The scriptural allusions are given as nearly as possible in the words of the Authorized (in the Apocryphal books the Revised) Version, though at times they do not agree with the V'ulgate Latin. Where it has been found necessary to depart from their renderings, the symbol "vg." follows the references in the footnotes.

I desire to make grateful acknowledgement of help received from my friends, of whom I must specially mention Dr. L. C. Purser, Senior Fellow of Trinity College, I ublin, Mr. R. I. Best, the Rev. J. E. I. Oulton, the Rev. Dr. J. M. Harden and the Rev. Canon C. P. Price. My wife assisted me in the preparation of the index. 


\section{THE LIFE OF ST. MALACHY}

\section{PREFACE}

I. It is indeed always worth while to portray the illustrious lives of the saints, that they may serve as a mirror and an example, and give, as it were, a relish to the life of men on earth. For by this means in some sort they live among us, even after death, ${ }^{1}$ and many of those who are dead athile they liz'e ${ }^{2}$ are challenged and recalled by them to true life. But now especially is there need for it because holiness is rare, and it is plain that our age is lacking in men. So greatly, in truth, do we perceive that lack to have increased in our day that none can doubt that we are smitten by that saying, Because iniquity shall abound the love of many shall acax cold ${ }^{3}$ and, as I suppose, he has come or is at hand of whom it is written, Want shall go before his face. ${ }^{4}$ If I mistake not, Antichrist is he whom famine and sterility of all good both precedes and accompanies. Whether therefore it is the herald of one now present or the harbinger of one who shall come inmediately, the reant is evident. I speak not of the crowd, I speak not of the vile multitude of the children of this zorld: ${ }^{5}$ I would have you lift up your eyes upon the very pillars ${ }^{6}$ of the Church. Whom can you show me, even of the number of those who

3 Ecclus. xlviii. 12 (vg.).

3 Matt. xxiv. 12.

5 Luke xvi. 8 .

2 I Tim. v. 6. Cp. Rev. iii. I.

Jol, xli. 22 (vg.).

Gial. ii. 9 . 
seem to be given for a light to the Gentiles, ${ }^{1}$ that in his lofty station is not rather a smoking wick than a blazing lamp? And, says One, if the light that is in thee be darkness, howe great is that darkness! ${ }^{2}$ Unless perchance, which I do not believe, you will say that they shine who suppose that gain is godliness; ${ }^{3}$ who in the Lord's inheritance seek not the things anllich are the Lord's, but rather their onen. Why do I say their onen? He would be perfect and holy, even while he seeks his own and retains his own, who should restrain his heart and hands from the things of others. But let him remember, who seems to himself to have advanced perhaps thus far, that the same degree of holiness is demanded even of a gentile. ${ }^{5}$ Are not soldiers bidden to b' content with their zages that they may be saved? ${ }^{\circ}$ But it is a great thing for a doctor of the Church if he be as one of the soldiers; or, if, in truth (as the prophet speaks to their reproach), it be as with the people so with the priest. ${ }^{7}$ Hideous! Is it so indeed? Is he rightly to be esteemed highest who, falling from the highest rank can scarce cleave to the lowest, that he be not engulfed in the abyss? Yet how rare is even such a man among the clergy! Whom, likewise, do you give me who is content with necessaries, who despises superfluities? Yet the law has been enjoined beforehand by the Apostles on the successors of the Apostles, Haring food and raiment, let us be therezeith content. ${ }^{8}$ Where is this rule? We see it in books, but not in men. But you have [the saying] about the righteous man, that the law of his God is in his heart, ${ }^{9}$ not in a codex. Nur is that the standard of perfection.

1 Isa. xlix. 6.

3 I Tim. vi. 5 .

5 C P. Matt. v. 47.

7 Isa. xxiv. 2 ; IIos. iv. 9 (inexact quotation).

${ }^{8} 1$ Tim. vi. $S$ (inexact quolation).
2 Matt. vi. 23.

4 I'hil. ii. 21 ; I Cor. xiii. 5.

6 Luke iii. 14.

9 l's, xxxrii, 3 I. 
The perfect man is ready to forgo even necessaries. liut that is beside the mark. ${ }^{1}$ Would that some limit were set on superfluous things! Would that our desires were not infinite! But what? l'erhaps you might find one who can achieve this. It would indeed be difficult ; but [if we find him] see what we have done. We were seeking for a very good man, a deliverer of many; and lo, we have labour to discover one who can save himself. The very good man to-day is one who is not utterly bad.

2. Wherefore, since the godly man has ceased ${ }^{2}$ from the earth, it seems to me that I do not employ myself to no purpose when I recall to our midst, from among those who were redeemed from the earth, ${ }^{3}$ Bishop Malachy, a man truly holy, and a man, too, of our own time, of singular wisdom and virtue. He zeres a lumining and a shining light ${ }^{\mathbf{4}}$ and it has not been quenched, but only removed. Who would with good right be angry with me if I move it back again? Yes indeed, neither the men of my own age, nor any succeeding generation should be wanting in gratitude to me if by my pen I recall one whom the course of nature has borne away; if I restore to the world one of whom the world ze'as not zeorthy; ${ }^{5}$ if I preserve for the memory of men one zolose memory may be blessed ${ }^{6}$ to all who shall deign to read; if while I rouse my sleeping friend, the voice of the turtle be heard in our land ${ }^{2}$ saying, Lo, I am reith you alzerty, even unto the end of the zerorld. ${ }^{8}$ Then again, he was buried among

1 Gratis.

${ }^{3}$ Rev. xiv. 3 .

${ }^{5}$ Heb. xi. 38.

7 Cant. ii. 12. For the meaning compare Cint. lix. 3: The voice of the turtle "is a sign that winter is past, proclaiming nevertheless that the time of pruning has come . . . The voice, more like one who groans than one who sings, admonishes us of our pilgrimage." After Eugenius III. had visited Clairvaux S1. Bernard wrote, "The voice of the turtle has been heard in our chapter. We had greal joy and delight."

Matt. xxviii. 20.
2 Ps. xii. r.

4 Joln v. 35 .

6 Ficclus $\mathrm{xly}, \mathrm{t}$ (Ep. 273.) 
us $;^{1}$ this duty is eminently ours. Nay, is it not mine, inasmuch as that holy man included me among his special friends, and in such regard that I may believe that 1 was second to none in that respect of glory ? ${ }^{2}$ Nor do I find that intercourse with holiness so eminent misses its reward; I have already received the firstfrtits. He was near the end; nay, rather, near the beginning, according to the saying, when a man hath finished then is he but at the beginning. ${ }^{3}$ I ran to him that the blessing of him that zeas ready to die might come upon me. Already he could not move his other limbs; but, mighty to give blessing, he raised his hands upon my head and blessed me. ${ }^{5}$ I have inherited the blessing ; ${ }^{6}$ how then can I be silent about him? Finally, you enjoin me to undertake this task, Abbot Congan, ${ }^{7}$ my reverend brother and sweet friend, and with you also (as you write from Ireland) all that Church of the saints ${ }^{8}$ to which you belong. ${ }^{9}$ I obey with a will, the more so because you ask

1 That is, at Clairvaux. See $\S 75$.

2 Apparently a confused reference to 2 Cor. iii. 10 ; xi. 17 (vs.).

3 Ecclus. xviii. 7 (inexact quotation).

5 See $\$ 73$, end.

"Joh xxix. 13.

- This abbot, to whom the Life is dedicated, belonged to the Cistercian Order, as the words "reverend brother" imply. He may therefore be idenified with Congan, abbot of the Cistercian monastery of the Suir, mentioned in $\S 64$. That he was personally known to St. Bernard is clear; and it is probable that he was one of the Irishmen who by Malachy's desire were instructed at Clairvaux (\$39). Thady Dowling (Annals, s.a. I147) idlentifies him with "Cogganus," abbot of Killeshin, near Carlow, stating on the authority of Nicholas Maguire that he wrote the sista of Malachy and Bernard. Thougl this statement is probal,y not accurate, it is possible that our Congan was abbot of Killeshin before he became a Cistercian.

8 Ecclus. xxxi. I I (vg.).

9 Vestra illa omnis ecclesia sanctorum. We should perhaps render, "the whole church of holy persons over which you preside," $i$. $e$. Congan's convent. Elsewhere in the Life, ecclesia is used for a local community, such as the church of Armagh (\$20, etc). But see Serm. i. $\$$. Vacandard understands the phrase to mean "the Cistercian communities of Ireland" (K.Q.H. lii. 48). 
not panegyric but narrative. I shall endeavour that it may be chaste and clear, informing the devout, and not wearying the fastidious. At any rate the truth of my narrative is assured, since it has been communicated by you ; ${ }^{1}$ and beyond doubt you assert nothing but things of which you have most certain information.

Here ends the Prologiue.

1 lobis (pl.); i. c. Congan and others in Ireland. 
Here begins the life of Malude the Bishop

\section{CHAPTER I}

The iarly life of Malachy. Hating been admithd to Holy Orde's he ussociales with Malchus

1. Ouk Malachy, born in Ireland, ${ }^{1}$ of a bar-

I095. barous people, was brought up there, and there received his education. But from the barbarism of his bith he contracted no taint, any more than the fishes of the sea from their native salt. liut how delightful to reflect, that uncultured barbarism should have pro. duced for us so worthy a fellow-citizen with the sainls and member of the household of God.3. He who brings honcy out of the rock and oil out of the Rinty rock 4 Himself did this. His parents, ${ }^{5}$ however, were great

1 Malachy was born in 1095, before Novemler. See below, 1. 13 . n. 2 .

${ }_{2}^{2}$ trlamum, citizen like.

4 I teut, xxxii. I 3 .

5. A. make the curious statement that "Mat Maedoc o Mongair and his father Mughron" died in 1102 . This is perhaps sufficient evilence that Malachy's father was Mughron Ua Morgair, "ho according to $A . U$. was ard for lésind (chief professor) at Armagh, and died at Nungret, Co. Limerick, on Octoler 5, I IOz. Malachy was then only seven or eight years of age. Thus we may account for the large part taken by his mother in his early education. But a poem attributed to Malachy (L.B.SS) calls his father Dermot. The form of the surname varies. It is usually written Ua Morgair; l.ut A.T., A.I. (Ua Mongain), L.B. (l.c.), and the Yellow l; rok of Lecan (T.C.D. MS. H. 2. I6, p. 327 c), have Ua Mongair. The form Ua Morgair is cerainly right, for it appears in the contemporary Book of Leinster (R.I.A. xxxv. 355$360)$; ard Ua Nongair obriously arose out of it through confusion of the similar letters $r$ and $n$. The name must hove been unfamiliar, if it land not died out, when the mislake was made. 
both by descent and in power, like unto the name of the great men that are in the earth. ${ }^{\mathbf{1}}$ Moreover his mother, ${ }^{2}$ more noble in mind than in blo sd, took pains, in the very beginning of his ways, ${ }^{3}$ to show to her child the ways of life, ${ }^{\mathbf{4}}$ esteeming this knowledge of more value to him than the empty knowledge of the learning of this world. For both, however, he had aptitude in proportion to his age. In the schools he was taught learning, at home the fear of the Lord, ${ }^{5}$ and by daily progress he duly responded to both teacher and mother. ${ }^{6}$ For indeed he was endowed from the first with a good spirit, ${ }^{7}$ in virtue of which he was a docile boy and very lovable, wonderfully gracious to all in all things. But he was [now] drinking, instead of milk from the breast of a mother, the waters of saving wisdom, ${ }^{8}$ and day by day he was increasing in discretion. In discretion, shall I say, or in holiness? If I say both, I shall not regret it, for I should say the truth. ${ }^{\prime \prime}$ Ile behaved as an old man, a boy in years without a boy's playfulness. And when because of this he was regarded with reverence and astonishment by all, he was

Therefore we may accept Colgan's statement that the family was known as O'Dogherty in his day (Trias, P. 299). If so, they had probably only resumed an earlier surname: for according 10 MacFirbis (Royal Irish Academy Ns. 23 P. 1, p. 698) Malachy was of the same stock as Si. Nacl Bri;le, son of Tornan. The latter, as well as lhe O'Doghertys, were of the race of Conall Gulloan (Adamnan, Genealogy opp. p. 342).

12 Sam. vii. 9.

2 It is interesting to note the emplasis laid by St. Bernard on the influence of Malachy's mother on his life. How much lu himself owed to his mother Aleth is well known. See I.I'. i. 1, 2,9 , 10. Malachy's mother was probally a member of the family of O'Hanratty. See bclow, p. 27, n. 2.

3 Prov, viii. 22.

5 Ps. xxxiv. II.

- The description of Malachy's boyhool hy St. Bernard may be compared with that given of his own boyhood in I.P. i. 3. I1 was writlen before the Life of Malachy.

7 Neh. ix. 20; l's. cxliii. Io.

8 Ecclus. xv. 2, 3 ( $v_{0}^{*}$ ).

92 Cor. xii. 6. 
not found on that account, as commonly happens, more arrogant, but rather quiet and subdued in all meekness. ${ }^{1}$ Not impatient of rule, not shunning discipline, not averse from reading, not, therefore, eager for games-so especially dear to the heart of boys of that age. And he advanced beyond all of his own age 2 in that learning, at least, which suited his years. For in discipline of morals and advance in virtues in a short time he even outshone all his instructors. ${ }^{3}$ His unction, ${ }^{4}$ however, rather than his mother, was his teacher. Urged by it he exercised himself not slothfully also in divine things, to seek solitude, to anticipate vigils, ${ }^{5}$ to meditate in the law, ${ }^{6}$ to eat sparingly, to pray frequently, and (because on account of his studies he had not leisure to frequent the church, and from modesty would not) to lift up holy hands every. where $^{7}$ to heaven; but only where it could be done secretly-for already he was careful to avoid vainglory, that poison of virtues. ${ }^{8}$

2. There is a hamlet near the city in which the boy studied, ${ }^{9}$ whither his teacher was wont to go often, accompanied by him alone. When they were going there both together, as he related afterwards, he would step back, stop a moment, ${ }^{10}$ and standing behind his teacher, when he was not aware of it, spread forth his hands loward heaven, ${ }^{11}$ and quickly send forth a prayer, as if it were a dart; and, thus dissembling, once more would follow the teacher. By such a pious trick the boy often deceived him who was his companion as well as teacher. It is not possible to mention all the qualities which adorned his earlier years with the hue of a good natural disposition; we must hasten to greater and more useful
1 Eph. iv. 2.
2 Gal. i. I4.
4 I Johi ii. 20.
6 P's. i. 2.
3 Ps. cxix. 99.
8 Virus uirtutum.
5 Ps. Ixxvii. 4 (vg.).
${ }^{10} \mathrm{Cp}$. Virg. AEn. vi. 465.
7 I Tim. ii. 8.
9 Armagh. See $\$ 4$.
11 I Kings viii. 22, 54 . 
matters. One further incident, however, I relate because, in my judgenrent, it yielded a sign, not only of good, but also of great hope in the boy. Roused once on a time by the reputation of a certain teacher, famous in the studies which are called liberal, he went to him desiring to learn. For indeed he was now grasping after the last opportunities of boyhood, and was longing eagerly for such learning. But when he went into the house he saw the man playing with an awl, and with rapid strokes making furrows in the wall in some strange fashion. And shocked at the bare sight, because it smacked of levity, the serious boy dashed away from him, and did not care even to see him from that time forward. Thus, though an avid student of letters, as a lover of virtue he esteemed them lightly in comparison with that which was becoming. By sucl preliminary exercises the boy was being prepared for the conflict which awaited him in more advanced ${ }^{1}$ age: ; and already in his own person he was challenging the adversary. Such, then, was the boyhood of Malachy. Moreover he passed through his adolescence with like simplicity and purity; except that as years increased, there increased also for him wisdom and favour with God and man. ${ }^{2}$

3. From this time, that is, from his early adolescence, what was in the man $^{3}$ began to appear more plainly, and it came to be seen that the grace of God which was in him was not in vain. ${ }^{4}$ For the industrious young man, ${ }^{5}$ secing how the world lieth in wickedness, ${ }^{6}$ and considering what sort of spirit he had received, said within himself, "It is not the spirit of this world." What have the two in common? 8 One has no communion with the other any more than light with darkness. ${ }^{9}$ But my spirit

1 Fortioni.

4 I Cor. xv. 10.

7 I Cor. ii 12.
2 Luke ii. 40, 52.

5 I Kings xi. $2 S$.

${ }^{8}$ Cp. John ii. 4 (vg.).
3 John ii. 25.

6 I John v. 19.

92 Cor. vi. 14. 
is of God, and I know the things that are freely given me ${ }^{\mathrm{I}}$ in it. From it I have innocence of life till now, from it the ornament of continence, from it hunger for righteousness, ${ }^{2}$ from it also that glory of mine, by so much more secure because it is more secret, the testimony of my conscience. ${ }^{3}$ None of these is safe for me under the prince of this world. ${ }^{4}$ Then, I have this treasure in an earthen vessel. ${ }^{5}$ I must take heed lest it should strike against something and be broken, and the oil of gladness ${ }^{6}$ which I carry be poured out. And in truth it is most difficult not to strike against something amid the stones and rocks of this crooked and winding way and life. ${ }^{7}$ Must I thus in a moment lose together all the blessings of goodness with which I have been provented ${ }^{8}$ from the beginning? Rather do I resign them, and myself with them, to Hin from whom they come. Yea, and I am His. I lose my very soul ${ }^{9}$ for a time that I may not lose it for ever. And what I am and all that I have, where can they be as safe as in the hand of their Author? Who so concerned to preserve, so powerful to hold, so faithful to restore? He will preserve in safety. He will restore in good time. Without hesitation I give mysclf to serve Him by His gifts. I cannot lose aught of all that I spend on my labour of piety. Perchance I may even hope for some greater boon. He who gives freely is wont to repaly with usury. So it is. He will even heap up and increase vistue in my soul." 10

So he thought-and did; knowing that apart from deeds the thoughts of man are vanity. ${ }^{11}$

1 I Cor. ii. 12.

32 Cor. i. 12 (vg.).

52 Cor. iv. 7 .

7 Collect of Mass for Travellers.

9 Matt. x. 39.

10 Ps. cxxxviii. 3 (vg.).

11 I's. xciv. 11 .
2 Cp. Matt. v. 6.

4 John xiv. 30 , etc.

6 P's. $x l y .7$.

8 Ps. xxi. 3 . 
4. (3) There was a man in the city of Armagh, ${ }^{1}$ where Malachy was brought up-a holy man and of great austerity of life, a pitiless castigator of his body, ${ }^{2}$ who had a cell near the church. ${ }^{3}$ In it he abode, serving God with fastings and prayers day and night. ${ }^{*}$ To this man Malachy betook himself to receive a rule ${ }^{\mathbf{5}}$ of life from

c. III2. him, who had condemned himself while alive to such sepulture. And note his humility. From his earliest age he had had God as his teacher-there is no doubt of it-in the art of holiness; and behold,

1 His name was Imar (\$ 5). He was no doubt Imar O'Hlagan, who founded the monastery of St. l'aul and St. Peter at Armagh, and built a stone church for it which was consecrated on October 21, I I 26. It was placed, either at its foundation or subsequently, under the rule of the regular canons of St. Augustine. Imar died on pilgrimage at kome in $\mathrm{I}_{3} 34$, and is commemorated in Gorman on August $\mathbf{I}_{3}$, and in Usuard on November 12. He was at this time evidently leading the life of an anehoret. Reeves (Churches, p. 2\$) inferred from his Christian name that he had some Danish blood in his veins. There is no certain indication of Malachy's age when he became bis diseiple. But he hatd reached adolescence $(\$ 3)$, and was old enough to choose his own teaehers $(\$ 2)$. In II 2 he was seventeen years of age. We shall see that he long acknowledged Imar as his master : $\$ \$ 5,6,8,12,14,16$.

2 I Cor. ix. 27 (vg.).

3 That is, apparently, the great stone church (daimliac mír), on which Cellach put a shingle roof in 1125 . Aecording to Reeves (Churches, pp. I4, 2S) it was probably on the site of the present Cathedral, from which the Abbey of St. Paul and St. l'eter was distant $3_{3} 0$ yards to the north. It was the principal church of Armagh till r268. For an aceount of the life of such recluses as Imar the reader may be referred to B. MacCarthy, Codex PalatinoVaticanus No. $\mathcal{S}_{3} \circ$, p. 5 f.

${ }^{4}$ Luke ii. 37.

b Formam. The word, as used by St. Bernard, seems to include the two notions of rule and example. It wonll seem that Malachy received some sort of monastic rule from Imar. $\mathrm{Cp} . \S 7$, "his monastery," and the reference to "the first clay of his eonversion" in $\$ 43$. Both passages imply that he belonged to a religious order. So in $\$ 5$ he is said to have been before the other di-ciples of Imar "in conversion." On later oceasions he was suljeet to Imar's "command" $(\$ \$ 14,16)$. It is not improbable that the disciples who gathered round Imar were the nueleus of the community which he foumled at Armagh (note 1). If so, the inference is reasonable that Malachy beeame a regrular eanon of St. Aurrustine. 
he became once more the disciple of a man, himself a man meek and lowly in heart. ${ }^{1}$ If we did not know it, by this one deed he himself gave us proof of it. Let them read this who attempt to teach what they have not learned, heaping to themselves disciples, ${ }^{2}$ though they have never been disciples, blind leaders of the blind. ${ }^{3}$ Malachy, taught of God, ${ }^{4}$ none the less sought a man to be his teacher, and that carefully and wisely. By what better method, I ask, could he both give and receive a proof of his progress? * If the example of Malachy is for them a very small thing, ${ }^{5}$ let them consider the action of l'aul. Did not he judge that his Gospel, though he had not received it of man but from Christ, ${ }^{6}$ should be discussed with men, lest by any means he reas running or had run in vain? 7 Where he was not confident, neither am I. If any one be thus confident $^{8}$ let him take heed lest it be not so much confidence as rashness. But these matters belong to another time.

5. Now, however, the rumour of what had happened went through the city, and it was universally stirred by this new and unexpected event. All were amazed, and wondered at his virtue, all the more because it was unusual in a rude people. You would see that then thoughts were being revealed out of the hearts of many. ${ }^{9}$ The majority, considering the act from a human standpoint, were lamenting and grieving that a youth who was an object of love and delight to all had given himself up to such severe labours. Others, suspecting lightness on

1 Matt. xi, 29.

3 Matt. Xv. I4.

5 I Cor. iv. 3.

7 Gal. ii. 2.

8 I'rinted text, hoc scit. I read sit with $\mathrm{K}$ (hec sit), and two of rle Packer's MSS.

9 Luke ii. 35.
2 Cp. 2 Tim. iv. 3.

6 Gal. i. II, I 2.
4 Isa. liv. 13 ; John vi. 45. 
account of his age, doubted whether he would persevere, and feared a fall. Some, accusing him of rashness, were in fact highly indignant with him because he had undertaken a difficult task, beyond his age and strength, without consulting them. But without counsel he did nothing; for he had counsel from the prophet who says, It is good for a man that he bear the yoke in his youth, and adds, He sitteth alone and keepeth silence because he hath borne it upon him. ${ }^{1}$ The youth sat at the feet of Imar (for that was the man's name) and either learned obedience ${ }^{2}$ or showed that he had learnt it. He sat as one that was at rest, as meek, as humble. He sat and kept silence, ${ }^{3}$ knowing, as the prophet says, that silence is the ornament of righteousness. ${ }^{4}$ He sat as one that perseveres, he was silent as one that is modest, except that by that silence of his he was speaking, with holy David, in the ears of God: I am a youth and despised, yet do not I forget thy precepts. ${ }^{5}$ And for a time he sat alone, because he had neither companion nor example; for who before Malachy even thought of attempting the most severe discipline inculcated by the man? It was held by all indeed to be wonderful, but not imitable. Malachy showed that it was imitable by the mere act of sitting and keeping silence. In a few days he had imitators not a few, stirred by his example. So he who at first sat alone ${ }^{6}$ and the only son of his father, became now one of many, from being the only-begotten ${ }^{7}$ became the firstborn among many brethren. ${ }^{8}$ And as he was before them in

1 Lam. iii. 27, 28 (inexact quotation).

2 Heb. v. S.

3 The rule of silence was very strictly observed by the Cistercians. This explains the stress laid by St. Bernard, here and elsewhere, on Malachy's practice. Cp. the l'reface of Ihilip of Clairvaux to l. P. vi. : "In truth I have learned nothing th't can more effectively deserve the riches of the grace of the Lord than to sit and be silent, and always to condescend to men of low estale."
4 Isa. $\mathrm{xxxii}$. 17 (vg.).
- Lam. iii. $2 S$.
7 John i. 14, 18.
5 I's. cxix. I4l (vg.).
8 Rom. viii. 29. 
conversion, ${ }^{1}$ so was he more sublime than they in conversation; and he who came before all, in the judgement of all was eminent above all in virtue. And he seemed both to his bishop ${ }^{2}$ and to his teacher, ${ }^{3}$ worthy to be promoted to the degree of deacon. And they constrained him.4

6. (4) From this time onwards the Levite ${ }^{5}$ of the Lord publicly girded himself to every work of piety, but more especially to those things in which there seemed some indignity. In fact it was his greatest care to attend to the burial of the dead poor, ${ }^{6}$ because that savoured not

1 The technical word for entry into a religious order.

2 Cellach, archbishop of Armagh (\$ I 9 ), son of A edh, and grandsoll of Maelisa, who was abbot of Armagh 106.-1091. Ile was born early in toSo. Of his chillhood and youth we know nothing, for the statement of Meredith Hanmer (Chron. of Ireland (1633), p. IOI) that he is said to have been "brought up at Oxford" is probably as inaceurate as other assertions which he makes alout him. Cellach was elected abbot of Armagl in August, 1105 , and in the following month (September 23 ) he received Holy Orders. In 1106 , while engaged on a visitation of Munster, he was consecrated bishop. This he departed from the precedent set by his eight predecessors, who were withont orders (\$ 19). He was one of the leaders of the Komanizing party in Ireland, and attended the Synod of kalhl reasail in II Io (Kealing, iii. 307). Ile died in his fiftieth year, at Arrpatrick, in co. Limerick, on April I, II29, and was burierl on April 4 at Lismore. These facts are mainly gathered from the Annals. For more about Cellach, see p. xxxir.

${ }^{3}$ Imar. See above p. II, n. I.

4 Luke xxiv. 29. - Malachy can harily have been more, he was protably less, than twenty-three years of age at this line. See 1. 16, n. 2 .

5 I. e. deacon.

${ }^{6}$ It does not appear that deacons as such were specially concemed with the burial of the cleat. The present passage, indeed, implies the contraıy. Nalachy was made deacon against his will ; his care for the dead poor is mentioned as a work of piety, voluntarily superadded to the duties of his office. His sister (see below) would have been unlikely to ask him to abandon a practice which he could not decline. Iut there was ancient precedent for a deacon engaging in such work, of which Malachy may have been aware. At Alexandria throughout the persecution of Valerian, one of the deacons, Eusebins by name, not wilhout danger to himself, prepared for burial the bulies of "the perfect and blessed martyrs" (Eus., II. L. vii. I1. 24). 
less of humility than of humanity. Nor did temptation fail to test our modern 'Tobit, ${ }^{1}$ and, as in the old story, it came from a woman, ${ }^{2}$ or rather from the serpent through a woman. ${ }^{3}$ His sister, ${ }^{4}$ abhorring the indignity (as it seemed to her) of his office, said : "What are you doing, madman? Let the dead bury their dead." ${ }_{5}$ And she attacked him daily with this reproach. ${ }^{\text {" But he }}$ answered the foolish woman according to her folly," "Wretched woman, you preserve the sound of the pure word, ${ }^{8}$ but you are ignorant of its force." So he maintained with devotion, and exercised unweariedly the ministry which he had undertaken under compulsion. For that reason aiso they ${ }^{9}$ cleemed that the office of the I 19 (?) priesthood should be conferred upon him. And this was done. But when he was ordained priest he was about twenty-five years old. ${ }^{10}$ And if in both his ordinations the rule of the Canons seems to have been somewhat disregarded--as indeed loes secm to have been the case, for he received the Levitical ministry before his twenty-fifth, and the dignity of the priesthood before his thirtieth year "-it may well be

1 Tobiac. The Greek of the liwok of Tobit, followed hy the Englisl, versions, enlls the father Tolit, and the son Tobias; the Vulgate calls both Tobias. The text of chap. ii. is longer in the Vulgate than in the Greek an I Jinglish, and neither of the verses (Vulg. 12, 23) from which St. liernard here borrows words is represented in the latter.
2 Tohit ii. I2 (vg.).
4 She is mentioned agrin in $\$ I x$.
3 Cp. Gen. iii, 12 f.
"Tolit ii. 23 (vgr).
8 I's. xii. 6.
5 Matt. viii. 22.
7 P'rov. xxvi. 5 .
9 Cellach and Imar.

10 Malachy completed his twenty-fifth year in 1 rzo. Sec p. I 30 , n. 2. For the date of his ordination to the priesthood see $\Gamma$. I6, n. 2 .

11 for the canons of councils which regu'a ed the minimum age of deacon- and priests reference may be male to the article "Orilers, Ioly," by the late Dr. Ed" in Iatch in the Dictionary of Christian Antiguities, vol. ii. p. I 4 is $\mathrm{f}$. Fiom a very carly date they were respectively twenty-five aud thirty years, in accordance with the statement of the text, though there were some exceptions in 
ascribed to the zeal of the ordainer and the merits of him who was ordained. ${ }^{1}$ But for my part, I consider that such irregularity should neither be condemned in the case of a saint, nor deliberately claimed by him who is not a saint. Not content with this the bishop

I I 20 also committed to him his own authority ${ }^{2}$ to sow the holy seed ${ }^{3}$ in a nation which was not holy, ${ }^{4}$ and to give to a people rude and living without law, ${ }^{5}$ the law of life and of discipline. He received the command with all alacrity, even as he was fervent in spirit, ${ }^{6}$ not hoarding

remote places. The eighth-century Irish Canons, known as the Hiberninsis, prescribe the same minimum ages for the diaconate and presbyterate, and add a clause, the gist of which seems to be that a bi-hop at the time of lis consecration must be thirty or forly years of age (Wasserschlt ben, hische Kanonesammluns, i $\$ S 5$, p. 8). As liate as the year Io\$9, at the Council of Mclfi, presided over by Pope Urlan Il., it was decreed (ean. 5, Manci, xx 723) thal nome should be admitted deacon under twenly-four or twenty-fice years of age, or pilest uniter thirty. But at the Council of Ravenna, I 315 (can. 2, ibid. xxv. 537), the ages were lowered to twenty and twenty-five respectively.

1 Cellach " ould hardly have understood the neel for this apology. It is more than prolable that he was ignorant of tlie canons referred to. Ile himself was ordaines, apparently to the priesthond, in I 05 , when he was under twenty-six, and conseerated bishop in I I06, when he was under twenty-seven years of age. St. Bernard himself seems to have been ordained priest when he was about twenty-five years old (Vacandard, i. 67).

2 In other words he made him his vicar. This may well have been in II 20 ; for the Annals record that in that year Cellach made a visitation of Munster. It was quite natural that during a prolonged absence from his see he should leave its administration in the hands of one who had proved himself so capable as Malachy. And we shall sce that this date harmonizes with oblier chironological data. If, then, we place the beginning of Malachy's vicariate in s 120 , his ordination as priest, which appears to have been not much earlier, may be dated in I I I9, when he was " abont twenty-five yenrs of age," $i, c$. probably soon after his twenty-fourth birthday. II is admission to the diaconate may be placed at least a year earlicr, $i . t$. in IIIS. Indeerl, if we could be sure that in Ireland the normal interval between admision to the diaconate and to the priesthood was at all as long as in other countries we might put it further back.

3 Luke viii. 5 .

4 I Pet. ii. 9.

6 Rom. xii. II. 
up his talents, but eager for profit from them. ${ }^{1}$ And behold he began to root out with the hoe of the tongue, to destroy, to scatter. 2 day by day making the crooked straight and the rough places plain. ${ }^{3}$ He rejoiced as a giant to run everywhere. ${ }^{4}$ You might eall him a consuming fire burning the briers of erimes." Vou might call him an axe or a mattock casting down " evil plantings. ${ }^{7}$ He extirpated barbaric rites, he planted those of the Chureh. All out-worn superstitions (for not a few of them were discovered) he abolished, and, wheresoever he found it, every sort of malign influence sent by eqil angels. ${ }^{8}$

7. In fine whatsoever came to his notice which was irregular or unbecoming or perverse his eye did not spare $;^{9}$ but as the hail seatters the untimely figs from the figtrees, ${ }^{10}$ and as the reind the dnst from the face of the th, ${ }^{11}$ so did he strive with all his might to drive out efore his face and destroy entirely such things from his people. And in place of all these the most excollent legislator clelivered the heavenly laws. He made sgulations full of righteousness, full of moderation and in grir. Moreover in all churches he ordained th "...ustur" sanctions and the decrees of the holy fathers, and espe vially I the customs of the holy Roman Chureh. ${ }^{12}$ Hence it is that to this day there is chanting and psalmody in them at the

1 Cp. Mall. xxv. $24 \mathrm{ff}$.

3 Isa. xl. 4 .

6 l's. Ixxiv. 6 (vg.).

B l's. Ixxviii 49 (vg. : inexact quotation).

- lizek. v. I , etc.

11 l's. i. 4 (vg).

12 Malachy acted in accordance with the aims of Gillert, bishop? of Iimerick, who alout the year I IOS, wrote these words ( Di Usu Ecclesiastico, in Usther, 500): "I have endeavnucd to rescribe the canonical custom in saying the hours and performing the office of the whole ecclesiastical order... to the end that the various and schismatical orkers, with which almost the whole of Ircland has been deluded, may give place to the one Catholic and koman office." 
canonical hours after the fashion of the whole world. For there was no such thing before, not even in the city. ${ }^{1}$ He, however, had learnt singing in his youth, and soon he introduced song into his monastery, ${ }^{2}$ while as yet none in the city, nor in the whole bishopric, could or would sing. Then Malachy instituted anew ${ }^{3}$ the most wholesome usage of Confession, ${ }^{4}$ the Sacrament of Confirmation, the Marriage contract-- of all of which they were either ignorant or negligent. ${ }^{5}$ And let these serve as an example of the rest, for [here] and through the whole course of the history we omit much for the sake of brevity.

$S(5)$. Since he had a desire and a very great zeal for the honouring of the divine offices and the veneration of the sacraments, lest by chance be might ordain or teach anything concerning these matters otherwise than that which was in accordance with the rite of the universal Church, it came into his mind to visit Bishop Malchus,"

1 Armagh.

2 This was probally the monastery of SS. Peter and Part. See

1, 11. 5. J. de Backer's suggestion (AA.S.S., Nov. ii. I, p. 147), lik... " monastery" was liangor is negatived by the whole ermtext, which re?ers only to Ammagh.

3 The word "anew" (de nouo) seems to indicate St. Bernard's belief that it was only in eomparalively recent times that the usages to which he refers had fallen into desnetude.

4 It is interesting to olscrve that Confession is here nut ranked as a sacrament.

5 For the statcments in this section sce Additional Note A.

'Mael Isa Ua hAinmire, who is always called Malchus in Latin documents, though a native of Ireland, had been a monk of Winchester, as we are hese told. He was elected first bishop of the Danish colony of Waterford in 1096, and was consecrated by Anselm, assisted by the bistops of Chiehester and Rochester, at Canterbury on December $2 S$, having previously marle his profession of oberlienee to the archlishop as one of his suffragans (Eadmer, P. 76 f.: Ussher, P P. 518, 565). Ile signed the Acts of the Symod of Rathlyeasail in I I Io as arehbishop of Cashel (Keating. iii. 307 ! Ihe had probalsy been translated to that see shortly after its foundalion in 1106 (see below, 1. 65, n. 4). The Synod of Rathlreasail enlarged the Danith diecese of Waterford by adding to it an 
that he might give him fuller information on all puints. He was an old man, full of day's ${ }^{1}$ and virtues, and the wisdom of God was in him." $\mathrm{He}$ was of Irish nationality, but had lived in England in the habit and rule of a monk in the monastery of Winchester, from which he was promoted to be bishop in Lismore, ${ }^{3}$ a city of Munster, and one of the noblest of the cities of that kingdom. There so great grace was bestowed upon him from above that he was illustrious, not only for life and doctrine, but also for signs. Of these I set down two as examples, that it may be known to all what sort of preceptor Malachy had in the knowledge of holy things. He healed a boy, who was troubled with a mental disorder, one of those who are called lunatics, in the act of confirming him with the holy unction. This was so well known and certain that he soon made him porter of his house, and the boy lived in good health in that office till he reached manhood. He restored hearing to one who was deaf; in which miracle the deaf person acknowledged a wonderful fact, that when the saint put

extensive non-1)anish area, which ireluded the ancient reli ious site of Li,more, on which St. (arlluach or Mochuta had founded a communily in the early part of the seventh century (Lanigan, ii. 353). The Synod decreed that the see of this diocese should be either at Lismore or at Waterford, apparenty siving preference to the former (see p. xlvii). It would seem that afer organizing the diocese of Cashel Malchus retired to his former "parish," just as at a later date Malachy retired from Armagh to I own (\$31), placing his see at Limore. There, at any rate, he was established when Malachy vi ited him, and there he cied in I 35 "after the SSth year of his pilgrimage" (A.F.MI.). An attempt has been made to rlistinguish Mael Isa Ua hAinnire from the Malchus of the text (Lanigan, iv. 74),

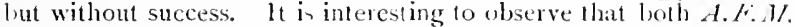
and $A$. T. style him bishop of Waterford in the record of his deall.

1 Gen. xxxy. 29; 1 Chron. xxiii. 1 : Jol, xlii. 16.-Mlalchus was in his $75^{\text {th }}$ year when Malachy visited him in 1121 . Sce preceding note, and p. 20, n. 3 .

2 I kings iii. $2 S$.

3 An error for Waterford. 11 is explained $1 . y$, and confinms, the suggestion that Malchus transferred the see to Iismore. 
!! 米 his fingers into his ears on either side he perceived that two things like little pigs came out of them. For these and other such deeds, his fame increased and he won a great name; so that Scots ${ }^{1}$ and Irish flowed together to him and he was reverenced by all as the one father of all.

When therefore Malachy, having received the blessing of lather Imar, and having been sent by the bishop, ${ }^{2}$ came to him, after a prosperous journey, he was 1121 kindly received by the old man; and he remained with him for some years, ${ }^{3}$ in order that by staying so long he might draw fuller draughts from his aged breast, knowing that which is written, With the ancient is zeisdom. ${ }^{4}$ But I suppose that another cause of his long sojourn was that the great Foreseer of all things would have His servant Nalachy become known to all in a place to which so many resorted, since he was to be useful to all. For he could not but be dear to those who knew him. In fact one thing happened in that period, by which in some

1 Throughout the Lifi, Siotia is used, in its later sense, for the country now called Scotland; and here the Scots are evidently its inhalitants. But traces of earlier usage remain in $\$ 1+$, "a Scotic (i. $\iota^{\prime}$. Irish) work," $\$ 6 \mathbf{1}$ " We are Scots," and 72 where Ireland is called "further Scotland" (ulterior-Siotia).

2 Ceilach. Note lma's share in the matter, and cp. p. I1, n. I.

3 Malachy must have been the archbishop's vicar for a consideralle time if the account of his labours in that calpacity $(\$ 7)$ is not grusly exargrerated. Ilence, if his vicariate legran in I I I 9 or I I 20 his departure for lismore can hardly have been earlier than II 2 ; and as he spent "some years" there before he was raised to the episcopate (II24; see \$ I6), it cannot have been later. S:mmel O'llanky, bishop of Dublin, died on July 4, I I 21 , and Cellach at once male an attempt, which proved unsuccessful, to take possession of the vacant see. Samul's successor, Grestory, was duly elected, and was consecrated at Iambeth on Octoher 2. (O.C.C. P. 31 ; A.U. I12I; John of Worcester, ed. J. HI. R. Weaver, IgoS, p. I6; Usther, 532 ). It may have been in Angust or September, on the retum of Cellach from Dublin, that Malachy was released from his office and went to Lismore.

4 Job xii. 12. 
measure made manifest to men what had been known

to God as being in him.

9. A conflict having taken place between the king of South Munster ${ }^{1}$ - which is the southern part of Ireland-

1127 and his brother, ${ }^{2}$ and the brother being victorious, the king, driven from his kingdom, sought refuge with Bishop Malchus. ${ }^{3}$ It was not, however, it order that with his help he should recover the kingdom; but rather the devout prince gave place unto zerath ${ }^{4}$ and made

1 I read $r e x$ australis Mumoniae, for $r x$ l/mmoniac in the printed text, restoring the wold australis from two of de Backer's MSS. The king is said in $\$$ I $S$ to have been Cormac, $i . e$. Cormac Mac Carthy, son of Teague Mac Carthy, who succeeded his father as king of Desmond (South Munster) in I I24. Ile was never king of the whole of Nunster. That he went to lismore in 1 i $2 \mathrm{I}$ is very probable. For the Amnals tell us that in that year Turlough O'Cunor, king of Connaught, invaded Desmond, and "arrived at the temon of Lismore" (A.I. say that he destroyed lismore, which can hardly be true). What more likely than that one of the sons of Teague, the rejoning monarch of Desmond, should fly before that fomidable warrior to the sanctuary of Mochuta? But St. Bernard errs in supposing that he was then ling of Desmond. On Cormac, see also p. 43, n. 5 .

2 Donough Mrac Carthy. See next note. There is a brief notice of him in Tundale, p. 42 .

3 That the narrative of this and the following section is historical, but that St. Bernard has misplaced it, is proved by the following ex. tract from A.T. under the year i 27 : "A hosting by Toideltach, king of Ireland [really of Connaught], till he reached Corcach, he himself on tand and his fleet at sea going round to Corcach, ravagring Mfunster by sea and by land so that he drove Cormac mac meic Carthaig into l.ismore in pilgrimage. And Toirdellach divided Mumster into two parts, the southern half [Desmond] to Donnchad mac meic Carthaig; and the northern half [Thomond] to Conchobar o Briain. .. Cormac mac meic Carthaig came from his pilgrimage, and made an alliance with Conchobar o Briain and with all the men of Mluma, save those of Tuathmuma. Donnchad mac meic Carthaig came from them-for he was not in the alliance-with 2000 men."

The other Annals have notices to the same effect. These evints occurred in 1127 , three years after Malachy retumed from his long stay at Lismore, and was made bishop of Connor (\$ I6). If he had the part which is ascribed to him in the restoration of Cormac, he must therefore have paid two visits to Lismore, which St. Bernand has confounded. That he was in the south of Ireland for a con. siclerable time prior to 1 I 29 will appear later (p. 40, n. 2 ).

$\$$ Lom. xii. 19. 
a virtue of necessity, ${ }^{1}$ choosing to lead a private life. And when the bishop was preparing to receive the king with due honour, he declined it, saying that he preferred to be as one of those poor brothers who consorted with him, to lay aside his royal state, and to be content with the common poverty, rather to await the will of God than to get back his kingdom by force; and that he would not for his earthly honour shed man's blood, ${ }^{2}$ since it would cry unto cod against him from the ground. ${ }^{3}$ When he heard this the bishop rejoiced greatly, and with admiration for his devotion satisfied his desire. Why more? The king is given a poor house for his dwelling, Malachy for his teacher, bread with salt and water for his food. Moreover for dainties, the presence of Malachy, his life and doctrine, were sulficient for the king; so that he might say to him, Howe szeet are thy zerords unto my tuste, yea, sweeter than honey to my mouth. ${ }^{4}$ liesides, er'ry night he weatered his couch with his tears," and also with a daily bath of cold water he quenched the burning lust for evil in his flesh. And the ling prayed in the words of another king, Look uton my affiction and my fain; and forgize all my sins. ${ }^{6}$ And God did not turn areay his frajer nor this mercy from him. ${ }^{7}$ And his suppliation atas heard, ${ }^{8}$ although otherwise than he had desired. For he was troubled about his soul; but God, the avenger of innocence, willing to show men that there is " remuinder for the mon of foace, ${ }^{9}$ was preparing mean

1 Necessitatem in uirtute'n conucrtit. Apparenlly a ploverbial expresion. Cp. (Juintilian Declam. iv. Io: "Faciamus potius de fine remedium, de necessitate solatim"; Jer. Adr. Rufin. iii. 2 : "Ilabeo gratian quod facis de necessitate uirtutem"; Es. 54.6 (1lilherg): "Arripe, quaeso, occasionem el fac de necessitate uirt utem." Chaucer's "To maken vertu of necessitee "is well known (Kinghtes Tale, 3042, Squicres Tale, 593, Troilus and Criscyde, iv. $\left.{ }_{15} S 6\right)$.
2 Gen. ix. 6.
5 Ps. vi. 6 (vg.).
8 Eccius, li, I $\boldsymbol{I}$,
3 Gen.iv, ro.
'I's, xxiv, IS.
4 P. cxix. $\mathrm{IO}_{3}$.
7 I's. Ixvi. 20 .
9 P's. $\mathrm{xxx}$ ii. 37 (vg.). 
while to evecute a judgement for the oppressed, ${ }^{1}$ which wis utterly beyond his hope. And God stirred up the spirit of a neighbouring king : ${ }^{2}$ for Ireland is not one kingdom, but is divided into many. This king therefore seeing what had been done, was filled with wrath ; and indignant, on the one hand, at the freedom of the raiders and the insolence of the proud, and on the other, pitying the desolation of the kingdom and the downfall of the king, he went down to the cull of the poor man; urged him to return, but did not succeed in persuading him. He was instant, nevertheless, pledged himself to help him, assured him that he need not doubt the result, promised that God would be with him, whom all his adtersaries zould not lie alle to resist. ${ }^{3}$ He laid before him also the oppression of the poor and the devastation of his country ; yet he prevailed not.

ro. But when to these arguments were added the command of the bishop ${ }^{4}$ and the advice of Malachythe two men on whom he wholly depended--at length, with difficulty, he consented. A king followed a king, and according to the word of the king, as a'tas the will in heaven, ${ }^{6}$ the marauders were driven out with absolute ease, and the man was led back to his own, with great rejoicing of his people, and was restored to his kingdom. From that time the king loved and always reverenced Malacliy; so much the more because he had learned more fully in the holy man the things that were worthy of reverence and affection. For he could not be ignorant of the

1 l's. cxlvi. 7.

22 Chron. xxxvi. 22.-Conor O'brien. See p. 21 , n. 3. It appears from the last sentence of the passage there quoted that I) onough MacCarthy, to whom Turlough OConor had given the kingdom of Desmond, had driven out O'brien fiom Thomond. 'Ti. is explains the anxiety of the latter to make alliance with Cormac. Il is action was less disinterested llian St. Bernart repesents it.
3 Luke xxi. I5.
5 Judas Maccabous.
* Malchus.
c I Mlace. iii. 6o, 


\section{THE LIFE OF ST. MALACHY}

holiness of him with whom he had enjoyed so much intimacy in his adversity. Therefore he honoured him the more in his prosperity with constant acts of friendship, and faithful services, and he heard him stadly, and when he heard him did many things. ${ }^{1}$ But enough of this. * Nevertheless I suppose it was not without purpose that the Lord so magnified him then before lings, ${ }^{2}$ but be was a chosen ressel unto Him, about to bear His name before kings and princes. ${ }^{3}$
1 Mark vi. 20.
2 T's. cxix. $4^{6 .}$
3 Acts ix. I 5 . 


\section{CHAPTER II}

Malachy's pity for his diciased sister. He' restores the . Wonastiry of Bangor. His first Miracles.

I I (6). Mranivhlee Malachy's sister, whom we mentioned before, ${ }^{1}$ died : and we must not pass over the visions which he saw about her. For the saint indeed abhorred her carnal life, and with such intensity that he vowed he would never see her alive in the flesh. But now that her flesh was destroyed his vow was also destroyed, and he began to see in spirit her whom in the body he would not see. One night he heard in a dream the voice of one saying to him that his sister was standing outside in the court, and that for thirty entire days she had tasted nothing; and when he awoke he soon understood the sort of food for want of which she was pining away. And when he had diligently considered the number of days which he had heard, he discovered that it went back to the time when he had ceased to offer the living bread from hea'en ${ }^{2}$ for her. Then, since he hated not the soul of his sister but her sin, he began again the good practice which he had abandoned. And not in vain. Not long after she was seen by him to have come to the threshold of the church, but to be not yet able to enter; she appeared also in dak raiment. And when

1 See §6. Malachy's sister is here sail to have died while he was at Lismore; but whether during his earlier or later visit to that place cannot be determined.

2 John vi. 5 I. 
he persevered, taking care that on no single day she shruld be disappointed of the accustomed gift, he saw her a second time in whitish raiment, admitted indeed within the church, but not allowed to approach the altar. At last she was scen, a third time, gathered in the company of the white-robed, and in bright clothing. ${ }^{1}$ You see, reader, how much the effectual fercent frayer of a righteous man araileth. ${ }^{2}$ Truly the kingrdom of heaven sufferth wiolence and the violint take it by force. ${ }^{3}$ Does not the prayer of Malachy seem to you to have played the part as it were of a houscbreaker to the heavenly gates, when a sinful woman obtained by the weapons of a brother what was denied to her own merits? 'Ihis riolence, good Jesus, Thou who sufferest dost exercise, strong and merciful to sare, ${ }^{4}$ shoring mercy and strength zerith thine arm, and preserving it in thy sacrament for the saints which are in the earth, ${ }^{6}$ unto the end of the world. ${ }^{7}$ Truly this sacrament is strong to consume sins, ${ }^{8}$ to clefeat opposing powers, to bring into heaven those who are returning from the earth.

12 (7). The Lord, incleed, was so preparing His beloved Malachy in the district of Lismore for the glory of I is name. But those who had sent him, ${ }^{9}$ tolerating his absence no longer, recalled him by letters. When he was restored to his people, ${ }^{10}$ now better instructed in all that was necessary, behold a zork prefared and kept by God 11 for Malachy. A rich and powerful man, who held the place of Bangor and its possessions, by inspiration of God immediately placed in his hand all that he had and

1 Aets x. 30 .

3 Matt. xi. I2.

5 lake i. 51 .

7 Malt. xxviii. 20.

y) Cellach and Imar (\$ \&).

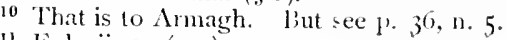

11 liph. ii. 10 (vg.).

2 Jas. v. 16 .

4 C. Isa. Ixiii. I.

6 I's. xvi. 3 .

8 Ps. vii. 9 (vg.). 
himself as well. ${ }^{1}$ And he was his mother's brother. ${ }^{2}$ But kinship of spirit was of more value to Malachy than kinship of the flesh. The actual place also of Bangor, from which he received his name, ${ }^{3}$ the prince ${ }^{4}$ made over to him, that there he might build, or rather rebuild, a monastery. For indeed there had been formerly

1 This perso' was apparently the coarb of Com rall, the foumler of Bangor. It would seem that he had been but a short time in office, for Oengus O'Gormin, coarb of Comgall, died at Lismore in $1123(A . U$.$) , probably during Malachy's sojourn there. It is \mathrm{n} n$ impossible that the unnamed coarb, mentioned in the text, was Murtongh Ollanratty, who died at Armagh in 113 I (A.F.M.). The statement that he gave "himself" to Malachy seems to mean that he placel himself under his rule in the new community.

2 If the identification suggested in the preceding note is correct, Malachy's mother belongeil to the family of O'llanratty, which in the eleventh and twelfth centuries held the chicfaincy of Ui Méith Machi or Ui Méith Tíre, now the barony of Monarghan, in the county of the same name.

${ }^{3}$ Cognominabatur. This verb oceurs seventeen times in the Vul. gate, and almost always indicates a new or altemative name. In the present passage it certainly applies, not to Malachy's baptismal name, but to its Latin equivalent, Nalachias, which he probably assumed when he became abbot of langor, or bishop of Down. The remark that he received it from Bangor is to he explained thus. A legend, which has a place in Jocelin's Life of St. Patrick (\$ 9.5$)$ and is therefore at least as old as the twelfth century, relates that I'atrick, viewing the valley in which the monastery of Comgall was afterwarils consirncterl, perceived that it was "fillect with a multitwile of the heavenly hos'." From this story, no loubt, came the name "Valley of Angels (Vallis Angeloram)," by which it was known in the early seventeenth century, and prohably long hefore (Reeves, p. I99). If this name, or the legend on which it was lased, was known to Malachy it is quite conceivalble that on aceount of his connexion with Bangor, he adopted, as the Latin alternative of Máel Náetíc, a name which is only th: Hebrew for my anse? with a Latin ternination. That St. Bermard was aware of the significance of the name, and liked to dwell upon it, is clear from Sermon ii. $\$ 5$. It may he adde 1 that the legend just mentioned is connected with a folk-etymology of the worl liangor (Binnithor) which explain d it as "white choir." For the true elymology see Kuno Veyer, "Zur Weltischen Wortkunde," 66 (Prenss. Akral. Sit:., 1913$)$.

A Princets. This worl does not necessarily imply that the donor of langen was a secular chieftain. St. Bernarl is somewhat arbitrary in his use of such titles: and frinceps occurs very frequently in A.U. up to the tenth cen'ury as an expuivalent of abbot. 
a very celebrated one under the first father, Comgall, ${ }^{1}$ which produced many thousands of monks, and was the head of many monasteries. A truly holy place it was and prolific of saints, bringing forth most abundant fruit to Golt, ${ }^{2}$ so that one of the sons of that holy community, Lugaid ${ }^{3}$ by name, is said to have been the founderhimself alone-of a hundred monasteries. I mention this in order that the reader may infer from this one instance what an immense number of others there were. In fine, to such an extent did its shoots fill Ireland and

1 Comgall, who was a lict of Dál Araide (Adamnan, i. 49), was born at Nagheramorne, near Larne, co. Antrim (Reeves, p. 269), hetween 516 and 520 . He founded the monastery of Bangor when he was about forty years old, prohably in 559 , and presidert over it till his death in $602(A . U$.). According to his Latin Life $\langle \$ 13$, I'lummer, ii. 7), so great a number of monks came to him there that there was not rom for them: "he therefore founded very many cells and many monasteries, not only in the district of Ulai,l, but throughout the other province of Ireland." "Tlere were as many as 3000 monks under lis rule. (On the last leaf of an ancient service book of the monastery, known as the Antiphonary of Bangor (Facsimile edition by F. E. Warren, 1 S93, vol. ii. p. 33), there is a lymm which gives a complete list of the abbols-fifteen in number-from Comgall to Cronan $(+691)$, in whose periorl of office it was written. The site of St. Comgall's monastery is heside the Rectory of the parish of liangor, co. Down, about lalf-a-mile from Bangor Bay, near the entrance to Belfast Lough.

2 Rom. vii. 4.

3 Luanus. This is probally Lugaid, or Molua, the founder of Lismore in Scotland, who died in 592 (A.U.) and is commenorated on June 25 (Oengus, Gorman). lle was a I'ict and of the same trilite as S. Comgall, both heing descended from Fiacha Araide (L.R. I5 c, e); and in later times was the patron saint of the diocese of Argyll (Adamnan, p. 371 ). IJe may be the Bishop Lugidus who ordained St. Comgall, and afterwarls restrained him from leaving lreland (Plummer, i. p. lix. ; ii. $\mid p .6,7$ ). But there is no evidence, apart from the statement of St. Bernard, that either this bihop or Lugaid of Limmore was a member of the community at Bangor. There is a Life of Lugaid of Limmore in the Itreviary of Alerdeen (Prop. Sanct. pro temp. aest. ff. $5 v-7$; summarized in Forbes, Kalendars of Scottish Saints, p. 410). Ilis principal foundation after Lismore was kosenarkic in Ross. Mr. A. B. Scott ('lictish Nation, 1918, p. 347 f.) mentions also Mortlach (Lanffshire) and Clova (Aberdeenshire); and Bishop Forbes (l.c.) adds other sites with which his name is connected. 
Scotland ${ }^{1}$ that those verses of David seem to have sung beforehand especially of these times, Thou visitist the earth and blessest it; thou makest it a'ry flenteous. The river of God is full of acater: thou preparest their corn, for so thou providest for the carth, blessing its rizers, multiplying its shoots. With its drops of rain shall it rejoice while it orminates ${ }^{2}$ and in like manner the verses that follow. Nor was it only into the regions just mentioned, but also into foreign lands that those swarms of saints poured forth as though a flood had risen ${ }^{3}$ of whom one, St. Columbanus, came up to our Gallican parts, and built the monastery of Luxovium, and was made there a sreat people. ${ }^{4}$ So great a people was it, they

${ }^{1}$ St. Comgall himself is said to hwe been minded in his ealtier days to go on pilgrimage to "Britain," and to trave been dissuaderl

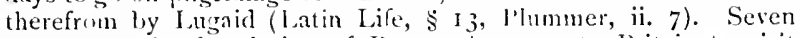
years after the fountation of Rangor he went to Britain to visit "certain saints" (ibid.\$22, p. I I). It was prolably on this occasion that he spent some time on the istand of llinba (Eilean-nanaomh?) in the company of SS. Columba, Canice and others (Alamnan, iii. 17). It was somewhat later, apparently, that St. Columba went with some companions on a mission to Brode, king of the lists (ibit. ii. 35); and we need not question the statement that Comgall and Canice were among those who went with him, though there is reason to doubt that Congall was the leader of the hand, as hi; Life implies (\$ $5 \mathrm{I}, \mathrm{p}$. I $\$$ ), and though the Life of St. Canice, which frequently refers to his visit, or visits, to Scotlant (\$ 17, 19-2I, 23, P'lummer, i. 15S), never mentions the incident. It is probable, therefore, that the founder of Bangor took part in the evangelization of Scotland ; but the memory of very few monasteries founderl by him in that country, besides the community in the island of Tiree (Lifi, $\$ 22$, p. II ; see Scott, op. cit. p. 239), has been preserved to later ages. NIr. Sicott credits members of the comnumity of lbangor with the foundation of Paisley, Kingarth and Applecross (ibid. p. $337 \mathrm{ff}$.). See also previous note.

2 Ps. lxv. 9, Io (vg., ine sact quntation). ${ }_{3}^{3}$ Lulke vi. 48.

4 Gen. xii. 2.-St. Culumbanns was the greatest of the lrish missionaries on the Continent of Europe. Born in Leinster, accorling to Bruno Krusch (Ionae V'itae Sanctorum, p. 22) in $53^{\circ}$, or as others loold in 543, he entered the community of liangor not long after its foundatim, and after spencling "many cycles of years" there, he sailed for France about 590. IIis principal monasteries were Luxeuil (Luxovium) in the department of I Iatte Saine, and Bobbio in Lombarly. At the latter place he died, November 23, 6r5. 
say, that the choirs succeeding one another in turn, the solemnities of the divine offices went on continuously, so that not a moment day or night was empty of praises. ${ }^{1}$

I 3. (8) Enough has been said about the ancient glory of the monastery of liangor. This, long ago destroyed by pirates, ${ }^{2}$ Malachy eagerly cherished on account of its remarkable and long-standing prestige, as though he were about to replant a paradisc, ${ }^{3}$ and because many bodies of the saints slept there. ${ }^{4}$ For, not to speak of those which aere buried in piace, ${ }^{5}$ it is said that nine hundred persons were slain together in one day by pirates. ${ }^{6}$ Vast, indeed, were the possessions of that place; i but Malachy, content with the holy place alone,

Ilis Life was written by Jonas, alont 6.40. It was critically editcr by Krusch in M.G.H. (Seript. rerum Merovingic., vol. iv. I-I 52) and sulsecpuently as a separate volume (Ionac l'itae Sanctorum Columbani, ledastis, Tohannis, 1905). The story of hiv labours has been told ly G. T. Stokes in his Celtic Church in Ireland, Lect. vii., and by many other modern writess. See also the collection of documents in l'alrick Fleming's Collectanca (Lovanii, 1667). Luxcuil is abuut eighty miles from Clairvaux, and less than seventy from St. Bernard's carly home at Dijon. Fifty years after the death of St. Columbanus it adopter the ule of St. Benedict. It was a wcll-known estalilishment in St. Bernard's day, though hy that time its glory had declined. It was suppressed in i7S9 (M. Stokes, Three Months in the Forests of France, p. 67).

1 The Acremetac, founded abont the middle of the fifth century, were the first to practise the laus pirennis, from which they derived their name (Dict. of Christian Antiquities, s.v.). It was adopted in the early years of the following century at the ronastery of St. Maurice in the Valois, from which it spread 10 many other religious establishments (AA.SS., Nov., i. 54 Sff.).

${ }^{2}$ A.U. 823 (reate $\$ 2.4$ ): "The plundering of Bangor in the Ards by Foreigners [i.e. Norsemen], and the spoiling of is oratory; and the relics of Comgall were shaken out of their shrine." A.I. add, "and its learned men and bishops were slain with the sword."
3 Gin. ii. S.
- Ecclus, xliv. 14.

6 This obviously exaggerated statement may refer to the event mentioned in note 2 , or to a later occasion (95\$), when "Tanaidhe, son of Odhar, coarb of Pangor, was killed by foreigners" (A.U.).

7 "Even al the IDissolution [1539] it was found to be possessed of the temporalities and spiritualities of thirty-four townlands, 
resigned all the possessions and lands to another. For indeed from the time when the monastery was destroyed there was always some one to hold it with its possessions. For they were both appointed by election and were even called abbots, preserving in name but not in fact what had once been. ${ }^{1}$ And though many urged him not to alienate the possessions, but to retain the whole together for himself, this lover of poverty did not consent, but caused one to be elected, according to custom, to hold them; the place, as we have said, being retained for Malachy and his followers. And perhaps, as afterwards appeared, ${ }^{2}$ he would have been wiser to have kept it all; only he looked more to humility than to peace.

I4. So, then, by the command of Father Imar, taking with him about ten brethren, he came to the

together with the tithes of nine rectories or chapels" (Reeves, p. 94). The lands included the entire parish of Bangor, together with part of the adjoining parish of IJulywood, and eight outlying townlands (Archdall, ed. Mloran, i. 235).

1 'This remark is interesting as showing that the title "abbot of Bangor" was in use in the twelfth century. The last person to whom it is given in the A.U. is Indrechtach, who died in gof. From that time onwards "coarb of Comgall" (or in one instance, "coarb of Bangor") is substituted for it. St. Bernard is supported by the Annals when he asserts that so-called abbots were elected down to Malachy's time. A.U. preserve the names of twenty abbots or coarls between $\$ 24$ and I 123 . But St. Bemard leaves the impression that the religious community of Bangor ceased to exist on its destruction by the Norse pirates, and that subsequently the "abbots" merely held the lands that liat belonged to it, and exercised no spinitual discipline. There are good reasons, howeser, for the contrary opinion. Thus Abbot Mloengal, who dicel in 871 , was a "pilgrim." Ablot Moenach (died 921) was "the head of the learning of the island of Ireland." Ceile, coarl, of Comgall, went on pilgrimage to Rome in $92 S$, and died there in 929: he was' a scribe and anchoret, apostolic doctor of all Irehand, and (if C.S. can be trusted) a bishop. I)ulhinnsi, bishop of Bangor, died in 953. Finally, Diarmait Ua Maelietchia, coarb of Congall, whom C..S. calls a bishop, died in 1016 . It wits probably not till after that date, as Recves (p. I 5.1) asswres us, that the monastery legan to decine.

2 See $\$$ 6I, 62. 
place and began to build. And there, one day, when lye himself was cutting with an axe, by chance one of the workmen, while he was brandishing the axe in the air, carelessly got into the place at which the blow was aimed, and it fell on his spine with as much force as Malachy could strike. He fell, and all ran to him supposing that he had received a death-wound or was dead. And indeed his tunic was rent from the top to the boitom, ${ }^{1}$ but the man himself was found unhurt, the skin so very slightly grazed that scarcely a trace appeared on the surface. 'The man whom the axe lad laid low, stood unharmed while the bystanders beheld him with amazement. Hence they became more eager, and were found readier for the work. * And this was the beginning L of the miracles ${ }^{2}$ of Malachy. Moreover the oratory was finished in a few days, made of smoothed planks indeed, but close!y and strongly fastened together-a Scotic work, ${ }^{3}$ not devoid of beauty. ${ }^{4}$ And thenceforward God

1 Matt. xxvii. 5 I.

2 John ii. II.

3 "Scotic" is obvionsly to be understood here in its earlier meaning as equivalent to "Irish." From this depatture from his ordinary usage (see p. 20 , note I) we may infer that St. Bernard is quoting the words of his authority. 'The habit of constracting chumches of wood prevailed in early times among the Celtic and Saxon tribes in the liritish Isles, the introduction of stone building for such purpose; lxing due to Roman influence (1'lummer, Bede, ii. I01). The older custom lingered longer in Ireland than elsewhere; and by the time of Bede it had come to be regarded as characteristically $I_{1}$ ish, thongh wooden churches must still have been numerous in England (Berle, H.E., iii. 25). In a document of much later date, the Life of the Irish Saint Monenna (quoted in Adamnan, p. $177 \mathrm{f}$.), we read of " a church constilucted of smovthed planks according to the custom of the Scottish races"; and the writer adds that "the Scots are not in the habit of building walls, or causing them to be built." P'etrie (Pp. I38-151) maintained that stone churches were not umusual in early Ireland; but he admits (pp. 34I-344) that one type of church-the oratory (in Irish dairtheach, i. $e$. house of oak - - was very rarely constucted of scine. The only two passages which he cites (p. 345) as mentioning stone oratories (he says he might have produced others) are not to his purpose. The first is a notice in $A . U .788$, of a man being killed ai the door of a "stone oratory": but another, and apparently 
was served in it as in the ancient days; that is, with similar devotion, though not with like numbers. Malachy presided over that place for some time, ${ }^{1}$ by the ordinance of Father Imar, ${ }^{2}$ being ${ }^{*}$ at once the ruler and the rule of the brethren. ${ }^{-}$They read in his life how they should behave themselves, and he was their leader in righteousness and holiness before God $;^{3}$ save that besides the things appointed for the whole community he did many things of an exceptional kind, in which he still more was the leader of all, and none of the others was able to follow him to such difficult practices.

1 * At that time and place a certain man was sick, and the devil stood by him and suggested in plain speech that he should never heed the admonitions of Malachy, but if he should enter his house, he should attack and kill him with a knife. And when this became known, those who ministered to him, the sick man himself informing them, brought word to Malachy and warned him. But he, seizing his accustomed weapons of

better, reading sulstitutes lapide for lapidei, thus altering the entry lo a slatement that the man was killed "by a stone at the door of the oratory." The second is Colgran's rendering ('Trias, p. 162) of a sentence in 7 rip. iii. $74,1 \% 232$, in which there is in reality $n 0$ mention of any ecelesiastical edifice. So far as I am aware, there is no indisputable reference in Irish literature to a stone oratory carlier than the one mentioned below, \$6I.

${ }^{4} \mathrm{Cp}$. the quatrain of Rummun on an orat ory which was in course of construction at Rathen (Otia Merseiana, ii. 79):

"O my Lord! what shall I do

About these great materials?

When will these ten hundred planks

lie a structure of compact beanty?"

1 Evidently until he became bishop. The next sentence implies that the time spent al langor was of considerable lengll, as does also the remark at the end of $\$ 15$. Si. Bernard, howcver, seems to have been mistaken in supposing that Malachy resignet the abbacy on his consecration. See P. 36 , note $5 ;$ p. 40 , nole 1 ; p. So, note 1 ; p. ro4, note 3 ; 1. II 2 , nole 5 ; p. II 3 , note I.

${ }^{2}$ CP. P. II, note 1.

3 Luke i. 75. 
* prayer, boldly attacked his enemy, and put to flight both disease and demon. But the man's name zeas !! - *** Malchus. ${ }^{1}$ He is brother according to the flesh of our Christian, abbot of Mellifont. ${ }^{2}$ For both are still alive, now brothers yet more, in spirit. ${ }^{3}$ For when he was delivered, immediately he was not ungrateful, but in the same p'ace, having turned ${ }^{4}$ to the Lord, ${ }^{5}$ he changed both his habit and his mind. And the brethren knew that the evil one was envious of their prosperity; and they were edified and made more careful henceforth.

i 5 (9). At the same place he healed a cleric, named Michael, who was suffering from dysentery and despaired of, by sending him something from his table. A second time, when the same person was smitten with a very grave disorder, he cured him both in body and mind. And from that moment he clave to God ${ }^{6}$ and to Malachy His servant, fearing lest a worse thing should come unto him ${ }^{7}$ if once more he should be found ungrateful for so great a benefit and miracle. And at present, as we have heard, he presides over a monastery in the parts of Scotland; and this was the latest of all Malachy's foundations. ${ }^{8}$ Through such deeds of Malachy both his reputation and his community increased daily, and his name became great both within and without the monastery, though not greater than the fact. For

1 John xviii. 10.

2 For Christian and Mellifont Abbey, see $\$ 39$. This Malchus is mentioned again in $\$ 52$.

3 This is not a mere conventional phrase. In a passionate outburst of grief St. Bernard says of his brother Gerard, who had recently died, "IIe was my brother by blood, yet more my brother in religion" (Cant. xxvi. 4).

${ }_{4}$ Conversus. C. P. I4, note I. The meaning is that after his recovery Malchus entered the community of liangor.

5 Acts ix. 35.

${ }^{6} 2$ Kings xviii. 6.

7 John v. 14.

8 The abbey founded by Malachy at Soulseat. See $\S 6 S$. 
indeed he dwelt ${ }^{1}$ there even after he was made bishop, for the place was near the city. ${ }^{2}$

1 Demorabatur, literally, lingered, or tarricd. The fact seems to be that Bangor was Malachy's headquarters for the rest of his life, except the ten years wlich intervened between his expulsion from it (\$ I $)$, and his resignation of the see of Armagh (\$ 3I). See p. 33 , note $\mathbf{I}$. St. Bernard was apparently puzzled by the fact that Malachy continued to live at Bangor after lis consecration, instead of going to the see-city ; and he makes a not very satisfactory apology for it.

2 The city is evidently Connor; but it is not near bangor. The two places are twenty-five miles apart, and lielfast Lough lies between them. In Malachy's day they were in different tribal territories. 


\section{CHAPTER III}

St. Muluchy becomes Bishop of Comnor; he builds the Monastery of Iveragh.

I6 (10). AT that time an episcopal see was vaeant, ${ }^{1}$ and had long been vacant, beeause Malachy would not assent : for they had elected him to it." But they persisted, and at length he yielded when their entreaties were enforced by the command of his teacher, ${ }^{3}$ together with that of the metropolitan. ${ }^{4}$ It was when he was just entering the thirtieth year of his age ${ }^{5}$ that he was eonsecrated bishop

1 Connor: see below. It is clear that after Malachy's consecration it was the see of a diocese which included Bangor (\$ 15 ) and Down, the present Downpatrick ( $\$ 3 \mathrm{I}$ ). The inference is lighly probable that it included the whole district which cunstituted the "parish [i.e. diocese] of Conncr," according to the decree of the synod of Kathbreasail in I I Io (Keating, iii. 303 : see above p. xli), that is to say, roughly, the present united dioceses of Down, Connor and Dromore. It would seem that Malachy was its first bishop.

2 Here, again, St. Bernard implies that a long period elapsed between Malacly's return from Lismore and his consecration; for the reason given in $\$ 12$ for lis recall is inconsistent with the supposition that he had already been elected to a bisloopric which Cellach and Imar wished him to accept. They desired to have him with them at Armagh. He must have been "elected" either while he was at Armagh or after he went to Bangor.

3 Imar.

+ Cellach. See $\S 19$, where Cellach and his predecessors are called metropolitans.

${ }_{5}$ Tricesimo ferme aetatis suae anno. A.F.M. record under the year I12.4 that "Nael Maedoc Ua Morgair sat in the bishopric of Comor." "This agrees with the date of his consecration as given here. See p. I2S, note I. He was consecrated bishop by Cellach (§ I 19 ).

We have seen (p. 20, note 3 ) that Malachy probably went to Lismore late in I I $2 \mathrm{r}$. He spent several years there, and, according to St. Bernard, another long period at Armagh and Bangor before his consecration in II 24. This must be pronounced impossible. The most probahle solution of the chronological difficulty is that 
and brought to Connor; for that was the name of the city.

1124 But when he began to administer his office, the man of God understood that he had been sent not to men but to beasts. Never before had he known the like, in whatever depth of barbarism; never had he found men so shameless in regard of morals, so dead in regard of rites, so impious in regard of faith, so barbarous in regard of laws, so stubborn in regard of discipline, so unclean in regard of life. They were Christians in name, in fact pagans. ${ }^{1}$ There was no giving of *tithes or firstfruits; no entry into lawful marriages, no making of confessions: nowhere could be found any who would either seek penance or impose it. Ministers of the altar were exceeding few. But indeed what need was there of more when even the few were almost in idleness and ease among the laity? There was no fruit which they could bring forth from their offices among a people so vile. For in the churches there was not heard the voice either of preacher or singer. ${ }^{2}$ What was the athlete of the Lord ${ }^{3}$ to do? He must either yield with shame or with danger fight. But he who recognized that he was a slepherd and not a

through ignorance of Irish ecclesiastical affairs St. Bernarl misunderstood the information supplied to him, and thus scparated Malachy's tenure of the abbacy of Bangor from his episcopate, though the two were in reality conterminous. For the significance of Malachy's recall to the North, see Introduction, p. liii. f. ; and for a fuller discussion, R.I.A., xxxv. 250-254.

${ }^{1}$ Cp. Giraldus, Top. iii. I9: "It is wonderful that this nation should remain to this day so ignorant of the rudiments of Christianity. For it is a most filthy race, a race sunk in vice, a race more ignorant than all other nations of the rudiments of the faith."

${ }^{2}$ For the statements in the preceding sentences, see $A$ dditional Note A.

${ }^{3}$ St. Aug., De Cir. Dei, xiv. 9. 2. Cp. Ignatius, Pol. 2 ; Hero I. It may be noted that most of the MSS. of the Latin version of the lgnatian Epistles are Burgundian, and that among them is a Clairvaux MS. of the $\mathrm{s} 2$ th century. Lightfoot, $I_{\xi} n$. and Pol., i. 1 I 9. 
hireling, elected to stand rather than to flee, prepared to give his life for the sheep if need be. ${ }^{1}$ And although all were wolves and there were no sheep, the intrepid shepherd stood in the midst of the wolves, rich in all means by which he might make sheep out of wolves ${ }^{2}$ *admonishing in public, arguing in secret, weeping with one and another; accosting men now roughly, now gently, according as he saw it to be expedient for each. And in cases where these expedients failed he offered for them a broken and a contrite heart. ${ }^{3}$ How often did he spend entire nights in vigil, holding out his hands in prayer! And when they would not come to the church ine went to meet the unvilling ones in the streets and in the broad angs, and going round about the city, he eagerly sought ${ }^{4}$ whom he might gain for Christ.

i 7 ( I I). But further afield also, none the less, he very frequently traversed country parts and towns with that holy band of disciples, who never left his side. He went and bestowed even on the unthankful their portion of the heavenly meat. ${ }^{6}$ Nor did he ride on a horse, but went afoot, in this also proving himself an apostolic * ? man. Good Jesus, how' great things thy warrior suffered for Thy name's sake? from crime-stained children. ${ }^{8}$ How great things he endured for Thee from those very men to whom, and on whose behalf, he spoke good

1 John x. I I -13 .

2 Compare St. Bernard's words to Pope Eugenius III. alyout his Koman subjects ( $D \dot{e}$ Cons., iv. 6) : "I know where thou dwellest, unlelievers and subverters are with thee. They are wolves, not shecp: of such, however, thou art shepherd. Consideration is good, if by it thou nayest perhaps discover means, if it can be done, to convert them, lest they subvert thee. Why do we doubt that they can be turned again into sheep, who were once sheep and could be turned into wolves?'

$\because$ P's. li. I7.

4 Cant. iii. 2 ; cp. Ps. lix. 6, I 4 ; Luke xiv. 2 I.

5 Luke vi. 35

7 Acts ix. I6.

6 Lulie xii. 42.

8 Isa. i. 4 (vg.). 
things. Who can worthily express with how great vexations he was harassed, with what insults he was assailed, with what unrighteous acts provoked, ${ }^{1}$ how often he was faint with hunger, how often afflicted reill cold and nakedness? ${ }^{2}$ Yet with them that hated peace he reas at peacemaker, ${ }^{3}$ instunt, nevertheless, in season, out of scason ${ }^{4}$ Being defamed he intreated ${ }^{5}$ when he was dealt with unrighteously he defended hinself with the shield of patience and overcame evil zeith sood. ${ }^{6}$ Why should he not overcome? He continued knocking, ${ }^{7}$ and according to the promise, at length, sometimes, to him that knocked it was opened. ${ }^{8}$ How could that not follow which the Truth ${ }^{9}$ had declared beforehand should follow? The right hand of the Lord brought mighty things to pass, ${ }^{10}$ because the mouth of the Lord spoke ${ }^{11}$ the truth. Hardness vanished, barbarity ceased; the relullious house ${ }^{12}$ began gradually to be appeased, gradually to admit reproof, to receize discipline. ${ }^{13 *}$ Barbarous laws disappear, Roman laws are introduced; everywhere the ecclesiastical customs are received, their opposites are rejected; churches ${ }^{14}$ are rebuilt, a clergy is appointed in them; the solemnities of the sacraments are duly celebrated; confessions are made; congregations ${ }^{15}$ come to the church; the celebration of marriage graces those who live together. ${ }^{16}$ In fine, all things are so changed for the better that to-day the word which the Lord speaks by the prophet is applicable to that nation; those wio before were not my people are nozer my people. ${ }^{17}$

1 Cp. 2 I'et. ii. 7 f.

3 Ps. cxx. 6, 7 (vg.).

5 I Cor. iv. 13.

7 Acts xii. 16.

9 John xiv. 6.

11 Isa. i. 20.

13 Lev. xxvi. 23 (vg.).

15 Plebes.

17 I Pet. ii. Io, combined with Ilos. ii. 24.
22 Cor. xi. 27.

+2 Tim. iv. 2.

6 kom. xii. 2 I.

8 Matt. vii. 8 ; Luke xi. Io.

10 Ps. cxviii. I 5, I6.

12 Ezek. ii. 5, etc.

14 Basilica:

16 See Additional Note $A$. 
I 8 (1 2). It happened after some years that the city ${ }^{1}$ was destroyed by the king of the northern part of Ireland; * for out of the north all evil breaks forth. ${ }^{3}$ And perhaps that evil was good for those who used it well. *For who knows that God did not wish to destroy by such a scourge the ancient evils of His people? By a necessity so dire Malachy was compelled, and he retired with a crowd of his disciples. Nor was his retirement spent in idleness. It gave opportunity for building the monastery of Iveragh, ${ }^{4}$ Malachy going there with his

1 The city was Bangor, though St. Bernard may have taken it to be Connor. The word city (civitas), which he no doubt found in his authority, might be applied, like its Irish equivalent, cathair, to either place: but to St. Bernard it would naturally suggest an episcopal see. Connor was within the suzerainty of the king of the northern part of Ireland, Bangor was outside it. See next note.

2 Conor O'Loughlin, who is called king of the north of Ireland in the Annal; (s.a. I 136). He succeeded his father Donnell as king of Ailech (Grenan Ely, co. Donegal, the residence of the kings of the nurthern Ui Neill) in $112 \mathrm{I}$, and the next year he in. vaded the northern part of Ulaid, the district in which Bangor is situated. He invaded Magh Colsha (Iveagh, co. Down) and Bregha (Meath), with the help of the Dal Araide (the district round Connor, co. Antrim) in II2S. He finally subdued Ulaid in II30, and "plundered the country as far as the east of Ard [i.c. the l)aronies of the Ards, in which lies Bangor], both lay and ecclesiastical property." He was murdered on May 25 , i 36 (A.U., A.L.C.). It has been supposed that the expedition of 1130 was the occasion of the destruction of Bangor mentioned in the text. But St. Bernard places it, and the consequent departure of Malachy to the south, before the death of Cellach in 1129 (\$ I9), and we have found reason to believe that Malachy was at Lismore in I 27 (p. 21, n. 3). Though no raid by Conor in that year is referred to in the Annal;, that firct cannot be regarded as proof that none took place.

3 Jer. i. 14.

4 Ibracense. That this monastery was in Iveragh, a barony in the county of Kerry, north of the estuary of the Kenmare River, and in Cormac Mac Carthy's kingdom of Desmond, was apparently first suggested by Lanigan (iv. 92). The identification is almost certainly correct. It is more difficult to determine the part of the barony in which the monastery was sitnated. O'IIanlon suggested Church Island, near Cahirciveen, where there are some ecclesiastical remains, traditionally known half a century ago as "the monastery" (K,I.A. xv. Io7). But these appear to be of much 
brothers, in number one hundred and twenty. ${ }^{1}$ There King Cormac met him. He it was who at a former time driven out of his kingdom, under the care of Malachy by the mercy of God received consolation $;^{2}$ and that place was in his kingdom. The king rejoiced to see Malachy, placing at the disposal of him and those who were with him himself and all that he had-as one who was neither ungrateful nor unmindful of a benefit. Many beasts were immediately brought for the use of the brothers, much gold and silver was also supplied, with regal munificence, for the expense of the buildings. He himself also zeas coming in and going out zeith them, ${ }^{3}$ busy and ready to serve in attire a king, but in mind a disciple of Malachy. And the Lord blessed that place for Malachy's sake, ${ }^{4}$ and in a short time he was made great in goods, possessions and persons. And there, as it were beginning anew, the burden of law and discipline which he laid on others he bore with greater zeal himself, their bishop and teacher. Himself, in the order of his course, ${ }^{5}$ did duty as cook, himself served the brothers while they sat at meat. ${ }^{6}$ Among the brothers who succeeded one another

earlier date than the twelfth century. More plausible is the conjecture of the Rev. Denis O'Donoghue, that the site is on another Church Island, in Lougl Curane, near Waterville. On it are the ruins of a church which, in the opinion of Mr. P. J. Lynch, was built in the twelfth century (J.K.S.A.I. xxx. I 59 f.). Malachy seems to have spent some time at Lismore before going to Iveragh.

1 This sentence seems to imply that Malachy brought with him the liangor community, or the greater part of it, and made a new home for it in Iveragh. If so the inference is obvious that up to I 27 Malachy resided at Bangor, and was still abbot.

2 See $\$ \$ 9$, 10 .

3 Acts ix. 28 (inexact quotation).

4 Gen. xxx. 27.

5 Luke i. 8.

${ }^{6}$ Cp. Luke xii. 37 ; xxii. 27. 
in singing or reading in church he did not suffer himself to be passed over, but strenuously fulfilled the office in his place as one of them. He not only shared but took the lead in [the life] of holy poverty, being especially zealous for it more abundantly than they all. ${ }^{1}$

1 Cp. I Cor. xv, Io; 2 Cor, xi. 23. 


\section{CHAPTER IV}

Being made Archbishop of Armagh, he suffers many troubles. Peace being malle, from being Archbishop of Armagh he becomes Bishop of Down.

I9 (I 2). Meanwhile ${ }^{1}$ it happened that Archbishop Cellach 2 fell sick: he it was who ordained

I 129 Malachy deacon, presbyter and bishop: and knowing that he was dying he made a sort of testament ${ }^{3}$ to the effect that Malachy ought to succeed him, ${ }^{4}$ because none seemed worthier to be bishop of the first see. This he gave in charge to those who were present, this he commanded to the absent, this to the two kings of Munster "

1 That is, while Malachy was in Iveragh.

2 Cellach is here mentioned by name for the first time. See p. I4, n. 2 .

3 Iarris (Ware's Works, ii., "Writers," p. 69) identifies this testament with the Testamentum ad ecclesias, a traet attributed to Cellach, which is apparenlly no longer extant. But it may be doubted whether the testament mentioned in the text was committed to writing.

4 The designation by a coatb of his successor seems to have been unusual. But in II24 Malachy had in this way been appointed abbot of Bangor ( $\$ \mathrm{I} 2)$; and in I1 34 Murtough designated Niall as his successor in the abbaey of Armagh (\$22).

5 Conor O'Brien, ling of Thomond, and Cormac Mac Carthy, king of Desmond. See $\$ 9$, and P. 2I, notes I-3. Murtough O'Brien, king of Nunster, fell into ill-health in I I I4, and his brother Dermot attempted, evidently with some success, to seize the throne. Dermot died in I I $S$ and Murtough early in the following year. Turlough $\mathrm{O}^{\prime}$ Conor, the powerful king of Connaught, promptly invaded Munster, and aivided it into two vassal kingdoms, Thomond and Desmond. The former he gave to the sons of lermot, of whom Conor was one, the latter to Teague Mac Carthy. Apparently Conor O'brien soon established himself as sole ling of Thomond, and Cormac Mac Carthy became king of Desmond on the death of his father, Teagne, in II 24. We have seen that both of them were deposed in 1127 , and quickly restored ( $\$ 9$ f. : see p. 21, n. 3; p. 23 , n. 2). From that time Conor and Cormac were allies. Cormac 
and to the magnates of the land he specially enjoined by the authority of St. Patrick. ${ }^{1}$ For from reverence and honour for him, as the apostle of that nation, who had converted the whole country to the faith, that see where he presided in life and rests in death ${ }^{2}$ has been held in so great veneration by all from the beginning, that not merely bishops and priests, and those who are of the clergy, but also all kings and princes are subject

married Conol's niece ( $A . T$. I I $3 S$ ). Together in 1533 they invaded Connaught $(A . F . M$.$) , and the next year they made another suc-$ cessful expedition through Connaught into Ulster (then ruled by Conor O'Loughlin: see p. 4O, n. 2), in the course of which they burned the church of Ralhluraigh, now Maghera, co. Derry, near the border of the diocese of Armagh (D.A.I.). This expedition must be referred to hereafter (p. 5I, n. 2). But Conor evidently aspired to be arthi of Ireland, and he found it clesirable to remove a possible rival. Accordingly Cormac was murdered by his fatherin-law, Conor's brother, in 1138 , and Conor became king of all Munster. He was now the most powerful prince in Ireland; but he died, after a lingering illness (Tunclale, p. 42), in I I 42, without attaining his ambition.

It is clear from the present passage that Conor O'Brien followed in the footsteps of his predecessors in the same family as a supporter of the new movement in the Irish Church. Cormac, as we know, was the friend and disciple of Malachy : his devotion to the Church is witnessed to by the beatiful edifice built by him at Cashel, still known as "Conmac's Chapel," which was consecrated in II34; and by his title of "Bishop-ling," which has been the subject of so much discussion. See Petrie, pp. 2S3-307; and for the crozier found in Cormac's supposed tomb, G. Coffey, Gaide to the Celtic Antiquities of the Christian Period in the National Muscum, Dublin, p. 64. But it must be added that the contemporary Vision of Tundale, which apparently cmanated from Cormac's kingdom of Desmond, while bearing emphatic testimony to his generosity to "Christ's poor and pilgrims," charges him with heinous crimes strangely inconsistent with St. Bernard's sketch of his character (Tundale, P. 44 f.).

1 It seems that the successor (coarb) of the founder of a church was supposed to speak with his authority. $C_{P}$. the Epistle of Cummian in Ussher, p. 442.

${ }^{2} \mathrm{Cp}$. $\S 65$. It is generally believed that St. Patrick was buried at Downpatrick (see Recves, p. $223 \mathrm{ff}$.) ; but Olden contended (not convincingly) that the statement marle here by St. Bernard is correct (R.I.A. xviii. 655 ff.), while Bury (Life of St. Patrick, p. 211 ) has "little hesitation in deciding that the obscure grave was at Saul." 
to the metropolitan ${ }^{1}$ in all obedience, and he himself alone presides over all. But a very evil custom had developed, by the devilish ambition of certain powerful persons, that the holy see ${ }^{2}$ should be held by hereditary succession. For they suffered none to be bishops but those who were of their own tribe and family. And for no short time had the execrable succession lasted, for fifteen generations (as I may call them) ${ }^{3}$ had already passed in this wickedness. And to such a point had an eail and adulterous ${ }^{4}$ generation ${ }^{5}$ established for itself this distorted right, rather this unrighteousness worthy of punishment by any sort of death, that although at times elerics failed of that blood, yet bishops never. In a word there had been already eight before Cellach, married men, and without orders, albeit men of letters. ${ }^{6}$ Hence, throughout the whole of Ireland, all that subversion of ecclesiastical discipline, that weakening of censure, that abandonment of religion of which we have

1 This word cannot have been in St. Bernatd's document, for it is unknown in early Irish ecclesiastical terminology, and in Irish hierarchical arrangenents it would have no meaning. The context proves that the persons to whom it is here applicd are the abbots of Aimagh, of whom Cellach was one. It probably represents a Latin rendering of "coarl (successor) of l'atrick," a title commonly given to the abbots of this period. The document portrayed the coarbs as rulers of the church of Armagh. St. Bernard would naturally infer that they were bishops. When he found that their authority extended beyond Armagh he would no less maturally style them archbishops or metropolitans. $C_{p}$. Serm. $i, \S 6$, where the story of $\$ \S 19-31$ is briefly summarized.

2 Armagh.

3 Quasi generatienibus quindecim. The "quasi-generations" are apparently the periods of office of successive coarbs. St. Bernatd seems to have written "fifteen" in mistake for "twelve." Sec Additional Note 13, p. I65.

${ }^{4}$ Aclulterous, because it took possession of the church, which shou'd ha e b en married to true hishops. Cp. \$20, "the adultery of the church," Malachy "leeing jomed to another spouse;" \$2t, Malachy's "former spouse," and the vision of Cellach's wife.

"Natl. xii. 39 ; xvi. 4 .

"On the statements in these sentences, see Adlitional Note b. 
spoken already; hence everywhere that substitution of raging barbarism for Christian meekness-yea, a sort of paganism brought in under the name of Christianity. For - a thing unheard of from the very beginning of the Christian faith-bishops were transferred and multiplied, without order or reason, at the will of the metropolitan, tho that one bishopric was not content with one bishop, but nearly every single church had its bishop. ${ }^{1}$ No wonder; for how could the members of so diseased a head be sound?

20. Cellach, greatly grieving for these and other like evils of his people-for he was a good and devout man - took all care to have Malachy as his successor, because he believed that by him this evilly rooted succession might be torn up, ${ }^{2}$ since he was dear to all, and one whom all were zealous to imitate, and the Lord zeas with him. ${ }^{3}$ Nor was he deceived of his hope; for when he died Malachy was put into occupation in his room. But not soon nor easily. For behold there is one of the evil seed to seize the place-Murtough by name. For five years, relying on the secular power, ${ }^{5}$ this man

1 That bishops were numerous in Ireland at this period is indubitable. Fifty attended the Synod of Fiallh meie Oengusa (A.U. IIII), and probably all of them came from the provinces of Ulster and Munster (above, p xxxviii). But this eannot have been due to the irregularities at Armagh of which St. Bernard complains. There were many lishops in Ireland in its earliest Christian period. See Reeves, 123-136; Todd, 27 ff.

2 Malachy was not of the Clann Sinaich, to whieh at this period the coarbs of Patrick belonged. See p. 6, n. 5, and Additional Note B, p. I65.

" I Sam. iii. 19, etc.

1 Cellach died on $\Lambda$ pril I, I I29, and was buried at Lismore on April 4. On April 5, the day after his funeral, Murtough was appointed coarb (A.C.).

5 Ile was probally supported by Conor O'Longhlin, who was king of Oriel, the district in whieh Arnagh was situated (A.F.M. II36). On him see P. 40, n. 2. The "five years" are the periol from Nurtongh's election to his death, September 17, II 34 $(. t . I . M$.$) -nearly five years and a half.$ 
fastened himself upon the church, not a bishop but a tyrant. For the wishes of the devout had rather supported the claim of Malachy. At last they urged him to undertake the burden according to the ordinance of Cellach. But he, who shunned every high office as nothing else than his downfall, ${ }^{1}$ thought that he had found good ground of excuse, because at that time it was impossible that he should have a peaceful entry. All were enger for so holy a work and pressed him; especially the two bishops, Malchus ${ }^{2}$ and Gilbert, ${ }^{3}$ of whom

1 Geoffrey, St. Bernard's secretary, recalls a saying of his about "one of the saints," which actualiy appears in the first antiphon at Mattins in the office of St. Malachy, and which Geoffrey applies to St. Bernard himself: "Blessed is he who loved the law, but did not desire the chair [of dignity]." ( $V$.P. iii. $S)$.

2 On Malchns see p. IS, n. 6 . He wa's now about eighty-five years of age.

3 Gillebertus (as St. Iernard writes the name) is a latinized form of the Irish Gilla espuig (servant of the bishop), which is anglicized Gillespie. With that Irish name he subseribed the Acts of the Synod of Rathbreasail (Keating, jii. 306) ; and we may therefore affirm with confidence that he was an Irishman. Gilbert was a friend of the famous thinker and ecelesiastical statesman, Anselm, who was archbishop of Canterbury from 1093 to I I09. The two men met each other for the first time at Rouen, probably in $1_{0} \$_{7}$, when Anselm was called thither to the leathbed of William the Conqueror. 'Twenty years later, Gilbert, then bishop of Limerick, wrote a letter of congratulation to Anselm on his victory over Ifenry I. in the controversy concerning iuvestiture (August I 107). In his reply Anselm intimates that the long interval had not blurred his recollection of their former companionship, from which we may infer that Gibert's personality had male a considerable impression upon him. Anselm also states that he had learned (probably from the superscription of his friend's letter) that he was now a bishop. It would seem, therefore, that Gilhert had been consecrated recently, and not, like the contemporary bishops of Danish sees in Ireland, by the English Primate (see the letters in Ussher, 5II, 512). IIe probably became bishop of Limerick about i 105. Shortly after his correspondence with Anselm, and perhaps by his influence, he was appointed papal legate for Ireland, the first, as St. Bernard tells us, who had held that office. He was legate when in I IoS or i Iog he wrote his tract De Statu Ecclesice (see above, p. xxx. ff.); and in II Io, as legate, he presiled over the Synod of Rathbreasail. In I 39 or I 40 , being old and infirm, he resigned his legatine commission and his see ( $\$ 38$ and 1 . 73 , note 1 ). He died in I I45. Gilbert was 
the former was the elder ${ }^{1}$ of Lismore mentioned above, the second he who is said to have been the first to exercise the office of legate of the Apostolic See throughout the whole of Ireland. These, when three years had now passed in this presumption of Murtough and dissimulation of Malachy, ${ }^{2}$ tolerating no longer the adultery of the church and the dishonour of Christ,

$13^{2}$ called together the bishops and princes of the land, ${ }^{3}$ and came, in one spirit, to Malachy, prepared to use force. * But he refused at first; pleading the difficulty of the project, the numbers, strength and ambition of that noble stock, urging that it was a great venture for him, a poor man and of no account, to oppose himself to men so many, so great, of such sort, so deeply rooted, who now for well-nigh two hundred years had held as by hereditary right the sanctuary of God, ${ }^{4}$ and now also had taken possession of it before him; that they could not be rooted out, not even at the cost of human life; that it was not to his advantage that man's blood should be shed ${ }^{5}$ on his account; and lastly, that he was joined to another spouse " whom it aras not laveful for him to put az'ay. ${ }^{\top}$

2 I (I4). But when they persisted eagerly in the con!rary opinion, and cried out that the arord had come

evidently a strong man, who had much influence on the affairs of the Irish Church. It is therefore surprising that the only reference to him in the native Annals is the notice of his death in the Chronicon Scotorum.

1 Senior. This is alnost a lechnical word for the head of a religious community. Malchus is called ard senvir Gaoidheal (high senior of the Irish) in A.F.M. I 135 .

"Ilis dissimmlation was his disregard of the divine call in the vision described in $\$ 2 \mathrm{I}$.

${ }^{3}$ Cp. A.F.M. II32: "Mael Maedoc Ua Morgair sat in the coarbate of Patrick by the request of the clerics of Ireland."

4 Ps. Ixxxiii. I 2 (vg.). - See Additional Note B, p. I65.

5 Geñ. ix. 6.

6 The diocese of Connor.

7 Matt. xix. 2 ; Mark x. 2. 
forth from the Lord, ${ }^{1}$ and moreover ordered him with all authority to undertake the burden, and threatened him with an anathema, he said, "You are leading me to death, but I obey in the hope of martyrdom ; yet on this condition, that if, as you expect, the enterprise has good success, and God frees his heritage from those that are destroying it, ${ }^{2}$ all being then at length completed, and the church ${ }^{3}$ at peace, it may be lawful for me to return to my former spouse and friend, poverty, ${ }^{4}$ from which I am carried off, and to put in my place there another, if then one is found fit for it." Note, reader, the courage of the man and the purity of his purpose who, for Christ's name, neither sought honour nor dreaded death. What could be purer or what braver than this purpose, that after exposing himself to peril and labour he should yield to another the fruit-peace and security itself in the place of authority? And this he does, retaining for himself according to agreement a free retum to porerty when peace and freedom are restored to the church. When they gave the pledge, at length he assented to their will ; or rather to the will of God, who, he remembered, had long foreshown to him this occurrence, at the fulfiment of which he was now grieved. For indeed when Cellach was already ailing there appeared to Malachy-far away and ignorant [of Cellach's condition] $\mathrm{a}$ woman of great stature and reverend mien. When he inquired who she was, the answer was given that she was the wife of Cellach. ${ }^{5}$ And she gave him a pastoral staff which she held in her hand, and then

1 Ezek. xxxiii. 30.

3 The church of Armagh.

2 Jer. I. II.

4 The "spouse" is primarily the diocese of Connor. His voluntary poverty is especially associated with his episcopate there in Sermi i. $\$ 6$.

5 It can hardly be doubted that this means the diocese of Armagh (c). p. 45, n. 4). Buth § I9 and the title "son of purity" ( $A . U$. I 29$)$ imply that Cellach was not married. 
disappeared. A few days later, Cellach, when he was dying, sent his staff to Malachy, indicating that he should succeed him : and when he saw it he recognized that it was the same which he had seen [in vision]. It was the remembrance of this vision which specially put Malachy in fear, lest if he still refused he might seem to resist the Divine will, which he had ignored long enough. ${ }^{1}$ But he did not enter the city as long as that intruder lived, lest by such act it should happen that any one of those should die to whom he came rather to minister life. Thus for two years (for so long the other survived), living outside the town, he strenuously performed the episcopal office throughout the whole province. $^{2}$

22 ( 15 ). When that person, then, had been removed by sudden death, ${ }^{3}$ again one Niall [Nigellus] (in II34, if truth nigerrimus, very black) ${ }^{4}$ quickly took possession of the see. And in appointing him as his successor, Murtough, while he was still alive, made provision for his life: ${ }^{5}$ he was going forth to be damned, but in the person of Niall he would go on adding to the works of damnation. ${ }^{6}$ For he also was

1 Rom. ix. 19.

2 That Malachy was in 1132 recognized by many as coarb of Patrick is confirmed by the Annals (see p. $4 S, n$. 3). But that he exercised his episcopal office "throughout the entire province" is inconsistent with the fact that in I 33 Murtough " made a visitation of Tír Eoglain [counties of Derry and Tyrone] and reecived his tribute of cows and imparted his blessing" (A.F.M. .).

${ }^{3}$ September $17,113+(A . F . M$. ). Sudden death is not suggested by the Annals.

${ }^{4}$ St. Bernard puns on the Latin name by whish he represents Niall. It is a diminutive of niger, black.

5 Josh. ix. 24 (vg.).

6 The meaning of this somewhat difficult sentence is made clear by the reference to the Gibeonites (Josh. ix). By their stralagem they "marle provision for their lives," that is, that they should continne to live instead of being exterminated with the rest of the Canaanites. In like manner Murtough provided that he should, as it were, live on and pursue his evil course, in the person of Niall. 
of the damned race, a relative of Murtough. ${ }^{1}$ But the king ${ }^{2}$ and the bishops and faithful of the land nevertheless came together that they might bring in Malachy. And lo, there was an assembly of the acicked ${ }^{3}$ to oppose them. ${ }^{4}$ A certain man of the sons of Belial, ready for mischief, mighty in iniquity, ${ }^{5}$ who knere the place where they had decided to come logether, ${ }^{6}$ gathered many with him and secretly seized a neighbouring high hill opposite to it, intending, when they were engaged with other things, suddenly to rush upon them unawares and murder the innocent. ${ }^{7}$ For they had agreed to butcher the king also with the bishop, that there might be none to aienge the righteous blood." The plan became known to Malachy, and he entered the church, which was close by, and lifted up his hands in

1 Ile was Murtough's cousin, and Cellach's brother. See the table, Additional Note B, p. I64.

2 That the king was either Conor O'Brien or Cormac Mac Carthy is highly probable. To them Cellach had confided the duty of seeing that Malachy should be his successor (\$ 19 ), and in this very year they reached the border of the diocese of Armagh (p. 43, n. 5). See p. 53, n. 5 .

3 Ps. xxii. I6.

4 The narrative of this and the next section is illustrated by the Annals under the year is 34 . A.F.M., after recording the obit of Murtough, proceed: "Niall, son of Acdh, was installed in the coarbate of l'atrick. A change of abbots in Armagh, i.e. Mael Naedoc Ua Morgair in place of Niall." In $4 . T$. we have the statement, "Mael Maedog o Mongair ascended I'atrick's chair. The Cinel Eoghain of Tulach Óg conspired against Mael Maedoc, and a flash of lightning consumed twelve men of them on the spot where they conspired against him." Thus it seems that the conspirators calme from the place now known as Tullaghoge, in the county of Tyrone, then, as now, in the diorese of Armagli. It was the district inhabited by the sept of the O'IIagans, and in it was the lia na righ, the inauguration chair of the O'Neills, kings of Ulster. The confirmation which St. Bernard's story receives from A.T. is the more important, because the two narratives are so far different that they must have come from inclependent sources.

5 Ps. lii. I (vg.).

- Cp. John xviii. 2 (vg.).

7 Ps. x. S.

8 Matt. xxiii. 35, combincd with Rev. vi. 1o ; xix. 2. 
prayer to the Lord: Lo, there came clonds and darkness, ${ }^{1}$ yea also dark zaters and thick clouds of the skies ${ }^{2}$ changed the day into nisht, ${ }^{3}$ lightnings and thunderings 4 and an horrible spirit of tempests ${ }^{5}$ presaged the last day, and all the elements thriatened speedy death. ${ }^{6} \%$.

23. But that you may know, reader, that it was the * prayer of Malachy that roused the elements, the tempest fell upon those aho sought his life, ${ }^{7}$ the dark athirland ${ }^{8}$ enveloped only those who had made ready the avorks of darkness. ${ }^{9}$ Finally, he who was the leader of so great wickedness was struck by a thunderbolt and perished with three others, companions in death as they had been partners in crime; and the next day their bodies were found half-burnt and putrid, clinging to the branches of trees, each where the wind ${ }^{10}$ had lifted him up and cast him $d o \pi m .{ }^{11}+$ Three others also were found half dead; the rest were all scattered in every direction. But, as for those who were with Malachy, though they were close to the place, the storm touched them not at all, neither troulled them. ${ }^{12}-\ln$ that fact we find fresh proof of the truth of that saying, The prayer of the righteous piereth the hearens. ${ }^{13}$ It is also a new example of the * ancient miracle, by which in former times, when all Egypt was in darkness, Israel alone remained in light, as the Scripture says, Wheresoezer Israel was there acas light. ${ }^{14}$ In this connexion occurs to me also what holy Elijah

1 I's. xcrii. 2.

3 Amos v. S (vg.).

5 Ps. xi. 6, horribilis sfiritus frocollurum: apparently a confla-

tion of the vg. with another rendering. A.V. has an horible temfest.

${ }^{6}$ Virg., fen. i. 91.

7 Ixud. iv. I9: Matt. ii. 20, etc.

9 Rom. xiii. 12.

10 Spiritus. Cp. the "spirit of tempests" in $\$ \mathbf{2 2}$ (end).

11 P's. cii. 10.

13 Ecclus. xxxv. I6 (inexact quotation).

14 Exod. x. 23 (inexact quotation).
2 Ps. xviii. I I.

4 Rev, iv. 5.

${ }^{8}$ Jol, iii. 6 (vg.). 
did, at one time bringing clouds and rain from the ends of the earth, ${ }^{1}$ at another, calling down fire from heaven on the revilers. ${ }^{*}$ And now in like manner God is glorified $i^{3}{ }^{3}$ His servant Malachy.

24 ( 16$)$. In the thirty-eighth year of his age, ${ }^{4}$ the usurper having been driven out, the poor man, Malachy, entered Armagh, pontiff and metropolitan of all Ireland. But when the king and the others who had brought him in returned home, ${ }^{5}$ he remained in the hand of God $;{ }^{5}$ and there remained for him asithout fightings, within fears. ${ }^{7}$ For, lo, the viperous brood, raging and crying out that it was disinherited, aroused itself in full strength, within and without, against the Lord and asainst Ihis Anointed. ${ }^{8}$ Moreover, Niall, seeing that flight was inevitable, ${ }^{9}$ took with him certain insignia of that see, to wit, the copy of the Gospels, which had belonged to blessed Patrick, ${ }^{10}$ and the staff covered with gold and

12 Kings xviii. 41 ff. ; Jas. v. I8.

22 Kings i. 9-1 2.

3 John xiii. $3 \mathrm{I}$.

4 This date is incorrect. The entry into the city of Armagh cannot have laken place before October 1134, when Malachy was in his fortieth (possibly thirty-ninth) year. His entry into the province (\$21) was probably made in his thirty-eighth year. This was no doubt the cause of St. Bernard's error; for one of his documents may, like A.F.M. (p. 48, n. 3 ), have used words which seemed to imply that he entered Armagh on that earlier occasion.

5 If "the king" was Cormac Mac Carthy (P. 5I, n. 2), the statement that he returned home shorlly after Malacliy obtained possession of the see, is confirmed by $A . F . M$. For they record, under I 34 , the consecration of Cormac's Chapel on the rock of Cashel.

6 Wisd. iii. 1.

8 Ps. ii. 2 ; Acts iv. 26.

9 The flight of Niall seems clearly to imply that he was in the city of Armagh. The natural inference is that "having been driven out" he was aflerwards reinstated. 'This may have happened while Malachy was absent on a visitation of Munster, mentioned in A.F.M., but apparently unknown to St. Bernatl. The statement of the latter, that Malachy "remained" in Armagh, ignores it . See further, Additional Note C, p. $168 \mathrm{f}$.

${ }_{10}$ The book of $A r m a g h$, now in the Library of Trinity College, Dublin. The manuscript was written at Armagh carly in the nimth century by a scribe named Ferdomnach ; but at an carly date it came 
adorned with most costly gems, which they call, "the staff of Jesus," because the Lord himself (as report affirms) held it in His hands and fashioned it ${ }^{1}$ which are deemed of the highest honour and sanctity in that nation. They are, in fact, very well known and celebrated among the tribes, and so revered by all, that he who is once seen to have them is held by the foolish and innaise

to be supposed that it was the work of St. Patrick himself. From this belief, perhaps, arose the name by which it was known for many centuries, and which can be traced back to the year 936-the Canon of Patrick. It is strange that it should be called here a "copy of the Gospels"; for in addition to the complete text of the New Testament it contains two lives of St. Patrick, his Confission and other historical documents. But the word Gospel was very loosely used in Ireland (see R.I.A. xxxiii. 327 f.). Misled by this description, de Backer (n. ad loc.) identifies the book mentioned by St. Bernard with the so-called "Gospels of St. Patrick," found in the shrine known as the Domnach Airgid, about I $S_{30}$, which have no connexion with Armagh or St. Patrick (R.I.A. Trans. xviii., "Antiquities," pp. I 4 ff. ; xxx. 303 ff. ; R.I.A. xxxiv. IoS ff.). For further information about the Book of Armagh the reader may consult Gwynn, especially pp. ci.-cxvi.

1 The staff of Jesus was a woolen crozier (Giraldus, Top. iii. 34), richly adorned. The story of its presentation by Christ to St. Patrick is found in the tenth-century Trif. (p. 3o), no doubt taken from an earlier source. The staff was much older than the liook of Armagh ; for we find that it was "profaned" in 789 , and it was then apparently regarded as the principal relic of St. Patrick (A.U. 788). It secms that there was a still more ancient tradition, that St. Iatrick gave it to St. Mac Cairthinn (R.I.A. xxxiv. I I4), from which it may be inferred that it once belonged to the church or Clogher. It was removed from Armagh to Dublin in IISo, and acposited in Christ Church. It was burnt in 1538 (A.L.C.). Apparently St. Bernard is the only authority for the statement that it was "fashioned" by Christ. It appears that the staff of Jesus, in the twelfth century, was regarded as a much more important relic than the book of Armash, and was more closely associated with the person and office of the coarb of Patrick. It is frequently mentioned in such a way as to suggest that it was one of the insignia of his authority (A.U. IOI 5, 1073, I101, I1 3,1157, I 66 , I $67 ; A . F . M$. I I 35, I I 39, I I43, 1 I 48,1152$)$. Similar references to the Book of Armugh do not occur till near the close of the twelfih century, immediately after the removal of the staff from Armagh (A.U. II79, I196; Gwynn, p. civ.). A very full account of the later history of the staft may be read in O.C.C. pp. viii-xx. 
people ${ }^{1}$ to be their bishop. That man-a vagabond ${ }^{2}$ and another Satan-went to and fro in the land and walked up and dozen in it, ${ }^{3}$ bearing round the holy insignia ; and, displaying them everywhere, he was for their sake everywhere received, by them winning the minds of all to himself, and withdrawing as many as he could from Malachy. These things did he.

25. But there was a certain prince, of the more powerful of the unrighteous race, ${ }^{4}$ whom the king before he left the city, had compelled to swear that he would maintilin peace with the bishop, taking from him, moreover, many hostages. Notwithstanding this, when the king left he entered the city, and took counsel with his kinsmen and friends how they might take the holy man by subtlety and kill him; but they fiared the people; ${ }^{5}$ and having conspired to slay Malachy ${ }^{6}$ they fixed a place and day, and a traitor gave them a sign. ${ }^{7}$ On that very day, when the prelate was now celebrating the solemnity of Vespers in the church with the whole of the clergy and a multitude of the people, that worthless man sent him a message in zeords of peace zeith subtlety, ${ }^{8}$ asking him that he would deign to come down to him, so that he might make peace. The bystanders answered that he should rather come to the bishop, and that the church was a more suitable place for establishing peace ; for they foresaw guile. The messengers replied that this was not safe

1 Deut. xxxii. 6.

"Gyrovagus. The word is commonly used of a monk who leaves his proper monastery, and wanders about from one cell to another (see, e.g., St. Bernard, $E_{p} .68, \S 4$ ), or to a priest who deserts his parish (Du Cange, s.v.).

3 Job i. 6,7 ; ii. 2.

4 King ( Primacy of Armagh, p. 97) thought that this was Conor O'Loughlin. But he could hardly be described as "of the unrighteous race," or as a "prince," which would indicate a petty chieftain. Probably the conspirator was a local magnate.

5 Matt. xxvi. 4, combined with Luke xxii. 2.
${ }^{6} \mathrm{Cp}$. Acts xxiii. $12 \mathrm{f}$.
7 Matt. xxvi. 4 s,
8 I Macc. i. 3 \%. 
for the prince; that he feared for his head, and that he did not trust himself to the crowds who, some days before, had nearly killed him for the bishop's sake. As they were contending in this way, these saying that he should go, those that he should not go, the bishop, desiring peace and not afraid to die, said, "Brethren, let me imitate my Master. ${ }^{1}$ I am a Christian to no purpose if I do not follow Christ. ${ }^{2}$ Perhaps by humility I shall bend the tyrant; if not, yet I shall conquer by rendering, a shepherd to a sheep, a priest to a layman, that duty which he owed to me. You also, as far as in me lies, I shall edify not a little by such an example. For what if I should chance to be killed? I refuse not to die, ${ }^{3}$ in order that from me you may have an example of life. It behoves a bishop, as the prince of bishops says, not to be lord over the clergy, but to become an example to the flock ${ }^{4}$-no other example ${ }^{5}$ truly than that which we have received from Him who humbled himself and became obedient unto death. ${ }^{6}$ Who will give me [the opportunity] to leave this [example] to $[\mathrm{my}]$ sons, sealed with my blood? Try, at any rate, whether your priest has worthily learnt from Christ not to fear death for Christ." And he arose and went his way, all weeping, and praying that he would not so greatly desire to die for Christ that he should leave desolate so great a flock of Christ.

26 ( 17 ). But as for him, setting his ashole hope in the Lord, ${ }^{7}$ he went with all speed accompanied only by three disciples who were ready to die zith him. ${ }^{8}$ When he crossed the threshold ${ }^{9}$ of the house and suddenly came

1 Cp. I Cor. xi. I.

3 Acts xxy. II.

5 Formam. The word occurs in the verse just quoted, and in the context of that which follows (Phil. ii. 7).

6 I'hil. ii. S.

8 Acts xxi. I3; John xi. I6.

9 C . Apuleius, MItanorph. xi. 23.
2 Matt. x. 38 , etc.

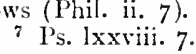

4 I l'et. v. 3 (rg., inexact quotation). 
into the midst of the armed men-himself protected by the shield of faith ${ }^{1}$ - the countenanies of them all fell, ${ }^{2}$ for dread fell upon them, ${ }^{3}$ so that the bishop could say, Mine enemies which trouble me became reak and fell." ${ }^{4}$ This zerorl is true. ${ }^{5}$ You might see the victim standing, the slaughterers surrounding him on all sides, with weapons in their hands; and there was none to sacrifice him. You might suppose their arms were benumbed ; for there was none to stretch out a hand. For even that one also, who seemed to be the head of the evil, rose up, not to assail him but to show him reverence. Where is the sign, O man, which you had given for the death of the pontiff? This is a sign rather of honour than death ; this postpones, it does not hasten death. Wonderful result! They offer peace'who had prepared slaughter. He cannot refuse it who had sought it at the risk of life. Therefore peace was made-a peace so firm that from that day the priest found his foe not merely appeased, but obedient, devoted. ${ }^{6}$ When they heard this, all the faithful rejoiced, not only because the innocent blood reas saved in that day, ${ }^{7}$ but because by the merits of Malachy the souls of many wrongdoers escaped to salvation. And fear took hold on all that were round about when they heard how God had laid low, with sudden power, those two of His enemies who seemed most ferocious and powerful in their generation : ${ }^{8}$ I refer to him with whom we are now concerned, and the other of whom I spoke above. ${ }^{9}$ For in a

1 Eph. vi. 16. 2 Gen. iv. 6. 3 Exod. xv. I6.

4 P's. xxvii. 2 (vg.). 5 John iv. 37 .

6 While accepting the facts here narrated, so far as they were capable of being observed, one cannot ignore the probability that they were misinterpreted. It is quite possible that the offer of peace was made in good faith, and that Malachy and his friends were unduly suspicious when-they "foresaw gruile." The prince may have surrounded himself with armed men as a mere matter of prudence.
7 Susanna, 62.
${ }^{8}$ I,uke xvi. 8.
$9 \$ 23$. 
wonderful manner $\mathrm{He}$ took them both-one terribly punished in the body, ${ }^{1}$ the other mercifully changed in heart ${ }^{2}$-in the devices that they had imagined. ${ }^{3}$

27. These matters so accomplished, the bishop now began to dispose and order in the city all things pertaining to his ministry with entire freedom, but not without constant risk of his life. For though there was no one now who would harm him openly, yet the bishop had no place that was safe from plotters, and no time when he could be at ease; and armed men were appointed to guard him day and night, though he rather trusted in the Lord. ${ }^{4}$ But his purpose was to take action against the schismatic already mentioned, forasmuch as he was seducing many by means of the insignia which he carried about, persuading all that he ought to be bishop, and so stirring up the congregations ${ }^{5}$ against Malachy and the unity of the church. ${ }^{6}$ And thus he did; and without difficulty in a short time he so hedged up all his ways ${ }^{7}$ through the grace given unto him by the Lord, ${ }^{8}$ and which he had toward all, that that evil one was compelled to surrender, to return the insignia, ${ }^{9}$ and henceforth II 35 , (?) to be quiet in all subjection. ${ }^{10}$ Thus Malachy, albeit through many perils and labours, prospered day by day and was strengthened, abounding more and more in hope and the pozer of the Holy Ghost. ${ }^{11}$

1 Mulctatum in corfore.

3 Ps. x. 2.

5 Plebes.

7 Ilos. ii. 6.

9 This statement can hardly be regarded as accurate. Flann Ua Sinaich, keeper of the staff of Jesus, having died, Malachy purchased it on July 7, II 35 ; or, in other words, as we may suppose, bribed the new keeper to hand it over to him (A.F.MI.). Niall himself may have subsequently surrendered the Book of Armash.

10, Tim. ii. I I.

11 Rom. xv. 13 (vg.).-The success of Malachy in establishing peace in the latter years of his rule at Armagh may be attributed in part to the influence of a prince who is not mentioned in the text. 
$2 S$ (is). And God swept away, not only those who did evil to Malachy, but also those who disparaged him. A certain man, for example, who was in favour with the princes and magnates, and even with the king himself, because he was a flatterer and garrulous and mighty in tongue, ${ }^{2}$ befriended Malachy's opponents in all things, and impudently maintained their contention. On the other hand, when the saint was present, he zithstood him to the face, ${ }^{3}$ and when he was absent he disparaged him. Moreover he accosted him rudely everywhere, and especially when he knew that he was engaged in the more frequented assemblies. But he was soon visited with a suitable reward of his impudent tongue. The evil-speaking tongue swelled, and became putrid and worms stiarmed from it 4 and filled the whole blasphemous mouth. He vomited them forth incessantly for well-nigh seven days, and at length with them spued out his wretched soul.

29. Once when Malachy was speaking before the

Donough O'Carroll first appears in the Annals as chieftain of the men of Fearmmaigh (now represented ly the barony of Farney, co. Mona ghan), whom he led in an expedition against Fingal (the district north of Dublin) in I I33. He seems to have succeeded to the kingdom or lordship of Oriel (which included the present counties of Armagh, Monaghan anil Louth) on the death of Conor O'Loughlin ( May I I 36); for in $\mathrm{II}_{3} \mathrm{~S}$, "with the Oirgialla," he took part in an invasion of Meath. II is career was prosperous till I I 52 , when he assaulted the coarb of Patrick (Gelasius). In consequence he was attacked by the Cenél Eoghain, and expelled from Oriel. In I 55 he was imprisoned by Tighernan O'Rorke in Lough Sheelan, for six weeks; but he escaped and recovered his kingdom, and was present at the consecration of the Church of Mellifont Abbey in I157. IIe was murdered in I I6S. For his support of Malachy see Additional Note C, p. 17o.

1 This is obviously not the king mentioned in $\$ \$ 22,24,25$. The reference may he to Conor O'Loughlin, who was king of Oriel till he was murdered in Nay 136 (p) 40 , note 2 ), or his successor, Donough O'Carroll.
2 Ecclus. xxi. 7 .
3 Gal. ii. I I.
4 Exod. xvi. 20 (vg., inexact quotation). 
people and exhorting them, a certain unhappy wonıan dared to interrupt his discourse with evil cries, showing no respect to the priest and the Spirit ichich spake. ${ }^{1}$ Now she was of the impious race; and having briatl in her nostrils ${ }^{2}$ she vomited out blasphemies and insults against the saint, saying that he was a hypocrite, and an invader of the inheritance of another, and even reproaching him for his baldness. But he, modest and gentle as he was, anszered her nothing; ${ }^{3}$ but the Lord answered for him. The woman became insane by the judgement of the Lord, and crying out many times that she was being suffocated by Malachy, at length by a horrible death she expiated the $\sin$ of blasphemy. So this wretched woman, taking up against Malachy the reproach that had been made against ${ }$ Elisha, ${ }^{4}$ found to her cost that he was indeed another Elisha.

30. Further, because on account of a certain pestilence which arose in the city, he had solemnly led out a multitude of the clergy and people with the memorial of the saints, ${ }^{5}$ neither is this to be passed over, that when Malachy prayed the pestilence immediately ceased. Thenceforward there was none to murmur against him, for those who were of the seed of Canaan ${ }^{6}$ said, Let us flee from the face of Malachy, for the Lord fightetl

1 Acts vi. 10 (vg.).

2 Isa. ii. 22 ; cf. Job xxvii. 3 ; Wisd. ii. $2 .-$ The words might loe rendered "a spirit (spi)ritus) in her nostrils." The moaning is not clear. In the biblical passages in which the phrase occurs it indicates mortality. On the other hand, by the previous sentence St. Bernard suggeits that, in contrast to Malacliy, the woman spoke under the influence of an evil spirit.

3 Mark xiv. 6r. 42 Kings ii. 23.

5 Menoria sanctorum. Probably a reliquary. A reliquary preserved at Clogher in 1300 was known as the membra, which, according to one explanation, was the equivalent of memoriale scrinium, memorial shrine. See L.A.J. iv. 245. Cp. Oengus, p. 345 (s.a'. Menrae); Lightfoot, Clement of Rome, vol. i. p. 9 I.

6 Susanna, 56 . 
for him. ${ }^{1}$ But it was too late, for the wrath of the Lord, coming everywhere upon them, pursued them even unto destruction. ${ }^{2}$ How, in a few days, is their memorial perished with resounding noise ${ }^{3}$ howe are they brousht into desolation, they are consumed in a moment, they are punished for their iniquity. ${ }^{*} A$ great miracle to-day is the extinction of that generation, so quickly wrought, especially for those who knew their pride and power. ${ }^{5}$ And many other signs truly ${ }^{6}$ were there by which God glorified His name and strengthened His servant amidst labours and dangers. Who can worthily recount them? Yet we do not omit them all, though we have not ability to describe all. But that the sequence of the narrative niay not be interrupted we reserve to the end some that we propose to mention.

3I (19). So then Malachy, when within three years?

In a rezuard zeas rendered to the proud ${ }^{8}$ and liberty restored to the church, barbarism driven out and the customs of the Christian religion everywhere instituted anew, seeing that all things were at peace, began to think also of his own peace. And mindful of his design

1 Exod. xiv. 25.

3 l's. ix. 6 (vg.).

5 See Additional Note B, p. I66.

2 Deut. vii. 2 (vg.).

4 Ps. Ixxiii. 19.

6 John $\mathrm{xx} .30$.

7 This date is vague. Wut the period of three years must be reckoned from the death of Nuttongh (September 17, I I34), or from the subsequent ejection of Niall. Since stress is laid on the shortness, rather than the length of the period, we may therefore conclude that peace was established not long before October 1137, or, at any rate, after the beginning of that year. And as St. liernard believed that the inauguration of Gelasius "immediately" followed the resignation of Malachy, we may gather that both these events took place in I 37 . A.F.M. date Malachy's resignation in I 136 ; but the chronology of St. Bernard is to be preferred. See Additional Note C, pp. I68, 16 .

8 Ps. xciv. 2. 
he appointed in his own place Gelasius, ${ }^{1}$ a good man, and worthy of so great an honour, the clergy and people tacitly assenting, or rather supporting him because of the agreement. ${ }^{2}$ For apart from that it seemed altogether cruel. And when he had been consecrated and earnestly commended to the kings and princes, Malachy himself, renowned for miracles and triumphs, returned to his parish ${ }^{\mathbf{3}}$ but not to Connor. Hear the cause, which is worth relating. It is said that that diocese in ancient times had two episcopal sees, and that there were two bishoprics; an arrangement which seemed to Malachy preferable to the existing one. Hence those bishoprics which ambition had welded into one, ${ }^{4}$ Malachy divided again into two, yielding one part to another bishop and retaining the other for himself.

${ }^{1}$ Gelasius-in Irish Gilla meic Liag, the servant of the son of the poet-was born about IoS7. His father was apparently the poet of a Tyrone sept, named Dermot (O'Hanlon, Saints, iii. 965). About I I2I he was appointed abtot of Derry, and held that office till he became archbishop of Armagh in II37. He had a long episcopate and seems to have been a vigorous prelate. HIis age and infirmity (says Giraldus) prevented him from attending the Synod of Cashel in I 172. But he sulssequently visited Henry II. in Dublin. Thither he brought the white cow, whose milk was his only food (Giraldus, Expug. i. 35). He died March 27, 1 I 74, in his eighty-seventh year. For a Life of Gelasius, see Colgan, A.S.H. p. 772 .

2 See $\$ 2$ I.

3 I.c. diocese.

4 The two episcopal sees are evidently Connor and Down. But in early time there were many more sees than two in that district (see Reeves, p. ${ }_{13} 8$ ), and there is no evidence that any one of them was the seat of a diocesan bishop. But, even if it were so, St. liernard's statement that the two supposed dioceses were "welded into one" by some ambitious prelate prior to Malachy is unhistorical. A bishop of Connor and a bishop of Down both died in 11 7 , just seven years before Nalachy became bishop of the diocese which included these two places; and there is no trace of a bishop in either of them in the interval. The fact seems to be that the diocese of Connor or Down was constituted for the first time at the Synod of Rathbreasail in IIIO. It remained on paper until Malachy was appointed its first bishop. For the probable reason of Malachy's division of the diocese, see p. lvii. f. 
And for this reason he did not come to Connor, because he had already ordained a bishop in it $;^{1}$ but he betook himself to Down, separating the parishes as in the day's of old. ${ }^{2}$ O pure heart! O dove-like eye ! ${ }^{3}$ He handed over to the new bishop the place which seemed better organized, which was held to be more important, the place in which he himself had sat. Where are they that fight about boundaries, carrying on perpetual hostilities against one another for a single village? I know not if there is any class of men whom that ancient prophecy touches more than those: They hav'e ripped up the women with child of Gilead that they might enlarge their border. ${ }^{4}$ But this at another place. ${ }^{5}$

32. When Malachy was made bishop of Down, immediately according to his custom he was at pains to take to himself from his sons, for his comfort, a convent of regular clerics. ${ }^{6}$ And lo, again he girds himself,

1 This eamot be the true reason for Malaehy's ehoice of Down rather than Connor. If he had wished to go to Connor on his retirement from Armagh he could have consecrated a bishop for Down. It is more probable that his preference was due to his love for Bangor, where he resided during his first episcopate, and where he probably resided also when he was bishop of Down. But, however that may be, Bangor was necessarily under his jurisdietion as lishop of Down ; his eonnexion with it would have been severed if he had assumed the oversight of the new dioeese of Connor.

${ }^{2}$ Isa. li. 9 ; Amos ix. 11 .

${ }^{3}$ Cp. Cant. i. I 5 ; iv. i. ; v. 12.-St. Bernarl himself is said to have had "dove-like eyes" (I.P. v. I2) ; and the meaning of the phrase is explained thus: "In his eyes there shone a certain angelie furity and a dove-like simplicity (single-mindedness)" (ibid. iii. 1).

4 Amos i. I3.

5 Cp. $\$ 44$, p. $\$ 3$.

6 It has been commonly assumed that the house of this conventwhich obviously consisted of Augustinian canons (the only order of regular elerics reeognized at this period by the Roman Chureh: see Cone. Lat. I 39 , can. 9, Mansi xxi. 528)-was in Downpatrick. It has accordingly been identified with a monastery which in the Terrier of 16 I5 is deseribed as " the monastery of the Irish, hard by the Cathedral," and called "the church of the channons" (Reeves, 43, 23I). But it is not stated in the text to have been in Down. It seems more likely to have been the monactery of 
as though a new recruit of Christ, for the spiritual conflict; again he puts on the weapons that are mighty through God, 1 the humility of holy poverty, the rigour of monastic discipline, the quietness of contemplation, continuance in prayer. But all these things for a long time he was able to maintain rather in will than in deed. For all men came to him; not only obscure persons, but also nobles and magnates, hastened to commit themselves to his wisdom and holiness for instruction and correction. And he himself meanwhile went about; he went out to sow his seed, ${ }^{2}$ disposing and decreeing with all authority concerning ecclesiastical affairs, like one of the Apostles. And none suid unto him, By' what authority doest thou these things? 3 inasmuch as all saw the miracles and wonders which he did, ${ }^{4}$ and because zolhere the Spirit of the Lord is, there is liberti. 5

Bangor, which was destroyed in II27 (\$ I $\$$ ), and must have been reconstituted about this time. There is no indication in the Life that Malachy resided in Down, while there are several hints that lBangor was his headfuarters and that he was abbot of the community there as long ats he lived. (See p. 33, n. 1.) In other words l'angor was, in fact if not in name, the see of the diocese of Ulaiel, or Down. For th:s curious anomaly we have a parallel in the diocese of Tír Eoghain, tle see of which for a long period was at Maghera, the bishop, the while, being often styled bishop of Derry (Irish Church (uartirly, x. 225 ff.); and for the bishop of a diocese serving as abbot of his cathedral chapter of regular canons we may point to Carlisle (Trans. of Scottish Ecclesiological Sociaty, iii. 267 ff.), Louth (L.A.J. iv. I 43 ff.) and Christ Church, Dublin (ibid. I 45). That the canons of Bangor were at an carly period the bishop's chapter we have independent evidence. For in $\mathbf{2 4 4}$ the l'ope gave judgement in a cause which had been pending for some time between the prior and monks of Down and the abbot and canons of liangor, each of whom claimed that their church was catheiral (Theiner, p. 42). This claim on behalf of langor is easily explained if it was reckonal as the bishop's see in the time of Malachy.
12 Cor. x. 4.
"Matt. xvi. 23 ; Mark xi. 28 .
Acts viii. 6; John ii. 23.
2 Luke viii. 5 .
${ }^{5} 2$ Cor. iii. 17. 


\section{CHAPTER $V$}

The Roman Pilgrimage: the Miracles which were wrought in it.

33 (20). IT seemed to him, however, that one could not go on doing these things with sufficient security with. out the authority of the Apostolic See; and for that

I 139 reason he determined to set out for Rome, and most of all because the metropolitan see still lacked, and from the beginning had lacked, the use of the pall, which is the fullness of honour. ${ }^{1}$ And it seemed grood in his eyes $^{2}$ that the church for which he had laboured so much ${ }^{3}$ should acquire, by his zeal and labour, that privilege which hitherto it had not had. There was also another metropolitan see, which Cellach had constituted anew, though subject to the first see and to its archbishop as primate. ${ }^{4}$ For it also Malachy no less desired the pall, and that the prerogative which it had attained by the gift of Cellach should be confirmed by the authority of the Apostolic See. When his purpose became known it displeased both the brothers and the magnates and

1 The pall is a sort of eollar, made of lamb's wool, which every metropolitan is required to obtain from the Pope, and without which he cannot exercise his functions. From the end of the eleventh century it has been deseribed in papal bulls as the symbol of " the fullness of the pontifical office" (Catholic Encyclopedia, xi. 428). For the date of Malachy's decision to go to Rome, see p. 72, n. 3 .

${ }^{2}$ I Sam. xiv. 36, $40(\mathrm{vg}$.$) .$

3 Armagl.

4 Cashel, the seat of the kings of Munster. It was certainly the see of an archlishop in I I IO, when Malchus sulsecribed the Acts of Kathbreasail as archlishop of Cashel. For the date of its foundation see p. xxxv. f. 
people of the country; because all judged that they could not endure so long an absence of the loving father of them all, and because they feared he might die.

34. It happened meanwhile that his brother, Christian by name, died, ${ }^{1}$ a good man, full of grace and power. ${ }^{2}$

He was a bishop second tó Malachy in reputation,

I 139 , but in holiness of life and zeal for righteousness
June I 2 but perhaps his equal. His departure made all the more afraid, and rendered a parting from Malachy more grievous. They said, in fact, that they would in no wise assent to the pilgrimage of their only protector, since the whole land would be made desolate ${ }^{3}$ if in one moment it was bereaved of two such pillars. ${ }^{4}$ Therefore all, with one voice, opposed him, and would have used force but that he threatened them with divine vengeance. They refused to desist, however, till the will of God on this matter should be asked by the casting of a lot. He forbade it : nevertheless they cast the lot, but thrice it was found to give an answer in favour of Malachy. For they were not content with one trial, so eager were they to retain him.

a Christian, bishop of Clogher, was probably appointed bishop of that diocese in succession to Cinacth Ua Jiaigill, who died in II 35 (A.T:). Ile seems to have transferred the see of the diocese to Louth, a large part of the diocese of Armagh (in which Louth was situated) being placed under his jurisdiction. This arrangement was no doubt made by Malachy with the support of Donough $\mathrm{O}^{\prime}$ Carroll. See the document quoted in Additional Note C, p. I7O, L.A.J. iv, $\mathrm{I} 33 \mathrm{ff}$. and alsove, p. lix. Christian is commemorated in the contemporary Nartyrology of Gorman on June 12. The year of his death is stated $(A . F . M$.$) to have been$ II $_{3} \mathrm{~S}$. St. Bernard obviously supposed it to have taken place in II 39 (p. 70, 11. 2), and he appears to be right. For the work described in $\$ 32$ demands a longer period than can be allowed for it on the supposition that he divulged his scheme of visiting Rome before June 12, I I3S. Moreover hy that time he cannot have known that the papal schism had come to an end; for the Anti-pope dil not submit till May 29. C.p. P. 72, n. 3, and R.T.A. xxxv. 245 ff. For another notice of Christian, see p. 89, n. $\mathbf{1}$.

2 Acts vi. 8 (vg.), combined with Acts xi. 24.

${ }^{3}$ Jer. xii. I I.

* Gal. ii. 9 . 
Yielding at length they let him go, but not without lamentation and weeping and grat mourning. But that he should leave nothing imperfect he began to take measures by which he might raise up thi seed of his dead brother. ${ }^{2}$ And three of his disciples having been summoned to him he deliberated anxiously which should seem more worthy, or, in other words, more useful, for this work. And when he had scrutinized them one by one, he said, "I) you, Edan" (that was the name of one of them), "undertake the burden." ${ }^{3}$ And when he hesitated and wept, he proceeded, "Do not fear ; for you have been designated to me by the Lord; for just now

I saw in anticipation the gold ring with which

II to, you are to be espoused on your finger." 4 He assented, and when he had been consecrated Malichy set out on his journey.

35. And when he had left Scotland ${ }^{5}$ and reached

1 Matt. ii. IS.

a Deut. Xxv. 5 (vg.).

3 Edan O'Kelly was bishop of Louth till his death in I ISz

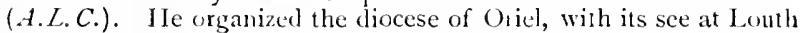
- corresponrling to the present diocese of Clogher-by the help of Donough O'Carroll. In conjunction with lim he founded the monastery of SS. P'eter and I'aul for Augustinian eanons at Knock, by Louth, consecrated by Malachy in 1148 ( A.F.M.; I.A.J. iv. 239 , and document quoted, p. I70). Close to it he also founded the Augustinian monastery of St. Mary, the church of which was the cathedral church of the diocese. On the carly history of this diocese see L.A.J. iv. I $29 \mathrm{ff}$.

4 This simple story was much developed in later times. Thus in a melieval regi,ter of Clogher we read that when Edan had anointed Christian on his dealbued "Malachy saw the ring which Christian wore leap to Edan's finger, and therefore lie consecrated him bishop" (L.A.J.iv. 239).

5 No particulars are given of the passage through Scotland. But Malachy probably sailed from Bangor to Cairngarroch $(\$ 40$, p. $7 \mathrm{~S}$, n. 4), and travelled thence by the shortest route through Carlisle to York. The kingdom of Scotland then extended southwards to the river Ribble at Gishum (\$ 69) and eastwards to the Tees (IVilliam of Newburgh, in Chron. of Stephen (R.S.), i. 7o). For a full discussion of his journeys, the results of which are here assumed, see R.I.A. $\times$ xxv. $23 \mathrm{~S}-243$. 
York, a priest, named Sycarus, ${ }^{1}$ steadfastly beholding $h \mathrm{~m}^{2}$ recognized him. For though he had not seen his face before, because he had the spirit of prophecy 3 he had received a revelation concerning him long ago. And now without hesitation he pointed him out with his finger to those who stood round him, saying, "This is he of zhom I had said that from Ireland there shall come 4 a holy bishop who knozeth the thoughts of man." 5 So the lamp could not be hid under a luushel, for the Holy Spirit who ligheted it ${ }^{6}$ brought it forth by the mouth of Sycarus. For also many secret things conceming the affairs of him and his companions were told him by Sycarus, all of which he acknowledged to be or to have been. But when the companions of Malachy went on to inquire about their return, Sycarus immediately replied-and the event afterwards proved the truth of the saying ${ }^{7}$ - that evidently very few of their number would return with the bishop. When they heard that they imagined that he apprehended death: but God fulfilled it in another way; for on his way back from the City he left some with us, and some in other places, to learn the rule of life ${ }^{8}$ and so, aciording to the apord of Sycarus, ${ }^{9}$ he returned to his own country with very few companions. So much concerning Sycarus.

36. In the same city of York he was visited by a man of noble rank according to the standard of the world,

1 This probably represents the Saxon name Sighere. Jocelin, who tells this story (I'ita $S$. IValtheni in A.A.SS., Aug., i. 255), says that Sycarus (or as the MSS. of his tract call him, Figanus) was a priest de Neubato (v.l. Neuvelt). i. $\varepsilon$., I suppose, of Newbald, a parish near Mirket Weighton, and about twenty-three niles from rork.

2 Acts xiv. 9

4 John i. 30 .

'Matt. v. 15 ; Mark iv. 21 ; Luke xi. 33. Gen. xli. 13 (vg.).

92 kings vi, $1 S$, etc.

3 Rev, xix. Io.

5 Ps. xciv. 11.

$8(p) \S 39$. 
Waltheof ${ }^{1}$ by name, then prior of the regular brothers at Kirkham, ${ }^{2}$ but now a monk, and father of the monks at Melrose, a monastery of our Order, ${ }^{3}$ who deroutly commended himself with humility to Malachy's prayers. And when he noticed that the bishop had many companions and few horses-for besides ministers ${ }^{4}$ and other clerks he had with him five presbyters, and only three horses-he offered him his own, on which he rode, saying that he regretted only one thing, that it was a pack-horse ${ }^{5}$ and a rough animal to ride. And

1 I'rinted text, Wallenus, obviously an error for Wralleuts (Wallez'zus), which is the reading of $A$. The name oceurs also in the form Wakleve. St. Waltheof was the younger son of Simon de St. Liz, earl of Northampton, by his wife Matilda, daughter of Waltheof, earl of Northumberland. After Simon's dealh Matilda married David, afterwards (1124) king of Scots. That Waltheof was the stepson of I avid $I$. is a fact not unimportant for readers of the Life of St. Malachy. After living for some time in Scotlind W'altheof retired to the Augustinian priory of St. Oswalcl, Nostal. Subsequently, but at what date seems to be unknown, he was ap. pointerl prior of Kirkham. But, desirous of a more austere life, lie resigned the priory, and entered a Cistereian house at Wardon, Bedfordshire. From it he soon migrated to Rievaulx in Yorkshire, and took the vows of the Order. On the deposition of lichard, first abtsol of Mlelrose, he was eleeted as his sueces vor in $I_{4} \mathrm{~S}$. IIe died August 3, I 599. (I Life by Jocelin in AA.S.S., Aug, i. 24S). II is visil to Nalachy proves that the fame of the latter had come to his ears-probably through the Scots who knew him at Lismore (§ $\$$ ). It indicates also that Malachy stayed at York lung enough to allow the news of his arrival to be sent 10 Kirkliam.

2 The ruins of Kirkham Abbey remain in the parish of Weston, about sixteen miles north-east of York. This house of Augustinian canons was founded in $112 \mathrm{I}$ by Walter Espec and his wife $\Lambda$ deline. The first pior was William, rector of Ga!ton, uncle of Espee. Dugrdale (vol. vi. I. pp. 207-209), overlooking Waltheof, mentions no other before II 190 .

3 The first Cistercian monastery in Scotland, founded in 1136 by David I. It was a daughter of kievaulx, from which, as we have seen, Waltheof was called to be its abbot. Its church of St. Mary was consecrated July 28 , 1146 . It is on the lank of the Tweed, not far from Old Nelrose, the site of a community founted in the seventh century, of which St. Cuthbert was a member. See James A. Wade, Mistory of Melrose.

4 Deacons.

5 K'uncinus, the Ola English rouncy (Chancer, /'rol. 390). from this incident the inference is elear that durmg the whole 
he added, "I would have given it more willingly if it had been better; but, if you think it worth while, take it with you, such as it is." "And I," replied the bishop, "accept it the more willingly the more valueless you proclaim it, because nothing can be of no value to me which so precious a will offers;" and, turning to his compantons, "Saddle this horse for me, for it is suitable for me, and will suffice for a long time." This done, he mounts. And at first he considered it rough, as it was, but afterwards, by a wonderful change, he found that it suited him well and ambled pleasantly. And that there might not fall on the ground any part of the word which he had spoken, ${ }^{1}$ till the ninth year, the year in which he died, ${ }^{2}$ it did not fail him, and became an excellent and very valuable palfrey. And-that which made the miracle more evident to those that saw-from being nearly black it began to grow white, and after no long time $^{\mathbf{3}}$ there was scarcely a whiter horse to be found than it.

37 (21). To me also it was granted to see the man on that journey, ${ }^{4}$ and by the sight of him and by his word

journey to Rome and back most of Malachy's comparions were always on foot, and that the parly went at a walking pace.

1 I Sam. iii. 19. Cp. Matt. x. 29.

2 An important date. Since Malachy died on November 2, I I48, he must have reacherl York not earlier than November I139. For reasons for putting the visit somewhat later see R.I.A. xxxv. $247 \mathrm{f}$.

3 "Within a few days," says Jocelin in his version of the story! Sce AA.SS. l.c.

* After leaving York Malachy no doubt followed approximately the line of the Roman road known as Erming Street to London and Canterbury. Thanks to the preservation of the Itinerary of Archbishop Sigerie on his journey from Rome to Canterbury in 990 (Stubbs, Memorials of St. Dunstan (R.S.), pp. 39I-395), to our knowledge of the rontes of travellers contemporary with Malachy, and to the rare mention in the Life of places through which he passed, we can follow him almost step by step from Canterlury to Rome and back. IIe probably sailed from Dover, and landed on the French coast at or near Wissant. Thence he went by Arras, Rheims, Châlons-sur-Marne, Bar-sur-Aube, Lausanne, Matigny, 
I was refreshed, and I rejoiced as in all riches; ${ }^{1}$ and I, in turn, though a sinner, found srace in his sight" II4O, then, and from that time up to his death, as I said in the Preface. ${ }^{3}$ He also, deigning to turn aside to Clairvaux, ${ }^{4}$ when he saw the brothers was

and over the Great St. Bernard to Ivrea. Then he followed the beaten tract through Vercelli, l'avia, Piacenza, Pontremoli, Lucca and Viterbo to Rome. On the whole journey, from langor to Rome and back, the company traversed about 3000 miles on land, hesides crossing the sea four times. Allowing for stoppages at Rome, Clairvaux and elsewhere, and for a weekly rest on Sunday, Dlalachy must have been absent from I reland alout nine months. For details see R.I.A. xxxv, $23 \mathrm{Sff}$. The marginal dates are hased on that investigation, ard are to be regarded merely as approximations.

1 l's. cxix. 14. 2 Gen. xxxiii. Io, etc. 3 l'ref. \$2.

4 Malachy prolnably "turned aside" from the main road at liarsur-Aube, from which Clairvaux is distant eight miles. A few words may be said about this famous monastery and its first abhot. liermard, the son of a nol, leman named Tescelin and his saintly wife Aleth, whose memory exercised a powerfut influence on the lives of her children, was born at Fontaines, a mile or two from Dijon, in Iogo. In Oct. I II I he persuaded his brothers and many of his filends to embrace the religious life. Early in the following year the whole band, thirty in number, entered the austere and now declining community which had been established in IogS at Citeaux, twelve miles from Dijon. Their arrival was the beginning of the prosperity of the great Cistercian Order. In I I 5 liernard was sent out, with some brothers, by the abbot, Stephen IIarding, to found a daughter house on the river Aube, in a valley which had once been known, from its desolation, as the Valley of Wormwood. After incredible hardships a monastery was built, and the place was so transformed by the labours of the monks that henceforth it deserved its newer name of Clara Vallis, or Clairvaux. The community rapidly increased in numbers; and in 1133 , in spite of the opposition of the albot when the proposal was first made, the buikding of a laige monastery on a different site was begun. It was probably far advanced when Malachy arrived in Il 40 (Vacandard, i. 413, 423). It was just completed when he came again in I $14 \mathrm{~S}$ (cee p. I 43, n. 5). St. Bernard died on August 20, II 53. At this time he was the most powerful ecelesiastic in Europe, not excepting his nominee Pope Imocent II. (see p. $72, \mathrm{n} .3$ ). Doubtless the main purpose of Malachy's visit to Clairvatux was to secure St. Bernard's support of the petition which he was about to present to the Pope. For further information about St. Bernard the reader may consult V.P., Vacandard, J. Cotter Mlorison, The Life and Times of St. Bernard, Abbot of Clitiranex (186S), and Richard S. Storrs, Bornard of Clairiaur, the Times, the Man, and his Hork (1892). 
deeply moved; and they were not a little edified by his presence and his speech. So accepting the place and us, and gathering us into his inmost heart, he bade us farewell and departed. And crossing the $\Lambda$ lps he came to Irrea, $\mathbf{1}$ a city of Italy, where he immediately healed the little son of his host who zaras sick and ready to dic.

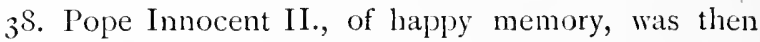
in the Apostolic See. ${ }^{3}$ He received him courteously, and displayed kindly pity for him on account of

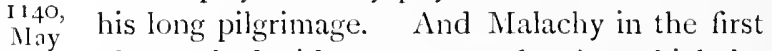
place asked with many tears for that which he had fixed most deeply in his heart, that he might be allowed to live and die at Clairvaux, with the permission and blessing of the chief Pontiff. He sought this, not forgetful of the purpose for which he had come, but inlluenced by the longing for Clairvaux which he had brought with him. ${ }^{4}$ But he did not obtain his request, because the apostolic man decided that he should be employed to more profitable advantage. He was not, however, wholly disappointed of his heart's desire, ${ }^{5}$ since it was granted him if not to live, at least to die there.

1 Yforia. Its ancient name was Eporedia. From it there are two routes across the Alps, by the Great St. Bernard and the Little st. Bernaril respectively.

2 Luke vii. 2.

3 On the death of Pope Ionorius II. (February I4, II3O) two I'opes were elected loy different groups of cardinals, Innocent I I. and Anacletus II. St. Bernard espoused the cause of the former, and by his unliring efforts almost all the sovereigns of Europe were enlisted on his side (see Vacandard, chaps. x.-xiii., xviii. ; Storrs, pp. 523-540; Morison, pp. I49-165, 209-2I3). But the schism lasted for eight years. At length A nacletus died (January 7, I13S), and the surrender of his successor, Victor IV., on May 29, II 3 (Ef. 3I $)$, Iefi Innocent in undisputed occupation of the papal chair. The news of the pacification was not announced in Scottand till the end of September (Richard of Hexham, I70). It probably reached Ireland a little later. It must have been after he was assured of the end of the schism that Malachy proposed his journey to Kone, $i . e$. at the end of 113 S or in 1139 .

\footnotetext{
- Quo wenerat.
}

5 l's. xxi. 2. 
He spent a whole month in the City, visiting the holy places and resorting to them for prayer. During that time the chief Pontiff made frequent and careful inquiry of him and those who were with him concerning the affairs of their country, the morals of the people, the state of the churches, and the great things that God had wrought by him in the land. And when he was already preparing to return home the Pope committed his own authority to him, appointing ${ }^{*}$ him legate throughout the whole of Ireland. For Bishop Gilbert, who, as we have mentioned above, was then legate, had intimated to him that by reason of age and infirmity of body he could no longer discharse the duties of the office. ${ }^{1}$ After this Malachy prayed that the constitution of the new metropolis ${ }^{2}$ should be confirmed, and that palls should be given him for both sees. The privilege of confirmation he soon received ; "but regarding the palls," said the chief Pontiff, "more formal action must be taken. You must call together the bishops and clerks and the magnates of the land and hold a general council ; and so with the assent and common desire of all ye shall demand the pall by persons of honest repute, and it shall be given you." 'Then he took his mitre from his own head, and placed it on Malachy's head, ${ }^{3}$ and more, he gave him the stole

1 Luke xvi. 2 (rg.).-For Gilbert see p. 47, n. 3. Patrick, successor of filluert in the see of Limerick, was consecrated by Theobald, archbishop of Canterbury, who was himself consccrated on January S, i 39 (W. Stubbs, l'eg. Sac. Ansl. ${ }^{2}$, p. 45). His profession of obedience (Ussher, $P .565$ ) appears in the roll of professions at Canterlury immediately before that of Uhtred of

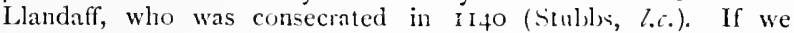
assume that Gilbert resigned his see and his legatine commission at the same time, this gives I $39^{-40}$ as the date of Malachy's journey, in agreement with the hint of St. Bernard in $\$ 36$. It is possible that Gilbert's resignation of his office as legate was sent to Rome by Malachy.

2 Cashel. See p. 65, note 4.

3 Fleming in 1623 saw a mitre of Malachy at Clairvau, which was sulposed to have been the one placed on his head by fnnocent. 
and maniple which he was accustomed to use in the offering; and saluting him with the kiss of peace he dismissed him, strengthened with the apostolic blessing and authority.

39. And returning by Claisvaux he bestowed on us $a$ second benediction. ${ }^{1}$ And sighing deeply that

II.40, it was not allowed him to remain as he longed August to do, he said, "Meamwhile I pray you to keep these men for me, that they may learn from you what they may afterwards teach us." And he added, "They will be to us for a seed, and in this seed shall the nations be blessed, ${ }^{2}$ even those nations which from ancient days have heard the name of monk, but have not seen a monk." 3 And leaving four of his most intimate companions ${ }^{4}$ he departed: and they, when

(Orbiers, ten leagues away, hi: woolen drinking cup was preserved : it was in a ltathern case, adorned with Irish interlacings (/rish Eiclesiastical hicort, vii. 63).

1 C.p. 2 Cor. i. 15.

2 Gen. xxii. IS; xxvi. 4.

3 Compare the passage concerning a brother who had been sent from Clairvaux to Sweden in $11_{43}$, and had founded a daughter monastery there: "The lord [St. Bernard] sent to his faithful servant learned and discreet persons from the parts of Germany and England, by whom the discipline of monastic religrion founded in that kingdom increased and bore wortly fruit among peoples who had indeed heard the name of monk, but had never before scen a monk" (V.P. vii. 54). It was literally true that no monastic communities had previously existed in Sweden (C. II. Robinson, Conzersion of Eurote, p. $4 \mathrm{Saf}$. Cp. Vacandard, ii. 4 I6). Hit the passage before us cannot be construed as an assertion that Ireland was in like case; for in $\$ 12$ menlion is made of the "monks" of Bangror in the time of Comgall. St. Bernarel (or Malachy, if the words are really his) must be taken to mean simply that the so-called monks of the decadent contemporary Church of Ireland were not monks in the true sense of the word. (Cp. Lett. iii. \$2). There is nothing to be saill for the explanation suggested by Lanigan (iv. I 14 ) that the "nations" are nations other tlan the Irish, who had no monks. For where were those nalions to whom the Irish might send colonies of monks? The fact is that the Latin worl for " nations" (gentes) may quite well mean here what it cerlainly means in $\$ 42$, the Irish tribes.

4 Ile left others in other Cistercian houses (\$35). 
they were proved and found worthy, were made monks. After a time, when the saint was now in his own country, he sent others, ${ }^{1}$ and they were dealt with in like manner. And when they had been instructed for some time and had applied their hearts unto wisdom, ${ }^{2}$ the holy brother Christian, ${ }^{3}$ who was one of themselves, was given to then

I 42 to be their father, and we sent them out, adding from our own a sufficient number for an abbey."

1 Cp. Letter i. § I.

2 Ps. xc. I 2.

3 Gilla Críst Ua Condoirche was prolably a native of the distriet of Bangor ( $\mathrm{I} 4)$. I Ie seems to have been one of the four who were left by Malachy at Clairvaux; and, as is here stated, he was the first abbot of Mellifont. Ile seems, however, to have proved not well suited for the office, for he was sent back to Clairvaux for further instruction (1.etter iii. \$3). Some of the Clairvaux l,rothers (if not all of them) refused to remain in Ireland, and it is perhaps hinted that the cause of their return was dissatisfaction with his ad. ministration (ib. \& 2). About I I 50 he was promoted to the bishoprie of Lismore, and at the Synod of Kells in I I 52 he appeared as papal legate (Keating, iii. 317). He was present at the consecration of the church of Nellifont Abbey in $1157(A . U$.) As legate he also presided at the synod of Cashel in II 72 (Giraldus, Expug. i. 34). IIe died in 1 I 86 (A.L.C.). Felix, bishop of Lismore, attended the Lateran Council of II79 (Mansi, xxii. 217). Christian must therefore have resigned his see before that date.

4 Mellifont Abbey, the ruins of which still remain in a secluded valley, beside the stream known as the Mattock, about two miles from the Boyne, and five miles west of Drogheda. Some time after Malachy returned to Ireland he wrote to St. Bernard, asking him to send two of the four brothers who had been left at Clairvanx to select a sile for the ablhey. This request was declined (Lett. i. \$ I), and the site-donbtless the gift of Donough O'Carroll (see the doenment quoted p. 170) - was apparently chosen by Malachy himself. In II 42 (C.M.A. ii. 262, Cly'n's Annals, Annals of Boyle), the four brothers, together with a contingent of monks from Clairvaux, arrived, and the monastery was founded, with Christian as its first abbot (Lett. ii.). Considerable progress was made with the buildings, and endowments poured in. But after a while it became necessary to send Christian back to France for further instruction, and the Clairvaux monks went with him, never to return. In due time Christian resumed his office as albbot, and with him came one Robert, to assist him in the work of building and organization (Lett. iii ). The Abley Church was not eonsecrated till I157, nine years after Malachy's death $\left(A . U_{0}\right)$. Meilifont remained the principal Cistercian louse in Ireland up to the Reformation. After the dissolution (1539) it was granterl, with its possessions, to Sir Edward 
And this abbey conceived and bare five danghters, ${ }^{\mathbf{1}}$ and the seed being thus multiplied ${ }^{2}$ the number of monks increases from day to day according to the desire and prophecy of Malachy. Now let us return to the order of the narrative.

40 (22). Malachy having set out from us had a prosperous journey through Scotland. And he found King David, ${ }^{3}$ who is still alive to-day, in one of his castles $;^{4}$

Moore, ancestor of the earls of Drogheda. The only poritions of the monastery which remain in a fair state of preservation are the Chapter House and the Lavabo. The latter belongs to the original building. Excavations made about twenty years ago revealed the ground plan of the entire monastery, most of which was of later date than Malachy. Traces were discovered of the foundation of the eastern portion of the original church, about forty feet west of the east wall of the structure which later took its place. It had six chapels at the east end, four of which were apsidal (71st Riport of Commissioners of Public Works, lreland, p. II).

1 I Sam. ii. 21. - The five daughters were apparently bective (de Beatitudine) founded in I 147 , Boyle, I $147-S$, Monasternenagh, I I 48 , Baltinglis (de Valle Salutis), I I 4 , and Inislounaght (Janauschek, Origines Cisterienses, Vindobonire, $\left.{ }_{1} S_{77}, p p .70,92,1_{13}\right)$. The last-namid seems to have been in existence in $1_{4} \$$ (see $\$ 64$ ), and it may have been an off-shoot of Mellifont, though at an early date it was suljject to Monasternenagh (ibid. 13i). Gougaud (Les Chrétientés Celtiques, I91 I, p. 364) gives Shrule (de Benedictione Dei) the fifth place; but it appears to have been founded ( 1 150?) after the Lifi was written (Janauschek, P. II4).

: Cp. Gen. xxii. I 7 ; xxvi. 4.

3 David I. of Scotland, son of Malcoln Canmore and St. Margaret, the sister of Edgar the Atheling. Ile was born in 10\$4. II is sister Matilda was the wife of Henry I. of England; and thus he was uncle of Matilda, the empress, for whom he fought against Stephen, though Stephen's wife, Queen Matilda, was also his niece. In I I 3 Davil married Matilda, the widow of Simon de St. Liz, earl of Northampton (cp. p. 69, n. 1). IIe succeeded Alexander I. in 1124 and died in I 153 . As the founder of several Scottish dioceses and as having introfuced the Cistercian Order into his lingdom he had much in common with St. Malachy.

${ }_{4}$ This is probally an error. There is no record that David I. harl any castles in Galloway ; and the chronicles seem to show that at this period his principal residences were at Roxburgh and Carlisle. The narrative suggests that the castle referred to was in the immediate neighbourhood of Cruggleton (p. $7 S, n .1$ ), and it was probably the predecessor of that of which the scanty ruins-believed to be of thirteenth-century date-remain on the coast not far from the 
and his son reas sick nigh unto death. ${ }^{1}$ And when Malachy entered the king's house he was honourably received by him and prevailed upon by humble entreaty that he rould heal his son. ${ }^{2}$ He sprinkled the youth with water which he had blessed, and fastening his eyes upon him said, "Trust me, my son; you shall not die this time." He said this, and on the next day, according to his word, there followed the cure, and after the cure the joy of the father and the shouting and noise of the whole exulting family. The rumour zeent forth ${ }^{4}$ to all, for what happened in the royal house and to the king's son rould not be hid. ${ }^{5}$ And lo, everywhere there resounded thanksgizing and the i'vice of praise, ${ }^{6}$ both for the salvation of their lord, and for the novelty of the miracle. This is Henry ; ${ }^{7}$ for he still lives, the only son of his father, a brave and prudent knight, taking after his father as they say, in follozeing after righteousness ${ }^{8}$ and love of the truth. And both loved Malachy, as long as he lived, because he had recalled him from death. They asked him to remain some days; but he, shunning renown,

village. They are on a peninsula of such natural strength that we many suppose it was in very early times the site of a fortress (Fourth Report of Commission on Ancient llonnments in Scotland, vol. i. p. 144). I'ossibly, as has beell suggested, David was there as the guest of Fergus, lord of Galloway (I I24-116I), to whom, subsequently to the Battle of the Standard (August 22, i I3S), and probably not long before this visit of Malachy, he had been reconciled after a long estrangement (Agnew, Hercdilary Shoriffs of Galloway, I 893 . vol. i. p. 58 ).

1 Phil. ii. 27 (inexact quotation).

3 Acts iii. 4 .

5 Mark vii. 24.

2 John iv. 47.

+ Luke vii. 17

6 lsa. li. 3 (vg.).

7 The only son of David: "a man gentle and pious, a man of sweet nalure and of pure heart, and worthy in all things to be born of such a father" (Ailred of Rievaulx, in A. O. Anderson, Scottish Annals from Enstish Chronilers, p. 156). IIe died before his father, in May or June 1152 (John of Hexham). Two of his sons become kings of Scots, Malcolm IV. and William I.

8 Ron. ix. 3o, etc. 
was impatient of delay, and in the morning went on his way.

As he passed, therefore, through the village called Cruggleton, a dumb girl met him. While he prayed the string of her tonsue was loosed and she spake plain. ${ }^{2}$

Then he entered the village which they call St. Michael's Church, ${ }^{3}$ and before all the people cured a woman who was brought to him, mad and bound with cords; and when he had sent her away restored he went on.

But when he came to Portus Lapasperi, ${ }^{4}$ he waited there for a passage some days; but the time of delay

1 Crugeldum. Cruggleton is on the west coast of Wigtown Bay, in the parish of Sorby, Wigtownshire. In passing through this village Malachy male a détour, probably in order to visit King I avid, which considerably lengthened his journey.

2 Mark vii. 35.

3 The parish church of Mochrum, Wigtownshire, as Sir IIerbert Maxwell informs me, was anciently dedicated to St. Michael. Thus the village called Si. Michael's Church is undoubtedly Kirk Mochrum, which clusters round the church, and through which every traveller from Cruggleton to Cairngarroch (see next note) must pass. It is twelve miles from Cruggleton.

+ Lapasperi is obviously the gen. of Lafasper, a corruption of Lapis asper (rough stone). This seems to be a Latin rendering of Cairngarroch (=Carn garbh), a name which occurs three times on the shores of Wigtownshire. One of the places so called, on the west coast of Luce Bay, may be set aside. The other two are seven or eight miles apart, within sight of the Bangor coast, and nearly equidistant from it; one in the parish of Stoneykirk, the other (now known as Rough Caim) in the parish of Geswalt. The late Sir Andrew Agnew (op. cit. p. 59) regarded the latter as the place referred to in the text on grounds which do not seem conclusive. Cairngarroch in Stoncykirk is to be preferred for two reasons: it is more easily approached from inland than its rival; and it has impressed its name on the actual coast-line, which the other has not done; "Cairngarroch Bay " is equivalent to Port Cairn garbh, and that to the Portus Lapasteri of the text. This identification was first proposed by O'Hanlon (p. 8I) ; and its probability is increased now that the position of St. Nichael's Church has been fixed (sce preceding note). But one of his arguments in favour of it, based on the name of the parish, is fallacious; for "Stoneykirk" has nothing to do with stones: it is a late corruption of Stciniekirk = St. Stephen's Church. 
did not pass idly. In the interval an oratory is constructed of twigs woven into a hedge, he both giving directions and himself working. When it was finished he surrounded it with a wall, and blessed the enclosed space for a cemetery. The merits of him who blessed, the miracles, which are said to be wrought there frequently to this day, sufficiently declare.

$4 \mathrm{I}$. Hence it came that they were in the habit of carrying thither from the neighbouring places those that were infirm and diseased, and many were healed. ${ }^{1}$ A woman paralysed in all her limbs, brought thither on a waggon, returned home on foot, having waited only one night in the holy place, not in vain, for the mercy of the Lord. $^{2}$

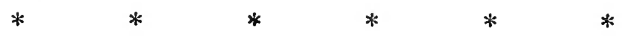

Let these incidents-a few out of many-suffice with reference to that place; for now we must proceed with what remains.

1 Mark i. 32, 34 .

2 For the passage here omitted see $A$ plendix, p. I 7 I. 


\section{CHAPTER VI}

'St. Malachy's Apostolic Labours, Praises and Miracles.

42 (23). Malachy embarked in a ship, and after a prosperous voyage landed at his monastery of

I ifo, Bangor, ${ }^{1}$ so that his first sons might receive the first lenefit. ${ }^{2}$ In what state of mind do you suppose they were when they received their father-and such a father - in good health from so long a journey? No wonder if their whole heart gave itself over to joy at his return, when swift rumour soon brought incredible gladness even to the tribes ${ }^{3}$ outside round about them. In fine, from the cities and castles and hamlets they ran to meet him, and wherever he turned he was received with the joy of the zhole land. ${ }^{4}$ But honour is not to his taste. He exercises his office as legate; many assemblies are held in many places, so that no region, or part of a region, may be defrauded of the fruit and advantage of his legation. He sow's beside all zoaters; ${ }^{5}$ there is not one who can escape from his sedulous care. Neither sex, nor age, nor condition, nor [religious] profession is held in account. ${ }^{6}$ Everywhere the saving seed is scattered, everywhere the heavenly trumpet sounds. He scours every place, everywhere he breaks in, with the saerd of his tongue unsheathed to execute vengeance upon

1 Of which, it appears from this and other passages (see p. 33, 11. I), he was still abbot.

2 Cor. i. 15.

4 Ps. xlviii. 2.

3 Gentihus.

5 Isa. xxxii. 20.

${ }^{6}$ Cp. Serm. ii. § 3. Terhaps here, as in that passage, we should read person (persona) for profession (professio). 
the nations and funishments ufon the peofies. 'The terror of him is on them that do evil. ${ }^{2}$ He cries unto the unrighteous, deal not unrighteously, and to the avicked, lifl not ut the horn." Religion is planted everywhere, is propagated, is tended. His eyes are ufon them, ${ }^{4}$ his care is for their necessities. In councils, which are everywhere held, the ancient traditions are revived, which, though their excellence was unclisputed, had fallen into disuse by the negligence of the priests. And not only are the old restored, new customs are also devised : and whatsoever things he promulgated are accepted as though issued from heaven, are held fast, are committed to writing for a memorial to posterity. Why should we not believe those things were sent from heaven which so many heavenly miracles confirm? And that I may make what has been said credible, let me touch on some of these miracles in a few words. For who can enumerate all? Though I confess I had rather dwell on those things which can be imitated than on those which can only excite wonder.

43 (24). And in my judgement the first and greatest miracle that he exhibited was himself. ${ }^{5}$ For to say nothing of his inner ma ${ }^{6}{ }^{6}$ the beauty and strength and purity of which his habits and life sufficiently attested, he so bore himself even outwardly in a uniform and consistent manner, and that the most modest and becoming, that absolutely nothing appeared in him which could offend the beholders. And, indeed, he who offends not in word, the same is a perfect man. ${ }^{7}$ But yet in Malachy,

1 Ps. cxlix. 6, 7 .

3 P's. Ixxv. 4 (vg.).

2 P's. xxxiv. $16: 1$ Pet. iii. I 2.

4 P's. xxxiv. I5; I l'et. iii. 12.

5 St. Bernard's secretary, Geoffrey, recalls ihis sentence ( $I: P$. iii. I). He mentions the saint's many miracles and then proceeds, "But, as he himself says, in commendation of St. Malachy, the first and greatest miracle that he displayed was himself." About half of the present section is embodied by Gerlatus in his description of the chatacter of Godscalcus (MI.G.HI., Scr. xvii. 7oo).

6 Eph. iii. I6.

7 Jas. iii. 2. 
who, though he observed with unusual care, ever detected, I will not say an idle wort, but an idle nod? Who ever knew his hand or his foot to move without purpose? Yea, what was there that was not edifying in his gait, his mien, his bearing, his countenance? In fine, neither did sadness darken nor laughter turn to levity the joyousness of his countenance. ${ }^{2}$ Everything in him was under discipline, everything a mark of airtue, a mle ${ }^{3}$ of $\cdot$ perfection. Always he was grave, but not austere. Relaxing at times, but never careless; neglecting nothing, though for a time ignoring many things. Quiet often, but by no means at any time idle. ${ }^{4}$ From the first day of his conversion to the last of his life, he lived without personal possessions." He had neither menseriants nor maidserants, ${ }^{6}$ nor villages nor hamlets, nor in fact any revenues, ecclesiastical or secular, even when he was a bishop. There was nothing whatever ordained or assigned for his episcopal mensa, by which the bishop might live; for he had not even a house of his own. But he was almost always going about all the parishes ${ }^{7}$ serving the Gospel, ${ }^{8}$ and living of the Gospel, ${ }^{9}$ as the Lord appointed for him when he said, The labourer is worthy of his hire. ${ }^{10}$ Except that more frequently, making the Gospel itself zeithout charge, ${ }^{11}$ as a result of the labours of himself and his companions, he brought with him

1 Matt. xii. 36 .

2 Cp. Serm. ii. $\$ 4$.

${ }^{3} \mathrm{Cp}$. Consecratio in Ordering of Deacons (Gregorian Sacra. mentary).

4 Cp. Serm. ii. $\$ 4$.

5 This statement must be accepted with some reserve. Malachy must have had personal property while he was coarb of Patrick. And accordingly Serm. i. $\$ 6$, connects his voluntary poverty with his episcopate in Down, and above (\$2I) his departure from Armagh is represented as a retmin to poverty. The context shows that St. liernard is here thinking of the period when he was legate.
${ }^{6}$ Gen. xxxii. 5, etc.
${ }^{8}$ Cp. Rom. i. 9.
7 I. $\ell$. dioceses.
10 Luke x. 7.
9 I Cor. ix. 14.
11 I Cor. ix. Is; cp. Serm. ii. § I. 
that by which he might sustain himself and those with laboured aeith him in the zeork of the ministry. ${ }^{1}$ Further, if at times he had to rest he did so in the holy places which he himself had scattered through the whole of Ireland; but he conformed to the customs and observances of those with whom it pleased him to tarry, content with the common life and the common table. There was nought in his food, nought in his clothing, by which Malachy could be distinguished from the rest of the brethren; to such a degree, though he was greatest, did he humble himself in all things. ${ }^{2}$

44. Then, when he went out to preach, he was accompanied by others on foot, and on foot went he himself, the bishop and legate. That was the apostolic rule; and it is the more to be admired in Malachy because it is too rare in others. The true successor of the Apostles assuredly is he who does such things. But it is to be observed how he divides the inheritance aith his brothers, ${ }^{3}$ equally descendints of the Apostles. They lord it among the clorgy'; he, though he ze'cs free from all men, made himself the servant of all." 'They either do not preach the Gospel and yet eat, or preach the Gospel in order that they may eat; Malachy, imitating Paul, eats that he may preach the Gospel. ${ }^{\circ}$ They supfose that arrogance and gain are godliness ${ }^{7}$ Malachy claims for himself by inheritance labour and a load. ${ }^{8}$ They believe themselves happy if they enlarge their borders;" Malachy glories in enlarging charity. ${ }^{10}$ They gather into

1 Phil. iv. 3 combined with Eph. iv I2; cp. Acts xx. 34 .

2 Matt. xviii. 4, combined with Ecclus. iii. 20.

${ }^{3}$ Luke xii. I 3 . ${ }^{4}$ I l'et. v. 3 (vg.).

5 I Cor. ix. 19.

"Cp. De Dil. I7: "Paul did not preach the Gospel that he might eat, but ate that he might preach the Gospel ; for he loved not food lut the Gospel." The reference is of course to I Cor. ix.

7 Tim. vi. 5.

- Amosi. I3.

\& Opus el onus.

$10 \mathrm{C}$ ). 2 Cor. vi. I I. 
barns ${ }^{1}$ and fill the wine-jars, that they may load their tables; Malachy collects [men] into deserts and solitudes that he may fill the heavens. They, though they receive tithes and first-fruits and oblations, besides customs and tributes by the gift of Casar and countless other revenues, nevertheless take thought zohat they shall eat or what they shall drink; " Malachy haing nothing of such things, yet makes many rich ${ }^{3}$ out of the storehouse of faith. Of their desire and anxiety there is no end ; Malachy, desiring nothing, knows not how to think about the morrow. ${ }^{4}$ They exact from the poor that which they may give to the rich; Malachy implores the rich to provide for the poor. They empty the purses of their subjects; he for their sins heaps altars ${ }^{5}$ with vows and peace-offerings." They build lofty palaces, raise $u_{p}$ towers and ramparts to the heavens. ${ }^{7}$ Malachy, not having where to hay his head, does the work of an earngelist. ${ }^{9}$ 'They ride on horse' ${ }^{10}$ with a crowd of men, who cat bread for nought, and that not their own; ${ }^{11}$ Malachy, hedged round with a college of holy brothers, groes about on foot, bearing the bread of ansels, ${ }^{12}$ with which to satisfy the hungry souls. ${ }^{13}$ They do not even know the congregations; ${ }^{14}$ he instructs them. They honour powerful men and tyrants; he punishes them. $\mathrm{O}$, apostolic man, whom so many and so striking signs of his apostleship ${ }^{15}$ ennoble! What wonder, then, if he has wrought wondrous things when he himself is so wonder-

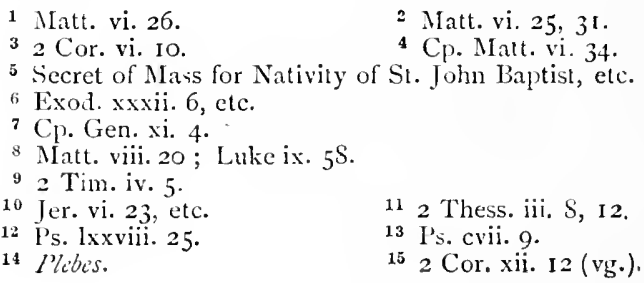


ful? Yet truly not he but God in him. ${ }^{1}$ Moreover, it is said, Thou art the God that doest zuonders. ${ }^{2}$

$45(25)$. There was a woman in the city of Coleraine ${ }^{3}$ who had a demon. Malachy was called ; he prayed for the possessed; he commanded the invader and he went out. But his iniquity was not yet fully satisfied, and he entered into an unhappy woman who happened to be standing by. And Malachy said, "I did not release that woman from your grasp in order that you might enter this one; go out of her also." He obeyed, but went back to the former woman; and driven forth from her once more, he again went into the second. So for some time he vexed them alternately, fleeing to and fro. Then the saint, indignant that he was mocked by a demon, summoned up his spirit, and shouted; and when he had made an attack on the adversary with all the forces of faith, he drove the demon away from both, no less vexed than those whom he had vexed. But do not suppose, reader, that the delay which he caused the saint was due to his own strength : it was permitted by the divine dispensation, evidently in order that by this as well the power of the evil one as the victory of Malachy might be made more manifest.

Hear now what he did elsewhere, but not by reason of his presence. Assuredly what he had power to accomplish when absent, he could do also when present.

1 Cp. I Cor. xv. Io.

2 Ps. Ixxvii. 14.-The following narrati es of Malachy's miracles are not in chronologieal order. They are arranged aecording to their eliaraeter. Thus the first four $\left(\$ \$ 45,4^{6}\right)$ are instances of his power over demons.

3 Coleraine is said to have been founded by St. Patriek: and it was certainly a religious establishment at least as early as the sixth century (Adamnan, i. 50). One of its erenachs died in I I 22 $(A . F . M$. ). The word "eity" implics that the community was still in existence. 
46. In a district of the northern part of Ireland a sick man lay in his house. His sickness was beyond doubt due to the evil influence of demons. For one night he heard them talking; and one said to another, "See that this wretched man does not touch the bed or bedding of that hypocrite, and so escape from our hands." The man perceived that they were speaking of Malachy, who, as he remembered, had not long before passed a night in that house. And the bedding was still in its place; and taking courage, with his utmost effort he began to crawl, weak in body but strong in faith. And lo, in the air there was clamour and shouting: "Stop him, stop him, hold him, hold him ; we are losing our prey." But, carried on by faith and the desire to escape, the more they shouted the more he hastened to the remedy, straining with knees and hands. And when he reached the couch, and went up on it, he rolled himself in the bed-clothes, and heard the wailing of them that lamented, "Alas, alas, we have betrayed ourselves, we have been deceived, he has escaped." 1 And quicker than a word, there left him the terror of the demons and the horror which he suffered, and with them all his sickness.

In the city of Lismore a man vexed by a demon was delivered by Malachy.

Also once, when he was passing through Leinster, an infant was brought to him who had a demon, and he was brought back whole.

In the same region he ordered a mad woman, ${ }^{2}$ bound with cords, to be loosed and to be bathed in water which he blessed. She washed and was healed.

1 Compare the story of St. Gall listening to the conversation of the demon of the mountain and the demon of the waters, told in Stokes's Celtic Church in Ireland, p. I45, from the Life of St. Gall in Mi.G.H., Scr. i. 7 .

2 The first of three miracles of healing the insane. 
Another woman also in Saul, ${ }^{1}$ a region of Ulaid, ${ }^{2}$ who was tearing her own limbs with her teeth, he cured by praying and touching her.

There was a madman, who predicted many things to come. His friends and neighbours brought him to the man of God, bound strongly with cords, because his very madness had made him strong to do hurt and excceding terrible. Nalachy prayed, and immediately the sick man was healed and released. This was done in a certain place, the name of which we omit because it has a very barbarous sound, as also have many others. $^{3}$

At another time in the above-mentioned city of Lismore, ${ }^{4}$ the parents of a dumb girl ${ }^{5}$ brought her to him in the midst of the street as he passed, asking him with much entreaty that he would deign to help her. Malachy stood and prayed; and he touched her tongrue with his finger and spat ${ }^{6}$ upon her mouth, and sent her away speaking.

47 (26). Going out of a certain church he met a man with his wife, and she could not speak. And when he was asked to have mercy on her, he stood in the gate, the people surrounding him; and he gave a blessing upon her, and bacle her say the Lord's Prayer. She said it, and the people blessed the Lord.

1 In Lecale, co. Down, near Downpatrick. There St. Patrick made his first convert, and there he died. It is not easy to explain why St. Bernard calls it a "region." See further, p. I I 3, n. 3.

2 Ulaid was a district which included the greater part of the present county of Down, and the southern part of Antrim.

3 For a similar avowal by Jocelin, who wrote in the same century as St. Bernard, and other illustrative passages, see Adamnan, p. 4.

- See $\$ \$$, and above in this section.

5 The first of three healings of dumb persons.

6 Mark vii. 33 . 
In a city called Antrim ${ }^{1}$ a certain man lying on a bed, now deprived for twelve days of the use of his tongue, at the bidding of the saint, who visited him, recovered his speech and received the Eucharist; and so fortified he breathed his last breath in a good confession. ${ }^{2} \mathrm{O}$, fruitful olive tree in the house of God! ${ }^{3} \mathrm{O}$, oil of gladness, ${ }^{4}$ giving both anointing and light! By the splendour of the miracle he gave light to those who were whole, by the graciousness of the favour he anointed the sick man, and obtained for him, soon about to die, the saving power of confession and communion. ${ }^{5}$

One of the nobles came in to him, hating someruhat to say to him; ${ }^{6}$ and while they were speaking, full of faith ${ }^{7}$ piously stole three rushes from the couch on which Malachy sat, and took them with him : and God wrought many things as a result of the pious theft, by that man's faith and the sanctity of the prelate.

By chance he had come to a city called Cloyne. ${ }^{8}$ And when he was sitting at table a nobleman of that city came in and humbly prayed him for his wife, who was pregnant, and had passed the appointed time of parturition, so that all wondered, and there was none

1 The word "city" implies that there was a religious community at Antrim. That this was the case is proved by the round tower which still remains, and other evidence (Reeves, p. 63). But apparently the Annals do not refer to any monastery or church at that place. See, however, U.A. and A.F.M. at 1096 for a possible exception.

2 I Tim. vi, I3.

4 Ps. xlv. 7 .

6 Luke vii. 40.

3 Ps. lii. S (vg.).

5 Cp. Serm. ii. $\$ 8$.

7 Acts vi. 5 .

8 I'rinted text, Conuama, no MS. variants being recorded in the margin : perhaps a misprint for Clonuama. Mabilon has Duvania and $\mathrm{K}$ Duenuania. A seems to read Clueumania. All these variants point to Cluain zama (the meadow of the cave), the Irish name for Cloyne, which is undoubtedly the place referred to (see next note). The next two miracles are concerned with childbirth. The first of them may have been related to St. Bernard by Marcus, the author of Tundale's Vision (see Friedel and Mcyer, La I'ision de Tonaale, p. iv., and above p. lxv. n. 3). 
who did not believe that her life was in danger. With him also Nehemiah, ${ }^{1}$ the bishop of that city, who was sitting next to him, made request to Malachy, and others also as many as were present reclining together. Then he said, "I pity her, for she is a good and modest woman." And offering the man a cup which he had blessed, he said, "Go, give her to drink, and know that when she has taken the draught of blessing ${ }^{2}$ she will bring forth without delay, and without danger." It was done as he commanded, and that very night there followed that which he promised.

He was sitting in a plain with the count of Ulaid, dealing with certain matters, and a sreat multitude ${ }^{3}$ was about them. There came a woman who had long been with child. She declared that contrary to all the laws of nature she had already been pregnant for fifteen months and twenty days. Malachy having pity for this new and unheard-of trouble, prayed, and the woman was delivered. Those who were present rejoiced and wondered. For all saw with what ease and rapidity she brought forth in the same place, and the sad portent of birth denied was changed to a happier marvel.

${ }_{4} 8(27)$. There happened in the same place an event with a similar miracle but a different issue. He saw a man who was reported to be consorting publicly with his brother's concubine; and he was a knight, a servant of the count. And publicly accosting the incestuous man he displayed himself to him as another John, saying, It is not lazeful for thee to have thy brother's

1 Nehemiah Moriarty, who died in 1149 ( $A . F . M$.), being then, it is said, 95 years old (Tundale, p. 5). In rundale (p. 53 f.) he is one of four bishop; who were will St. Patrick in Paradise, the others being Cellach, Malachy and Christian O'Morgair. IIe is there (pp. 5, 54) ealled bishop of Cloyne (Cluanonsis).

2 Cp. I Cor. x. 16.

3 Lulie vi. I7. 
concubine. ${ }^{1}$ But he, nevertheless, in his turn displaying himself to Malachy as another Herod, not only did not hearken to him, but even answered him haughtily, and before them all swore that he would never put her away. 'Then Malachy, much agitated, for he was vehemently zealous for righteousness, said, "Then God shall separate you from her against your will." Paying little heed the man went away at once in a rage. And meeting the woman not far from the crowd which was in the place, he treated her evilly and with violence, as though he wholly belonged to Satan to whom he had a little before been delivered. ${ }^{2}$ Nor was the crime hidden. The damsel who accompanied the lady ran back to the house (for it was not far from the place), and, breathless, announced the wickedness that had taken place. At the word her brothers, who were at home, emraged at the dishonour done to their sister, rushed thither with all haste and slew the enemy of virtue, taken in the very place and act ${ }^{3}$ of crime, piercing him with many wounds. The assembly was not yet dismissed when, lo! his armour-bearer proclaimed what had happened. And all wondered that the sentence of Malachy had taken such speedy effect. When this word was heard all evildoers (for there were many in the land) feared and, being terrified, purified themselves, zeashing their hands in the blood of the ungolly. ${ }^{4}$

49 (28). Dermot the count, ${ }^{5}$ who had now for a long time lain on his bed, he sprinkled with blessed water, and caused him to rise up without delay, and so strong

1 Mark vi. 18.

3 John viii. 4 .

2 I Cor. v. 5 ; I Tim. i. 20.

4 l's. lviii. Io (vg.).

5 P'robably Dermot MacMurrough, who became king of Lcinster in 1126 , and died in 1171 . He was driven out of his kingdom in I 166, and then invited the Anglo-Normans to come to his aict. The result was the conquest of Ireland. His character merits the description which sil. Bernard gives of it. 
that he mounted his horse on the spot, surpassing assuredly the hope of himself and of his friends-rebuking him severely at the same time because he was a bad man sering his belly ${ }^{\mathbf{1}}$ and his appetite immoderately.

In the town of Cashel a man came before him with his paralysed son, asking that he should be healed." And Malachy, praying briefly, said, "Go thy" z'ay": the son shall be made whole." 3 He went, and on the morrow he returned with his son, who was nevertheless by no means whole. Then Malachy rose and standing over him prayed at greater length, and he was made whole. And turning to the father he said, "Offer him to God." The man assented, but did not keep his promise; and after some years his son, now a young man, relapsed into the same state, no doubt because of his father's disobedience and his violation of the pledge.

Another man came from a long distance, when Malachy was in the borders of Munster, bringing to him his son, who was entirely deprived of the use of his feet. When he inquired how this had happened to him, he said, "As I suspect, by the malignity of demons"; adding, "It was they, if I mistake not, who, when he was playing in a field, caused a slees to fall upon him, ${ }^{4}$ and when the child awoke he found himself so." Saying this, he poured forth his petition with tears, and earnestly sought help. Malachy pitying him prayed, bidding the sick boy in the meantime to sleep there upon the ground. He slept, and he arose whole. Because he had come from far ${ }^{5}$ he kept him some time in his company, and he used to walk with him.

5o. In the monastery of Bangor a certain poor man was maintained by the alms of the brothers; and he received a small sum every day, for performing some

1 kom. xvi. IS.
3 John iv. 50.
2 The first of three healingrs of paralysis.

1 Gen. ii. 2 I.
5 Mark viii. 3 . 
office in the mill. He had been lame for twelve years, creeping on the ground with his hands, and dragging his dead feet after him. Him Malachy found one day before his cell, sad and sorrowful, and asked him the cause. And he said, "You see how for a long time I am miserably troubled and the hand of the Lord is ufon $m e^{\prime}{ }^{1}$ and lo, to increase my distress, men who ought to have had pity, rather laugh at me and cast my wretchedness in my teeth." And when he heard him, moved with compassion, he looked up to hearen, ${ }^{2}$ at the same time raising his hands. Having said a short prayer he entered his cell, and the other rose up. And standing upon his feet he wondered if it was true, suspecting that he was in a dream. ${ }^{3}$ But he began to move with slow steps, for he did not altogether believe that he could walk. At length, as it arere araking out of a deep slect, ${ }^{4}$ he recognized the mercy of the Lord upon him; he walked firmly, and returned to the mill leaping and exulting and praising God. When those saw him who had before seen and known him they wre filled with zoonder and amawement, ${ }^{5}$ supposing it to be a spirit. ${ }^{6}$

Malachy likewise healed a dropsical man by praying, who remained there in the monastery and was appointed shepherd.

5 I. A city of Ireland called Cork was without a bishop. They proceeded to an election; but the various parties did not agree, each, as is usual, wishing to appoint their own bishop, not God's. ${ }^{7}$ Malachy came

1 Acts xiii. I I, etc.

3 C. Acts xii. 9.

- Acts iii. S-ro.

2 Mark vii. 34.

4 Gen. xlv. 26 (vg.).

6 Mark vi. 49.

7 This implies that the liocese of Cork had already been founded. But we cannot be sure that St. Bernard is correct when he says that the clergy and people met to elect a bishop, in view of his inability elsewhere (\$ I 9) to distinguish bishops from abbots. It is at least possible that there was strife between different septs concerning the appointment of a coarb of Barre, founder of the church of Cork. 
to the place when he heard of the disagreement. Calling together the clergy and people he took pains to unite the hearts and desires of the opposing parties. And when they had been persuaded that the whole business ought to be entrusted to him, on whom in a very special manner lay the care of that as also of the other churches ${ }^{1}$ throughout Ireland, ${ }^{2}$ immediately he named to them, not any of the nobles of the land, ${ }^{3}$ but rather a certain poor man whom he knew to be holy and learned; and he was a stranger. ${ }^{4} \mathrm{He}$ was sought; and it was announced

Malachy may have taken advantage of the strife to nominate a ruler who belonged to no sept in the district and who would allow himself to be consecrated bishop. The vacancy may have been made by the

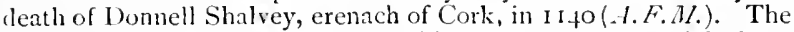
word erenach is sometimes used at this period where we might have expected to find $a b l o l$ (cp. $A . F . M$. I I 37 , quoted in Addlitional Note C, p. 167).

${ }_{1}{ }_{2}$ Cor. xi. 28.

2 Evidently Malachy was now papal legate. The date of the incident is therefore not earlier than II 40 .

3 It would seem that it was taken for granted that one of the lcading men of a sept would be appointed, according to prevalent custom, exemplified in the case of Armagh. This suggests that the vacant office was that of abbot. There would be nothing surprising in the selection of a "poor man," who was not a local magnate, as diocesan bishop.

'Luke xvii. 16, 18. - This was probably Gilla Aedha Ua Muidhin, who attended the Synod of Kells in 1152 as hishop of Cork (Kealing, iii. 31 7 ), and died in $1172(A . U$.). Since he attainert "a good old age" there is no reason why he should not have been consecrated as early as I I40 or II4I. IIe had been a monk of Errew in Lough Con, co. Mayo ( 1.7 . I I72), and was therefore "a stranger," i. e. not a native of NI unster. He is called a " poor man," no doubt, for the same reason as Malachy himself $(\$ 24)$, because he had embraced the life of voluntary poverty. He had a reputation for piety and learning, for the Annals describe him as "full of the grace of God" (A.U.), and " the tower of devotion and wisdon and virginity of Ireland "(A.T.). And if the tradition is tuustworthy that he was abbot of St. John the Evangelist at Cork, lounded by Cormac Mac Carthy "for pilgrims from Connaught" (see the charter of Dermot Nac Carthy printed in Gibson's Ilistory of Cork, ii. 348 ), and that it received its later mame of Gill $\Lambda$ bbey from him, we can explain how he came to be near at hand when the election was taking place. 
that he was lying in bed, and so weak that he could in no wise go out unless carried in the hands of those who ministered to him. "Let him rise," said Malachy; " in the name of the Lord I command it; obedience will save him." What was he to do? He wished to obey, but he thought himself unfitted; for though it should be possible for him to go, he dreaded to be a bishop. So with the will to be obedient twin enemies were contending, the load of weakness and the fear of the burden. But the first conquered, the hope of salvation being given him as an aid. Therefore he made the attempt, be moved, tested his power, discovered that he was stronger than usual. Faith increased along with power, and again faith made stronger gave in its turn increase of power. Now he was able to rise unassisted, now to walk somewhat better, now not even to perceive weariness in walking; at length, to come to Malachy without difficulty and quickly, unaided by man. He promoted him, and put him into the chair, with the applause of clergy and people. This was done without question, because neither did they dare to oppose the will of Malachy in any way, seeing the sign which he had wrought; nor did he hesitate to obey, being made surer, by so evident a proof, of the will of God.

52 (29). A certain zoman was diseased with an issue of blood; ${ }^{1}$ and she was of noble birth and very dear to Malachy, though by reason of the nobility rather of her character than of her descent. When she was entirely failing, her strength no doubt being exhausted with her blood, and was now near the end, she sent to the man of God, in order that - the only thing that remained to be done-he might help her soul who should see her no

2 Matt. ix. 20.-In this and the next two sections we have three miracles wrought on women; one at the point of death, another dead, and the third spiritnally dead. 
more in the body. When Malachy heard it he was troubled, because she was a woman of virtue, and her life fruitful in work and example. And perceiving that he could not reach her in time he called Malchus, for he was young and active (he is that brother of $\Lambda$ l, bot Christian whom we mentioned above), ${ }^{1}$ and said, "Haste, take her these three apples on which I have invoked the name of the Lord; I am assured of this, that when she tastes these she sluall not taste of death before she sees us, ${ }^{2}$ though we shall follow somewhat more slowly." Malchus hastened as he was commandecl, and when he came he went in to the dying woman, showing himself another servant of Elisha, except that his work was more efficncious. ${ }^{3}$ He bade her take that which Malachy had blessed and sent to her, and to taste it if by any means she could. But she was so refreshed when she heard Malachy's name, that she was able to obey, and indicated by a nod (for she could not speak) that she wished to be raised up for a little while. She was raised up, she tasted; she was strengthened by what she tasted, she spoke, and gave thanks. And the Lord caused a deep sleep to fall upon her, ${ }^{4}$ and she rested most sweetly in it, having long ceased to enjoy the benefit of sleep, or to partake of food. Meanwhile her blood was staunched ${ }^{5}$ and awaking after a while she found herself whole, ${ }^{;}$but she was still weak from long fasting and loss of blood. If in any degree the cure was not complete, ${ }^{7}$ on the following day the wished for presence and appearance of Malachy made it perfect.

$53(30)$. A nobleman lived in the neighbourhood of

1 See $\$ 14$.

2 Matt. xvi. $2 S$; Mark ix. I ; Luke ix. 27.

3 See 2 Kings iv. $29 \mathrm{ff}$.

5 Luke viii. 44.

+ Gen. ii. 2 I.

${ }^{6}$ Cp. Mark v. 2 .

7 Si quominus. The text seems to he corrupt. A friend suggests the emendation sed quomilus deficeret.

I. 
the monastery of Bangor, whose wife aras sick nigh unto death. ${ }^{1}$ Malachy, being asked to come down ere she died, ${ }^{2}$ to anoint the sick woman rith oil, ${ }^{\mathbf{3}}$ came down and went in to her; and when she saw him she rejoiced greatly, animated by the hope of salvation. And when he was preparing to anoint her, it seemed to all that it ought rather to be postponed to the morning; for it was evening. Malachy assented, and when he had given a blessing over the sick woman, he went out with those who were with him. But shortly afterwards, suddenly there was a cry made, ${ }^{4}$ lamentation and great wailing through the whole house, for it was reported that she had died. Malachy ran up when he heard the tumult, and his disciples followed him. And coming to the bed, when he had assured himself that she had breathed her last, he was greatly troubled in mind, blaming himself that she had died without the grace of the sacrament. And lifting up his hands to heaven he said, "I beseech thee, Lord, I have done very foolishly. I, even I, have sinned, ${ }^{5}$ who postponed, not she who desired it." Saying this he protested in the hearing of all that he would not be comforted, ${ }^{6}$ that he would give no rest to his spirit, ${ }^{7}$ unless he should be allowed to restore the grace which he had taken away. And standing over her, all night he laboured in his groaning; and, instead of the holy oil, flooding the dead woman with a great rain of tears, ${ }^{8}$ he bestowed on her such a substitute for the unction as he could. Thus did he; but to his companions he said, " Watih and pray"." So they in psalms, he in tears,

1 Piil. ii. 27 (inexact quotation).- The story told in this section was a favourite of St Charles Borromeo (Alban Butler, Lizes of Saints, ed. IIusenbeth, ii. 607).

2 John iv. 49.

4 Matt. xxv. 6.

6 Gen. xxxvii. 35 .

8 P's. vi. 6 (vg.); Jer. xlv. 3 .

3 Cp. Mark vi. 13; Jas. v. 14.

5 I Chron. xxi. 8, I7.

72 Cor. ii. 13 ; cp. Jer. xlv. 3.

9 Matt. xxvi. $4 \mathbf{I}$, etc. 
passed a night of vigil. And when the morning came the Lord heard His saint, for the Spirit of the Lord was making intercession for him, who maketh interession for the saints with groanings that cannot be uttered. ${ }^{1}$ Why more? She who had been dead opened her eyes, ${ }^{2}$ and, as those do who wake from a deep sleep, rubbing her forehead and temples with her hands, she rose upon the bed, and recognizing Malachy, devoutly saluted him with bowed head. And mourning being turned into $j o y,{ }^{3}$ amazement took hold of all, both those who saw and those who heard. And Malachy also gave thanks and blessed the Lord. And he anointed her, nevertheless, knowing that in that sacrament sins are forgizen, and that the prayer of faith saves the sick. ${ }^{4}$ After this he went away, and she recovered, and after living for some time in good health, that the glory of God should be made manifest in her, ${ }^{5}$ she accomplished the penance which Malachy had enjoined upon her, and again fell asleep $^{6}$ in a good confession, ${ }^{7}$ and passed to the Lord.

54 (3). 'There was also a woman whom a spirit of anger and fury ${ }^{8}$ dominated to such an extent that not only her neighbours and relatives fled from her society, but even her own sons could scarcely endure to live with her. Shouting, rancour and a mighty tempest ${ }^{9}$ wherever she was. Violent, fiery, hasty, terrible with tongue and hand, intolerable to all, and hated. Her sons, grieving both for her and for themselves, dragged her into the presence of Malachy, setting forth their lamentable complaint with tears. But the holy man, pitying both the sickness of the mother and the trouble of her sons, called her aside, and made urgent inquiry

\footnotetext{
1 Rom. viii. 26.

3 John xvi. 20.

5 John ix. 3.

7 I Tim. vi. 13.

${ }^{9}$ Ps. 1.3 (vog.).
}

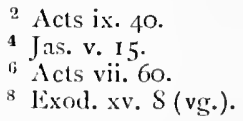


whether she had ever confessed her sins. She replied, "Never." "Confess," said he. She obeyed; and he enjoined penance on her when she made confession, and prayed over her that Almighty God might give her the spirit of meeliness, ${ }^{1}$ and in the name of the Lord Jesus bade her to be angry no more. Such meekness followed that it was plain to all that it was nothing else than a marvellous change effected by the right hand of the Most Hish.' It is said that she is still living to-day, and is so patient and gentle that, though she used to exasperate all, now she cannot be exasperated by any injuries or insults or afflictions. If it be allowed me, as the Apostle says, to be fully persuaded in my ozen mind, ${ }^{3}$ let each accept it as he will; for me, I give it as my opinion that this miracle should be regarded as superior to that of raising the dead woman, mentioned above, inasmuch as there the outward, but here the innor man 4 was restored to life. And now let us hasten to what remains.

55. A man who as regards the world was honourable, as regards God devout, eame to Malachy and complained to him concerning the barrenness of his sml, ${ }^{5}$ praying that he would obtain for him from Almighty God the grace of tears. And Malachy, smiling because he was pleased that there should be spiritual desire from a man of the world, laid his cheek on the cheek of the other as though caressing him, and said, "Be it done unto you as you have asked." "From that time rizers of zaters ran dozen his eyes ${ }^{7}$ so great and so nearly incessant that the phrase of Scripture might seem applicable to him : A fountain of sardens, a wall of living zoaters." 8
1 I Cor. iv. 2 I.
3 Rom. xiv. 5 .
5 P's, xxxy. I 2 (vg.).
"Matt. viii. 13, combined with John xv. 7 .
7 l's. cxix. 136 .
2 Ps. lxxvii. 10 (vg.).
\& Eph. iii. I6 ; cp. 2 Cor. iv. 16.
$\checkmark$ Cant. iv. 15. 
There is an island of the sea in Ireland, from of old fruitful of fishes $;^{1}$ and the sea there abounds in fish. By the sins of the inhabitants, as it is believed, the wonted supply was taken away, and she that had many children zocs zouxed feeble, ${ }^{2}$ and her own great usefulness utterly dwindled away. While the natives were grieving, and the peoples taking ill the great loss, it was revealed to a certain woman that a remedy might be effected by the prayers of Malachy; and that became known to all, for she herself proclaimed it. By the will of God it happened that Malachy arrived. For while he was going round and filling the region with the Cospel, he turned aside thither that to them also he might impart the same grace. ${ }^{3}$ But the burbarous people, ${ }^{4}$ who cared more for the fishes, ${ }^{\circ}$ demanded with all vehemence that he would deign to regard rather the sterility of their island. And when he answered that it was not for that he had come, but that he desired to catch men rather than fish, ${ }^{6}$ yet seeing their faith ${ }^{7}$ he kneeled doren on the shore and frayed ${ }^{8}$ to the Lord that, though they were unworthy of it, he would not deny them the benefit granted long before, since they sought it again with so great faith. The prayer zent $u p,{ }^{9}$ there came up also a multitude of fishes, ${ }^{10}$ and perhaps more fruitful than in ancient days; and the people of the land continue to enjoy that abundance to this day. What wonder if the prajer of a righteons man which penetrates the heavens, ${ }^{11}$ penetrated the aly'sses, ${ }^{12}$ and called forth from the depth of the sea so great supplies of fish?

1 Here and in $\$ 56$ we have two miraculous draughts of fish.

2 I Sam. ii. 5.

4 Acts. xxviii. 2.

${ }^{3}$ Cp. Rom. i. II.

${ }^{6}$ Cp. Luke v. Io.

8 Acts xxi. 5.

9 Acts x. 4 .

5 Cp. I Cor. ix. 9.

7 C. Mark ii. 5 ; Luke v. 20.

11 Ecclus. xxxv. 2 I (inexact quotation).

${ }^{12}$ Cp. P's. cvii. 26 (vg.). 
56. There came, on one occasion, three bishops into the village of Faughart, ${ }^{1}$, which they say was the birthplace of Brigit the virgin ; ${ }^{2}$ and Malachy was a fourth. And the presbyter who had received them with hospitality, said to him, "What shall I do, for I have no fish ?" And when he answered that he should seek them from the fishermen, he said, "For the last two years no fish have been found in the river $;^{3}$ and for that reason the fishermen also are all scattered and have even abandoned their art." And Malachy replied "Command them to let doann the nets 4 in the name of the Lord." It was done, and twelve salmon were caught. They lowered them a second time, and catching as many more they brought to the tables both an unlooked-for dish and an unlooked-for miracle. And that it might be clear that this was granted to the merits of Malachy, the same sterility nevertheless continued also for the following two years.

1 Faughart is a parish north of Dundalk.

2 Apparently the only authority earlier than St. Bernard which makes Faughart the birthplace of St. Brigit is her fourth Life (i. 6, Trias, 547).

3 The Kilcurry liver. 


\section{CHAPTER VII}

He do's battle for the faith; he restors feace among those who were at variance; he takes in hand to build a stone church.

57 (32). There was a certain clerk in Lismore whose life, as it is said, was good, but his faith not so. He was a man of some knowledge in his own eyes, and dared to say that in the Eucharist there is only a sacrament and not the fact ${ }^{1}$ of the sacrament, that is, mere sanctification and not the truth of the Body. On this subject he was often addressed by Malachy in secret, but in vain; and finally he was ealled before a public assembly, the laity however being excluded, in order that if it were possible, he should be healed and not put to confusion. ${ }^{2}$ So in a gathering of clerics the man was given opportunity to answer for his opinion. And when with all his powers of ingenuity, in which he had no slight skill, he attempted to assert and defend his error, Malachy disputing against him and convieting him, in the judgement of all, he was worsted ; and he retired, put to confusion by the unanimity though not sentenced to punishment. ${ }^{3}$

1 Rem. This may have been a follower of Berengarius, who in his reeantation in 1059 anathematized the heresy that the bread and wine "after consecralion are merely a sacrament and not the true Body and Blood of our Lord Jesus Christ" (Mansi, xix. 900).

2 Compare St. Bemard's method with Abélard, V.P. iii. I3; and for his dealing with a brother who did not believe in transubstantiation, ibid. vii. 8,9 .

3 I follow the printed text : de consensu confusus quidem exiit, sed non correptus. But Mabillon, supported by $A$, has "he retired from the assembly confouncled, but not brought to the right opinion" (de consintu . . . non correctus). K reads de conuentu . . non correptus. 
But he said that he was not overcome by reason, but crushed by the authority of the bishop. "And you, Malachy," said he, "have put me to confusion this day without good reason, speaking assuredly against the truth and contrary to your own conscience." Malachy, sad for a man so hardened, but grieving more for the injury that was done to the faith, and fearing dangerous developments, called the church together, ${ }^{1}$ publicly censured the erring one, publicly admonished him to repent, the bishops and the whole clergy urging him to the same effect. When he did not submit, they pronounced an anathema upon him as contumacious and proclaimed him a heretic. But not aroused from sleep by this he said, "You all favour the man, not the truth ; I do not accept persons so that I should forsake the truth." 2 To this word the saint made answer with some heat, "The Lord make you confess the truth even of necessity;" and when he replied "Amen " the assembly was dissolved. Burnt with such a branding-iron he meditated flight, for he could not bear to be of ill repute and dishonoured. And forthwith he departed, carrying his belongings; when lo, seized with sudden weakness, he stood still, and his strength failing he threw himself on the ground in the same spot, panting and weary. A vagabond nadman, arriving by chance at that place, came upon the man and asked him what he did there. He replied that he was suffering from great weakness and unable either to advance or to go back. And the other said, "This weakness is nothing else than death itself." But this he spake not of himself, but ${ }^{3}$ God fitly rebuked by means of a madman him who would not submit to the sane counsels of men of understanding.

1 It would seem from this that Malachy was acting as legate. The date is therefore after I I 40.

2 Prov. xxviii. 2 I (vg).

3 John xi. 5 I. 
And he said, "Return home, I will help you." Finally with his guidance he went back into the city : he returned to his right mind and to the mercy of the Lord. In the same hour the bishop was summoned, the truth was acknowledged, error was renounced. He confessed his guilt and was absolved. He asked for the viaticum, and reconciliation was granted; and almost in the same moment his perfidy was renounced by his mouth and dissolved by his death. So, to the wonder of all, with all speed was fulfilled the word of Malachy, and with it that of the Scripture which say's, "Trouble gines understanding" to the hearing.". 1

$5^{S}$ (33). Between the peoples of certain regions there once arose grievous discord..2 Malachy was importuned to make peace between them, and because he was hindered by other business he committed this matter to one of the bishops. He made excuse and refused, saying that Malachy, not he, had been sought for, that he would be despised, that he was unwilling to take trouble to no purpose. "Go," said Malachy, "and the Lord be zeith you." 3 He replied, "I assent, but if they will not hear me, know that I will appeal to your Fatherhood." Smiling, Malachy said, "Be it so." Then the bishop, having called the parties together, dictated terms of peace; they assented and were reconciled to one another, security was given on both sides, and peace was established; and so he dismissed them. But one party, seeing that their enemies had become careless and were unprepared, because peace having been made they suspected no harm, said among themselves, each man to his neighbour," "What are we minded to do? Victory

${ }^{1}$ Isa. Xxviii. 19 (vg.).

2 In $\$ 38-62$ we have three stories in which Malachy appears as a peacemaker.

3 I Sam. xvii. 37, combined with I Chron. xxii. 16.

4 Gen. xi. 3 (v's.). 
and vengeance on our foes is in our grasp "; and they began to attack them. What was happening became known to the bishop, and hastening up he charged their chief with wickedness and guile, but he treated him with contempt. He invoked the name of Malachy against him, and he paid no attention to it. Laughing at the bishop he said, "Do you suppose that for you we ought to let those go who did evil to us, whom God leath delivered into ourhands?" 1 And the bishop, remembering the conversation which he had had with Malachy, weeping and reailing," turned his face towards Malachy's monastery ${ }^{3}$ and said, "Where art thou, man of God, where art thou? Is not this, my father, what I told thee of? Alas, alas, I came here that I might do good and not evil ; and behold, through me all are perishing, these in the body, those in the soul." Many things in this manner said he as he mourned and lamented, ${ }^{\mathbf{4}}$ and he urged and addressed Malachy, as though he were present, against the wicked. But meanwhile the impious men did not cease to attack those with whom they had made peace, so as to destroy them; and behold there was a lying spirit in the mouth of certain men to deceive them. ${ }^{5}$ And these men met them in the way announcing that a raid had been made into their lands by their adversaries, that all things were being consumed with the edge of the sword, ${ }^{6}$ and that their goods were being laid waste, and their wives and children taken and led away. When they heard this they returned in haste. The hindmost followed the first, not knowing zohither they zeent ${ }^{7}$ or what had happened; for they had not all heard

1 Judg. xvi. 24.

2 Mark v. 38 .

3 This expression indicates that Malachy had a special relation to one monastery. It can liardly have been any other than Bangor.

4 Matt. xi. 17.

${ }^{5} 1$ Kings xxii. 22 ; 2 Chron. xviii. 2 I.

"Josh. vi. 2 I ; Judg. iv. 15, etc.

7 Heb. xi. 8 . 
the men who spoke. And when they came and found none of those things which had been told them they were confounded, taken in their own wickedness $;^{1}$ and they knew that they had been given up to the spirit of error, ${ }^{2}$ on account of the messenger of Malachy whom they deceived and his name which they despised. ${ }^{3}$ Further, the bishop, when he heard that the traitors were foiled in the iniquity which they had devised, returned with joy to Malachy and told him all things in order which had happened to him.

59. Malachy, knowing that by such an event the peace was disturbed, taking suitable opportunity was at pains in his own person to restore peace once more between them, and to confirm it when restored by the giving and receiving of security and an oath on both sides. But those who before had suffered from the violation of peace, mindful of the injury, and ignoring the agreement and the command of Malachy, took in hand to make reprisals. And all coming together, they set out to take their enemies unprepared and to return upon their own head the evil which they had thought to do to them. ${ }^{4}$ And when they had very easily forded a great river which lay between them, they were stopped by a rivulet to which they came, not far from it. For indeed now it was not a rivulet, but appeared clearly to be a huge river, denying passage in every part of it to those who desired to cross it. All wondered that it was now so great, knowing how small it had been before, and they said among themselves, "What has caused this inundation? The air is clear, there are no rains, and we do not remember that there have been any lately; and even if there had been much rain, which of us remembers that, to however great a flood it swelled, it ever before 
covered the land, spreading over sown ground and meadow? This is the finger of God, ${ }^{1}$ and the Lord is hedging up our zeajs, ${ }^{2}$ on account of Malachy, His saint, whose corenant we have transyressed ${ }^{3}$ and disobeyed his commandment." 4 So these also, without accomplishing their purpose, returned to their own territory, likewise confounded. The report was spread throughout all the rogion; ${ }^{5}$ and they blessed Crod, who took the wise in their oan craftiness, ${ }^{6}$ and cutting off the horns of the aricked, ${ }^{7}$ exalted the horn of His anointed. ${ }^{8}$

6o. One of the nobles hostile to the $\mathrm{king}^{9}$ was reconciled by means of Malachy. For he did not trust the king sufficiently to make peace with him except by the mediation of Malachy, or of one for whom the king had equal reverence. His distrust was not unfounded, as afterwards appeared. For when he had become careless, and was no longer taking precautions, the king captured him and put him in bonds, more truly himself captured by ancient hate. IIis own friends demanded him by the hand of the mediator; ${ }^{10}$ for neither did they

1 Exod. viii. 19.

2 Hos. ii. 6.

3 Josh. vii. 15, etc.

1 In Serm. ii. \$ 2 , where this story is again briefly told, the miracle is more directly ascribed to Malachy, and the stream is said to have swelled suddenly.

5 Cp. Luke iv. 14, etc.

"Job v. I3, combined with I Cor. iii. 19.

7 Ps. lxxv. Io.

8 I Sam. ii. Io.

9 Prolably Turlough O'Conor, who is said by the annalists to have imprisoned illegally several persons of high position, viz. (I) his own son Rory O'Conor, together with Domell O'Flaherty and Cathal O'Conor, in I I 43, (2) Murrough Ua Maelsechlainn, king of Meath, in II 43, and (3) Teague O'Brien, in I I48. Release was obtained, in the first instance, in IIft hy the clergy of Ireland and the "coarb of Patick," who fasted at Kathbrennan. The coarl, may have been Malachy. In the second instance, it was secured through the influence of certain "sureties" ; and in the third, "at the intercession of the lishops of Ireland with the coarb of P'atrick, Mael Maedoc Ua Murgair" (A.F.M., A.T.). The Annals, however, know nothing of the blinding of O'Conor. The incident in the text is mentioned in Serm. ii. $\S 2$.

10 Gal iii. 19. 
expect anything but his death. What should Malachy do? There was nothing to be done except to recur to that one accustomed refuge of his. Gathering an exceeding mighty army, a great crowd of his own disciples, he went to the king, and demanded him who was bound; he was refused. But Malachy said, "You act unrighteously against the Lord, and against me, and against yourself, transgressing the corenant; if you disregard it, yet shall not $I . A$ man has entrusted himself to my guarantee; if he should die, I have betrayed him. I am guilty of his blood. Why has it seemed good to you to make me a traitor, yourself a transgressor? Know that $I$ will eat nothing unti ${ }^{2}$ he is liberated ; no, nor these either." ${ }^{3}$ Having said this he entered the church. He called upon Almighty (iod with anxious groanings, his own and those of his disciples, that He would deign to deliver out of the hand of the transgressor and cruel man ${ }^{4}$ him who was unjustly sentenced. And that day and the following night they persisted in fasting and prayer. Word was brought to the king of that which was being done; and his heart zeas the more hardened ${ }^{5}$ by that by which it ought to have been softened. The carnal man took to flight, fearing lest if he remained near at hand he might not be able to withstand the power of prayer; as though, forsooth, if he was hidden it could not find him, nor would penetrate to a remote place. Do you put bounds, wretched man, to the prayers of saints? ${ }^{\circ}$ Is prayer an arrow that has been shot, that you may flee from the face of the boze? 7 Whither wilt thou go from the Spirit

1 Josh. vii. 15, etc.

2 Acts xxiii. It.

"An example of the well-known Irish custom of "fasting on" a person with a view to his discomfiture (cp). p. 106, n. 9).
'Ps. Ixxi. 4 (inexact quotation).
'Rev. v. $S$.
5 Exod. viii. 19.
7 Isa. xxi. $15(\mathrm{rr} \cdot)$. 
of God, who carries it, or whither wilt thou flce from His presence? ${ }^{1}$ At last Malachy pursues the fugitive, he finds him who lies hidden. "You shall be blind and not secing," that you may see better, and may understand that it is hard for you to kick against the pricks. ${ }^{3}$ Nay, perceive even now that shurp arrozes of the mighty ${ }^{4}$ have come to you, which, although they have rebounded from your heart, because it is of stone, have not rebounded from your eyes. Would that even through the windows of the eyes they might reach to the heart, and trouble give understanding 5 to blindness." It could be seen that Saul again was led by the hand "and brought to Ananias, a wolf to a sheep, that he might disgorge his prey. He disgorged it and received sight, ${ }^{7}$ for to such a degree was Malachy like a sheep, if, for example, it were to take pity even on the wolf. Note carefully from this, reader, with whom Malachy had his dwelling, what sort of princes they were, what sort of peoples. How is it that he also was not a brother to dragons, and a companion io ozols? ${ }^{8}$ And therefore the Lord gave him power to tread upon serpents and scorpions," to bind their kings zevith chains and their nobles with fetters of iron. ${ }^{10}$ Hear now what follows.

6r (34). He to whom Malachy had yielded the possessions of the monastery of Bangor, ${ }^{11}$ ungrateful for the benefit, from that time forward behaved himself always most arrogantly against him and his followers, hostile to them in all things, plotting everywhere, and disparaging his deeds. But not without punishment. He had an only son, who, imitating his father and daring himself to act in opposition to Malachy, died the same year. And

\footnotetext{
1 Ps. cxxxix. 7.

4 P's. cxx. 4.

2 Acts xiii. I I.

5 Isa. xxviii. I9.

7 Actsix. 18.

9 Luke x. I9 (quotation not exact).

11 See $\$$ I 3 .

3 Acts xxvi. 14.

6 Acts ix. $S$.

8 Joh xxx. 29

10 Ps. cxlix.
} 
thus he died. It seemed good to Malachy that a stone oratory should be erected at Bangor like those which he had seen constructed in other regions. ${ }^{1}$ And when he began to lay the foundations the natives wondered, because in that land no such buildings were yet to be found. ${ }^{2}$ But that worthless fellow, presumptuous and arrogant as he was, not only wondered but was indignant. And from that indignation he conceived grief and brought forth iniquity. ${ }^{3}$ And he became a talebearer among the peoples, ${ }^{4}$ now disparaging secretly, ${ }^{5}$ now speaking evil openly; drawing attention to Malachy's frivolity, shuddering at the novelty, exaggerating the expense. With such poisonous words as these he was urging and inducing many to put a stop to it: "Follow me, and what ought not to be done by any but ourselves let us not permit to be done against our will." Then with many whom he was able to persuade-himself the first

1 This remark proves that the building of the oratory was begun after Malachy's return from France. The same conclusion follows from the words "We are Scots, not Gauls," lower down.

2 St. Bernard is speaking, not of stone churches in gencral, as has sometimes been assumed, but of stone oratorics, which may have been unknown in "that land," $i$. $e$. the district about Bangor (see p. 32, n. 3). The innovation would naturally cause dissalisfaction among a conscrvative people. Indignation may also have been excited by the unusual size of the building ; for it was "a great oratory" $\left(\S_{3}\right)$. But on the other hand, its ormate style cannot lave contributed to the opposition which the project aroused; for it commenced when the foundations were being laicl. Indeed, however "beautiful" it may have been $\left(\$ 6_{3}\right)$, it was probably, like the churches of the Cistercians, of simple design and devoid of ornament. See St. Bernard's Afologia ad Guillelmum, $\$ 28 \mathrm{ff}$. (P.L. clxxxii. 9I4f.). The only relic of the medieval monastery of Langor is a rudely built wall, once pierced by a door and a window, now built up. It seems to be later than the twelfth century. About I 20 yards to the south-west of it is "The Abbey Church," still userl for worship. The main part of this structure dates from the seventeenth century. Inut the cure of the tower appears to be much earlier, and may be on the site of St. Malachy's oratory.

Job xv. 35 (vg.) ; P's. vii. I4 (vg.).

4 Lev. xix. 16.

5 Ps. ci. 5. 
leader in sfeech ${ }^{1}$ as well as the origin of the evil-he went down to the place, and finding the man of God accosted him: "Good sir, why have you thought good to introduce this novelty into our regions? We are Scots, not Gauls. What is this frivolity? What need was there for a work so superfluous, so proud? Where will you, a for and needy man, ${ }^{2}$ find the means to finish it? ${ }^{3}$ Who will see it finished? What sort of presumption is this, to begin, I say not what you cannot finish, but what you cannot even see finished? 'Though indeed it is the act of a maniac rather than of a presumptuous man to attempt what is beyond his measure, what exceeds his strength, what baffles his abilities. Cease, cease, desist from this madness. If not, we shall not permit it, we shall not tolerate it." This he said, proclaiming what he would do, but not considering what it was within his power to do. For somc of those on whom he counted and whom he had brought with him, when they saw the man ${ }^{4}$ changed their minds and went no more with him. ${ }^{5}$

62. And to him the holy man spoke quite freely: " Wretched man, the work which you see begun, and on which you look askance, shall undoubtedly be finished: many shall see it finished. But you, because you do not wish it, will not see it ; ${ }^{6}$ and that which you wish not shall be yours - to die: take heed that you do not die in your sins." ? So it happened: he died, and the work was finished; but he saw it not, for, as we have said already, he died the same year. Meanwhile the father, who soon heard what the holy man had foretold concerning his son, and knew that his word was quick and pozerfill, ${ }^{8}$ said, "He has slmin my son." a And by the instiga-

\footnotetext{
1 Acts xiv. I2.

3 Luke xiv. 28.

5 Cp. John vi. 66.

- John viii. 21 .
}

2 Ps. lxxiv. 2 I.

4 Tiro, i. e. Malachy.

6 Cuia non wis non widebis.
8 Itel. iv. 12.

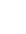
9 I Kin rs xvii. Is. 
tion of the devil he burned with such rage against him that he was not afraid, before the duke and magnates of Ulaid, to accuse of falsehood and lying him who was most truthful and a disciple and lover of the Truth; and he used violent language against him, calling him an ape. ${ }^{1}$ And Malachy, who had been taught not to render railing for raiting, ${ }^{2}$ a'as $\mathrm{dumb}$, and opened not his mouth ${ }^{3}$ while the zericked zeas before him. ${ }^{4}$ But the Lord was not forgetful of His word which He had spoken, Vengeance is mine, I will repay. ${ }^{5}$ The same day when the man returned home he expiated the rashness of his unbridled tongue, the avenger being the very one at whose instigation he had let it loose. The demon seized him and cast him into the fire, but he was soon pulled out by those that stood by ; yet with his body partly burnt, and deprived of reason. And while he was raving Malachy was called, and when he came he found the accursed man, his foaming mouth contorted, terrifying all things with horrible sounds and movements, his whole body writhing, and scarcely to be kept in restraint by many men. And when he prayed for his enemy the man of all perfection was heard, but only in part. For in a moment, while the saint was praying, he opened his eyes, and recovered his understanding. But an eqil spirit of the Lord ${ }^{6}$ was left to him to luffet him, ${ }^{7}$ that he might learn not to blaspheme. ${ }^{8}$ We believe that he still lives, and up to this time is expiating the great sin which he sinned against the saint; but they say that at certain times he is a lunatic. Further, the aforesaid possessions, since he could no longer hold them by reason of his helplessness and uselessness, returned in peace to the

1 Perhaps because he imitated the customs of the Gauls.

2 I l'ct. iii. 9.

I's. vxxix. I.

3 Isa. liii. 7 .

B I Sam. xvi. rf : xix. 9 (vg.).

5 Kom. xii r 9.

8 l Tim. i, 20.

72 Cor xii. 7 
place to which they had belonged. Nor did Malachy refuse them, when the prospcct of peace was held out at length after so much trouble.

63. But now our narrative must return to the work of the building which Malachy had undertaken. And though Malachy had not the means, I do not say to finish it, but to do any part of it, yet his heart trusted in the Lord. ${ }^{1}$ The Lord, in fact, provided that, though he set not his hope on treasures of money, ${ }^{2}$ money should not be lacking. For who else caused a treasure to be stored in that place, and being stored, not to be found till the time and work of Malachy? The servant of God found in God's purse what was not in his own. Deservedly, indeed. For what more just than that he who for God's sake possessed nothing should enter into partnership with God, and that they should both hate one purse. ${ }^{3}$ For the man who believes, the whole world is a treasury of riches; and what is it but a kind of purse of God? Indeed He says, The world is mine, and the fulmess thereof. ${ }^{4}$ Hence it was that when many pieces of silver were found Malachy did not put them back in their place, but took them out of their place; for he bade the whole gift of God to be spent on the work of God. ${ }^{5}$ He considered not his own necessities nor those of his companions, but cast his thought upon the Lord, ${ }^{\circ}$ to whom he did not doubt that he ouglat to resort as often as need required. And there is no doubt that that was the work of God, because Malachy had foreseen it by God's revelation. He had first consulted with the brothers concerning that work; and many on account

1 Susanna, 35 .

3 Prov. i. 1 i.

5 Malachy disposed of the treasure accoreling to his will. That fact, together with his relation to the lrothers, revealed hy the next few sentences, makes it exceedingly probable that he was still their abbot.
2 Ecclus. xxxi. $S$ (vg.: with variant).

4 Ps. 1. 12.

6 P's. Iv. 23 (vg.). 
of their lack of means were unwilling to assent to it. Anxious therefore and doubtful what he should do, he began to inquire earnestly in prayer what was the will of God. And one day coming back from a journey, ${ }^{1}$ when he drew near to the place he viewed it some way off; and lo, there appeared a great oratory, of stone and very beautiful. And paying careful attention to its position, form and construction, he took up the work with confidence, having first however related the vision to a few of the elder brothers. Indeed so carefully did he adhere to all his attentive observations regarding place and manner and quality that when the work was finished that which was made appeared closely similar to that which he had seen, as if he also as well as Moses had heard the saying, Look that thou make all things accordins to the fattern shered to thee in the mount. ${ }^{2}$ By the same kind of vision there was shown to him before it was built, not only the oratory, but also the whole monastery, which is situated at Saul. ${ }^{3}$

6. (35). As he was passing through a certain city and a great multitude was running together to him, by chance he saw a young man among the rest eager to see him. He had climbed up on a stone, and standing on tip-toes, with outstretched neck, contemplating him with eyes and mind, showed himself to him as a kind of new

1 Bangor was apparently his headquarters.

2 IIeb. viii. 5 .

3 Jocelin, writing towards the end of the twelfth century, declares that St. P'atrick founded a monastery at Saul (I Iila S. Palricii, cap. 32). But, apparently, neither in the Annals nor in any other authority earlier than Jocelin, is mention made of a monastery there before St. Malachy's time. The text seems to imply that there were no monastic buildings on the site when he founded (or re-founded) it. Malachy placerl in his new monastery a convent of regular canons of St. Augustine $(A . U$. I I 70$)$; but it never became an important establishment, though it was still in existence in the sixtcenth century. See Kieeves, pp. 40, 220 ff.

${ }^{4}$ This and the next story $(\$ 65)$ illustrate Malachy's power of reading the hearts of men. 
Zacchaeus. ${ }^{1}$ And it was not hid from Malachy (for the Holy Spirit revealed it) that he had truly come in the spirit and power of Zacchaeus. ${ }^{2}$ He took no notice, however, at the time, and passed on in silence. But in the hospice that night he told the brothers how he had seen him and what he had foreseen concerning him. But on the third day behold he came with a certain nobleman, his lord, who disclosed the wish and desire of the young man, and asked that he would deign to receive him on his commendation, and have him henceforth among his companions. And Malachy recognizing him said, "There is no need that man should commend him whom already God has commended. ${ }^{3}$ And taking him by the hand he delivered him over to our abbot Congan ${ }^{4}$ and he to the brothers. But that young man -still living if I mistake not--the first lay conversus of the monastery of the Suir, ${ }^{5}$ has testimony from all that he lives a holy life among the brothers, according to the Cistercian Order. And the disciples recognized also in this incident that Malachy had the sfirit of frophecr, ${ }^{6}$ and not in this only, but in that which we shall add.

65. When he was offering the sacraments, ${ }^{7}$ and the deacon had approached him to do somcthing belonging to his office, the priest beholding him groaned because he had perceived that something was hidden in him that was not meet. When the sacrifice was over, having been

1 Luke xix. I-4.

32 Cor. x. 18.

5 Suriensis monasterii. The monastery of Inislomnaght, close to the River Suir, a mile or two to the west of Clonmel, co. Tipperary, is commonly known as De Surio. The present passage seems to show that it was founded before i i. $S$. For information alout it see an article by the late Dr. Bagwell, in I.R.A.A.I. xxxix. 267 f. and Janauschek, Oris. Cist. p. I $3 \mathbf{I}$. 'This incident must have been considerably later than the foundation of Mellifont (see p. 75, n. 4). It may therefore be dated between I I 43 and I I 47 .

"Rev. xix. Io.

7 This word is constantly used in the phural of the Eucharist, each of the elements being regarded as a "sacrament." 
probed privately concerning his conscience he confessed and denied not ${ }^{1}$ that he had been mocked ${ }^{2}$ in a dream that night. And Malachy enjoined penance upon him and said, "It was your duty not to have ministered to-day, but reverently to withdraw from sacred things and to show respect to so great and divine mysteries, that purified by this humiliation you might in future minister more worthily."

Likewise on another occasion, ${ }^{3}$ when he was sacrificing and praying at the hour of sacrifice with his accustomed sanctity and purity of heart, the deacon standing by him, a dove was seen to enter through the window in great glory. And with that glory the priest was completely flooded, and the whole of the gloomy basilica became suffused with light. But the dove, after Hitting about for a while, at length settlect down on the cross before the face of the priest. The deacon wis amazed; and trembling on account of the novelty botb of the light and of the bird, for that is a rare bird in the land, fell upon his face, and palpitating, scarcely dared to rise even when the necessity of his office required it. After Mass Malachy spoke to him privately and bade him, as he valued his life, on no account to divulge the mystery which he had seen, as long as he himself was alive.

Once, when he was at Armagh with one of his fellowbishops, he rose in the night and began to go round the memorials of the saints, of which there are many in the cemetery of St. l'atrick, ${ }^{4}$ with prayer. And lo, they saw one of the altars suddenly take fire. For both saw this

1 John i. 20.

2 Gen. xxxix. 17.

3 This story is suggested by the last because the incident occurrod during the celeloration of Mass.

${ }^{4}$ Evidently the cemetery in which, according to local traclition, St. I'atrick was buried (see \$19). It was probably the Iictat Martair, the site of St. Patrick's eartier settlement at Amagh (keeves, Churches, p. $5 ;$ K.I.A. xviii. 660). It seems to be hinted that St. Malachy received a revelation of the position of his grave. 
great vision, and both wondered. And Malachy, understanding that it was a sign of the great merit of him, or those, whose bodies rested under that altar, ran and plunged into the midst of the flames with outstretched arms and embracel the sacred altar. What he did there, or what he perceived, none knows; but that from that fire he went forth ablaze more than his wont with heavenly fire, I suppose there is none of the brothers who were with him then that does not know.

66. These things have been mentioned, a few out of many, but many for this time. *For these are not times of signs, as it is written, $V_{e}$ see not signs; there is no more any prophet." Whence it appears sufficiently how great in merits was my Malachy, who was so rich in signs, rare as they now are. For in what kind of ancient miracles 2 was not Malachy conspicuous? If we consider well those fow that have been mentioned, he lacked not prophecy, ${ }^{3}$ nor revelation, ${ }^{4}$ nor vengeance upon the impious, ${ }^{5}$ nor the srace of healinss, ${ }^{6}$ nor transformation of minds, ${ }^{7}$ nor lastly raising the dead. ${ }^{8}$ By all these things God was blessed who so loved and adorned him, who also magnified him before kings," and gave him the crozen of $y / m y{ }^{10}$ That he was loved is proved in his merits, that he was adorned, in his signs, that he was magnified, in his vengeance on enemies, that he had glory, in recompense of rewards. You have in Malachy, diligent reader, something to wonder at, you have also something to imitate. Now carefully note what you may hope for as the result of these things. For the end of these things is a precious diath."

1 I's. lxxiv. 9.

2 Secret of Mass for Krings, etc.

3 A fresh classification of Malachy's miracles. For prophecy sce $\$ \$ 36,4 \$, 52,57,62,64 \mathrm{f}$.

5 \$\$2 f., $4 \$, 57,60,62$.

6 I Cor. xii. 9 (vg.).-\$\$ I 4, 1.5, 40, 45-47, 49-52, 60, 62.

$=\$ 326,54,57,6 \mathrm{r}$. \$ 53 . 10 i Pet. v. 4 .

11 Kon. vi. 21 , combined with l's. cxvi. 15. 


\section{CHAPTER VIII}

Departure from Treland. Death and Burial at Claireaux.

67 (30). Being asked once, in what place, if a choice were given him, he would prefer to spend his last day-for on this subject the brothers used to ask one another what place each would select for himself-he hesitated, and made no reply. But when they insisted, he said, "If I take my departure hence ${ }^{1}$ I shall do so nowhere more gladly than whence I may rise together with our Apostle" 2 -he referred to St. Patrick; "but if it behoves me to make a pilgrimage, and if God so permits, I have selected Clairvaux." When asked also about the time, [he named in reply] the festival of all the dead. ${ }^{3}$ If it is regarded as a mere wish, it w.ls fulfilled, if as a prophecy, not a jot passed from it. ${ }^{4}$ As ave have heard so have we sien ${ }^{5}$ alike concerning plice and day. Let us relate brielly in what order and by what occasion it came to pass. Malachy took it amiss that Ireland was still without a pall; for he was zealous for the sacraments, and would not that his nation should be wholly deprived of any one of them. ${ }^{6}$ And remembering that it had been promised to him by Pope Innocent, ${ }^{7}$ he was the more sad that while he was still alive it had not been sent for. And taking advantage of the fact that l'ope Eugenius ${ }^{8}$ held the chief rule and was reported to

1 T. e. "II I die in Ireland." $\quad 2$ In Armagh. See $\$ \$ 19,65$.

3 All Souls' Day, November 2. 'Matt. v. IS. ${ }^{5}$ Ps. xlviii. 8.

${ }^{6}$ Note that the pall is called a sacrament. ${ }^{7}$ See $\$ 38$.

8 Bernard Paganelli, a monk of Clairvaux, was sent to Rome by S. Bernard at the request of Innocent II. and was appointed 
have gone at that time to France, ${ }^{1}$ he rejoiced that he had found opportunity for claiming it. He took for granted that, the Pope being such a man as he was, and having been promoted from such a religious profession -and the more because he had been a special son of his own Clairvaux-he need not fear that he should have any difficulty with him. Therefore the bishops I4 4 , were summoned ; a council assembled. ${ }^{2}$ Matters
May (?) which were of immediate importance at the time were discussed for three days, and on the fourth the scheme of obtaining the pall was broached. Assent was given, but on condition that it should be obtained by another. However, since the journey was a comparatively short one, and on that account the pilgrimage seemed more easy to be endured, none presumed to oppose his counsel and will. And when the council was dissolved Malachy siarted on his way. ${ }^{3}$ Such brothers as had come together followed him to the shore; but not many, for he doubtless

abbut of the monastery of St. Anastasius. On the death of Lucius II. he was elected l'ope, February 15, I I44, and assumed the title of Eugenius III. (II. K. Mann, Lizes of the Popes, ix. $13 \mathrm{Iff}$ )

1 Eugenius left Viterbo at the beginning of 1477 . He was at Lyons in March, and at Troyes on April 10 (Jaffé, p. 624 ff.; Mamn, ix. $\left.I S_{5}\right)$.

2 In accordance with the instructions of Innocent II. $\left(\begin{array}{l}\$ \\ \$\end{array}\right)$ : "A Synod was convened at Inis Patraic by Mael Maedoc, coarb of latrick, at which were present fifteen bishops and two bundred priests, to establish rules and morals for all, both laity and clergy ; and Mael Maedoc Ua Morgair, by the advice of the Synod, went a second lime to Kome (sic) to confer with the comarb of l'eter" (A.F.M. II 4 ). Inispatrick is a small island off Skerries, co. Dublin. For the date see K.A.I. xxxv. $249 \mathrm{f}$. In the same year Malachy had consecrated the monastery of Knock (A.F.M. See p. 67, n. 3 ).

3 St. Bernard seems to have thought that St. Malachy set sail immediately after the Synod, and from a port not far from the place where it met. But this is impossible, for one day's sail brouglht him to Scotland (\$68). Ife seens to have embarked at Bangor, which is about a hundred miles north of Inispatrick. 
restrained them. One of them, Catholicus by name, with tearful voice and face, said to him, "Alas! you are going away; and in how great, almost daily, trouble you leave me you are not ignorant, and yet you do not, of your pity, give me help. If I deserve to suffer, what sin have the brothers committed that they are scarcely allowed to have any day or night free from the labour of caring for and guarding me?" By these words and tears of his son (for he wept) the father's heart an'ts troubled, ${ }^{1}$ and he embraced him with caresses, and making the sign of the cross on his breast said, "Be assured that you will have no such suffering till I return." Now he was an epileptic, and fell often; insomuch that at times he suffered not once but many times a day. He had been a victim to this horrible disease for six years; but at the word of Malachy he made a perfect recovery. From that hour he has suffered no such thing; no such thing, as we believe, will he suffer henceforth, for henceforth Malachy will not return.

68. When he was just about to embark there came unto him two of those who clave unto him ${ }^{2}$ more closely, boldly desiring a certain thing of him. And he said to them, "What would ye?" 3 And they answered, "Wc will not say, except you promise that you will give it." He pledged himself. And they said, "We would have you certainly promise of your condescension, that you will return in good health to Ireland." All the others also insisted upon it. Then he deliberated for a while, repenting at first that he had bound himself, and not finding any way of escape. He was straitened on every side, ${ }^{4}$ while no way of safety presented itself from both dangers-of forfeiting his wish and of breaking his promise. It seemed at length thai he should rather

1 Cp. Lam. ii. II. 2 kuth i. It.

"Matt. xx. 20, combined with Mark x. 35, 36. 4 Susanna, 22. 
choose that which influenced him more strongly at the moment, and leave the rest to higher guidance. $\mathrm{He}$ assented, sadly it is true; but he was more unwilling that they should be made sad; and pledging himself as they wished, he went on board the ship. And when they had completed nearly half the royage suddenly a contrary wind drove the ship back and brought it to the land of Ireland again. Leaving the ship he passed the night in the port itself in one of his churches. And he joyfully gave thanks for the resourcefulness of the divine providence, by which it came about that he had now satisfied his promise. But in the morning he went $\mathrm{cn}$ board, and the same day, after a prosperous crossing, came into Scotland. On the third day ${ }^{1}$ he reached a place which is called Viride Stagnum ; ${ }^{2}$ which he had caused to be prepared that he might found an abbey there. And leaving there some of his sons, our brothers, as a convent of monks and abbot ${ }^{3}$ (for he had brought them with him for that purpose) he bade them farewell and set out.

69. And as he passed on, King David met him, by whom he was received with joy and was detained as his guest for some days." And having done many things pleasing to God he resumed the journey that he had begun. And passing through Scotland, at the very border of England he went aside to the Church of

1 'That is, the first day after his landing in Scotland.

2 The Green Lake. It is now Soulseat, about eight miles from Cairngarroch. At this place Fergus, lord of Galloway (p. 76, n. 4), founded a famous monastery of I'remonstratensian canons (Grub), Eccl. Hist. of Siotland, i. 269), which must not be confuscd with Malachy's more humble community.

3 The abbot was Michael, who had belonged to the community at Bangor (\$ I 5). As this new community is called "a convent of monks" we may infer that it was of the Cistercian Order.

$\checkmark$ Note the leisureliness of the journey in its earlier stages. Later on Malachy encountered difficulties, which no doubt involved further delay (Serin. i. \$ I). 
Gisburn, where there dwell religious men leading a canonical life, ${ }^{1}$ familiar to him of old for their religious conversation and honourable character. At that place a woman was brought to him, suffering from a disease horrible to see, which is commonly called cancer; and he healed her. For when water which he blessed was sprinkled on the sores she ceased to feel pain. On the next day scarcely a sore was to be seen.

Departing thence he came to the sea, but was refused passage. The reason, if I am not mistaken, was that some difference bad arisen between the chief pontiff and the king of England: for the king suspected in that good man I know not what evil, if he should cross the sea $;^{2}$ for neither did he allow other bishops to cross. ${ }^{3}$ 'That obstacle, though contrary to the will of Malachy, was not contrary to the object of his wish. He grieved that the attaimment of his desire should be postponed, not knowing that by this it would be the rather fulfilled.

1 Gisburn is a village in the West Riding of Vorkshire on the river Ribble, not far from the border of Lancashire. It is clear that on this occasion Malachy followed the line of Watling Street, which ran througl, Ribchester, on the Ribble, about fourteen miles from Gisburn. Ifis road probalsly passed within three miles of that place between Settle and Chethurn. He seems to have avoided entering England as long as possible-supposing no doubt, and with good reason, that he was safer in the dominions of David than in those of Stephen. For details of the journey see R.I.A. xxxv. $239 \mathrm{ff}$, 2.49. The monastery of Gisburn, of which the ruins remain to the south of the parish church, was founcled for Augustinian canone, in 1129, by Robert de Brus (Dugdale, vi. I, 265 ff.).

2 Malachy was probably suspected (not without cause) of being an emissary of the supporters of the Empress Matilda. IIe had just spent some days with David I., and with him and his stepson Waltheof he was on terms of intimate friendship $(\$ \$ 36,40)$. King David invaded England in the following year.

3 The reference is apparently to King Stephen's attempt to prevent Theobald of Canterbury and other hishops from attending the Council of Rheims in Narch I 448 . But Malachy does not seem to have been summoned to the Council, and he did not reach the Chamnel till longr after it was over (see next note). 
For if he had immediately passed over the sea he would have been obliged to pass by Clairvaux in order to follow the chief Pontiff. For by that time he had left it and was at or near Rome. ${ }^{1}$ But now through this delay it was brought about that he crossed later, and so, as was fitting, he came to the place of his most holy deatin, and at the hour of its approach.

$70(37)$. And he was received by us, though he came from the west, as the true day-string ${ }^{2}$ from $11+8$, on high visiting $"{ }^{3}{ }^{3} \quad 0$, how greatly did that Oct. 13 radiant sun fill our Clairsaux with added
or 14 glory! How pleasant was the festal day that dawned upon us at his coming! This zias the day which the Lord had made, we rejoiced and aere glad in it. ${ }^{4}$ is for me, with what rapid and bounding step, though trembling and weak, ${ }^{5}$ did I soom $m$ nin to meet him! With what joy I kissed lim! With what joyful arms I embraced ${ }^{6}$ this grace sent to me from heaven! With what eager face and mind, my father, $I$ bronght thee into my mother's house and into the chamber of her that conceived me!? What festive days I spent with thee then, though few! But how did he in his turn greet us? In truth our pilgrim showed himself cheerful

1 Eurenius left Clairvaux on April 27, and Lausanne on May 20 (faffé, p. 63.1). At this rate he might have been expected to reach kome ly the end of July. About that time, therefore, we may conjecture that Malachy was on the coast of Kent. Actually, the I'ope was not near Rome till he reached Viterbo on November $3^{\circ}$ (ilid. 636). St. Bernard, therefore, when he wrote this passige, was ignorant of his movements for a considerable time before Malachy's death.

2 Oriens: literally, "cast." 3 ruke i. $7 \mathrm{~S}$.

4 P's. cxviii. 2.4.

5 St. Bernard's lifelong and ever-increasing frailty is constantly alluded to by his biographers. It was largely due to his extreme austerity. In this incident we have an example of the way in which, on many occasions, the strength of his mind conquererl the weakness of his borly ( $l . l$. v. 4).
${ }^{6}$ Gen. xxix. 13.
7 Cant. iii. 4 . 
and kindly to all, to all incredibly gracious. How good and how pleasant ${ }^{1}$ a part he played among us as our guest, whom, forsooth, he had come from the uttermost parts of the earth to see, not that he should hear, but that he should show us, a Solomon! In fact we heard his zeisdom, ${ }^{2}$ we had his presence, and we have it still. Already four or five days of this our festival had passed, when lo, on the feast day of Blessed Luke the I1 4 S,
Oct. IS Evangelist, ${ }^{3}$ when he had celebrated Mass in the convent ${ }^{4}$ with that holy devotion of his, he was taken with a fever and lay down in his bed: and all of us were [siek] with him. The end of our mirth is sorrow, ${ }^{5}$ but moderate sorrow, because for a time the fever seemed to be slight. You should see the brothers running about, eager to give, or to receive. To whom was it not sweet to see him? To whom was it not sweeter to minister to him? Both were pleasant and both salutary. It was an act of kindness to do him service, and it was repaid also to each one of them, by the gift of grace. All assisted, all were busied with much serving, ${ }^{6}$ searching for medicines, applying poultices, urging him often to eat. But he said to them, "These things are without avail, yet for love of you I do what ever you bid me." For he knew that the time of his departure was at hand.?

\section{I's. cxxxiii. I. 2 Matt. xii. 42 ; Luke xi. $3 \mathbf{I}$.}

3 October IS. Malachy had therefore reached Clairvaux on October I 3 or 14. In the interval he met St. Gilbert of Sempringham and presented him with a pastoral staff (1)ugdale, vi. 2, p, xii.). In France Nalachy travelled alone-having been parled from his eompanions in England-and probably on horselsack $\left(\$ 3^{6}\right)$. Ile may, therefore, have left England about September $3^{\text {o, and }}$ traversed the 270 miles from Wissant to Clairvanx hy Octolere 14. Ile apparently intended to start for kome on St. Luke's Day (Serm. i. \$1).

4 That is, in the presence of the community.

5 Prov. xiv. I3 (inexact quotation).

- Luke x. 40.

7 Cp. 2 Tim. iv. 6, in which the phraseolngy of the vis. differs entirely from that of the text. 
7I. And when the brothers who had come with him 1 urged him more boldly, saying that it behoved him not to despair of life, for that no signs of death appeared in him," he said, "It behoves Malachy to leave the body this year." 3 And he added, "See, the day is drawing near which, as you very well know, I have always desired to be the day of my dissolution. ${ }^{4}$ I know zehom I have belieited and am persuaded; ${ }^{5}$ I shall not be disappointed of the rest of my desire, ${ }^{6}$ since I already have part of it. He who by his mercy has led me to the place which I sought, will not deny me the time for which I wished no less. As regards this mean body, here is my rest ${ }^{7}$ as regards my soul, the Lord will provide, who sareth them that put theirtrust in Him. ${ }^{8}$ And there is no small hope lail up for me at that day ${ }^{9}$ in which so great benefits are bestowed by the living on the dead. ${ }^{10}$ Not far away was that day when he spoke thus. Meanwhile be ordered that he should be anointed with the sacred oil. When the convent of brothers was going out that it might be done solemnly, ${ }^{11}$ he would not permit them to come up to him; he went down to them. For he was lying in the balcony ${ }^{12}$ of the upper house. He was anointed; and when he had received the viaticum, he commended himself to the prayers of the brothers, and the brothers to God, ${ }^{13}$ and went back to bed. He went down from

1 Not strictly accurate. Nalachy reached Clairvaux before his companions. See p. 123, 1. 3 .

2 The physicians said the same (S rm. i. \$2).

3 This saying is quoted in a slightly different form in Serm. i. \$ 2 .

42 Tim. iv. 6.

5 Tim. i. I 2.

${ }^{6}$ I's. Ixxviii. 3o ( $\left.\mathrm{vg}.\right)$.

8 Ps. xvii. 7.

7 Ps. cxxxii. I4 (inexact quotation).

10 All Souls' Day.

11 For the Cistercian method of administering unction see $U$ sus antiquiones ordinis (isterciensis, iii. 94 (I'.L. clxvi. I471).

12 Solario.

${ }^{13} \mathrm{Cp}$. Letter iv. $\$ 2$, where it is added that he commended the Irish lirothers to the care of St. Bernard. 
the high balcony ${ }^{1}$ on his feet, and again, as if that were not enough, he went up on his feet; yet he said that death zeas at the doors. ${ }^{2}$ Who should believe that this man was dying? Himself alone and God could know it. His face did not seem to have become pallid or wasted. His brow was not wrinkled, his eyes were not sunken, his nostrils were not thin, his lips were not contracted, his teeth were not brown, his neck was not gaunt and lean, his shoulders were not bowed, the flesh on the rest of his body had not failed. Such was the grace of his body, and such the glory of his countenance zohich acas not to be done areay, ${ }^{3}$ even in death. As he appeared in life so was he also in death, more like to one alive.

$72\left(3^{8}\right)$. Hitherto our story has run a rapid course; but now it stays because Malachy has finished his course. ${ }^{4}$ $\mathrm{He}$ is still, and with him we are still. Moreover, who would willingly hasten to [tell of] death? Especially thy death, holy father, who could describe it? Who would wish to hear the story? Yet we loved in life, in death zee shall not be divided. ${ }^{5}$ Brothers, let us not forsake in death him with whom we companied in life. From further Scotland ${ }^{6}$ he ran hither to death; let us also so and die roith him. ${ }^{7}$ I must, I must tell that which of necessity I saw. The celebration, everywhere renowned, of All Saints ${ }^{8}$ comes, and according to the ancient saying, Mhisic in mourning is an unseasonable discourse. ${ }^{9}$ We come, we sing, even against our will. WC weep while we sing and we sing while we weep.

1 Solio.

3 Cor. iii. 7. Tim. iv. 7 .
52 Sam. i. 23 (inaceurate quotation). - Contrast St. Pernarl's lament for his brother Gerard (Cant. xxvi. 4): "We loved in life, how have we leen divided in death? Host bitter separation!"

6 Ireland.

8 November I. For the translation of relics which took place, apparently on that day, see Serm. i. 2.

9 Ecelus. xxii. 6. 
Malachy, though he sings not, yet does not lament. For why should he lament, who is drawing near to joy? For ws who remain, ${ }^{1}$ mourning remains. Malachy alone keeps festival. For what he cannot do with his body he does with his mind, as it is written, The thought of man shall confess to thee, and the residue of thought shall leces the der' of festival to thee. ${ }^{2}$ When the instrument of the body fails him, and the organ of the mouth is silent, and the office of the voice ceases, it remains that with songs in his heart he keeps festival. Why should not the saint keep festival, who is being brought to the festival of the saints ? ${ }^{3}$ He presents to them what will soon be due to himself. Yet a little while ${ }^{4}$ and he will be one of them.

73. Towards the dusk of night, when now somehow the celebration of the day had been finished by us, Malachy had drawn near, not to dusk but to dawn. Was it not dawn to him ${ }^{5}$ for whom the night is far spent and the day is at hand? ${ }^{6}$ So, the fever increasing, a burning sweat from within him began to break out over his whole body, that, as it were going through fire and through water, he might be brousht into a vialthy flace. ${ }^{7}$ Now his life was despaired of, now each one condemned his own judgement, now none doubted that Malachy's word ${ }^{8}$ was prevailing. We were called; we came. And lifting up his cyes on those who stood round him, he said, "With desire I hate desired to eat this fassocer with you $;{ }^{9} \mathbf{I}$

1 I Thess. iv. I7.

2 I's. Ixxvi. Io (vg.).

3 Sanctortm . . sollemnitatem. Not the Festival of All Saints, for that had already come, but, as the next sentence shows, the festival assembly of the saints in heaven. Compare Ps. lxxiv. 4, where congregations represents solemnitatis in the Vulgate.

4 John xiv. 19, etc.

5 Cp. Cant. xxvi. II, "For thee, brother, even at mirlnight the day dawned."

"Kom. xiii. 12.

7 I's. lxvi. I2.

8 Sec $\$ 71$

9 Luke xxii. 51.-This saying is quoted in Serm. i. $\S 5$. 
give thanks to the divine compassion, I have not been disatpointed of my desire." 1 Do you see the man free from care in death, and, not yet dead, already certain of life? No wonder. Seeing that the night was come to which he had looked forward, and that in it the day was dawning for him, so to speak triumphing over the night, he seemed to scoff at the darkness and as it were to cry, "I shall not say, surely the darkness shall cover" me, because this night shall be light about me in my pleasure." 2 And tenderly consoling us he said, "Take care of me; if it be allowed me I shall not forget you. And it shall be allowed. I have believed in God, ${ }^{3}$ and all things are possible to him that helieveth." I have loved God; I have loved you, and charity never faileth." 5 And looking up to heaten" he said, "O God, keep them in Thy name: 7 and not these only but all them also zoho through my arorl ${ }^{8}$ and ministry have given themselves to thy service." Then, laying his hands on each one severally and blessing all, ${ }^{9}$ he bade them go to rest, because his hour weras not yet come. ${ }^{10}$

74. We went. We returned about midnight, for at that hour it was announced that the light shincth in darkness." The house filled, the whole community was present, many abbots also who had assembled. With tosalms and hymns and spiritual songs ${ }^{12}$ we followed our friend as he returned to his own country. ${ }^{13}$ In the fifty-

1 l's. lxxviii. 30 (vg.).

2 I's. cxxxix. I I (vig.).-Cp. Cant. xxvi. I I : "Alrealy for thee, my brother, even at midnight the day was dawning, and the night was shining as the day; straight way that night zots light about thec in thy pleasure. I was summoned to that miracle, to see a man exulting in death and mocking death."
3 John xiv. I.
6 Nlark vii. 34 .
" Mark ix. 23 .
7 John xvii. II.

${ }^{\circ}$ Cp. Praef. 2.

11 John i. 5 .

10 John vii. 30 .

12 Eph. v. I9; Col. iii. 16.

13 The meaning of the phrase is explaincel in De Cons. v. 2: "This will he a returning to our own country, when we leave the 
fourth year of his age, ${ }^{1}$ at the place and time which 1148 , he had chosen beforehand and predicted, Novem- Malachy, the bishop and legate of the holy
ber 2 $\Lambda$ postolic See, taken up ly the angels, ${ }^{2}$ as it were from our hands, happily fell asleep in the Lord. $^{3}$ And indeed he slept. His placid face was the sign of a placid departure. And verily the eyes of all aeve fixed upon him; ${ }^{4}$ but none could perceive when he departed. When dead he was thought to be alive, when alive, dead; so true was it that there was no difference which might distinguish death from life. The same vivacity of face, the same serenity, as commonly appears in one who sleeps. You might say that death robbed him of none of these things, but rather very greatly increased them. He was not changed; but he changed us all. In wondrous fashion the sorrow and groaning of all suddenly sank to rest, sadness was changed into jol, ${ }^{5}$ singing banished lamentation." He is borne forth, voices are borne to heaven, he is borne into the oratory on the shoulders of the abbots. Faith lats conquerel, ${ }^{7}$ affection triumphs, things assume their normal course. All things are carricd out in order, all proceed in the way of reason.

75. And in truth what reason is there to lament Malachy immoderately, as though his death was not

country of our bodies and reach the realm of spirits-I mean our Cod, the Mighty Spirit, the great abiling place of the spirits of the blest" (Lewis's Iranslation, slightly altered). Cp. Serm. ii., \$ 6 .

1 A.F.M. say, "after lhe lifiy-fourth year of his age." St. Bernark appears to be right. For Malachy was made bishop of Connor when he was just entering his thirtieth year (\$ I6), i.e. about his twenty-ninth birthday. A.F.11. give the date as I I2A. liut if he was over fifty-four on November 2 , I I 4 S $(\$ 75)$, his twentyninth birthday would have been before November i I 3 . If he was under fifty-four on that day it may have been in I 124 .
2 Luke xvi. 22.
3 Acts vii. 60 (vg.).
4 Luke iv. 20.
5 Esth. xiii. I7 (vg.) ; xvi. 2 I (vg.) ; cp. John xvi. 20, elc.
6 Cp. Anors viii. 10.
${ }^{7}$ I John v. 5 . 
precious, ${ }^{1}$ as though it was not rather slecp than death, as though it was not the port of death and the portal of life? ${ }^{2}$ Our friend Malachy sleepeth ${ }^{3}$; and I, must I mourn? such mourning is based on custom, not on reason. If the Lord hath given His beloved one slect, and such sleep, in which there is an heritage of the Lord, even children, and the rearard, the fruit of the reoml," which of these things seems to call for weeping? Must I weep for him who has escaped from weeping? $\mathrm{He}$ rejoices, he triumphs, he has been brought into the joy of his Lord, ${ }^{5}$ and I, must I lament for him? I desire these things for myself, I do not grudge them to him. Meanwhile the obsequies are prepared, the sacrifice is offered for him, ${ }^{6}$ all is performed according to custom with the greatest devotion. There stood some way off a boy whose arm hung by his side dead, rather burdensome to him than useful. When I discovered him I signed to him to come near, and taking his withered hand I laid it on the hand of the bishop, and it restored it to life. For in truth the grace of healings ${ }^{7}$ lived in the dead; and his hand was to the dead hand what Elisha was to the dead man. ${ }^{8}$ The boy lad come from far ${ }^{9}$ and the hand which he brought hanging down, he carried back whole to his own country. Now, all things having been duly accomplished in the very oratory of Saint Mary, Mother of God, in which he zens zeell pleased, ${ }^{10}$

1 I's. cxvi. 15 .

3 John xi. I 1 .

5 Matt. xxv. $21,23$.

6 St. Bernard himself celebrated Mass, and by divine inspiration, " when the sacrifice was finished, changel the order of the prayer and introduced the collect for the commemoration of saints who were bishops instead of that which was used for the commendation of the dead," anticipating, as we may suppose, Malachy's canonizalion. He then devoutly kissed his feet ( $I . I$ '. iv. $2 \mathrm{I})$.
7 I Cor. xii. 9 (vg.).
- Mark viii. 3 .
2 lings xiii. 21.
10 Matl. iii. I7. 
Malachy is carried to his burial ${ }^{1}$ in the eleven hundred and forty-eighth year from the Incarnation of the Lord, on the fourth of the Nones of November. ${ }^{2}$ 'Thine, good Jesus, is the deposit which has been committed to us, ${ }^{3}$ Thine is the treasure which is laid up with us. ${ }^{4}$ We keep it ${ }^{5}$ to be given bac' $\mathrm{k}$ at the time when 'Thou shalt see fit to recall it; only that he may not go forth without his comrades, but that him whom we have had as our guest we may have also as our leader, when we shall reign with 'Thee, and with him also, for ever and ever. ${ }^{6}$ AMEN.

I Malachy was buried on the north side of the Oratory, vested in St. Bernard's habit. Five years later St. Bernard was buried before the Altar of Saint Mary, clad in the habit in which Malachy died, and which he had worn ever since his death when he celebrated Mass (I.P. v. 15, 23, 24). For further particulars of St. Malacly's burial and the disposal of his relics see R.Q.H. lii. $43 \mathrm{f}$.

2 November 2. From this statement (see p. I2S, n. I) we may infer that Malachy was born in I095, before November.

32 Tim. i. I 2.

t The biographers of St. Bernard give no detailed account of any of Malachy's visits to Clairvaux. But one of them-Geoffrey, St. Bernard's secretary - wrote a prayer for the Bright Valley, in which he placed Malachy on a par with the great Cistercian, thereby revealing to us the extraordinary impression which he made on the community ( $I . P$. v. 25). I owe the following translation of it to a friend: "Grant, O Lord, thy never-failing bounty to the spiritual harvest of the Valley, which thou didst deem worthy to illumine with two stars of such surpassing brightness, so making it brighter in very truth even than in name. Do thou guard the house wherein this twofold treasure is laid up and guarded for thee. Be it also unto us according to thy word, that as thy treasure is there so may thy heart be also; there too thy grace and mercy: and may the favour of thy compassion for ever rest on all who are gathered together in the self-same place in thy Name, which is above every name, even as thou art over all, God blessed for ever.-AMEN."

52 Tim. i. I2.

6 Rev. xxii. 5 . 


\section{LETTERS OF ST. BERNARI}

To Malachy. IIft.

(Epistle 34r.)

To the venerable lord and most blessed father, Malachy, by the grace of God archbishop of the Irish, legate of the Apostolic See, Brother Bernard called to be abbot of Clairvaux, [desiring] to find grace with the Lord.

I. Amid the manifold anxieties and cares of my heart, ${ }^{2}$ by the multitude of which my soul is sore vered, ${ }^{3}$ the brothers coming from a far country' ${ }^{4}$ that they may serve the Lord, ${ }^{5}$ thy letter, and thy staff, they comfort me: ${ }^{6}$ the letter, as a proof of good will; the staff, to support my weak body; the brothers, because they serve the Lord

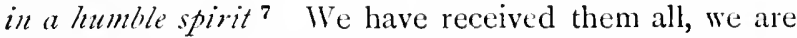
pleased with all, all alike work together for good. ${ }^{8}$ But as to the wish that you have expressed that two of the

1 When this letter was written certain brothers, sent by Malachy after his return from Rome (Oetober I 4 40), had arrived at Clairvaux, and had spent some time there (see notes 5,7 ); and the brothers left there on his return journey had had a considerable amount of instruction (n. 7). The date is therefore not earlier than II4I. But it is evidently earlier than that of Letter ii.

${ }^{2}$ Cp. IJor., Sat. i. 2. I Io. "Ps. vi. 3. "Josh. ix. 6.

"These were some of the brothers sent from Ireland (Life, \& 39).

${ }^{6}$ I's. xxiii. 4.

7 Song of Three Children, 16.-They had evidently been a good while under St. Bernard's eye.

8 Rom, viii. 28. 
brothers $^{1}$ should be sent to look out a place for you beforthand, having taken counsel with the brothers, we have not thought it meet that they should be separated one from another ${ }^{2}$ until Christ be more fully formed in them, ${ }^{3}$ until they are wholly instructed in the battles of the Lord. ${ }^{4}$ When therefore they have been taught in the school of the Holy Spirit, when they have been cudued with fouter from on high, ${ }^{5}$ then at length the sons shall return to their father that they may sing the Lord's song, not now in a strange land, ${ }^{6}$ but in their own.

2. But do you yourselves in the mean time, according to the arisdom giz'en you ${ }^{7}$ by the Lord, look out beforehand and prefare beforehand a place for them, s like the places which you have seen here, apart from the commotions of the world. For the time is at hand ${ }^{9}$ when, by the operation of the grace of God, we shall bring forth for you "li'ze men out of the old. ${ }^{10}$ Blessed be the Name of the Lord for exer, ${ }^{11}$ of wollose only gift it cometh that ${ }^{12}$ I have sons in conmon with you, whom your preaching planted and our exhortation zeatered, but God gave the increase. ${ }^{13}$ We beseech your holiness to preach the roord of the Lord $\mathbf{1 4}^{\mathbf{1 4}}$ so that you may give knozeledge of salation unto His people. ${ }^{15}$ For a double necessity is laid "pon you, ${ }^{\mathbf{1 6}}$ both from your office as legate and your duty as bishop. Finally, since in many things zere offend all, ${ }^{17}$ and, being often thrown among the men of this age, we are much besmirched with the dust of the world, I conmend myself to your prayers and to those of your companions,

1 No doubt the four brothers who bad heen left at Clairvaux (I.ifi, $\$ 39$ '.
2 Matt. $\times x v \cdot 32$.
5 luke xxiv. 49.
8 John xiv 2.
10 Cp. Kom. vi. 6; Eph. ii. 15 ; iv. 22, 24.
11 Dan. ii. 20 , elc.
$13{ }^{\prime} 1$ Cor. iii. 6.
16 I Cor. ix. 16.
3 Gal. iv. 19. $\quad$ I Sam. xxv. 28.
6 Ps. cxxxvii. 4. 72 Pet. iii. I 5.
9 Rev. i. 3 ; xxii. 10.
12 Coll. for 13 ih Sunday after !'entecost.
14 Acts xv. 36. 15 Luke i. 77 17 Jas. iii. 2. 
that in His fountain of mercy Jesus Christ, himself the fountain of pity, may deign to wash and cleanse us, who said to Peter, If I aerash thee not, thou shalt hate no part werith me. ${ }^{1}$ And, indeed, I not only earnestly entreat this of you, but also require it as in some sense the payment of a debt, since I cry to the Lord for you, if the prayer of a sinner can do anything. Farewell in the Lord.

\section{II}

To Malachy. IItr or IIf2.2

(Epistle 356.)

To Nalichy, by the grace of God bishop, legate of the Apostolic See, Brother Bernard, called to be abbot of Clairvaux, if the prayer of a simner can do anything, and if the devotion of a poor man is of any advantage.

IVe have done what your holiness commanded, not perhaps as it was worthy to be done, yet as well as was possible considering the time in which we live. So great evil every where struts about among us that it was scarcely possible to do the little that has been done. We have sent only a few grains of seed, ${ }^{3}$ as you see, to sow at least a small part of that field into which the true Isacac once went out to meditate, when Rebekalh was first brought to him by Abraham's servant, to be happily joined to

1 John xiii. $S$ (inexact quotation).

Mellifont was probably founded inumediately after the brothers mentioned in the letter reaclsed Ireland. The date is therefore in or before I I 42. They would liardly have been sent till news had reached St. Bernard that the site liad been choser: (Lett. i, \$ 2 ). Cp. p. 75 , n. 4 .

"The lirollers sent from Clairvaux "sufficient in number for an abluey " (Lifi', \$39). 
him in everlasting marriage. And the seed is not to be despised concerning which we find that word fulfilled at this time in your regions, ${ }^{2}$ Except the Lord of Sabaoth had left us a seed, we had been as Sodoma, and been made like unto Gomorrha. ${ }^{3}$, therefore, have sown, do you zirater, and God shall giv'e the increase. ${ }^{4}$ All the saints who are with you we salute through you, humbly commending ourselves to their holy prayers and yours. Farewell.

\section{III}

\section{To Malachy. I 143 or I I $44^{5}$ \\ (Epistle 357.)}

'To our most loving father and most revered lord, Malachy, by the grace of God bishop, legate of the Holy and Apostolic See, the servant of his holiness, Brother Bernard, called to be abbot of Clairvaux, health and our prayers, of whatever value they may be.

I. How szceet are thy zoords unto my taste, ${ }^{6} \mathrm{my}$ lord and father. How pleasant is the remembrance of thy

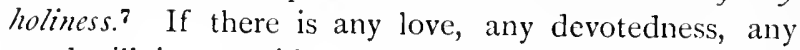
good will in us, without doubt the charity of your belovedness claims it all as its due. There is no need for a multitude of words where affection blossoms abun-

${ }^{1}$ Gen. xxiv. 63 ff. $-\mathrm{Cp}$. De Cons. ii. I3, where the same passage of Genesis is referred to. It is there ( $\$$ I 2 ) explained that the field is the world, which has been placed in charge of the Pope.

2 Printed text fatribus. I read partibus.

3 Rom. ix. 29 (inexact quotation).

4 I Cor. iii. 6.

5 Mellifont had been founded a good while before the letter was written. Christian had returned to Clairvaux; and now after further instruction he was sent back, apparently as the bearer of the letter. The house had made good progress, but the buildings were still far from complete $(\$ 2,3)$.

6 Ps. cxix. 103.

7 Ps. xxx. 4. 
dantly. For I am confident that the Spirit zehich you have from God ${ }^{1}$ bears anitness ath your spirit that ${ }^{2}$ zolut we are, ${ }^{3}$ however small it be, is yours. ${ }^{4}$ You also, most loving and most longed-for father, deliver not to forgetfulness the soul of the poor man, which cleaves to thee with the bonds of charity, and forget not the soul of thy boor man for ever. ${ }^{5}$ For $n t$ ither, as it were anew, do zee commend ourselaes unto you ${ }^{6}$ when now for a long time we glory in the Lord ${ }^{7}$ that our littleness has been worthy to find grace in the sightl of your boliness; ${ }^{8}$ but we pray that our affection, no longer new, may advance with new accessions day by day. We commend to you our sons, yea also yours, and the more earnestly because they are so far removed from us. You know that, after God, all our trust was in you, in sending them, because it seemed to us wrong not to fulfil the prayers of your holiness. See, as becomes you, that with your whole heart of love you embrace them and cherish them. In no wise for any cause let your earnest care for them grow cold, nor let that perish which thy right hand hath planted. ${ }^{9}$

2. We have now indeed learned both from your letter and from the report of our brothers ${ }^{\mathbf{1 0}}$ that the house is making good progress, [and] is being enriched both in temporal and spiritual possessions. ${ }^{11}$ Wherefore we rejoice greatly with you and give thanks with our whole heart to God and to your fatherly care. And because there is still need of great watchfulness, because the place is new, and the land unaccustomed to the monastic life, yea, without any experience of it, ree besech you in

\footnotetext{
11 Cor. ii. I 2.

3 I Cor xv. Io.

${ }^{5}$ Ps. ixxiv. 19 (rg.) ; Jer. xx. 13.

72 Cor. X.17; 1 Cor. i. 3 I.

${ }^{9}$ Ps. lxxx. I5.

10 Apparently the returned brothers mentioned below.

${ }^{11} \mathrm{Cp}$. the passage quoted $\mathrm{p} .170$.

2 Rom. viii. I6.

4 I Cor. iii. 22.

62 Cor. v. I 2.

8 I Sam. i. IS, erc.
} 
the Lord,' that you slack not your hand," but perfectly accomplish that which you have well bcgun. Concerning our brothers who have returned from that place, ${ }^{3}$ it had pleased us well if they had remaincd. But perhaps the brothers ${ }^{4}$ of your country, whose characters are less disciplined and who have lent a less ready ear to advice in those observances, which were new to then, have been in some measure the reason for their return.

3. We have sent back to you Christian, our very dear son, and yours. We have instructed him more fully, as far as we could, in the things which belong to the [Cistercian] Order, and henceforth, as we hope, he will be more careful concerning its obligations. ${ }^{5}$ Do not be surprised that we have not sent any other brothers with him ; for we did not find competent brothers who were ready to assent to our wishes, and it was not our plan to compel the unwilling. Our much-loved brother, Robert, ${ }^{6}$ assented on this occasion also to our prayers, as an obedient son. ${ }^{7}$ It will be your part to assist him that your house may now be sct forward, both in buildings and in other necessaries. This also we suggest to your fatherhood, that you persuade religious men and those who, you hope, will be useful to the monastery, to come into their Order, for this will be of the greatest advantage to

1 I Thess. iv. I. 2 Josh. x. 6.

3 The monks of Clairvaux seem to have been reluctant to undertake work elsewhere, when St. Bernard desired them to do so ( $I . I^{\prime}$. vii. $52 \mathrm{f}$.) ; and we have one instance of an abbot of a daughter house-llumbert of Igny-who resigned his office and returned to Clairvaux against St. Bernard's will (Ep. I4I).

4 l'rinted text, fratrum. Read fratres.

5 Evidently Christian did not prove a satisfactory abbot. This may in part account for the return of the monks who went with him to Ireland.

6 Of this Robert, apparently the architect of Mellifont, we know nothing; for suggestions that he should be identified with one or other of the monks of Clairvaux who bore the same name are mere gllesses.

7 I Pet. i. If (vg., inexact quotation). 
the house, and to you they will pay the greater heed. May your holiness have good health, being always mindful of us in Christ.

\section{IV}

To the Brothers in Ireland. November i $48 .{ }^{1}$

(Epistle 37.)

To the religious brothers who are in Ireland, and especially to those communities which Malachy the bishop, of blessed memory, founded, Brother Bernard, called to be abbot of Clairvaux, [wishing them] the consolation of the Comforter. ${ }^{2}$

I. If here we had a continuing city we should rightly mourn with most abundant tears that we had lost such a fellow-citizen. But if 20 rather seck one to come, ${ }^{3}$ as befits us, it is nevertheless no small cause of grief that we are bereaved of a guide so indispensable. We ought, however, to regulate passion with knowledge and to mitigate grief with the confidence of hope ${ }^{4}$ Nor does it become any one to wonder if love compels groaning, if desolation draws forth tears: yet we must set a limit to these things, nay in no small measure be consoled while we gaze not at the things which are seen, but at the things which are not seen: for the things which are seen are temforal, but the things rehich are not seen are eternal. ${ }^{5}$ First, indeed, we ought to rejoice with the holy soul, lest he accuse us of want of charity, saying also himself what the Lord said to the apostles, "If ye loved me ye zeould

1 Clearly this letter must have been pemned a few days after Nalachy's death.

2 Aets ix. 3I, combined will John xiv. 26, ete.

3 Ileb, xiii. 1.4.

${ }^{4}$ Cp. lleb. iii. 6 . ${ }^{5} 2$ Cor. iv. IS. 
rojoice bicause I go unto the Father." 1 'The spirit of our father has gone before us to the Father of spirits, ${ }^{2}$ and we are convicted, not only as wanting in charity, but even as guilty of ingratitude for all the benefits which came to us through him, if we do not rejoice with him who has departed from labour to rest, from danger to safety, from the world unto the Father. ${ }^{3}$ Therefore, if it is an act of filial piety to weep for Malachy who is dead, yet more is it an act of piety to rejoice with Malachy who is alive. Is he not alive? Assuredly he is, and in bliss. In the eyes of the footish he seemed to have died; but he is in peace. ${ }^{4}$

2. Hence even the thought of our own advantage provides us with another motive for great joy and gladness, because so powerful a patron, so faithful an advocate has gone before us to the heavenly court. ${ }^{5}$ For his most fervent charity cannot forget his sons, and his approved holiness must secure favour with God. ${ }^{6}$ For who would dare to suppose that this holy Malachy can now be less profitable [than before] or less loving to his own? Assuredly, if he was loved aforetime, now he receives from God surer proofs of His love, and hating lowed his owen, he lowed them unto the end.7 Far be it from us, holy soul, to esteem thy prayer now less

1 John xiv. 28 .

2 Hel. xii. 9.

3 John xiii. I.-Cp. Serm. i. $\$ 4$ f., "It is the end of labours ... and the entrance to perfect safety. Let us rejoice therefore . . . with our father" ; $\$$, "Threefold is the rejoicing of the man, since he is delivered from all sin and from labour and from danger"; and words ascribed to St. Bernard in I.P'. vii. 49, "Believe, my son, for now thou art about to pass from death to life, from temporal labour to eternal rest."

4 Communio for All Saints' Day (from Wisd. iii. 2, 3).-For the last four sentences of the section cp. Serm. i. $\$ 5$, where an identical passage immediately follows the first parallel quoted in $n .3$.

5 Serm. i. $\$$ I (end) is somewhat similar in expression, and $\S 8$ (end) in thought. There is a closer, but not very striking, parallel in Serm. ii. $\$ 5$ (end).

G Luke ii. 52.

' John xiii. I (inexact quotation). 
effectual, for now thou canst makc supplication with more vigour in the presence of the Majesty, ${ }^{1}$ and thou no longer zealkest in faith, but reignest in the sight of Him. ${ }^{2}$ Far be it from us to count that laborious charity of thine as diminished, not to say made void, now that thou prostratest thyself at the very fountain of eternal charity, quaffing full draughts of that for the very drops of which thou didst thirst before. Charity, strong as death, ${ }^{3}$ yea even stronger than death itself, could not yield to death. For even at the moment of his departure he was not unmindful of you, with exceptional affection commending you to God, and with his accustomed meekness and loweliness ${ }^{4}$ praying our insignificance also that we should not forget you for eqer. ${ }^{5}$ Wherefore also we thought good to write to you that you may know that we are ready to bestow upon you all consolation with entire devotion, whether in spiritual things, if in them our insignificance can ever do anything by the merits of this our blessed father, or in temporal, if ever perchance opportunity should be given us.

3. And now also, dearly beloved, we are filled with heartfelt pity for this grievous bereavement of the Irish Church. ${ }^{6}$ And we unite ourselves the more with you in suffering because we know that by this very thing we have become the more your debtors. For the Lord did sreat things for $u s^{7}$ when $\mathrm{He}$ deigned to honour this place of ours by making it the scene of his blessed death, and to enrich it with the most costly treasure of his body. ${ }^{5}$ But do not take it ill that he is buried among us; for God so ordered, according to the muttitude of His mercies, ${ }^{9}$ that you should possess him in life, and
1 lleb. i. 3 .
${ }^{3}$ Cant, viii. 6.
22 Cor. v. 7 (inexact quotation).
6 Cp. Serm. i. \$ 3 (beginning).
4 Cp. Eph. iv. $2 . \quad 5$ I's, Ixxiv. I9.
\& C. Serm. i. $\$ 2$, "Therefore we render thanks," etc.
9 I's. cvi. 45. 
that it might be allowed to $11 \mathrm{~s}$ to possess him, if only in death. And to us, indeed, in common with you, he was, and still is, father. For even in his death this testament was confirmed to us. ${ }^{1}$ Wherefore as, for the sake of so great a father, we embrace you all as our true brothers, with the unstinted yearning of charity, so also concerning yourselves, spiritua! kinship persuades us that you are like-minded.

4. But we exhort you, brothers, that you be always careful to walk in the steps of this our blessed father, ${ }^{2}$ by so much the more zealously as by daily proofs his holy conversation ${ }^{3}$ was more certainly known to you. For in this you shall prove yourselves to be his true sons, if you manfully maintain the father's ordinances, and if, as you have seen in him, and heard from him how you ought to walk, you so walk that you may abound more and more: ${ }^{4}$ for the glory of a father is the wisdom of his sons. ${ }^{5}$ For even for us the example of so great perfection in our midst has begun in no slight degree both to expel our sloth and impel us to reverence. And would that he may in such wise draze us after him that he may draw us to the goal, rumming more eagerly and more quickly in the fragrance which his virtues have left so fresh behind them. ${ }^{6}$ May Christ guard all of you zillile you pray for us. ${ }^{7}$

1 Ileb. ix. I7 (vg., inexact quotation).

2 Kom. iv. I 2.

32 Pet. iii. I I.

4 I Thess. iv. I (vgr.).

5 Cp. Prov. x. I.

6 Cant. i. 3, 4.-Cp Serm. i. $\$ \&$ (end).

7 Col. iv. 3 . 


\section{SERMONS OF ST. BERNIRD ON THE PASSING OF MALACHY}

\section{SERMON I}

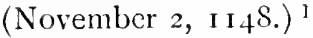

I. A Certain abundant blessing, dearly beloved, has been sent by the counsel of heaven to you this day; and if it were not faithfully divided, you would suffer loss, and I, to whom of a surety this office seems to have been committed, would incur danger. I fear therefore your loss, I fear my own damnation," if perchance it be said, The young children ask bread, and no man offereth it unto them. ${ }^{3}$ For I know how necessary for you is the consolation which comes from heaven, since it is certain that you have manfully renounced carnal delights and worldly pleasures. None can reasonably doubt that it was by the good gift of heaven, and determined by divine purpose,${ }^{4}$ that Bishop Malachy should fall asleep among

1 The evidence that this discourse was delivered on the day of Malachy's death is cumulative. (I) The opening words of $\$ 1$, and the closing sentences of $\$ \$$ (note "this day"). (2), The statement in $\$ 5$, "II said to us, "Wilh desire I have desired," "etc., implies that those who tended Malachy in his sicliness were present (sce Life, $\$ 73$ ). The first person plural in $\$ 2$ suggests the same conclusion. (3) ln $\$ 6$, "dwelling among them "p to this time" implies that his death was not long past. (4) The striking parallels with Letter iv. ; for which see the notes on it. (5) The tone of the sermon-in marked contrast to that of Sermon ii.--indicates that the community was crushed with sorrow for a recent bereavement. See R.I.A. xxxv. 255 ff.

2 dammum uestrum. . dumnationem meam.

3 Lam. iv. 4 (inexact quotation).

${ }^{4}$ Acts ii. 23. 
you to-day, and among you have his place of burial, as he desired. For if not even a leaf of a tree falls to the ground without the will of God, ${ }^{1}$ who is so dull as not to see plainly in the coming of this blessed man, and his passing, a truly great purpose of the divine compassion ? ${ }^{2}$ From the uttcrmost parts of the earth he came ${ }^{3}$ to leave his earth here. He was hastening, it is true, on another errand; but we know that by reason of his special love for us he desired that most of all." He suffered many hindrances in the journey itself, and he was refused permission to cross the sea till the time of his consummation was drawing near, ${ }^{5}$ and the goal which could not be passed. And when, with many labours, he came to us we receined him as an angel of God ${ }^{6}$ out of reverence for his holiness; but he, out of his very deeply rooted meekness and lozeliness, ${ }^{7}$ far beyond our merits, received us with devoted love. Then he spent a few days with us in his usual health: for he was waiting for his companions, who had been scattered in England, when the baseless distrust of the king was hindering the man of God. And when they had all assembled to him, he was preparing to set out to the Roman Court, on his way to which he had come hither ${ }^{8}$ when suddenly he was overtaken by sickness, and he immediately perceived that he was being summoned rather to the heavenly palace, God having

${ }^{1}$ Cp. Matt. x. 29.

${ }^{2}$ Cp. St. Bernard, De Laud. Virg. i. I (P.L. clxxxiii. 56) : "For if neilher a leaf from a tree falls on the eartl without cause, nor one of the sparrows without the heavenly Falber, am I to suppose that a superfluous word flows from the mouth of the holy evangelist?"

${ }^{3}$ Natt. xii. $42 . \quad$ See Life, $\$ 67 . \quad 7$ See Life, $\$ 69$.
6 Gal. iv. I4 (inexact quotation).

${ }^{8}$ He was evidently in haste to resume his journey. And no wonder, for the winter was drawing near, and the sooner the passage of the Alps was made the better for his comfort and safety. Cp. R.I.A. xxxv. 248. "Alpine passes . . become impassable usually about the commencement or middle of October, and remain closed until May" (Sennet, Great St. Bernard, p. 369). 
frovided some better thing for us, lest going out from us he should be made perfect elsewhere. ${ }^{1}$

2. There appeared to the physicians no sign in him, I say not of death, but even of serious illness; but he, gladdened in spirit, said that in every way it was befitting that this year Malacliy should depart from this life. ${ }^{2}$ IVe laboured to prevent it, both by earnest prayers to God, and by whatever other means we could; but his merits prevailed, that his heart's desire should be given him and that the request of his lips should not be withholden. ${ }^{3}$ For so all things happened to him in accordance with his wishes; that by the inspiration of the divine goodness he had chosen this place above all others, and that he had long desired that he should have as the day of his burial this day on which the general memory of all the faithful is celebrated. ${ }^{*}$ Moreover, these joys of ours were worthily increased by the circumstance that we had selected that same day, by God's will, for bringing hither from the former cemetery for their second burial the bones of our brothers. ${ }^{5}$ And when we were bringing them, and singing psalms in the accustomed mamer, the same holy man said that he was very greatly delighted with that chanting. And not long after, he himself also followed, having sunk into a most sweet and blessed sleep. Therefore we render thanks to God for all the things that $\mathrm{He}$ has disposed, because He willed to honour us, unworthy as we are, by his blessed death among us, to enrich IHis poor with the most costly

1 I Iel. xi. 40.

3 P's. xxi. 2.

5 The Iranslation is supposed by Henriquez, Fasciulus Sanctorum Ordinis Cisteriensis, ii. 41. 6 (I.L. Ixxxv. 1559) to luave been made on All Saints' Day, the bones heing reburied on Ail Souls' Day. But Vacandard (K. Q.H. lii. 41 f.) lhinks that the date of the translation was Saturday, October 30. This event probalily marked the encl of the construction of the new monastery of Clairvaux, which began before Malachy's first visit. Sce 1) 7 I, 12. 4 . 
treasure of his body, and to strengthen us, who are weak, by so great a fillar ${ }^{1}$ of His church. For one or other of two signs proves that it was aronght for us for good, ${ }^{2}$ either that this place is pleasing to God, or that it is His will to make it pleasing to Him, since He led to it from the uttermost parts of the earth ${ }^{3}$ so holy a man to die and to be buried there.

3. Ijut our very love for this blessed father compels us to sorrow with that people from our heart, and to shudder exceedingly at the cruelty of him, even I)ath, who has not spared to inflict this terrible wound on the Church, now so much to be pitied. Terrible and unpitying surely is death, which has punished so great a multitude of men by smiting one; blind and without foresight, which has tied the tongue of Malachy, arrested his steps, relaxed his hands, closed his eyes. Those devout eyes, I say, which were wont to restore divine grace to simners, by most tender tears; those most holy hants, which had always loved to be occupied in laborious and humble deeds, which so often offered for sinners the saring sacrifice ${ }^{4}$ of the Lord's body, and were lifted up to heaven in prayer arthout arath and douling; 5 which are known to have bestowed many benefits on the sick and to have been resplendent with manifold signs; those beantiful steps also of him that preached the Crospd of peace and brought shlad tidings of goot things; those fect, ${ }^{6}$ which were so often wearied with eagerness to show pity; those footprints which were always worthy to merit devout kisses ; ${ }^{7}$ finally, those holy lifs of the friest, which keft knozeledge, the mouth of the righteous, which spoke

1 Gal. ii. 9.

3 Matt. xii. 42

1 Tim. ii. S.

7 Cp. Luke vii. 3 S.-Perhaps a reference to St. Bemard's own action just licfore this sermon was preached. Shee p. I 29, n. 6.

8 Mal. ii. 7 .
+2 Mace. iii. 32 (vg.).

6 kom. x. I 5 .
2 l's. lxxxvi. 17 (vg.). 
arisdom, and his tongue which, talkins of judgement, ${ }^{1}$ yea and of mercy, ${ }^{2}$ was wont to heal so great wounds of souls. And it is no wonder, brothers, that death is iniquitous, since iniquity brought it forth, ${ }^{3}$ that it is heedless, since it is known to have been born of seduction." It is nothing wonderful, I say, if it strikes without distinction, since it came from the transgression ${ }^{5}$ if it is cruel and mad, since it was produced by the subtlety of the old serpent ${ }^{6}$ and the folly of the woman. But why do we charge against it that it dared to assail Malachy, a faithful member, it is true, of Christ, ${ }^{7}$ when it also rushed madly upon the very head of s Malachy and of all the elect as well? It rushed, assuredly, upon One whom it could not hurt; but it did not rush away unhurt. Death hurled itself against life, and life shut up death within itself, and death was sacalloreed at of lifi.9 Gulping down the hook to its hurt, it legan to be held by Him whom it seemed to have hetd. ${ }^{11}$

1 l's. xxxvii. 3 o.

2 l's. ci. I.

3 Jas. i. 15.

4 C. 2 Cor. xi. 3 ; I Tin. ii. 14.-See J. lI. lernard on 2 Cor. xi. 3 (Expositor's (rrect Tislament).

5 I Tim. ii. I.4.

7 I Cor. vi. I 5 , ete.

9 I Cor. xv. 54, combined with 2 Cor. v. 4.

$10 \mathrm{Cp}$. Cant. xxvi. I 1 : "Thou art dead, () death, and pierced by the hook thou hast imprudently swallowed, which saith in the words of the prophet, ' $O$ death, I will be thy death ! O hell, 1 will be thy bite.' l'ierced, I say, by that hook, to the faithful who go through the midst of thee thon offerest a broad and pleasant paithway into life" (Morison's translation). A very old metaphor. It is thus cxplained by Rufinus (A.D. 4OO) in his Commentary on the Apostles' Creed (\$ 16 , Heurtley's translation) : "The olject of that nystery of the Incarmation. . Was that the divine virtue of the Son of fiod, as thomgl it were a hook enncealed bencath the form and fashion of human flesh, . . might lure on the prince of this world to a contlict, to whon offering litis llesh as a hait, Ilis divinity undemeath might secure him, caught with a hook by the shedeling of Ilis immacilate lolood. . . . $\Lambda \mathrm{s}$, if a fish seizes a baited hook, it not only does not take the hait off the hook, hut is drawn out of the water to he itself food for others, so he who harl the power of death seized the body of Jesus in cleath, not being aware of the houk 
4. But perhaps some one may say, How does it appear that death has been overcome by the Head, if it still rages with so great liberty against the members? If death is dead, how did it kill Malachy? If it is conquered how has it still power over all, and there is no man that liveth and shall not see death? 1 Death is clearly conquered-the work of the devil ${ }^{2}$ and the penalty of $\sin$ : $\sin$ is confuluered, the cause of death; and the wicked one himself is conquered, ${ }^{3}$ the author both of $\sin$ and death. And not only are these things conquered, they are, moreover, already judged and condemmed. The sentence is determined, but not yet published. In fact, the fire is prepared for the devil, "though he is not yet cast into the fire, though still for a short time ${ }^{5}$ he is allowed to work wickedness. He is become, as it were, the hammer of the Heavenly Workman, the hanmer of the whole earth. ${ }^{6}$ IIe crushes the elect for their profit, ${ }^{7}$ he crushes to powder the reprobate for their damnation. As is the master of. the house, so are they of his houschold, 8 that is, sin and death. For sin, though it is not to be doubted that it was nailed with Christ to His cross, ${ }^{\mathbf{9}}$ was yct allowed still for a lime, not indeed to reign, ${ }^{10}$ but to dwell even in the Apostle himself while he lived. I lic if he does not himself say, It is no more I that do it, lnt sin dwoclleth in me. ${ }^{11}$ So also death itself is by no means, indeed, yet compelled not to be present, but it is compelled not to be present to men's hurt. But there will come a time when it is said, $O$ death, where is thy victory? ${ }^{12}$ For death also is

of divinity enclosed within it, but, having swallowed it, he was caught forthwith, and the lars of bell bejug burst asunder, he was drawn forth as it were from the alyss to become fool for others."
1 l's. Ixxxix. 48 ( $\mathrm{rg}$. ).
I John ii. I3, I4.
5 Rev. xii. I 2.
8 Matt. x. 25.
1) kom. vii. 17.
21 John iii. 8 .
4 Matt. Xxv. 4 I.
"Jer. 1. 23 .
7 I Cor. xii. 7 (vg.).
10 Rom. vi. 12.
12 I Cor. Xv. 55 (vg.). 
the last enemy that shall be destroyed. ${ }^{1}$ But now, since He rules zetro has the power of life and death ${ }^{2}$ and confines the very sea within the fixed limits of its shores, death itself to the beloved of the Lord is a sleep of refreshment. The prophet bears witness who says, When he giveth his beloved sleep, behold the heritage of the Lord. $^{3}$ The death of the wicked is indeed most evil, ${ }^{4}$ since their birth is evil and their life more evil; but precious is the death of the saints. ${ }^{5}$. Precious clearly, for it is the end of labours, the consummation of victory, the gate of life, and the entrance to perfect safety.

5. Let us rejoice therefore, brothers, let us rejoice as is meet, with our father, for if it is an act of filial piety to mourn for Malachy who is dead, yet more is it an act of piety to rejoice with Malachy who is alive. Is he not alive? He is, and in bliss. Certainly, in the eyes of the foolish he seemed to have died, ; but he is in peace. ${ }^{6}$ In fine, now a fcllow-citizen with the saints, and of the household of $\operatorname{God}^{7}{ }^{7}$ he at once sings and gives thanks, saying, We went through fire and water; but thou broughtest us out into a wealthy place. ${ }^{8}$ He went, clearly, in manly fashion, and he went through ${ }^{9}$ happily. The true Hebrew celebrated the Passover in spirit, and as he went, he said to us, "With desire I have desired to eat this Passover with you." 10 He went through fire and water, ${ }^{11}$ whom neither experiences of sadness could crush, nor pleasures hold back. For there is below us a place which fire wholly claims as its own, so that the wretched

1 I Cor. xv. 26.

3 Ps. cxxvii. 2, 3 (vg.).

2 IIeb. ii. I $_{4}$; Tobit ii. 8 .

4 l's. xxxiv, 21 (vg.).

5 Ps. cxvi. 15.

6 Communio for All Saints (Wist. iii. 2, 3).

7 Eph. ii. 19 (with variant).

8 Ps. Ixvi. 12.

9 IJos. x. I5 (vg. : xi. I).

10 Lule xxii. I5.-See Life, \$73, where for "he said to us" we have "lifing up his eyes on those z'ho stood round him, he said."

11 P's. Ixvi. 12, 
I)ives could not have there even the least drop of watcr from the finger of Lasarus. ${ }^{1}$ 'There is also above the city of God which the streams of the river make glad, ${ }^{2}$ a torrent of pleasure, ${ }^{3}$ a cup which inebriates, how goodly ! ${ }^{4}$ Here, in the midst, truly is found the knowledge of good and cvil, ${ }^{5}$ and in this place we may receive the trial of pleasure and of affiction. ${ }^{6}$ Unhappy Eve brought us into these alternations. Here clearly is day and night; for in the lower world there is only night, and in heaven only day. ${ }^{7}$ Blessed is the soul which passes through both, neither ensnared by pleasure nor fainting at tribulation. 8

6. I think it right to relate to you, briefly, a specimen of the many splendid deeds of this man, in which he is known to have gone, with no little vigour, through fire and water. ${ }^{9}$ A tyrannous race laid claim to the metropolitan see of Patrick, the great apostle of the Irish, creating archbishops in regular succession, and possessing the sancluary of God by hereditary right. ${ }^{10}$ Our Malachy was therefore asked by the faithful to combat such great evils; and putting his life in his hand ${ }^{11}$ he advanced to the attack with vigour, he undertook the archbishopric, exposing himself to cvident danger, that he might put an end to so great a crime. Surrounded by perils he ruled the church; when the perils were passed, immediately he canonically ordained another as his successor. For he had undertaken the office on this. condition, that when the fury of persecution had ceased and it thus became possible that another should safely be appointed, he should be allowed to return to

\footnotetext{
1 Luke xvi. 24, 25.

3 P's. xxxvi. S (vg.).

5 Gen. ii. 9.

7 lev. xxi. 25 ; xxii. 5.

9 Ps. lxvi. 12.

11 I Sam. xix. 5.
}

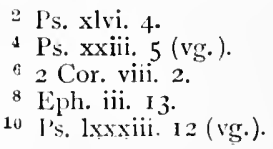

2 Ps. xlvi. 4.

4 Ps. xxiii. 5 (vg.).

a 2 Cor. viii. 2.

8 Eph. iii. ${ }_{3} 3$.

10 P's. lxxxyiii. 12 (vg.). 
his own see. ${ }^{1}$ And there, without ecclesiastical or secular revenues he lived in the religious communities which he himself had formed, dwelling among them up to this time as one of themselves, and abjuring all personal property. ${ }^{2}$ So the fire of affiction tried ${ }^{3}$ the man of God, but did not consume him; for he was gold. So neither did pleasure hold him captive or destroy him, nor did he stand a curious spectator on the way, forgetful of his own pilgrimage.

7. Which of you, brothers, would not earnestly desire to imitate his holiness, if he dared even to hope for such an attainment? I believe, therefore, you will gladly hear, if I perchance can tell it, what made Malachy holy. But lest our testimony should seem not easy to be received, hear what the Scripture says : He made him holy in his faith and meekness. ${ }^{5}$ By faith he trampled on the world, as John bears witness when he says, This is the victory that owerometh the world, even our faith." For in the sfirit of meekness ${ }^{7}$ he endured all things whatsoever that were hard and contrary with good cheer. ${ }^{8}$ On the one hand, indeed, after the example of Christ, by faith he trampled on the seas, ${ }^{9}$ lest he should be entangled in pleasures; on the other, in his faticnie he possessed his soul, ${ }^{10}$ lest he should be crushed by troubles. For concerning these two things you have the saying in the Psalm, A thousand shall fall at thy side, and ten thousand at thy right hand; ${ }^{11}$ for many more are cast down by the diceitfulness of prosperity than by the lashes of adversity. Therefore, dearly beloved, let none of us, allured by the level surface of the easier way,

1 See $L i f i, \$ \S \mathbf{1} 9^{-} \mathbf{3}^{1}$.

3 Ps. Ixvi. IO, II.

5 Ecclus. xlv. 4 (vg.).

7 Gal. vi. I.

${ }^{9}$ Cp. Malt. xiv. 25 ; John vi. I9.

10 Luke xxi. 19.
2 See p. $\$ 2$, n. 5 .

- Examinanit, non cinaniuit.

${ }^{6}$ I John v. 4.

8 1 Kings xxi. 7 ( $\mathrm{vs}$.$) .$

11 I's. xci. 7. 
suppose that road of the sea to be more convenient for himself. This plain ${ }^{1}$ has great mountains, invisible indeed, but for that very reason more dangerous. That way perhaps seems more laborious which passes through the steeps of the hills and the ruggedness of rocks; but to them that have tried it, it is found far safer and more to be desired. But on both sides there is labour, on both sides danger, as he knew who said, By the armour of righteousness on the right hand and on the left; ${ }^{2}$ so that we may rightly rejoice with those that aient through fire and weater and have been brought into a wealthy place. ${ }^{3}$ Do you wish to hear something about the zealthy place? Would that another might speak to you of it. For as for me, that which I have not tasted I cannot inclite.

8. But I seem to hear Malachy saying to me to-day about this wealthy place, Return unto thy rest, $O$ my soul; for the Lord hath dealt bountifully with thee: for he hath delivered my soul from death, [mine eyes from tears, and my feet from falling ${ }^{4}$. And what I understand to be expressed in those words hear in a few sentences; for the day is far spent, ${ }^{5}$ and I have spoken at greater length than I intended, because I am unwilling to tear myself away from the sweetness of the father's name, and my tongue, dreading to be silent about Malachy, fears to cease. The death of the soul, ${ }^{6}$ my brothers, is sin; unless you have overlooked that which you have read in the prophet: The soul that sinneth, it shall die. ${ }^{7}$

1 That is, the sea. The details of the imagery are not clear. but evidently the sea represents the pleasures, and the hills and rocks the adversities, of life.
22 Cor. vi. 7.
3 Ps. Ixvi. I2.

4 Ps. cxvi. 7, S (vg.).-The printed text has, in place of the lracketed words, "and so forth." The threefold deliverance obviously corresponds to the threefold rejoicing mentioned below, sin being substituted for death in the description of it, because "the death of the soul is sin."
5 Luke xxiv. 29.
- Cp. Ps. cxvi, S,
7 Ezk. xviii. 4 . 
Threefold, then, is the rejoicing of the man, since he is delivered from all sin, and from labour, and from danger. For from this time neither is $\sin$ said to drecll in him, ${ }^{1}$ nor is the sorrow of penitence enjoined, nor from henceforth is he warned to guard himself from any falling. ${ }^{2}$ Elijah ${ }^{3}$ has laid aside his mantle; ${ }^{4}$ it was not that he feared, it was not that he was afraid that it should be touched, still less retained, by an adulteress. ${ }^{5}$ He went up into the chariot; ${ }^{6}$ he is not now in terror of falling; he mounts delightfully; he labours not to fly by his own power, but sits in a swift vehicle. To this zecalthy place, dearly beloved, let us run with all eagerness of spirit, in the fragrance of the ointments of this our blessed father, who this day has been seen to have stirred up our torpor to most fervent desire. Let us run after him, I say, crying to him again and again, "Drate us after thee" ${ }^{7}$ and, with earnest heart and advancing holiness of life, returning devout thanks to the Almighty Pity, that He has willed that Ifis unworthy servants, who are without merits of their own, should at least not be without the prayers of another.

1 Rom. vii. 17, 20. 2 P's. cxvi. S.

3 For other comparisons of Malachy with Llijah, see Life, $\$ 23$; Serm. ii. \$ $\mathrm{S}$.
42 Kings ii. 13 .
62 Kings ii. 1 .
5 Gen. xxxix. 12, I 5 ( $\mathrm{vg}$.$) .$
7 Cant. i. 3, 4 . 


\section{SERMON II}

\section{(November 2, I I 49) $^{\mathbf{1}}$}

I. IT is clear, dearly beloved, that zollilst z'e are detained in the body zoe are absent from the Lord. ${ }^{2}$ And throughout this wretched time of detention banishment and conscience of faults enjoins upon us sorrow rather than joy. But because by the mouth of the apostle we are exhorted to rejoice with them that do rejoice, ${ }^{3}$ the time and the occasion require that we should be stirred up to all gladness. For if it is true, as the prophet perceived, that the rishtiteous rejoice before God, ${ }^{4}$ without doubt Malachy rejoices, who in his days ${ }^{5}$ pleased $\mathrm{God}^{6}$ and reas foum righteous. ${ }^{7}$ Malachy ministered in holiness and righteousness before Him: ${ }^{\text {s }}$ the ministry pleased Him; the minister also pleased Him. Why should he not please Him? He made the Gospel without charse, ${ }^{9}$ he filled the country with the Gospel, he tamed the deathly barbarism of his Irishmen, with the stord of the spirit ${ }^{10}$ he subdued foreign nations to the light yoke of Christ, ${ }^{11}$ restoring His inheritance to $\mathrm{Him}^{12}$ even unto the ends of the earth. ${ }^{13} \mathrm{O}$,

1 It is platin from $\$ 7$ that this sermon was preached on an anniversary of Malachy's death, i.e. on November 2 , in a year later than 1148. I put it in 1149 because of its striking coincidences with the Life, which was written early in that year (see p. $\mathbf{x v}$ ). There is also a possible echo $(\$ 3)$ of De Cons. i. which belongs to the same year (P.L. clxxxii. 723). These, together with two coincidenees of phrase with olher writings of St. Bernard, are pointed out in the notes, See R.I.A. xxxy, $260 \mathrm{ff}$.

2 Cor. v. 6.

4 I's. Ixviii. 3.

6 Eeclus. xliv, I6 (vg.).

8 Luke i. 75.

10 Eph. vi. I7.

12 Ps. xvi. 5 (vg.).

3 Rom. xii. 15.

5 Eeclus. xliv. 7 .

7 Ecclus. xliv. 17.

9 I Cor. ix. I $8 .-$ Cp. Life, $\$ 43$ (p. \$4).

11 Matt. xi. 3 o.

13 Isa. xiviii. 20 ; Jer. xxv. 3!. 
fruitful ministry! $O$, faithful minister! Is not the promise of the Father to the Son fulfilled through him? Did not the Father behold him long ago when He said to the Son, I shall give thee the heathen for thine inheritance, and the uttermost parts of the earth for thy possession. ${ }^{1}$ How willingly the Saviour received what He had bought, ${ }^{2}$ and had bought with the price ${ }^{3}$ of His own blood, ${ }^{4}$ with the shame of the Cross, with the horror of the Passion. How willingly from the hands of Malachy, because he ministered freely. ${ }^{5}$ So in the minister the freely executed office was acceptable, ${ }^{6}$ and in the ministry the conversion of sinners was pleasing. Acceptable and pleasing, I say, in the minister was the singleness of eye, ${ }^{7}$ but in the ministry the salvation of the people. ${ }^{8}$

2. However, even though a less effective result of the ministry followed, He would nevertheless justly have had regard to Malachy and his works, He to whom purity is a friend and single-mindedness one of his household, to whose righteousness it belongs to weigh the work in accordance with its purpose, from the character of the eye to measure the state of the whole body." But now the works of the Lord are great, sought out according to all the desires ${ }^{10}$ and efforts of Malachy; they are great and many and very good, ${ }^{11}$ though better in proportion to the good origin of the pure purpose. What work of piety escaped the attention of Malachy? He was poor as regards himself, but rich to the poor. He was a father of the fatherless, a husband of the widowes, ${ }^{1:}$ a protector of the oppressed. A cheerful giver, ${ }^{13}$ seldom

1 Ps. ii. 8.

3 I Cor. vi. 20.

s 2 Cor, xi. 7 .

7 Matt. vi. 22 : Luke xi. 34.

9 Matt. vi. 22, 23; Luke xi. 34, 35.

11 Gent. i. 3 I. 12 I's. Ixviii. 5.
2 l'et. ii. I.

1 Acts xx. 28.

6 Gratum trat munus gratuitum. llab. iii. 13.

13.

132 Cur. is. 7. 
making petitions, modest in receiving gifts. He was specially solicitous, and had much success, in restoring peace between those who were at variance. Who was as tender as he in sharing the sufferings of others? who as ready to help? who as free in rebuke? For he was zealous, and yet not wanting in knowledge, the restrainer of zeal. And, indeed, to the weak he was weak, ${ }^{1}$ but none the less strong to the strong: he resisted the proud, ${ }^{2}$ he lashed the tyrants, a teacher of kings and princes. It was he who by prayer deprived a king of sight when he worked wickedness, and restored it when he was humbled. ${ }^{3}$ It was he, when certain men broke a peace which he had made, who gave them up to the spirit of error, ${ }^{4}$ and foiled them in the evil which they devised to do; and who compelled them to accept peace a second time, confounded and stumned by that which had happened to them. It was he ${ }^{5}$ to whom a river most opportunely lent its aid against the others, who were equally transgressors of a covenant. ${ }^{6}$ In wonderful fashion, by throwing itself before them, it made void the efforts of the ungodly. There had been no rains, no floods of waters, no gathering of clouds, no melting of snows, when suddenly the mere rivulet was converted into a great river; and it rushed along ${ }^{7}$ and swelling up overflowed the banks, and utterly denied passage to those who wished to do wickedly. ${ }^{8}$

3. What things we have heard and known of the wrath of the man and his rengeance on his enemies,

1 I Cor. ix. 22.

3 See Life, \$6o.

5 Printed text, Ipse enim est. With A I omit inim.

6 Josh. vii. I5, etc.

7 So A : cicius (= citius) ibat for rimus ibat of the printed text.

8 The story is told much more fully in Life, $\$ \$ 5 \$, 59$; where there are many similarities in phraseology to the present passage. In both places it is connected with the miraculous blinding of the king, immediately preceding it here, immediately following it there. 
while yet he was sueet and gentle and plenteous in morcy unto all ${ }^{1}$ that suffered need! For he lived for all as though he were the one parent of all. ${ }^{2}$ As a hen her chickens, ${ }^{3}$ so he cherished all and protccted them under the covert of his wings. ${ }^{4}$ He made no distinction of sex or age, of condition or person ${ }^{5}$ he failed none, his loving heart embraced all. In whatsoever affliction men cried to him he counted it his own : even more than that, for in regard to his own affictions he was patient, in regard to those of others he was compassionate, very often even passionate. For indeed sometimes, filled with wrath, he was stirred to take the part of one against another, that by delivering the poor and restraining the strong ${ }^{6}$ he might take thought in equal measure for the salvation of all. Therefore he was angry; but it was in order that he might not $\sin$ by not being angry, according to the words of the Psalm, Be ye angry and sin not. ${ }^{7}$ Anger did not rule him, but he himself ruled his spirit. ${ }^{8}$ He had power over himself. Assuredly he who had the victory over himself could not be mastered by anger. ${ }^{9}$ His anger was kept in hand. When it was summoned it came, going forth, not bursting forth; it was brought into action by his will, not by impulse. He was not set on fire by it, but used it. ${ }^{10}$ As well in this as in ruling and restraining all the motions both of his inner and his outer man ${ }^{11}$ his judgement was careful, his caution great. For he did not give so much attention to all, as to leave himself alone out of account,

1 Ps. Ixxxvi. 5 (vg.).

$2 \mathrm{Cp}$. the description of Malchus, Life, $\$ 8$ : "He was reverenced by all, as the one father of all"; and of Malachy, $\$ 33$ : "the loving father of all."
3 Matt. xxiii. 37.
1 Ps. Ixi. 4 (vg.).

$5 \mathrm{Cp}$. Life, $\$ 42$ : "Neither sex nor age, nor condition nor profession, is held in accomt."
if I's. $x x x y$. Io.
${ }^{8}$ Prov. xvi. 32.
10 Non urebatur illa, sed utebatur.
7 Ps. iv. 4 (vg.).
9 Job xxxvi. is (vg.).
11 Utriusque hominis sui. 
as, in his universal solicitude, to disregard only himself. He was careful of himself also. He guarded himself. ${ }^{1}$ In fact, he was so wholly his own, so wholly also belonged to all, that his love seemed in no degree to hinder or delay him from his guardianship of himself, nor his concern for his own person from the common good. ${ }^{2}$ If you saw the man busied in the midst of crowds, involved in cares, you would say he was born for his country, not for himselj. ${ }^{3}$ If you saw the man alone and dwelling by himself, you would suppose that he lived for God alone and for himself.

4. Without tumult he went about among tumults; without ease he spent the time which he gave to ease. How could he be taking his ease ${ }^{4}$ when he was occupied. in the statutes of the Lord? 5 * For though he had time free from the necessities of the peoples, yet had he none unoccupied by holy meditations, by the work of prayer, by the ease itself of contemplation. In the time of ease he spoke gravely or not at all. His mien was either courteous, or humble and self-restrained. Assturedly-a trait which is counted worthy of much praise among the wise-his eye was in his head, ${ }^{6}$ never flying forth except when it was obedient to power. His laughter displayed love, or provoked it : but even so it was rare. Sometimes indeed, it came forth, but it was never forced, intimating the gladness of his heart in such a way that

1 I Tim. v. 22.

2 Cp. De Cons. i. 6: "If you desire wholly to belong to all ... I praise your humility, but only if it is complele. But how can it be complete if you exclude yourself? And you are a man. Then, that your humanity also may be complete, let the bosom which receives all gather you also within itself. . . . wherefore, where all possess you let you yourself also be one of those who possess."

3 lucan, lhars. ii. 383 .

4 C. De Cons. iv. I 2, "I' eace not taling ease;" Life, \$ 43 , "Quiet often, lut by no means at any time taking ease."

5 1's. exix. 23.

6 Eccles. ii. 14 (inexact quotation). 
his mouth did not lose but gained in grace. ${ }^{1}$ So modest was it that it could not be suspected of levity ; so gentle," however, that it sufficed to free his joyous countenance from every trace and shadow of sadness. ${ }^{3} \mathrm{O}$ perfect gift! O rich burnt sacrifice! ${ }^{4} \mathrm{O}$ pleasing service in mind and hand! How swect unto God is the savour ${ }^{5}$ of him who employs his leisure in prayers, how sweet unto men of him who is occupied in fatiguing labours.

5. Because he was such an one, then, beloved of God ${ }^{6}$ and men, not undeservedly was Malachy received this clay into the company of angels, having attained in fact what his name denoted. ${ }^{7}$ And indeed, already he was an angel not less in purity than in name. But now more happily is the significance of his glorious name fulfilled in him, since he is glad with a glory and happiness equal to that of the angels. ${ }^{8}$ Let us also, dearly heloved, be glad because our angel ascended ${ }^{9}$ to his fellow-citizens, acting as an ambassador for the children of the captivity, ${ }^{\mathbf{1 0}}$ winning for us the favour of the blessed ones, declaring to them the desires of the wretched. Let us be glad, I say, and rejoice, ${ }^{11}$ because in that heavenly court ${ }^{12}$ there is one who went forth from us to take care of us, ${ }^{13}$ to protect us by his merits, ${ }^{14}$ whom

1 Cp. Luke iv. 22.

2 Tinntillus. The text seems to be corrupt. Read tam lacus?.

"Cp. Life, \$ 43: "Yea, what was there that was not edifying," etc.

+ Ps. xx. 3 (vg.). 2 Cor. ii. 15.

6 I Thess. i. 4 (vg.) ; 2 Thess. ii. 13.

7 That is, Nalachias, the Ilebrew for my ansel, with a Latin termination. For its origin see $L i j e, \$ 2$.

8 At this point, with $\mathbf{A}, 1$ omit a pasage which is identical will the first half of Serm. i. S 5, and interrupts the argument. With $A$, also, in the following sentence I read Lactemur et nos dilectissimi quod for Lactemur quod of the printed lext. See R.I.A. xxxv. $260-262$.

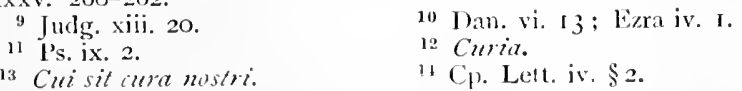


he instructed ${ }^{1}$ by his example and strengthened ${ }^{2}$ by his miracles.

6. The holy pontiff, who in a humble spirit ${ }^{3}$ often brought peace-offerings to the heavens, to-day in his own person has gone unto the altar of $G o d^{3},{ }^{4}$ himself the victim and the priest. With the departure of the priest the rile of sacrifice is changed into a better thing. 'The foluntain of tears ${ }^{5}$ is dried up, every burnt sacrifice is made with gladness and rejoicing. ${ }^{6}$ Blessed be the Lord God of Malachy, who by the ministry of so great a pontiff hath visited his people, ${ }^{7}$ and now, taking him up into the holy city, ${ }^{8}$ ceaseth not, by the remembrance of so great sweetness to comfort our captivity. ${ }^{9}$ Let the spirit of Malachy rejoice in the Lord, ${ }^{10}$ because he is freed from the heavy load of the body, and is no longer hindered, by the weight of impure and carthly matter, from passing with all eagerness and fullness of life, through the whole creation, corporeal and incorporeal, that he may enter entirely into God, and joined to Him may with Him be one spirit ${ }^{11}$ for ever. ${ }^{12}$

7. Holiness becometh that housc ${ }^{13}$ in which the remembrance of so great holiness ${ }^{14}$ is celebrated. Holy Malachy, preserve it in holiness and righteonsness, ${ }^{15}$ pitying us who in the midst of so many and great miseries utter the

1 Informanit.

3 Song of Three Children, 16.

5 Jer. ix. I.

7 Luke i. 65.

9 H's. cxxvi. I, 4 (vg.). 10 Luke i. 47

2 Confrmanit.

1 Ps. xliii. 4.

6 Ps. xlv. I 5.

8 Mall. iv. 5 .

12 Sec $D_{t}$ Cons. v, 2, quoted p. I $2 \%$, n. I 3 , and the semon on the Marriage of the Soul with the Word (Cant. Ixxxiii. 6), in which Sit. Bernard, quoting I Cor. vi. 17, says, "Love . . joins the iwo in one spitit, makes them no longer two but one." Cp. also Cant. xxvi. 5 : "Ite that is joined to God is one spirit, and is wholly changed into a certain divine feeling, and cannot think of or mind anylhing but God, and that which God thinks and minds, being full of Gorl." l"or the last phrase sce lgnatius, NIagn. I4.

13 Ps. xciii. 5.

14 l's. $\mathrm{xxx} .4$.

15 Like i. 75. 
memory of thine alundant goodness. ${ }^{1}$ Great is the dispensation of the mercy of God upon thee, who made thee little in thine owon sight, ${ }^{2}$ great in $\mathrm{His}$; who did great things by thee, in saving thy country, great things to thee, ${ }^{3}$ in bringing thee into His glory. May thy festival, which is deservedly devoted to thy virtues, have a saving efficacy for us by thy merits and prayers. May the glory. of thy holiness, ${ }^{1}$ which is celebrated by us, be continued by angels : so shall it meetly be pleasant for us, if it be also fruitful. While thou departest be it allowed to us, who are met together to-day in thy so delicious feast, to preserve some remnants of the fruits of the Spirit, loaded with which thou ascendest.

S. Be to us, we beseech thee, holy Malachy, another Moses, or another Elijah, like them imparting of thy spirit 5 to us, for thou hast come in their spirit and pozer." "Thy life was a lawe of life and know'ledge, ${ }^{7}$ thy death the port of death and the portal of life, ${ }^{s}$ thy memory the delight of sweetness and grace, thy presence a crow'n of glory in the hand of the Lord" thy God. O fruitful olive tree in the house of God! ${ }^{10} \mathrm{O}$ oil of gladness, ${ }^{11}$ giving both anointing and light, cherishing with favours, resplendent with miracles, ${ }^{12}$ make us partakers of that light and graciousness which thou enjoyest. ${ }^{13} \mathrm{O}$ sweet-smelling lily, blossoming and budding evermore before the Lord, and spreading everywhere a steet and life-giving savour, ${ }^{14}$ zohose memorial is blessed ${ }^{15}$ with us, whose presence is in honour with those who are above,

1 Ps. cxlv. 7 (vg.).

3 Luke i. 49.
5 Num. xi. $25 ; 2$ Kings ii. 9, 15.

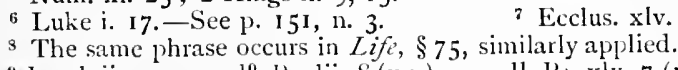

9 Isa. Ixii. 3 . 10 I's. lii. $S$ (vg.).

12 Epiphany Collect. 13 Cp. Life, $\$ 47$ (p. 88).

14 Isa. xxvii. 6, combined with Hos. xiv. 5, and Écclus. xxxix. I4.

15 Ecclus. xlv. I.
2 I Sam. xv. I7 (inexact quotation).

4 Ps. cxlv. 5 (rg.).
- Ecclus. xlv. 5 . 
grant to those who sing of thee that they may not be deprived of their share in so great an assembly. ${ }^{1}$ Ogreat luminary ${ }^{2}$ and light that shinest in darkness, ${ }^{3}$ illuminating the prison, making glad the city 4 by the rays of thy signs and merits, by the lustre of virtues put to flight from our hearts the darkness of vices. $\mathrm{O}$ moming star, 5 more brilliant than the rest because thou art nearer the day, more like to the sun, deign to go before us, that we also may zolk in the light as children of light, and not children of darkness. ${ }^{6} \mathrm{O}$ thou who art the dawn breaking into day upon the earth, but the noon light 7 illumining the higher regions of heaven, receive us in the fellowship of light, by which illuminated thou sheddest light far without, and sweetly burnest within, by the gift of our Lord Jesus Christ, who with the Father and the Holy Spirit reigneth One God, world without end.-AMEN.

1 Ecclus. xxiv, 2, I 2 (vg.). The clauses containing the word assembly (flenitudo) are omitted in R.V.

2 Ps. cxxxvi. 7 .

4 Ps. xlvi. 4.

3 John i. 4.

5 Ecclus. 1. 6.

6 1 John i. 7, combined with 1 Thess. v. 5.

7 Isir. xviii. 4 (vg.). 


\title{
ADDITIONAL NOTES
}

\author{
A.-St. bernard's Description of the State of the \\ IRISH CHURCH.
}

$$
\text { Life, } \$ \$ 7,16,17 .
$$

In two passages of the Life serious charges are male against the Irish Church of the early years of the twelfth century. These charges refer primarily to the dioceses of Armagh and Connor ; but it is probable that those dioceses were typical of many other districts throughout the country. If St. Bernard's statements are true of them, they may be applied with little reserve to the greater part of Ireland. Indeed he himself gives us more than a hint that the abuses which he condemns were by no means confined to eastern Ulster (\$ I9). It may be well, therefore, to bring them together and to discuss them.

I. There was no such thing as chanting at the canonical hours. In the whole bishopric of Armagh "there was none who could or would sing" (\$ 7). "In the churches [of Connor] there was not heard the voice either of preacher or singer" (\$ 16$)$. We may suspect that there is some exaggeration here; for if ehurch song was absolutely unknown, how could Malachy have "learnt singing in his youth " $(\$ 7)$ ? But that St. Bernard's remarks are substantially correct need not he questioned. Ile is not speaking of the Irish Church as it was in its earlier period, but of its state at the time when it had probably fallen to its lowest depth. His assertion, therefore, is not disposed of by references to the chanting at the funerals of Brian Boroimhe in IOI 4 and Mlaelsechlainn in 1022 (O'Hanlon, p. 34). Indeed in the notices of those events in $A . F . M$. there is no express mention of ecclesiastical song.

2. At Armagh Confession was not practised (\$7); in the diocese of Connor "nowhere could be found any who would either seek penance or impose it " $(\$ 16)$. It may be true that Confession had been much neglected among some classes of the people: Malachy on one occasion met a woman who had never confessed ( $\$ 54)$, and the very fact that he put the question to her "whether she had ever confessed her sins " suggests that she was not singular in this respect. Jut it is remarkable that the anmchara (soul-friend), or Confessor, is frequently mentioned in Irish literature. The obits of several persons to whom that title is given are recorded in the Annals in the twelfth century. And pennce is often alluded to in the 
obituary notices of distinguished persons, clerical and lay. In his sweeping statement St. Bernard may have harl in mind some differences of method in penitential discipline between the Roman and Irish Churehes.

3. The sacrament of Confirmation was not celebrated, at any rate in Armagh $(\$ 7)$. This rite has always been used in the Irish Church, though possibly neglected locally at some periods. St. l'atrick tells ts that he "contirmed in Christ" those whom he had "begotten to God" (Epistle, 2 ; cp. Confession, 38, 51)-thus giving us one of the earliest instanees in literature of the application to the rite of its present familiar name. But in his practice (Efistle, $\S 3$ ), as in the Stowe Missal, about A.1). Soo (ed. Sir G. F. Warner, vol. ii. p. 3I), it seems to have consisted of an anointing with chrism without laying on, or raising, of hand, or a direct prayer for the Holy Spirit. According to the Stowe Missal it was administered by a presbyter. It is improbable that St. Bernard or his romanizing friends would recognize the rite so performed as true Confirmation.

4. One of the things which was neglected at Armagh was "the marriage contract " $(\$ 7)$. In the diocese of Connor there was " no entry into lawful marriages" (\$ 16$)$. By the labours of Malachy this abuse disappeared. In Armagh he "instituted anew" the marriage contract ; in Connor it came to pass that "the celebra tion of marriage" was revived ( $\$ 17)$. l'utting these statements together we may conclude that St. Bernard's meaning is that marriages had ceased to be celebrated in the face of the Church, and that in consequence the vow of a life-long union was often evaded. Now contemporary writers eharge the Irish of this period with loose sexual morality, especially in regard of arbitrary divoree, matrimony within the prohibited degrees, exchange of wives, and other breaches of the kaw of marriage. Such accusations are male, for example, by l'ope Gregory VII. (Haddan and Stubbs, Eccl. Docs. ii. 160), Lanfrane (Ussher, 490; P.L. cl. 535, 536), Anselm (Ussher 521, 523; P.L. clix. 173,178 ) and Giraldus Cambrensis (Gest. ii. 14; Top. iii. 19). Their evidence is the more worthy of credence because the usages to which they refer were characteristic of the lrish at an earlier period (Encycl. of Keligion and Ethics, v. 456,460 ), and might be expected to recur in an age of spiritual decline. But both Lanfranc and Anselm testify to the existence of marriage as an institution among the Irish. The former speaks of the divorce of a wife "lawfully joined to her husband," and the latter uses terms of similar import. So also does St. Bernard himself. His praise of Malachy's mother (Lif,$\$ 1)$ is inconceivable if she did not live in wedlock; and he expressly states that eight "metropolitans" of Armagh were "married men" (\$19). But if there was nevertheless a revival among large sections of the people of pagan ideas of marriage, which tolerited polygamy, coneubinage, incest and easy termination of unions, it can be understood that marriage in the face of the Church, which included a vow absolutely prohibitive of all these things, would be commonly avoided. Malachy's anxiety 
to restore the marriage ceremony was no doubt due to a desire to purge the nation of immoral customs of which St. Bernard makes no express mention. But, however that may be, we have contemporaly native evidence that the rite of marriage had fallen into lesuetude, and that Malachy was successful in his effort to restore it. For in the document quoted on p. 170, we are told that in a district which was part of the diocese of Armagh when he was Ce!lach's vicar (L.A.J. iv. 37), and under the rule of his patron, Donough O'Carroll, "marriage was assented to."

5. "There was no giving of tithes or firstfruits," writes St. licumard (\$ I6). He is speaking of the diocese of Connor. But there is no doubt that the remark might have been made of other districts. There was no such custom as the payment of tithes in lreland before the twelfth century. They are first mentioned by Gilhert of Limerick, ahout I IOS, in his De Statu Ecclesiae (Ussher, 507); and they were enjoined at the Synods of Kells in I I 52 (Kciting, iii. 315) and Cashel in I 72 (Can. 3, Giralkus, Expug., i. 35). From the document quoted above we leam that in Oriel, under Donough O'Carroll, "tithes were received"-evidently a new impost.

6. "Ministers of the altar were exceeding few" in the diocese of Connor (\$ 16$)$; and accordingly it is observed that Malachy pro. vicled lis new churches with clergy (\$ I 7 ). This is not proved, nor is it in any great legree corroborated by the statement of A.F.M. (I 148 ) that Nalachy "ordained bi;hops and priests and men of every order"; but the parallel is perhaps worth noting.

7. The voice of the preacher was not hearl in the churehes (\$ I6). This statement cannot, so far as I know, be checked.

S. The same remark must be made alont the statements that the people would not come to church (\$ 16$)$, and that Malachy's excrtions at length incluced them to do so (\$17), though they are sufficiently probable.

9. That "churches were rebuilt" (\$ I 7 ) cannot lie questioned. No doult the monasteries of Bangor and Saul would be counted among the number. We have explicit and independent evidence of the fact. The foundation of churches and re-edifying of monasteries were a conspieuous feature of the reign of Donough O'Carroll (see p. 170). And A.F.M. ( $11_{4} 8$ ) lay great stress on Malachy's activities in this direction. He "consecrated many churches and cemeteries," and "founded churches and monasteries, for by him was repaired every church in treland which had been consigned to decay and neglect, and they had been neglected from time remote."

On the whole it appears that St. Bernard's strictures are at least not without foundation in fact, in so far as they can he tested. But he can searcely be aequitted of some measure of exaggeration in the rhetorical passages in which they occur. 


\section{B. - Tile Herrditary Succession of the Coarbs of PATRICK.}

\section{Life, $\$$ 19, 20, 30.}

The assertions of St. Bernard in $L i f_{\mathcal{c}}, \S \mathbf{1 9}$, concerning the coarlss of Patrick are controlled by $A . U$. The ninth predecessor of Cellach, Cathasach II. (†957) is described in them $(s . a .956)$ as " coarl of Patrick, learned lishop of the Goidhil." None of the following eight is said to have been a bishop, though all are called coarbs of P'atrick. Moreover Cellach himself was appointed abbot before he "received holy orders," and the record of his ordination on St. Adamnan's Day (September 23) 1105, several weeks after his " institution," seems to indicate that it was unusual for the abbots to be ordainel. All this corroborates the statement that his eight predecessors were "without orders." It is true, indeed, that according to A.F.M. Amalgaid, one of the eight, anointed Maelsechlainu king of Ireland, on his deathbed in 1022. But it does not follow from this that he was a priest. In early times, as is well known, unction was administered to the sick by laymen; and there appears to he no evidence that this office was confined to the priesthood till well on in the nintla century (Dict. of Christ. Antiquitzes, ii. 2004). It is at least possible that the older usage lingered on in Ireland to a much later date than on the Continent. But the statement of A.F.M. as to the anointing of Maelsechlainn is not confirmed by the more reliable authority of $A . U$.

That at least five of the eight were, as St. Bernard says, "married men" is slown by the following table, compiled from $\%$. and MacFirbis (K.I.A., MS. 23 I. I, p. 308). The persons whose names are printed in italics were coarbs of Patrick.

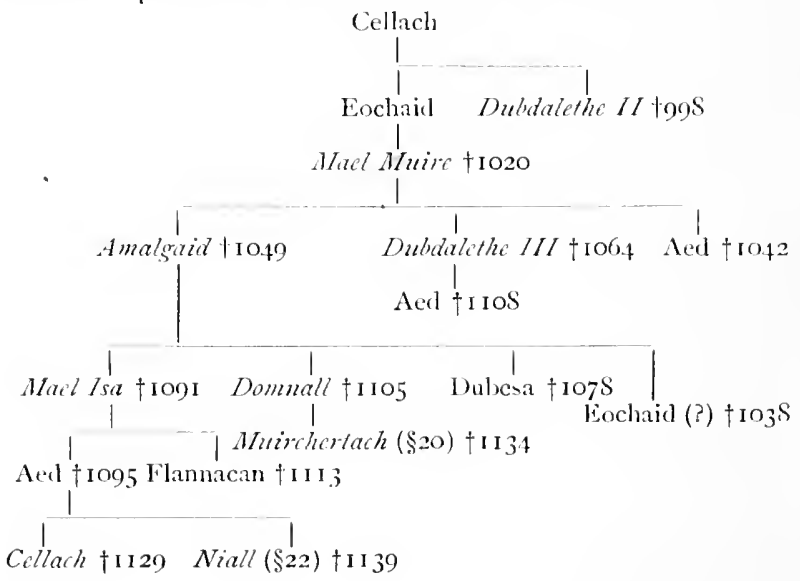


This table also confirms the statement that the abbots all belonged to the same family, and so obtained office by a sort of hereditary right. St. Bernard gives no hint which would enable us to identify this family. But the genealogy given by MacFirbis enumerates the ancestors of Cellach in a direet line up in Fiachrach, son of Colla fo Crich, and is headed "Genealogy of Ui Sinaich, i.e. the coarhs of Patrick." The Bodleian MS., Rawl. I. 502,' has the same genealogy, and entitles it "Genealogy of Clann Simaich." The family then from which the abbots of Armagh were taken was the principal branch of that sept. From the genealogy it appears that the sept was derived from Sinaeh, from whom the fifth in descent was the Cellach whose name appears at the head of foregoing table.

St. Bernard represents Malachy to have said in 1132 , when be was indueed to oppose Murtough, that the system of hereditary sucecssion had already lasted nearly two eenturies (\$20). This statement is in accord with known facts. The genealogical table gives sufficient evidence that it began not earlier than the accession of Dubdalethe II. (965), and eontinued to the accession of Murtough. If there is no evidence that the three predecessors of Dubdalethe were of the Clann Sinaich, neither is there anything to disprove it. But their immediate predccessor, Joseph, was certainly not of that sept; for $4 . U$. (MS. A, 935) tells us that he was of the Clann Ciairb-gaela, and the list of coarbs in the Bonk of Leinster notes in adlition that he eame from Dalriada (R.I.A. xxxv. 327, 359). Thus the succession eannot have been established before the death of Joseph (936). IIence it lastel for a period of between 167 and 196 years. A period of 167 years, or a period of 196 years, might he rlescribed as "well-nigh two hundred years" (annos ferme diccntos), though the latter suits St. Bernard's language better than the former.

But how can this be harmonized with the statement that "fifteen quasi-generations had passed in this wickedness" (\$ I 9$)$ ? Obviously a "quasi-generation" is not a greneration of human life : apart from the facts just mentioned, the very word quasi forbids the supposition. Colgan (Trias, $\mathrm{P} \cdot 3 \mathrm{OI}$ ) suggested that the word indicates the period of office of a coarb; and this is very probable. The figure of generations, so applied, is in line with st. Bernard's conception of a bishop as "the seed" of his predecessor (\$ 3.4). But the fust of a series of coarbs, of whieh Murtough was the fifteenth, was Maelcoba, the second predecessor of Joseph. So that, even on Colgan's hypothesis, St. Bernard's two statements are irreconcilable. Yet it is difficult to believe that an error so manifest was in his sonrce. I suggest that he wrote "fifteen" in error for "twelve" : in other words his document had $x i i$, and he misread it $x u$. The confusion of $u$ with $i t$ is very common in manuscripts. If this explanation is accepted, St. Jemard's authority implierl that the hereditary succession was upheld without interruption from the death

1 See Kuno Meyer's Facsimile edition, p. 146, e. The genealogy there hegins with $A$ maigaid, not witl Cellach. 
of Joseph to the accession of Murtough, which is "well-nigh two hundred years."

This investigation may convince us that St. Bernard depended on an excellent document for his knowledge of the history of Armagh. But he eertainly went astray in the interpretation of the document when he styled the predecessors of Cellaeh metropolitans (sce p. 45, n. I). And he goes further when he asserts that none were allowed to be bishops who were not of their family (\$ r9); thus leaving the impression that under the rule of the eight lay abbots - that is, for a century and a half-Armagh was deprived of episeopal ministrations. But this is wholly unhistorical. The Ulster Annals mention six bishops of Armagh, eontemporary with the lay abbots. They seem to have followed one another in regular succession, and there is no indication that any one of them belonged to the Clann Sinaich. They were no doubt monastic bishops, such as are found in the Irish Church from the sixth century onwards, who exercised the functions of their order at the bilding of the abbots. They were probably not referred to in St. Bernard's document; and if they were, one who had been trained in an entirely different ecclesiastical system would have been at a loss to understand their position.

Thus we eonclude that St. Bernard, in the passage which we are considering, used grood material with conscientious eare, but that he was misled by laek of knowledge of Irish eeelesiastical methods. This result is important beeause it may apparently be applied to the whole of his memoir of St. Malachy. II is statements, as a rule, stand well the test of comparison with the native records; and when he is at fault we can usually explain his errors as misunderstandings, due to ignorance of conditions of which he had no experience.

St. Bemard has been eharged with gross exaggeration in another passage. "A great miracle to-day," he writes $(\$ 30)$, " is the extinction of that generation, so quiekly wrouglit, especialiy for those who knew their pride and power." It is an extravagant hyperbole to say that either the O'Neills, or the great tribe of the Oirgialla, represented to this day by the Maguires, the O'Hanlons and the MacMahons, was blotted out when the Life of St. MIalachy' was written. So argued some in the time of Colgan (Trias, p. 302). But they misrepresented St. Bernard. The word "generation" obviously means in the sentence before us what it meant in $\S$ I9 ("adulterous generation") - not an extensive tribe, nor even the Clann Sinaich as a whole, but the branch of that sept which provided abbots for Armagh. The speedy extinction of a single family is not a thing ineredible. And it is worthy of remark that neither the Clann Sinaich, nor any person cleseribed as ua Sinaich or mac Sinaich is mentioned in the Annals after I I 35 (see p. $5 \delta$, n. 9).

For a more detailed treatment of the subjects diseussed in this note reference may be made to K.I.A. xxxv. 232-23\&, 340-353. 


\section{C. - Malacily's Contest with Niall. \\ Life, §§ 22-3I.}

The narrative of the series of events between the death of Murtough and the consecration of Gelasius, both in Sit. Bernard's Life and in A.F.M., is olscure, and our two main anthorities contradict each other in some particulars. In this note I propose to attempt a reconst ruction of the story.

I. Among the native authorities A.F.M. stand alone in giving what approximates to a full account of the struggle letween the rival abbots. A.T. record only three incielents; the Chronicon Scotorum also records three incidents belonging to the year i I 3 , and then breaks off, to be resumerl in 1142 ; in $A . L$. and $A . I$ there are hia!us which cover the whole period; the other Annals ignore the events wilh which we are concernerl. The information supplied by A.F.M. runs as follows:

1134. (I) Malachy O'Morgair made a visitation of Munster and obtained his tribute.

(2) 1 chapel, which was crected by Cormac Mac Carthy, king of Cashel, was consecrated hy a synod of clergy assembled at that place.

(3) Wurtough dierl i 7 September.

(4) Niall was installed in the crarbate of Patrick.

(5) A change of abbots at Amagh, i.e. Malachy o'Morgair in place of Niall.

(6) Malachy afterwards made a visitation of Munster and reccived his tribute.

I 35. (7) Flann Ua Sinaich, keeper of the Staff of Jesus, died after good penance.

(8) Malachy O'Norgair purchased the Staff of Jesus, and took it from its cave 7 July.

I $3^{6 .}$ (9) A visitation of Munster was made by Malachy O'Morgair, coarb of Patrick.

(Io) A change of abbots at Armagh, i.e. Niall in place of Malachy.

(I I) Malachy O'Norgair resigned the coarlmate of Patrick for the sake of Crod.

1137. (12) A change of abbots at Armagli, i.e. the erenach (recte alhot) of Derry in place of Niall.

I $3^{3}$. ( I3) Christian O'Morgair died.

$A . T$. record the second and fifth of the above cvents, and subjoin 
to the latter notice the passage quoted p. 5I, n. 4. The Chronion Scotontum records the second, third and fifth.

There is obvious confusion in the narrative of the Masters. They put the death of Christian O'Morgair under $\operatorname{I}_{3} S$, which is a year too early (see p. 66, n. 1), and they credit Malachy with having made three visitations of Munster within three years, which he is very unlikely to have done. But it is 10 be observal that the notices of the visitations are not mere repetitions, for they differ from each other verlally. Thus we may suspect that the Masters copied those entries from three different sonrces, ant that they refer to the same visitation, which, in at least one of the sources, appeared under the wrong year. Now the consecutive sentences 9, to are probably connecterl with each other: the absence of Malachy in Munster would give his opponents opportunity to reinstate his rival. In like manner entries I, 2 (not consecutive) may be connected. It would not he surprising if Malachy, even at some risk to the security of his tenure of the abbacy at Armagh, took part in the consecration of his patron's chureh at Cashel. And it may be adder that he would not improtuably make this visit to the south the occasion of a circuit in Nunster. The visitation, on that lypothesis, must have taken place in 1134 or early in II 35. Again, the note of time in cntry 6 implies that it was made not very long after the appointment of Malachy, reeorded in the immediately preceding entry 5 . Firially, entry $S$ mentions an event which must have greatly strengththerl his hands. IIaving possessed himsclf of the more important and revered of the abliatial insionia he was at length more than a match for his antagonist. Probably, therefore, the restoration of Niall (10) should be placed rather before than after it. For these reasons we seem to be justified in placing the recorded incidents in the following orler. When Malachy secured possession of the see (5) he remained long enough in Armagh to establish himself in the ablacy. During this time may have occurred the abortive conspiracy against him related in $A . T$, but not alluded to in $A . F . M$. IIe then went to Cashel for the consecration of the Chapel (2), and held his visitation of Munster $(1,6,9)$. When be returned he found that Niall had once more entered Armagh (10). By July 1135 the power of his rival had considerably decreased, and Malachy got possession of the Staff of Jesus (S). Finally he resigned his office (II) and Gelasius was appointed to it (12). If this is a true account of the course of cvents, one statement of the Annals needs correction. They tell us that Gelasius succeeded Niall; on onr hypothesis he succeeded Mlalachy. But that the Masters should have substituted the former for the latter was to be expected ; for according to their provious (as I believe misplaced) statement Niall, not Malachy, was in possession in the latter part of 1136 .

2. We now turn to St. Wernard's narrative of these transactions. Sections 22 and 23 present no difficulty. 'They are simply an amplilication, with differences in detail, of what we lean from A.T. In the early part of $\$ 24$ it is stated that Malachy rcmained in Armagh after the king, with whose aid he had "ascended the chair 
of Patrick," had returned home ; and in the succeeding narrative it is implied that he never left it till he went to Down. That is to say, the visitation of Munster is ignored. This need cause no surprise. It is quite possible that St. Bernard had never heard of it. Again, there is no explicit nention of the reinstatement of Niall. But it seems to be implied in $\$ 24$ (see p. 53, 11. 9). The whole story becomes more intelligille if we assume that Niall was in possession for a short time, and then fled, but continted to exercise his functions outside the city, as Malachy hinself had done in a previous period $(\$ 2 I)$. If we suppose that the visit to Munster took place shortly after the episode of $\$ 23$ we can explain the only difficulty in the narrative, the return of Niall after he had been driven out. The latter part of $\$ 2.4$ seems to intimate a lessening of opposition to Nalachy's rule. The whole passage, $\$ \$ 24-27$, with the exception of the last two sentence; of $\$ 27$, mut relate to the period lefore July I 135 , inasmuch as Niall is represented as carrying about with him the Staff of Jesus as well as the Book of Armagh.

Up to this point St. Bernard's narrative harmonizes admirahly with the story as it has been reconstructerl above from the Annals. liut we must carry our comparison of the two accounts a little further. They agree in giving i 37 as the date of the appointment of Gelasius as coarb of Patrick; lut while St. Bernard puts the resignation of Malachy in the same year the Masters recorl it under 1136 (p. 6I, n. 7). Now their phrase (I I), that he "resigned for the sake of Gorl," in its present context (Io) can have only one meaning. Nalachy, seeing that his contest with Niall was lupeless, determined to retire rather than continue the strife, and left Niall in possession. But apart from entry 10, which seems to have been misplaced, the words have no such implication, and are in liammony with the reason given by St. Bernard for Malachy's return to his former diocese $(\$ \$ 20,21)$. Since the dates of the Masters for this period are already suspect we need not hesitate to follow St. liernard's guidance here. But we may go further. The annalists were compelled, if they would be consistent, to suppose that there was a considerable interval between the retirement of Nalachy and the accersion of Gelasius. How was it possible that when Niall had finally routed his formidable rival, who was in poseession of the Staff of Jesus, another should at once step in and, apparently without any difficulty, deprive him of the frnits of his victory? The difficulty is increased if we accept the statement of St. Bernarinot contradicted by the Annals, and not easy to dispute - that Gelasius was nominated by Malachy himself, and was therefore presumably favourable to his cause. Thus we perceive that there was good reason that the annalists should separate the two events as far as possible, by antedating Malachy's resignation, and by connecting it rather with Niall's restoration than with the appointment of Gelasius.

3. In weighing the respective claims of St. Bernard and the annalists to credence in this part of Malachy's life it is well to remember that of it St. Hernard may be assumed to have had full and firsthand information. The main facts were probalsly communicaterl 
to him by Malachy himself, though some particulars were no doubt added by other Irish informants. It is true, we must also allow for bias on St. Bernard's part in favour of his friend. Such bias in fact displays itself in $\$ \$ 25,26$. But bias, apart from sheer dishonesty, could not distort the whole narrative, as it certainly must have been distorted in the Life, if the narrative of $A . F . M$. is to be accepted as it stands.

4. It is important to observe that in the carlier stages of Malachy's conflict with Niall the lord of Oriel was Conor O'Loughlin, who was apparently not friendly to the reformers of the Irish Church (cp. $\$ \$$ I 8,20, p. 40, n. 2 , and p. 46, n. 5). No doubt his defeat by O'Brien and Mac Carthy in 1134 (p. 43, n. 5) made him a less ardent supporter of Niall than he had been of Murtough; but it is not likely that he entircly discouraged his attempts to seize the abbacy. The ultimate success of Malachy was in fact prooably due to O'Loughlin's murder at the end of May $I$ I 36 and the rise to powes of I onough O'Carroll (see p. $5^{8}$, n. I I), his successor in the kinglom of Oriel. St. Bernard never mentions O'Carroll by name, though he possibly alludes to him in one passage ( $\$ 2 S$ : see note there). But we may infer from other sources that lie was a zealous friend and helper of Malachy. The most important of these is a contemporary document, part of which has licen copied on a blank page of a fourteenth-century Antiphonary of Amagh (T.C.D. Ms. Ii. 1. 1.) opposite the first page of the Calendar. Unfortunately the scribe laid down his pen at the end of a line and in the middlic of a sentence. The document was first published by Petrie (p. $3 \mathrm{~S} 9$ ) with a Iranslation. As it is referred to several times in the notes to the Life it may be well to print here, with a few slight alterations, Dr. Whitlcy Stokes' revised rendering (Gorman, p. xx.).

"Kalend. Januur. v feria, lun. x. Anno Domini maxx. A prayer for Donnchad Ua Cerbhaill, supreme King of Oirgialla, by whom were made the book of Cnoc na nApstal at Louth and the chiel books of the order of the year, and the chief books of the Mass. It is this illustrious king who founded the entire monastery both [as to] stone and wood, and gave territory and land to it for the prosperity of his soul in honour of Paul and Peter. By him the church throughout the land of Oirgialla was reformed, and a regular bishopric was made, and the church was placed under the jurisdiction of the bishop. In his time tithes were received and marriage was assented to, and churches were founded and temples and bell-honses [round towcrs] were made, and monasteries of monks and canons and nuns were re-edified, and nemheds were made. These are especially the works which he performed for the prosperity [of his soul] and reign in the land of Oirgialla, namely, the monastery of monks on the lanks of the Poyne [as to] stone and wood, implements and books, and territory and land, in which there are one hundred monks and three hundred conventuals, and the monastery of canons of Termann Feichin, and the monastery of nuns, and the great church of Termann Feichin, and the church of Lepadh Feichin, and the church of . . ." 
O'Carroll, then, was an ardent supporter of Malachy. Is it likely that after his long struggle to secure the Chair of Patrick, and when he was in actual possession of it, Malachy should voluntarily surrender his claim to Niall at the very moment when the new king of Oriel had come to his aid? Y'et, unless we are prepared to place his resignation before June I 136 , that is the assumption we must make if we adhere to the statements of A.F.MI.

5. There are other documents of high authority which must be taken into account : the contemporary record of the succession of coarbs of Patrick in the Book of Leinster, and the copy of a similar record in the Yellow Book of Lecan. The former of these seems to have been written by a partizan of Malachy, since it ignores Murtough. The latter assigns to that abbot a rule of three years, in agreement with St. Bernard ( $\$ \$ 20,2 \mathrm{I})$. liut neither of them so much as mentions Niall ; and both make Gelasius the successor of Malachy. Thus they contradict A.F.M. and corroborate the narrative of St. Bernard. See R.I.A. xxxv. 355 f.

\section{APPENDIX.}

The Portion of $\$ 4$ I OF the Life omitted in Translation.

Alla quaedam ibidem pernotabat in oratione, ${ }^{1}$ yuam forte reperiens solam homo barbarus, accensus libidine et sui minime compos, irruit rabiosus in eam. Conuersa illa et tremefacta, suspiciens aduertit hominem plenum dialolico spiritu. "IIeu," inquit, "miser, quid agis? Considera ubi es, reuerere haec sancta, defer Deo, defer seruo eius Nalachie, parce et tibi ipsi." Non destitit ille, furiis agitatus iniquis. ${ }^{2}$ Et ecce (quod horribile dictu est) uenenatum et tumioum animal quod bufonem uocant uisum est reptans exire de inter femora mulieris. Quid plura? Terrefact us resiliit homo, et datis saltibus festinus oratorio exsilit. Ille confusus abscessit, et illa intacta remansit, magno quidem et Dei miraculo et merito Malachiae. Et pulchre operi foedo et abominando foedum interuenit et abominabile monstrum. Non prorsus aliter decuit bestialem extingui libidinem quam per frigidissimum uermem, nec aliter temerarium frenari ausum frustraii conatum quam per uilem inutilemque bestiolam.

1 l.uke vi. I2.

2 In hexameter rhythm. Cp. Virg., Acn. iii. $33^{\mathrm{I}}$; Ov., Art. Am. ii. 27. 


\section{INDEX}

ABELARI, IOI

Acoemetae, 30

Adeline, 69

Agre for ordination, $15 \mathrm{f}$.

Agnew, Sir Andrew, $7 \mathrm{~S}$

Aidan, St., liv

Ailech, 40

Aleth, mother of St. Bernard, 7,71

Mexander I., king of Scots, 76

$\mathrm{Al}_{\mathrm{p}}, 72$

passes of, when closed, 142

Alternative sees, $x$ liii, I 9

Amalgaid, coarb of Patrick, 164 , 165

Anacletus II., anti-pope, 72

Anastasius, St., monastery of, at Rome, i 18

Annchara, I6 I

Anselm, archbishop of Canterbury, xv, xxii, xxiv, xxvi, xxxvi, 47, 162

letters of, xxiv, sxix, xlvi, 47

Antiphonary of Armatsh, 170

- — of Bangror, $2 \mathrm{~S}$

Antrim, SS

Applecross, 29

Arch-priests, xxvii

Ardnurcher, diocese of, li

Ardpatrick, 14

Ards, The, yo

Ardstraw, diocese of, xli

Argyll, diocese of, $2 S$

Armagh, xvi, xvii, lvii, S, II, $26,3^{6}$

abbots of, 164: sec also

Amalgaid, Cathasach,

Donnell, Dnludalethe, Joseph, Mael Brigte,

Maelcoba, Maelisa,

Murtough, Niall antiphonary of, 170 .

archbishops of : sec Cellach Gelesius, Nalachy

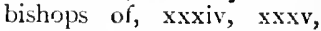
$\mathrm{I} 64,166$

Book of, 53 f., 5\$, 169

cemetery of St. Patrick at, I 5

diocese of, xli, lvi, lviii, $16 \mathrm{I}-163$

insignia of abbots of, 53-5, $58,16 S, 169$

monastery of SS. P'aul and Peter at, I I, IS

pestilence at, 60

Aube, river, 7 I

Augustine, St., archbishop of Canterbury, xxxix

Augustinian canons, $1 x, 1 \mathrm{I}, 63$, $64,67,69,113,121$

baltinglas, 76

Bangor, liii, liv, lv, lvii, lviii, $\mathrm{lx}, 26,27,36,67$, So, $11 \mathrm{~S}$

abbey church at, 109

abbots of, liv, 2S, 31: sce also

Tanaidhe

ancient glory of $27-30,74$

antiphonary of, $2 \mathrm{~S}$

called Vallis Angelorum,

27

community of, $\mathrm{lv}, 4 \mathrm{I}$

convent of regular cleric; at, $63 f$.

etymology of, 27

head-quarters of St.

Malachy, liv, lviii, 33. $35,64,113$

monastery of, $2 \mathrm{~S}, 91 \mathrm{f}, 9^{6}$, 104,163

canons of, formed thic bishop's cluapter, 64 
Bangor monastery-

destroyed, 30,40

oratory of, 30, 32, I09-

113

possessions of, 26, 3of., IOS, III

remains of, 109

site of, $2 S$

Bann, river, xli, xliv

Bar-sur-Aube, 7 I

Barre, St., lxi, 92

Barrenness of soul, 98

Beatitudine, De, 76

Bective, 76

Bede's History, xxiii, xxxix f.

Bedell, Bishop Willian, xvii

Benedictione Dei, De, 76

Berengarius, IoI

Bernard, St., xv, xxxv, lx, lxii, $1 x v, 7,16,71,72,117$

at St. Malachy's funeral, I 29 bias of, I7O

errors of, 19, $31,35,36$ f., $40,45,46,50,53,62$, $63,76,92$, I IS. I22, I 24 , $165,166,169$

frailty of, I 22

kisses St. Malachy's feet, I29, I44

omissions of, 53, 87 , I 69 , 170

used good materials, I66

Bernard, Great St., nountain, $7 \mathrm{I}, 72$

Little St., mountain, 72

lishop of a diocese abbot of regular canons, 64

"Bishop-King," 44

IBishops in Ireland, number of, xliii, 1 xii, 46

status of, xiii f., xxxiii, I 66

Bobbio, 29

Book of Armagh, 53 f., 5\$, I69

Book of Kells, xxv

Book of Leinster, I I I

Borromeo, St. Charles, favoun ite story of, 96

lioyle, 76

Boyne rive1, 75, 170

bregha, to
Breifne, xlix

brian Boroimhe, xxiii, I61

Brigit, St., Ioo

Brothers left at Clairvaux by St. Malachy, 4, 68, 74, I32

- sent from Ireland to Clairvaux, $75,13 \mathrm{I}$

- sent from Clairvaux to

Ireland, 75, I33, I35

Brude, king of the l'icts, 29

Brus, Robert de, I 21

Burial of the poor, It

Cairngarroch, 67,78

Canice, St., 29

Canon of Patrick, 54

Canonical hour's, chanting of, $17 \mathrm{f}, 37,161$

Canterbury, xxxix, 70

archlishops of: Sée Anselm, Augustine, Lanfranc, Ralph, Sigeric, Theolald

suffragans of, xxi, xxii, xxxvi, $\mathrm{xly}, \mathrm{xiv}$

Carlisle, 64, 67, 76

Carntougher mountains, xli, xliii

Carthach, St., I9

Cashel, 65, 9 I

archbishop of : see Malchus

archbishopric of, xxxvf., xlvii, Ixi, Ixiii, 65,73

assembly at, $\mathrm{xxxy}$ synod of, 62, 75, 163

Cathair, $4^{\circ}$

Cathasach, abbot and bishop, of Armagh, I 64

Catholicus, a brother, I I9

Ceadd, lv

Cedd, lv

Cellach, archbishop of Armagh, xxii, xxxiv-xxxvii, xxxviii, xlvi, lii, lv, lvi, lvii, lx, I4, I5, $16,20,26,36,40,43,45$, $46,49,65,89,164$

not married, 49

"wife" of, 49

will of, lvi, 43,47

Cenél Conaill, xliii

Cenél Eoghain, xliii, 59

of the Island, xliii 
Christian (Gilla Crist Ua Condoirche), abbot of Mellifont, bishop of Lismore, papal legate, lxii, lxv, 34, 75, 95, I 34,136

bishop of Clogher; see O'Norgair

Church of Ireland, constitution of, xiii-xy

Church 1sland, to f.

Churches founded, I 70

Ciaran, St., xlix

Cistercian Order, $1 x, 4,69,7 \mathrm{I}$, $76,114,120,136$

churches of, IO9

Citeaux, 71

"City," 35, 37, 40, $85,8 \$$

Clairvaux, 1x, Ixti, 71, 73,74, 75 , IIS

brothers left at, by St. Nalachy, 4, 68, 74, 132 brothers of, return to, 75 , I 35,136

brothers sent to, from Ireland, $75, \mathbf{I}_{j} \mathrm{I}$

brothers sent from, to

Ireland, 75, I33, I35

monks of, unwilling to leave it, 136

oratory at, I2S, I 29

St. Malachy's wish to die at, 72, 117, I21, I24, I $2 S, 143$

second monastery of, 7 I, I43

Clann Gaurl-gaela, 165

Sinaich, 46, I65 I66

Clergy, dearth of, $37,39,163$

Clogher, diocese of, Iv lii- $\mathrm{Ix}$ barony of, lix

bishops of: see G'lboyle,

O'Morgair

church of, 54

Clonard, bishops of : see Eugenius, O'Dunan, kochfort

diocese and see of, $x x v$, xxvii, xxix, slix, 1

Clonenagh, annals of, xxxviif., Ixii, lxiii

Clonmacnoise, xvi

diocese of, xxviii, xxix, xlix, li
Clontarf, battle of, xvi, xix

Clova, 28

Cloyne, SS diocese of, 1xi

Cluain uama, 88

Coarb, meaning of, xiii authority of, derived from founder of his church, 44

Coarbs of Patrick, I06, 164-6: see also Armagh, abbots, arch. bishops

married and without orders, 45,164

Coleraine, $\mathrm{S}_{5}$

Columba, St., 29

Columbanus, St., 29

Comgali, St., 28, 29, 74

coarb of, 27 : see also O'Gorman, O'Hanratty

relics of, 30

Communities founded by St. Nalachy, 31, 75, $8_{3}$, I I3, I 37

Conall Gulban, 7

Confession, I\$, 37, 39, S8, 98 , I6I

Confessors, I6I

Confirmation, I8, I9, I62

Congan, abbot of Inislounaght, $4, \mathrm{II}_{4}$

Connaught, 44,93

Connor, $35,37,40,62,63$

diocese of, xli, lviı, lviii, lxii

Connor or Down, diocese of, xli, xliv, xlvii, liv, lvii, Iviii, Ixii, $36,48,49,62$ f., I6I-3 division of, lvij f., 62 f. see of, liv, 35

Conuama, 88

Conversion, I I, 82

Conversus, 34

Cork, 21, 92 abbey of St. John Evangelist at, 93

bishop of : see Ua Muidhin diocese of, Ixi, 92 election of bishop of, 92-4

Cormac: see Mac Carthy

Cormac's chapẹl, 44, 5i, 167, I68 
Cruggleton, 76 f., 78

Cuthbert, St., 69

Daimliac mór at Armagh, II

Dairtheach, 32

Dál Araide, lvii f., 40

Dalriada, 165

Danes in Ireland, xiv ff.

Danish colonies in Ireland, xix

_ dioceses, xxvi, lxiv

ruled by Irish bishops, $\mathrm{xx}$, $\mathrm{xxi}$

Dates discussed :

appoint ment of St. Malachy as vicar of Ceilach, I6

birth of St. Malachy, i 30

building of stone oratory at Bangor, 109

composition of Life of St. Mlalachy, $1 \mathrm{x} v$

condemnation of heretic at Lismore, 102

death of Christian O'Morgair, 66

departure of St. Malachy from England (1 148 ), 123

election of bishop of Cork, 93 foundation of Inislounaght, I 4

journeys of St. Malachy, 7I, 73

letters of St. Bernard, I3I, I 33, I 34, I 37

ordination of St. Malachy, I6 proposal of St. Malachy to visit Rome, 72

resignation of Gilbert, bishop of Limerick, 73

resignation of see of Armagh by St. Malachy, 61, 169

St. Malachy's instruction under Imar, II

St. Malachy's visits to Lismore, $20 f$.

sermons of St. Bernard, I4I, 152

visit of St. Malachy to York, 7o

visitation of Munster by St. Malachy, $16 \mathrm{~S}$
David I., king of Scots, $76 \mathrm{f}$. 120, 121

Dermot, the connt: sec Mac Murrough

_- father of Gelasius, 62

- father of St. Malachy, 6

Derry, diocese of, xli, xliv, Iviii

Erenach (abbot) of: sec Gelasius

xlvii

Desmond, 21, 43; sce also Mac Carthy

De Statu Ecclesiac, xxx-xxxiii

Dijon, 30, $7 \mathrm{I}$

Dioceses of Scotland, 76

Domnach Airgid, 54

Donnell, abbot of Armagh, xxxiv

- bishop, xxiii, xxiv

Dove enters church, I1 5

Dove-like eyes, $6_{3}$

Dover, 70

Down, diocese of, xli, Iviii, lxii see of, Iviii, 64

Downpatrick (I)own), $3^{6}, 44$, 62,63

dispute between prior and monks of, and abbot and canons of Bangor, 64 monastery of Irish at, 63

Dromore, diocese of, xxii, xli

Dubdalethe, II., coarb of I'at rick, I 64,165

Dublin, xix, xlvi

archbishopric of, lxiii f.

archbishops of: see Gregory, O'Toole

bishops of, $\mathrm{xx}$, xxiii : see also

Dunan, Gregory, O'IIanley,

Patrick

burgesses of, xxii, xlvi

church of Holy Trinity (Christ

Church) in, xix, 54, 64

liocese of xix, xiv

hostility of, to Irish Church, xxii, xlvf., Ixiiif.

king of: sic Gotluric, Sitric

Ducziniu, SS 
Dilleek, xlix diocese of, 1

Dunan, bishop of Dublin, xix, $\mathrm{xx}$

Dunshaughlin, diocese of, xxvii, i

\section{Ecclesia, 4}

Edgar the Atheling, 76

Fmly, diocese of, lxi

Eporedia, 72

Erming Street, 70

Erne water-way, lix

Erolbh, bishop of Limerick, xxi

Errew, 93

Espec, Valter, 69

Eucharist called "sacraments," I 4

heresy concerning, $\mathrm{IOI}_{-3} 3$

Eugenius III., Pope, lxii, lxv, 3 , 38, II 7 f., 122 bishop of Clonard, 1

Eusebius, a deacon, I4

Family of coarbs of Patrick, 165 extinction of, 6I, 166

"Fasting on," 106, 107

Faughart, I0o

Fearnmaigh (Farney), 59

Felix, bishop of Lismore, 75

Ferdomnach, 53

Fergus, lord of Galloway, 77, I 20

Fer légind, xvi

Fermanagh, lix

Ferta martair, I 5

Fiachrach, son of Colla fo Crich, I 65

Fiadh meic Oengusa, council of, xxxvii, 46

Fingal, 59

Finnian, St., xlix

Fir Li, xliv

Fontaines, 71

Fore, diocese of, li

Forma, II, 56

Four Masters, confusion of, I6S

Gall, St., 86

Gelasius, archbishop of Armagh, lvii, $1 x$, lxiii, 59, 62, І67, I68, I $69, \mathrm{I} 7 \mathrm{I}$

" (ieneration," 45, 166

Gentes, 74, So

Geoffrey, St. Bernard's secretary, $47,8 \mathrm{I}$

prayer of, I 30

Gerlatus, 8 I

Geswalt, 78

Gibeonites, 50

Gilbert, bishop of Limerick, papal legate, xxi, xxii, xxvi, xxix-xxxiii, xxxiv, xxxv, xxxvi, xxxvi, xxxviii, xliii, xlivf., xlviii, lvi, lx, lxi, I7, 47 f., 73,163 ; noi a suffragan of Canterbury, xxi f., 47

-_-, St., of Sempringham, I 23

Gill Abbey, Cork, 93

Giraldus Cambrensis, xv, I62

Gisburn, 67, 121

monastery of, $\mathrm{I} 2 \mathrm{f}$.

Glendalough, bishop of, xlvi, lxiv

diocese of $\mathbf{x l v}$, lxiv

Godscalcus, $\mathrm{SI}_{\mathrm{I}}$

Gothric, king of Dublin, xxiii

Gougaud, Dom L., xxi, 76

Gregory, archbishop of Dublin, $\mathrm{xx}, \mathrm{xxii}, \mathrm{xjii}, 20$

- I., Pope, xxxix, xl VII., Pope, I62

Greenogne, xlv

Grenan Ely, 40

Gyrovagus, 55

llarding, Stephell, $7 \mathrm{I}$

Ienry I., king of England, 47

- II., king of England, 62

—, son of David I., king of Scots, 77

Hereditary succession of abbots, $\mathrm{xv}$, lvi f., $45 \mathrm{f.}, 48,148,165$

Heresy regarding the Euclarist, IOI-IO3

Linba, 29

Holy Island, liv

Trinity, churcl of : see Dublin

Ifonorius 11,, Pope, 72 
Hook, simile of a, applied to Death of Christ, $1+5$

IIorse presented to St. Malitchy, $69 \mathrm{f}$.

HIumbert of Igny, 136

Ignatius, St., epistles of, 37

Igny, Humbert of, I 36

Imar : see O'Ilagan

Indrechtach, abbot of bangor, $3 \mathrm{I}$

Inishowen, xli, xlii f.

Inislounaght, 76, 1 I4

Inispatrick, synod of, lxi, I $1 S$

Imocent II., Pope, Ixf., 7I, $72 \mathrm{f}$, II 7 , IIS

Irish Church, state of, described, I6-I $S, 37$ f., 45 f., I 6 I-3

Isaac, $133 \mathrm{f}$.

Ithael, $x$ vii

Iveagl, 40

Iverigh, lv, 40, 43

site of S. Malachy's monastery in $40 \mathrm{f}$.

Ivrea, 7 I, 72

John Evangelist, St., Abbey of, at Cork, 93

-_._, son of Sulien, xvii manuscript written by, xviii verses, of, xviii

Jonas, 30

Joseph, coarb of Patrick, $165 \mathrm{f}$.

Judas Maccabaus, 23

Kells, xvii archdeacon of : see Petit archdeaconry of, xxviii bishop of, xxviii, lxiii look of, $\mathrm{xxv}$ diocese of, xxvii, xxviii, li synod of, xxvii, Ixii-lxiv, 75 , 93,163

Kilcurry River, I00

Kildare, xvii

Killeshin, 4

Kilmore, diocese of, xlix, li, lxii

Kingarth, 29

Kirkham Abbey, 69
Kirk Mochrum, $7 \unlhd$

Knock, monastery of SS. Paul and Peter at, 67, ins, i7o

Krusch, Bruno, $3^{3}$

Lambay lsland, xlv

Lanfranc, archbishop of Canterbury, $x v$, xxi, xxiii, xxiv, xxvi, I62; letters of, xxiii

Lapasperi, L'ortus, $78 \mathrm{f}$.

Larne, Iviii

Laurence, St. : sie O'Toole

Learning in Ireland, xiv, xvixviii, xxvi

Leath Chuinn, xxv, $\mathrm{xl}$

- Mogha, xl

Lecan, Yellow book of, I 7 I

Leinster, xxxviii, xl, S6

Book of, I 7 I

Lepadh Feichin, I 70

Lía na righ, $5 \mathbf{I}$

Limerick, bishops of : see Erolb], Gilbert, Patrick, Turgesius church of St. Mary in, xxx, xliv

diocese of, $x i x, x x i, x x x$, xliv

Lismore, xlvii, liii, Iv, I9, $3^{6}$, $46,69,86,87$, I 1 assemblies at, IOI $\mathrm{f}$. bishops of: sec Christian, Felix, Malchus

- or Waterford, diocese of, xlvii

in Scotland, 28

Llanbadarn Fawr, school of, xvii

London, 70

Lonth, see of diocese of Oriel, lix, 66

county of, lix f.

diocese of, lix, 64

bishops of: see O'Kelly, O'Morgair

moniastery of St. Mary at, 67

Loxewdy, diocese of, li

Lucius II., Pope, I IS

Lugaid, 28, 29

Lugidus, $2 S$ 
Luxeuil (Luxovium) $29 \mathrm{f}$.

Mabillon, J., lxv

Mac Cairthinn, St., 54

Nac Carthy, Cormac, king of

Desmond, liii, lvi f., 43 f., 5 I,

$53,93,167,170$

assists St. Malachy at

Iveragh, Iv, 40, 41

called Bishop-King, 44

character of, 22, 23 f., 44

crozier of, 44

expelled from kingdom and restored, lv, 2I-4, 4I, 43

Dermot, 93

Donough, lv, 21, 23

Teague, king of Desmond, $2 \mathrm{I}, 43$

Mac Firbis, 7, 164, 165

Mac Mahon, 166

Mac Murrough, Dermot, king of Leinster, 90

Mac Sinaich, I 66

Macl Brigte (Marianus Scotus), $\mathrm{x}$ viii

\section{of I'atrick, 7}

Maclcoba, coarb of Patrick, 165

Maelisa, abbot of Armagh, I 4

Maelsechlainn, king of Ireland, I6I, 164

Nagh Cobha, 40

Naghera, 44, 64

Magheramorne, 28

Mainz, xviii

Malachy, St., early life of, lii, 6-18

part taken by, in Reformation, lii-lxiv

vicar of Cellach, lii, I6-I\$, 20,163

at Lismore, liii, $1 \mathrm{v}, \mathrm{I} \&-26$, $40,86,87$, IOI-3

bishop of Connor, liv, 36-9, I 28

abbot of 13angor, 27, 4I, 43 , So, II 2

at Iveragh, Iv, 40-2

archbishop of Armagh, lvi f., lix, 53-6I bishop of Down, lvii f., lxi, $62 \mathrm{ff} ., \mathrm{S}_{2}$

journey of, to Rome, Ix f., 64-So

at Clairvaux, $1 \mathrm{x}, 70-2,74$, I 22-30

at Rome, 72-4

papal legate, lxi, 73, So f., $93,102, I_{32}$

last journey of, lxi f., IIS22,142

death of, lxii, 4, 117, I22, I $23^{-S}$, I 39 , I 4 I, I 4 3

burial of, $3,128-30,139$,

I 42, I 44

a canon of St. Augustine, I I age of, $12 S$

called an ape, i I I

character of, $3,7-10,47$,

$\mathrm{SI}_{\mathrm{I}-4}, \mathrm{I} 53-7$

coarb of Patrick, S2, 106

compared to Ananias of

Damascus, $\operatorname{loS}$

to Elijab, 52, 15I 159

to Elisha, 60, 95, I 29

to Moses, 159

to St. John Baptist, Sg

consecrated bishop, 36, 43

conspiracy against, by men

of Tullaghoge, 51, 57, I 68

contest of, for the abbacy of Arnagh, 46-61, I67$7 \mathrm{I}$

convent of regular clerics founded by, $63 \mathrm{f}$.

father of, 6

in Paradise, $\$ 9$

last sayings of, 123,124 , I $26,127,143,147$

letters of, to St. Bernard, I3I, I 35

made deacon, $14,15, I 6,43$ meaning of name of, 27 . I 57

miracles of, 32, 34, 52, 72, $77,78,79, S_{1}, S_{5}-10 S$, II1, I16, II9, I21, I29, I 54, I $5 \mathrm{~S}, \mathrm{I} 7 \mathrm{I}$

monastery of, is, 104 
Malachy, St.-

mother of, $7,8,27,162$

not allowed to cross channel, I 2 I 142

ordained priest, I5, 16, 43

parents of, 6

plot against, by a prince at

Armagh, 55-7

reason of retirement of,

from archbishopric, I69

rebuilds churches, 39,163

reforms of, $\mathrm{I} 7 \mathrm{f} ., 39,5 \mathrm{~S}, 6 \mathrm{I}$,

$8 \mathbf{1}, 163$

relics of, 73,130

sister of, I4, I $5,25 \mathrm{f}$.

uncle of, 27

visions of, 25,49, I I 3

voluntary poverty of, 49,

82, 149

where buried, I 30

Malchus (Mael Isa $\mathrm{Ua}$ hAinmire), bishop of Waterford, archbishop of Cashel, $\mathrm{xxi}$, xxii, xxiv, xxv, xxvi, xxxiv, xxxvi, xxxviii, xlvi, xlvii, liii, lv, lx, IS f., 2 I, 23, 47 f., 65 ; miracles of, $19 \mathrm{f}$.

-, brother of Christian, abbot of Mellifont, $33 \mathrm{f}$., 95

Malcolm IV., king of Scots, 77 Canmore, king of Scots, 76

Marcus, author of Tundale's Vision, 88

Margaret, St., 76

Marianus Scotus: see Mael Brigte, Muiredach.

Marriage, I8, 37, 39, I62, I 70

Married abbots of Armagh, 45, 164

Mary, St., church of, at Clairvaux, $128,129,130$

at Limerick, xxx, xliv

at Mellifont, $75 \mathrm{f}$.

at Melrose, 69

monastery of, at Louth, 67

Matilda, empress, 76, I2I

-_, wife of David I., 69,76

-, wife of Henry 1., 76

-, wife of Stephen, 76

Mattock, stream, 75
Maurice, St., in Valois, 30

Maxwell, Sir IIerbert, $7 \delta$

Meath, xl, 40

bishops of: see O'Dunan, Rochfort, Tachmon. deaneries of, xxvii, li dioceses of, Exxvi--xxix, xxxiii, xlviii-lii

Mellifont Abbey, 75, 170 choice of site of, 75, I $3^{2}$ consecration of church of, 59, 75 daughters of, 76 progress of, 75, I35

Melrose, 69

Membra (memrae), 60

Memoria Sanctorum, 60

"Metropolitan," 36, 45, I66

Michael, abbot at Soulseat, 34 I 20

Michael's Church, St., 78

Mitre of St. Malachy, 73

Mochrum, 78

Mochuta, St., xlvii, I9

Molua, 28

Monaghan, county of, xli, lix

Monasteries rebuilt, 170

Monasternenagh, 76

Monenna, St., Life of, 32

Monk, nations which have not seen a, 74

Moore, Sir Edward, 75 f.

Moriarty, Nehemiah, bishop of Cloyne, lxi, 89

Mortlach, 28

Muiredach Mac Robartaigh (Marianus Scotus), xviii

Mullingar, diocese of, li

Mungret, 6

Munster, $\mathrm{xl}, 46,9 \mathrm{I}$ visitations of, xxxiv, xxxvi, $14,16,53,167,168,169$

Nurtough, coarb of Patrick, 43 . $46,50,51,164,165$ f., 167 , 170

“Nations," 74

Nehemiah, bishop of Cloyne, lxi, 89

Nemheds, I70 
Newbald, 68

Newtown, near Trim, xxvii, li synod at, xxvii, xxviii

Newtown Stewart, xli

Niall, coarb of Patrick, 43, 50, $53,58,167$, I 68 , I70, I 7 I

Nostal, priory of St. Oswald at, 69

O'boyle, Caincomrac, bishop of Armagh, xxxiv

Cinaeth, bishop of Clogher, lix, 66

O'Brien, xxvi

Conor, ling of Thomond, lv, lvi f., $21,23,43$ f., 5 I, I 70

Dermot, xxiv, 43

Murtough, kingr of Munster, xxiv, xxx, xxxv, xxxviii, $1 \mathrm{v}, 43$

Teague, I06

Turlough, xxiii, xxiv

O'Carroll, Donough, king of Oriel, lvii, lix, 58 f., 66,67 , $75, \mathrm{I}_{3}$, I $70 \mathrm{f}$.

O'Conor, Cathal, 106

Rory, 106

Turlough, king of Connaught, lv, 21, 23, 43, 106

O'Dunan, Mael Muire, "bishop of Meath," bishop of Clonard (?), xxiv, xxv, xxvi, xxix, xxxv, xxxvii, xxxviii, xlix

O'Flaherty, Donnell, 106

O'Gormon, Oengus, coarb of Comgall, 27

O'Ilagan, sept of, $5 \mathrm{I}$ f.

Imar, abbot of SS. Paul and Peter, Armagh, lii, liii, I I, I 3, I 5, 20, 26, 3I, 33, 36

O'Ilanley, Donough, bishop of Dublin, $x x, x x i$, xxiv Samuel, bishop of Dublin, $\mathrm{xx}, \mathrm{xxi}, \mathrm{xxiv}, \mathrm{xlvi}, 20$

O'Hanlon, sept of, 166 Rev. J., 78

O'Hanratty, family of, 7,27 Murtough, coarb of Com. gall, 27

O'Heney, Donnell, xxiii, xxiv
Oirgialla, the, 59, 166

O'Kane, xliv

O'Kelly, Edan, bishop of Louth, lix f., 1xii, 66

Old Melrose, 69

O'Loughlin, Conor, king of north of Ireland, $1 v, 40,46$, 55,59, I 70

1)onnell, 40

O'Morgair, sometimes written

O'Mongair, 6

family of, known as O'Dorherty, 7

Christian, bishop of Clogher and Louth, lix, $66,67,89,167$

Dermot, 6

Mughron, fer légind at Armagh, 6

See also Nalachy, St.

O'Neills, 5I, I66

Oratories, materials of, 32 f., I09

Oratory at Bangor, 30, 32, 109I 3

at Cairngarroch, 79, I 7 I

at Clairvaux, I2S, I 29

at Sanl, I 13

Oriel, Iviii, 59, I6 3, I 70

cathedral of, 67

diocese of, lviii-Ix, 67, I70

kings of: see $\mathrm{O}^{\prime}$ Carroll,

O'Loughlin see of, lix $f$.

O'Rorke, Tighernan, 59

Oswald, St., priory of, 69

O'Too!e, St. Laurence, archbishop of Dublin, xxi

Paisley, 29

Pall, xxxii, lxf., lxii-lxiv, 65,

73 , II 7 , IIS

Papal schism, 66, 72

Paparo, John, cardinal priest of St. Laurence, $\mathrm{xx}$ vii, $\mathrm{xlv}$, "lxii-lxiv

"Parish," meaning of, xxviii

Pastoral staves, 44, 49, 50, I 23 Patrick, St., 27, 89, I I 7 , I 4 , I62 
Patrick, St.-

authority of coarbs of, it

burial place of, 44, I I5, 117

canon of, 54

coarbs of : see Armagh, ablots of, archbishops of gospels of, 53,54

Patrick, bishop of Iullin, xx, xxi, xxiii, xlvi

- bishop of Limerick, xxi, 73

Paul and Peter, SS., monastery of, at Armagh, II, IS at Knock, 67, i I $\$$, 70

Penance, 37, 97, 9S, I15, I6I, I67

Peter, St., coarb of, i IS

Petit, Adam, archdeacon of Kells, xxviii

I'etric on stone churches, 32

Philip of Clairvaux, I3

Pilgrims from Connaught, 93

"P'oor man," 93

Popes: sie Jugenius, Gregory, ILonorius, Innocent, Lucius

Portus Lapasperi, $7 \mathrm{~S} \mathrm{f}$.

P'rimate of Ireland, xxxviif.

Princeps, 27

"(Quasi-generations," 45, 65

Ralph, archbishop of Canterbury, xxii, xlvi

Raphoe, diocese of, xli, xlii, lviii

Rathbreasail, synod of, xxxviilii, Ivi, Iviii, lix, I4, IS, 36, $47,62,65$; canons of, violated, lii, lviii, lx, lxi, lxii

Rathbrennan, 106

Rathluraigh, 44

Ratisbon, nionastery of St. Peter at, xviii

Rebekah, I33f.

Reformation of Irish Church, took place in twelfth century, $\mathrm{xii}$

causes of, $x v i-x x, x x v i$ scope of, xiii

"Returning to his own country," 127
Rheims, council of, 12 I

Kibble, river, $67,12 \mathrm{I}$

Ribchester, I I I

Ricemarch, son of Sulien, life of St. David by, xviii psalter of, $x$ vii $f$. verses of, xviii

Richard, abbot of Nelrose, 69

Rievaulx, 69

Rivulet becomes a river, 105 f., 154

Robert, architect of Mellifont, 75, I 36

Rochfort, Simon, bishop of Meath, xxvii, xxviii, 1

Roe Valley, xliv

Rosemarkie, 28

Rouen, 47

"Rouncy," 69

Round 'Towers, I 70

Route of St. Nalachy's journeys, $67,70,121$

Roxburgl, 76

Rutinus, I 45

Rummun, 33

Runcinus, 69

Sacraments, IS, 25 f., 39, 96, 97 , IOI, II 4 , II 7

"Sacraments" meaning the Eu. charist, I I4

St. Liz, Simon de, Earl of Northampton, 69, 76

Saul, 44, 87

monastery of 113,163

Scotia, 20

Scotic, 32

Scotland, 34, 67, 69, 72, 76, I 20 boundaries of, 67

Scotland, Further, I25

Scots. 20, 69, I Io

"Seed" of a bishop, 67, I65

Senior, $x x v, 4 S$

Sexual morality, xxiv, I62 f.

Shalvey, Donnell, erenach of Cork, 93

Sheelan, Lough, 59

Shrule, 76

Sigeric, archbishop of Canterbury, 70 
Sighere, 68

Silence, rule of, I 3

Sinach, I65

Singing, 17f., 37, 125, 127, 143, I6I

Sitric, king of Dublin, xix

Skerries, lxi, i 8

Skreen, diocese of, xxvii, 1

Sollemnitas, 126

Song, Church, 17f., 37, 125,

$127,143,161$

Soulseat, monastery founded at,

by St. Malachy, 34, I 20

Præmonstratensian monastery at, 120

Slanc, diocese of, xxvii, 1

Staff of Jesus, 53 f., 58,167, I68, I 69

keeper of, $5 \$, \mathbf{I} 67$

Staff sent by St. Malachy to St. Bernard, $13 \mathrm{I}$

Standard, Battle of the, 77

State of Continental Church described, I-3

State of the Irish Church described, I6-I8, 37 f., 45 f., I6I-3

Stephen, king of England, lxii, I 2 I, 142

Stone churches, II, 32 f., Io9

Stoneykirk, 78

Stowe Missal, I62

Students, in Irish schools, xiv, xvii f., xxvi

Suffragan, meaning of, xxii

Sulien the Wise, bishop of St. David's, xvii, xviii

Surio, De (Suir, monastery of the; Suriense monasterium), 4,76, I I 4

Sweden, 74

Sycarus (Sighere), 68

Tachmon, Hugh de, bishop of Meath, li

Tanaidhe, coarb of Comgall, 30

Tees, River, 67

Termonfeckin, $\mathbf{I} 70$

Tescelin, father of St. Bernarcl, 71
Thaddaeus, bishop of Kells, xxviii

Theobald, archbishop of Canterbury, 73, I 2 I

Thomas, St., monastery of, in Dublin, 1

Thomond, kingdom of, 43

Tír Conaill, lviii

Tiree, island of, 29

Tír Eoghain, lxviii

diocese of, 64

visitation of, xxxiv, 50

Tithes, xxxiii, 37, $84,163,170$

Tobit, I 5

Tostius, bishop of Waterford, $\mathrm{xxi}$

Translation of bodies to new cemetery at Clairvaux, I25, 143

Travellers from Ireland, xviii f., xxi, xxvi

Treasure found, 112

Tribal territories, xlii-xliv

Trim, diocese of, xxvii, 1

Tuam, archbishopric of, 1xiii

Tullaghoge, 5I, I 67 f., I 69

Turgesius, bishop of Limerick, xxi

Ua Condoirche: see Christian

Ua hAinmire: see Malchus

Ua Maelsechlainn Murrough, king of Meath, Io6

Ua Muidhin, Gilla Aedha, bishop of Cork, 1xi, 93

Ua Sinaich, I 66

Flann, 5 , 167

Uhtred, bishop of Llandaff, 73

Ui Méith, 27

Ui Neill, 40

Ui Sinaich, 165

Ulaid, lviii, $28,40,87$

count of, 89

diocese of, lviii, 64

duke and magnates of, II I

Ulster, $x l$ f., xlii, lviii, 46

Unction of sick, S8, $96 \mathrm{f} ., 124$ not confined to priests, I 64

Usnagh, synod of, xxviii, xlix, if. 
Valerian, persecution of, I4

Valle Salutis, De, 76

Vallis Angelorum, 27

Victor IV., anti-pope, 72

Viride Stagnum, I2O

Voice of the turtle, 3

Waltheof (Waldeve, Wallenus, Vallevus), St., abbot of Melrose, 69, I 21 69

Wardon, 69

Waterford, xix bishops of : sec Malchus, Tostius

diocese of, xix, xlvi
Watling Street, I 2 I

Wexford, xix

- diocese of, $x i x$

- or Ferns, diocese of, xlvii

William the Conqueror, 47

- I., king of Scots, 77

- , prior of Kirkham, 69

Winchester, I8, 19

Wissant, 70, 123

Wooden churches, $32 \mathrm{f}$.

Wormwood, Valley of, 7 I

Yellow Book of Lecan, 171

York, xxii, xxxix, 67, 68, 70

Zaccheus, II 4 





\section{PUBLICATIONS}

OF THE

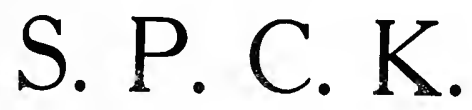

\section{BOOKS FOR}

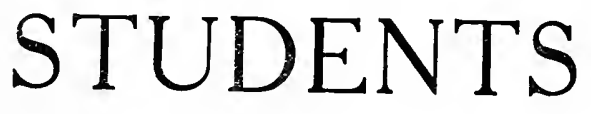

\section{AND}

OTHERS

SOCIETY FOR PROMOTING

CHRISTIAN KNOWLEDGE

LONDON: Central Offices: 6 ST. MARTIN'S Place, W.C. 2

Book Shops: 64 New Bond STreet, W. I

43 Queen Victoria Street, E.C. 4 And of all Booksellers.

New York: The Macmillan Company 


\section{BOOKS FOR STUDENTS}

\section{Translations of Early Documents}

A Series of texts important for the study of Christian origins. Under the Joint Editorship of the Rev. W. O. E. Oesterley, D.D., and the Rev. Canon G. H. Box, M.A.

The object of this Series is to provide short, cheap, and handy textbooks for students, either working by themselves or in classes. The aim is to fumish in translations important texts unencumbered by commentary or elaborate notes, which can be had in larger works.

\section{EXTRACTS FROM PRESS NOTICES.}

The Times Literary Supplement says: "These Jewish Apocalypses have a direct relation to the thought and religious ideals which confronted primitive Christianity in Palestine, and not only for their own sakes, but for their influence on the New Testament and Apostolic Christianity they deserve careful attention. Handbooks at once so scholarly and so readable will be welcomed by all interested in Christian origins."

The Church Quarterly Review say's: "To the theological student who is anxious to know something of the circumstances and thought of the time during which Christianity grew up, and of the Jewish environment of the teaching of our Lord and the Apostles, there is no class of books more valuable than the later Jewish Apocrypha."

The Church Times says: "The names of the Editors are a guarantee of trustworthy and expert scholarship, and their work has been admirably pertormed."

The Tablet says: "A valuable series . . well brought out and should prove useful to students."

Catholic Book Notes says: "The S.P.C.K. is to be congratulated on its various series of cheap and useful books for students."

The Journal of the Society of Oriental Research (U.S.A.) says : "The S.P.C.K. have again made the whole body of students, interested in things Jewish and Early Christian, their debtors ... their splendid work in this series."

The Living Church (U.S.A.) says: "To praise this project too highly is an impossibility. Everyone has felt the need of such a series of handy and inexpensive translations of these documents and . . . we are assured of excellent results." 


\section{Translations of Early Documents}

\section{FIRST SERIES - Palestinian=Jewish and Cognate Texts (Pre=Rabbinic)}

1. Jewish Documents of the Time of Ezra Translated from the Aramaic by A. E. Cowley, Litt.D., Sub-Librarian of the Bodleian Library, Oxford. 4s. $6 d$. net.

2. The Wisdom of Ben-Sira (Ecclesiasticus) By the Rev. W. O. E. Oesterley, D.D., Vicar of St. Alban's, Bedford Park, W.; Examining Chaplain to the Bishop of London. $3 s .6 d$. net.

3. The Book of Enoch

By the Rev. R. H. Charles, D.D., Canon of Westminster. $3 s .6 d$. net.

4. The Book of Jubilees

By the Rev. Canon Charles. 4s. 6d. net.

5. The Testaments of the Twelve Patriarchs By the Rev. Canon Charles. 3s. $6 d$. net.

6. The Odes and Psalms of Solomon

By the Rev. G. H. Box, M.A., Rector of Sutton, Beds., Hon. Canon of St. Albans.

7. The Ascension of Isaiah

By the Rev. Canon Charles. Together with No. Io in one volume. $4 s .6 d$. net.

8. The Apocalypse of Ezra (ii. Esdras)

By the Rev. Canon Box. 3s. $6 d$. net.

9. The Apocalypse of Baruch

By the Rev. Canon Charles. Together with No. I 2 in one volume. $3 s .6 d$. net. 


\section{Translations of Early Documents (continued)}

10. The Apocalypse of Abraham

By the Rev. Canon Box. Together with No. 7 in one volume. $4 s .6 d$. net.

11. The Testaments of Abraham, Isaac and Jacob

By the Rev. Canon Box and S. Gaselee.

12. The Assumption of Moses

By Rev. W. J. Ferrar, M.A., Vicar of Holy Trinity, East Finchley. With No. 9 in one volume. 3 s. $6 d$. net.

13. The Biblical Antiquities of Philo

By M. R. James, Litt.D., F.B.A., Hon. Litt.D., Dublin, Hon. LL.D., St. Andrews, Provost of King's College, Cambridge. $8 s .6 d$. net.

14. The Lost Apocrypha of the Old Testament By M. R. James, Litt.D. $5^{s .6}$. 6 . net.

\section{SECOND SERIES - Hellenistic=Jewish Texts}

1. The Wisdom of Solomon

By W. O. E. Oesterley, D.D. $3 s .6 d$. net.

2. The Sibylline Oracles (Books iii-v)

By the Rev. H. N. Bate, M.A., Vicar of Christ Church, Lancaster Gate, W. ; Examining Chaplain to the Bishop of London. $3 s$. $6 d$. net.

3. The Letter of Aristeas

By H. St. John Thackeray, M.A., King's College, Cambridge. $3 s .6 d$. net.

4. Selections from Philo

5. Selections from Josephus

By H. St. J. Thackeray, M.A. 5s. net. 


\section{Translations of Early Documents (continued)}

\section{The Third and Fourth Books of Maccabees}

By the Rev. C. W. Emmet, B.D., Vicar of West Hendred, Berks. 3s. 6 d. net.

7. The Book of Joseph and Asenath

Translated from the Greek text by E. W. Brooks. 3s. $6 d$. net.

\section{THIRD SERIES - Palestinian=Jewish and}

\section{Cognate Texts (Rabbinic)}

*1. The Sayings of the Jewish Fathers (Pirke Aboth). Translated from the Hebrew by W. O.E. Oesterley, D.D. 5s. net.

*2. Berakhoth. By the Rev. A. Lukyn Williams, D.D.

*3. Yoma. By the Rev. Canon Box.

*4. Shabbath. By W. O. E. Oesterley, D.D.

*5. Tractate Sanhedrin. Mishnah and Tosefta. The Judicial procedure of the Jews as codified towards the end of the second century A.D. Translated from the Hebrew, with brief Annotations, by the Rev. Herbert Danby, M.A., Sub-Warden of St. Deiniol's Library, Hawarden. 6s. net.

[The special importance of this consists in the light thrown by it on the trial of our Lord.]

*6. Kimhi's Commentary on the Psalms (Book I, Selections). By the Rev. R. G. Finch, B.D. 7 s. $6 d$. net.

7. Tamid

8. Aboda Zara

9. Middoth

10. Sopherim
11. Megilla

12. Sukka

13. Taanith

14. Megillath Taanith

* It is proposed to publish these texts first by way of experiment. If the Series should so far prove successful the others will follow. Nos. I, 5 and 6 are now ready. 


\section{Translations of Early Documents (continued)}

\section{Jewish Literature and Christian Origins :}

Vol. I. The Apocalyptic Literature.

,, II. A Short Survey of the Literature of Rabbinical and Mediæval Judaism.

By W. O. E. Oesterley, M.A., D.D., and G. H. Box, M.A., D.D.

\section{The Uncanonical Jewish Books}

A Short Introduction to the Apocrypha and the Jewish Writings 200 B.C.-A.D. I00. By William JOHN FERRAR, M.A., Vicar of East Finchley. 3s. net.

A popularisation of the work of specialists upon these books, which have attracted so much attention.

\section{Translations of Christian Literature}

General Editors :

W. J. SPARROW SIMPSON, D.D.; W. K. LOWTHER CLARKE, B.D.

A NUMBER of translations from the Fathers have already been published by the S.P.C.K. under the title "Early Church Classics." It is now proposed to enlarge this series to include texts which are neither "early" nor necessarily "classics." The divisions at present proposed are given below. Volumes belonging to the original series are marked with an asterisk.

The Month says: "The cheap and useful series."

The Church Times says: "The splendid series."

Studies says: "For the intelligent student of Church history who cannot afford to be a specialist ... such books abound in information and suggestion."

\section{SERIES I.-GREEK TEXTS.}

Dionysius the Areopagite: The Divine Names and the Mystical Theology. By C. E. Rolt. 7s. 6d. net.

The Library of Photius. By J. H. Freese, M.A. In 6 Vols. Vol. I. ros. net. 


\section{Translations of Christian Literature (continued)}

\section{SERIES I.-GREEK TEXTS (continued).}

The Apocriticus of Macarius Magnes. By T. IV. Crafer, D.D. $7 s$. $6 d$. net.

*The Epistle of St. Clement, Bishop of Rome. By the Rt. Rev. J. A. F. GregG, D.D. Is. $6 d$. net.

*Clement of Alexandria: Who is the Rich Man that is being saved? By P. M. BARNARD, B.D. Is. $6 d$. net. ${ }^{*}$ St. Chrysostom: On the Priesthood. By T. A. Moxon. $2 s$. net.

The Doctrine of the Twelve Apostles. By C. BIGG, D.D. Revised by the Right Rev. A. J. Maclean, D.D. *The Epistle to Diognetus. By the Rt. Rev. L. B. RADFORD, D.D. Is. $6 d$. net.

St. Dionysius of Alexandria. By C. L. Feltoe, D.D. 3 s. 6 d. net.

*The Epistle of the Gallican Churches: Lugdunum and Vienna. With an Appendix containing Tertullian's Address to Martyrs and the Passion of St. Perpetua. By T. H. Bindley, D.D. is. $6 d$. net.

* St. Gregory of Nyssa: The Catechetical Oration. By the Ven. J. H. SRawley, D.D. 2s. net.

${ }^{*}$ St. Gregery of Nyssa: The Life of St. Macrina. By W. K. Lowther Clarke, B.D. is. $6 d$. net.

Gregory Thaumaturgus (Origen the Teacher): the Address of Gregory to Origen, with Origen's Letter to Gregory. By W. Metcalfe, B.D. [Re-issue. *The Shepherd of Hermas. By C. TAYLOR, D.D. 2 vols. $2 s$. each net.

Eusebius: The Proof of the Gospel. By W. J. Ferrar, 2 vols.

Hippolytus: Philosophumena. By F. LEGGE. 2 vols.

The Epistles of St. ignatius. By the Ven. J. H. SRAwLeY, D.D. is. net. 
Translations of Christian Literature (continued)

SERIES I.-GREEK TEXTS (continued).

*St. Irenaeus: Against the Heresies. By F. R. M. Hiтснсоск, D.D. 2 vols. $2 s$, each net.

Palladius: The Lausiac History. By W. K. LowtheR CI.ARKE, B.D. 5s. net.

Palladius: The Life of St. Chrysostom. By H. Moore. *St. Polycarp. By B. Jackson. is. 6d. net.

St. Macarius: Fifty Spiritual Homilies. By A. J. MASON, D.D.

\section{SERIES II.--LATIN TEXTS.}

Tertullian's Treatises concerning Prayer, concerning Baptism. By A. Souter, D.Litt. 3 s. net.

Tertullian against Praxeas. By A. SoUTER, D.Litt. 5s. net.

Novatian on the Trinity. By H. Moore. 6s, net. ${ }^{*}$ St. Augustine: The City of God. By F. R. M. Hitchсоск, D.D. Is. $6 d$. net.

*St. Cyprian: The Lord's Prayer. By T. H. Bindley, D.D. $1 s, 6 d$. net.

Minucius Felix: The Octavius. By J. H. FreEse. 3s. $6 d$. net.

*Tertullian: On the Testimony of the Soul and On the Prescription of Heretics. By T. H. BindLeY, D.D. $2 s$, net.

* St. Vincent of Lerins: The Commonitory. By T. H. Bindeey, D.D. $2 s$. net.

St. Bernard: On Grace and Free Will. By W. Watkin Williams.

\section{SERIES III.-LITURGICAL TEXTS.}

\section{Edited By C. L. FELTOE, D.D.}

St. Ambrose: On the Mysteries and on the Sacra= ments. By T. Thompson, B.D., and J. H. SRawLey, D.D. $4 s .6 d$. net. 


\section{Translations of Christian Literature (continued)}

\section{SERIES III.-LITURGICAL TEXTS (continued).}

*The Apostolic Constitution and Cognate Documents, with special reference to their Liturgical elements. By De Lacy O'Leary, D.D. is. $6 d$. net.

*The Liturgy of the Eighth Book of the Apostolic Constitution, commonly called the Clementine Liturgy. By R. H. Cresswell. is. $6 d$. net.

The Pilgrimage of Etheria. By M. L. McClure. 6s. net. *Bishop Sarapion's Prayer $=$ Book. By the Rt. Rev. J. WORDSWORTH, D.D. Is. $6 d$. net.

The Swedish Rite. Vol. I, by E. E. Yelverton. Vol. II, by J. H. Swinstead, D.D.

\section{SERIES IV.-ORIENTAL TEXTS.}

The Ethiopic Didascalia. By J. M. Harden, B.D., LL.D. 9s. net.

The Apostolic Preaching of Irenaeus (Armenian). By J. A. Robinson, D.D.

\section{SERIES V.-LIVES OF THE CELTIC SAINTS.} EDITED bY ELEANOR HULL.

St. Malachy of Armagh (St. Bernard). By H. J. LAWLOR, D.D.

St. Ciaran of Clonmacnois. By R. A. S. Macalister. St. Patrick: Life and Works. By N. D. J. White, D.D.

\section{SERIES VI.-SELECT PASSAGES.}

Documents Illustrative of the History of the Church. Vol. I. To A.D. 313. Edited by B. J. KIDD, D.D. 7 s. $6 d$. net.

SERIES VII.-MODERN EUROPEAN LANGUAGES. Lives of the Serbian Saints. By C. P. Hankey. 


\section{Handbooks of Christian Literature}

The Letters of St. Augustine. By the Rev. Canon W. J. Sparrow Simpson, D.D. Cloth boards, ios. net.

The Early Christian Books. A Short Introduction to Christian Literature to the Middle of the Second Century. By W. John Ferrar, M.A., Vicar of East Finchley. Cloth boards, $3 s$. $6 \mathrm{~d}$. net.

The Inspiration and Authority of Holy Scripture. A Study in the Literature of the First Five Centuries. By George Duncan Barry, B.D. Cloth boards, 4s. $6 d$. net.

The Eucharistic Office of the Book of Common Prayer. By the Rev. Leslie WRight, M.A., B.D. Cloth boards, $3 s$. 6 d. net.

\section{Helps for Students of History}

Edited by

C. JOHNSON, M.A., H. W. V. TEMPERLEY, M.A. and J. P. WHITNEY, D.D., D.C.L.

I. Episcopal Registers of England and Wales. By R. C. Fowler, B.A., F.S.A. 6d. net.

2. Municipal Records. By F. J. C. Hearnshaw, M.A. $6 d$. net.

3. Medieval Reckonings of Time. By Reginald L. Poole, LL.D., Litt.D. $6 d$. net.

4. The Public Record Office. By C. Johnson, M.A. 6d. net.

5. The Care of Documents. By C. Johnson, M.A. $6 d$. net.

6. The Logic of History. By C. G. Crump. 8d. net.

7. Documents in the Public Record Office, Dublin. By R. H. Murray, Litt.D. Sd. net.

8. The French Wars of Religion. By Arthur A. Tilley, M.A. $6 d$. net. 
Helps for Siudents of History (continued).

By Sir A. W. WARD, Litt.D., F.B.A.

9. The Period of Congresses-I. Introductory. $8 d$. net.

10. The Period of Congresses-II. Vienna and the Second Peace of Paris. Is. net.

II. The Period of Congresses-III. Aix $=\mathbf{l a}=$ Chapelle to Verona. is. net.

Nos. 9, I0, and II in one volume, cloth, $3^{s .} 6 d$. net.

12. Securities of Peace: A Retrospect (1848-1914). Paper, 2s. net; cloth, 3 s. net.

13. The French Renaissance. By A. A. Tilley, M.A. $8 d$. net.

14. Hints on the Study of English Economic History. By W. Cunningham, D.D., F.B.A., F.S.A. 8d. net.

15. Parish History and Records. By A. Hamilton Thompson, M.A., F.S.A. $8 d$. net.

16. A Short Introduction to the Study of Colonial History. By A. P. Newton, M.A., D.Litt. 6d. net.

17. The Wanderings and Homes of Manuscripts. By M. R. James, Litt.D., F.B.A. Paper cover, 2s.; cloth boards, 3 s. net.

I8. Ecclesiastical Records. By the Rev. Cladde Jenkins, MI.A., Librarian of Lambeth Palace.

19. An Introduction to the History of American Diplomacy. By Carl Russell Fish, Ph.D., Professor of American History in the University of Wisconsin. Is. net.

20. Hints on Translation from Latin into English. By Alexander Souter, D.Litt. $6 d$. net. 
Helps for Students of History (continued).

21. Hints on the Study of Latin (A.D. 125-750). By Alexander Souter, D.Litt. $8 d$. net.

22. Report of the Historical MSS. Commission. By R. A. Roberts, F.R.Hist.S., sometime Secretary of the Commission.

23. A Guide to Franciscan Studies. By A. G. Litrle.

24. A Guide to the History of Education. By JoHN William Adamson, Professor of Education in the University of London. $8 d$. net.

25. Introduction to the Study of Russian History. By W. F. Reddaway. $6 d$. net.

26. Monuments of English Municipal Life. By W. Cunningham, D.D., F.B.A.

27. La Guyenne Pendant la Domination Anglaise, $1152=1453$. Esquisse d'une Bibliographie Méthodique par Charles Bémont.

28. The Historical Criticism of Documents. By R. L. Marshall, M.A., LL.D.

29. The French Revolution. By G. P. Gooch.

30. Seals. By H. S. Kingsford.

\section{The Story of the English Towns}

A Series of Popular but Scholarly Histories of English Towns, designed primarily for the general reader, but suitable also for use in schools. With Maps, Plans, and Illustrations. Cloth boards. $4 s$. net.

The Yorkshire Post says: "A picturesque history of Yorkshire's two leading cities."

The Times Literary Supplement says : "This well-planned series." Leeds. By J. S. Fletcher, Member of the Yorkshire Archæological Society.

Peterborough. By K. and R. E. ROBERTS. 
The Story of the English Towns (continued). Sheffield. By J. S. FLETCHER.

Westminster. By H. F. Westlake, M.A., F.S.A., Custodian and Minor Canon of Westminster Abbey.

In the Press-

Harrogate Birmingham Nottingham

Pontefract Halifax Plymouth

St. Albans, etc.

\section{Studies in Church History}

The Venerable Bede. His Life and Writings. By the Right Rev. G. F. Browne, D.D., formerly Bishop of Stepney and of Bristol. With Illustrations. Cloth boards, los. net.

The Morning Post says: "The final and complete history of the scholar-saint."

The Reformation in Ireland. A Study of Ecclesiastical Legislation. By Henry Holloway, M.A., B.D. Cloth boards, $7 s .6 d$. net.

[Study of the Irish Reformation is essential, if English readers are to understand present-day. Irish problems, which hinge largely on religious questions. The author discusses his difficult subject with complete impartiality.]

The Universe says: "The standpoint from which he writes is that of the detached and unbiassed historian. His book is refreshingly satisfactory."

The Emperor Julian. An Essay on His Relations with the Christian Religion. By EDWARD J. Martin, B.D., formerly Scholar of Oriel College, Oxford. Cloth boards, 3 s. $6 d$. net.

The Importance of Women in Anglo-Saxon Times; The Cultus of St. Peter and St. Paul, and other Addresses. By the Right Rev. G. F. Browne, D.D. With two Illustrations. Cloth boards, $7 s$. $6 d$. net.

The Guardian says: "Deserves to be widely read both for the excellent choice of its matter and the equally admirable presentation of it." 


\section{Studies in Church History (continued).}

Essays Liturgical and Historical. By J. WICKHAM LEGG,

D.Litt., F.S.A. Cloth boards, 55 s. net.

The English Historical Review says: "Scholars and antiquaries will thank Dr. Legg for the service he has done by making these studies more widely known."

French Catholics in the Nineteenth Century. By the Rev. Canon IW. J. Sparrow Simpson, D.D. Cloth boards, 5s. net.

The Expository Times says: "The book has the merits of good history and good biography, both in manifest excellence."

An Abbot of Vézelay. By Rose Graham, F.R.Hist.S.

With eight Illustrations. Cloth boards, $3 s .6 d$. net.

iz. The Westminster Gazette says: "His career bristles with interdicts, excommunications, appeals to Rome, and struggles in which he showed himself to be very distinctly a member of the Church Militant."

\section{Texts for Students}

General Editors : CAROLINE A. J. SKEEL, D.Lit.; H. J WHITE, D.D.; J. P. WHITNEY, D.D., D.C.L.

r. Select Passages from Josephus, Tacitus, Suetonius, Dio Cassius, illustrative of Christianity in the First Century. Arranged by H. J. White, D.D. Paper cover, $3^{d}$. net.

2. Selections from Matthew Paris. By C. A. J. Skeel, D.Lit. Paper cover, $9 d$. net.

3. Selections from Giraldus Cambrensis. By C. A. J. SkEEL, D.Lit. Paper cover, $9 d$. net.

4. Libri Sancti Patricii. The Latin Writings of St. Patrick, etc. Edited by Newport J. D. White, D.D. Paper cover, $6 d$. net.

5. A Translation of the Latin Writings of St. Patrick. By Newport J. D. White, D.D. Paper cover, $6 d$. net.

6. Selections from the Vulgate. Paper cover, $9 d$. net.

7. The Epistle of St. Clement of Rome. Paper corer, $6 d$. net. 


\section{Texts for Students (continued).}

S. Select Extracts from Chronicles and Records re= lating to English Towns in the Middle Ages. Edited, with Introduction, Notes, and Glossary, by F. J. C. Hearnshaw, M.A., LL. D. Paper cover, $9 d$. net.

9. The Inscription on the Stele of Méša. Commonly called the Moabite Stone. The text in Moabite and Hebrew, with translation by the Rev. H. F. B, Compston, M.A. Paper cover, $6 d$. net.

10. The Epistles of St. 1gnatius. Edited by T. W. Crafer, D.D. is. net.

II. Christian Inscriptions. By H. P. V. Nunn, M.A. With two Illustrations. Is. net.

I 2 Selections from the "Historia Rerum Anglicarum" of William of Newburgh. i $s . s^{d}$. net.

I3. The Teaching of the Twelve Apostles. By T. IV. Crafer, D.D. $4 d$. net.

14. The Epistle of Barnabas. Edited by T. W. Crafer, D.D. $6 d$. net.

I5. The Code of Hammurabi. By Percy Handcock, M.A. Is. net.

16. Selections from the Tell El=Amarna Letters. By Percy Handcock, M.A. 4d. net.

I 7. Select Passages lliustrating Commercial and Diplomatic Relations between England and Russia. By A. Wenner, M.A., F.R.Hist.S. is, $6 d$. net.

Itinerarium Regis Ricardi. By M. T. STEAD.

Select Extracts Illustrating Florentine Life in the Thirteenth and Fourteenth Centuries. By E. G. ROPER.

Select Extracts Illustrating Florentine Life in the Fifteenth Century. By Esther G. Roper.

Slavonic Settlements in Dalmatia, Croatia and Serbia. By J. B. Burv, F.B.A.

Babylonian Flood Stories. By Percy Handcock, M.A. Babylonian Penitential Psalms. By Percy Handcock, M.A.

Documents Illustrating Irish History in the Sixteenth Century. 4 Vols. By Constance Maxwell. 


\section{Pioneers of Progress}

MEN OF SCIENCE : Edited by S. Chapman, M.A., D.Sc.

Each with a Portrait. Paper cover, 1s. ; cloth, 2s. net.

The Medical Times says: "Extremely well written and should do much to stimulate interest in science ... especially suitable to place in the hands of senior school-boys and junior students."

Galileo. By W. W. Bryant, F.R.A.S., Royal Observatory, Greenwich.

Michael Faraday. By J. A. Crowther, D.Sc.

Alfred Russel Wallace. The Story of a Great Dis= coverer. By Lancelot T. Hogben, B.A., B.Sc.

Joseph Priestley. By D. H. Peacock, B.A., M.Sc., F.I.C.

Joseph Dalton Hooker, O.M., G.C.S.I., C.B., F.R.S., M.D., etc. By Professor F. O. Bower, Sc.D., F.R.S.

Herschel. By the Rev. Hector Macpherson, M.A., F.R.A.S., F.R.S.E.

Archimedes. By Sir Thomas L. Heath, K.C.B., F.R.S.

Aristarchus of Samos. By Sir Thomas L. Heath, K.C.B., F.R S.

John Dalton. By L. J. Neville-Polley, B.Sc.

WOMEN : Edited by ETHel M. Barton. With Illustrations.

Florence Nightingale. By E. F. Hall.

Dorothea Beale. By Elizabeth H. Shillito, B.A.

Elsie Inglis. By Eva Shaw McLaren. 

. 


\section{PLEASE DO NOT REMOVE \\ CARDS OR SLIPS FROM THIS POCKET}

\section{UNIVERSITY OF TORONTO LIBRARY}

BX

4700

M34B5
Bernard de Clairvaux, Saint

Life of St. Malachy of Armagh 
